Cristina Emy Yokaichiya

\title{
A FINALIDADE DA PENA NOS CRIMES CONTRA O MEIO AMBIENTE
}

Dissertação de Mestrado

Orientador: Professor Titular Miguel Reale Júnior

Faculdade de Direito da Universidade de São Paulo

São Paulo

2011 
Cristina Emy Yokaichiya

\section{A FINALIDADE DA PENA NOS \\ CRIMES CONTRA O MEIO AMBIENTE}

Dissertação apresentada à Faculdade de Direito da USP, na área de concentração de Direito Penal, Medicina Forense e Criminologia para obtenção do título Mestre.

Orientador: Professor Titular Miguel

Reale Júnior

São Paulo

2011 


\section{A FINALIDADE DA PENA NOS CRIMES CONTRA O MEIO AMBIENTE}

Dissertação apresentada à Faculdade de Direito da USP, na área de concentração de Direito Penal, Medicina Forense e Criminologia para obtenção do título Mestre.

Orientador: Professor Titular Miguel Reale Júnior

Aprovada em:

Banca Examinadora

Prof. Dr.

Instituição

Assinatura

Prof. Dr.

Instituição

Assinatura

Prof. Dr.

Instituição

Assinatura 
À minha família, a mais bela representação de amor, apoio e compreensão.

E para você, Daniel, que mesmo longe em alguns momentos, esteve sempre presente. 
Agradezco la pobreza para que la pobreza no me maldiga y me conceda anillos que me distingan de cuando fui puro y legislaba en la negación.

Huelo los testimonios de cuanto es sucio sobre la tierra y no me reconcilio pero amo lo que ha quedado de nosotros. Estoy viejo de mí mismo pero hay estigmas. Han llegado los visitantes. Hay hormigas debajo de las llagas.

Siento la fertilidad que se refugia en la ira de mis cabellos y oigo el deslizamiento de las especies que nos han abandonado (...)

No recurriré a la verdad porque la verdad ha dicho no y ha puesto ácidos en mi cuerpo.

Descripción de la mentira de Antonio Gamoneda

Em que se baseia este poder não poucas vezes chamado de 'pretensão punitiva' ou de 'direito de punir'? Existem, e se existem, quais são as razões que tornam 'justo', ou 'justificável', ou 'aceitável moralmente e/ou politicamente' que, à violência ilegal representada pelo delito se agregue aquela segunda violência legal que é a pena? E como justificar o exercício de uma violência organizada que assiste à uma multidão de sujeitos contra um único individuo? (FERRAJOLI, 2006, p. 230). 


\section{AGRADECIMENTOS}

Neste período de pós-graduação aprendi que o principal crescimento acadêmico ocorre com o diálogo e o debate crítico. Por esse motivo, quero agradecer a todos aqueles que, de alguma forma, se dispuseram a comentar, questionar e debater o objeto deste estudo.

Agradeço em primeiro lugar ao professor Miguel Reale Júnior, que me orientou com maestria, e mais do que dirigir meus estudos, incentivou-me a ampliar conhecimentos e expandir horizontes no apaixonante mundo do Direito Penal.

Não posso deixar de manifestar a importância dos estudos realizados na Espanha, que só foram possíveis com o programa de becas para estudiantes no comunitários da $U P F$. Meus mais sinceros agradecimentos ao professor Jesús-María Silva Sánchez, que, como humanista e cientista do direito, guiou-me pelo vivo ambiente acadêmico na Facultad de Derecho de la Universidad Pompeu Fabra, onde tive a oportunidade de conviver, especialmente, com os notáveis professores Ricardo Robles Planas e Ramon Ragués i Vallès, que teceram valiosos comentários a respeito do tema deste mestrado.

Agradeço também à professora Mirentxu Corcoy Bidasolo, estudiosa crítica e inovadora no âmbito do Direito Penal ambiental, com quem tive estimulantes aulas e conversas na Universidad de Barcelona, no curso do Máster en Derecho penal e ciencias penales. E ao professor Luiz Grego, que, embora não me conheça pessoalmente, não hesitou em apresentar suas sinceras e profundas observações sobre os primeiros esboços deste trabalho.

À professora Helena Regina Lobo da Costa, de inequívoca vocação para a docência, agradeço as conversas marcadas pela delicadeza e pelo brilho. Sou grata pela compreensão, pela retidão, pelo entusiasmo e pela honestidade intelectual. Suas considerações e sugestões bibliográficas tiveram um valor inestimável.

À professora Ana Elisa Liberatore Silva Bechara, agradeço pelas sugestões enriquecedoras transmitidas durante meu exame de qualificação.

Sou grata à professora Maíra Rocha Machado, pelos admiráveis trabalhos empíricos desenvolvidos na área do Direito Penal, e por compartilhar sua experiência e capacidade analítica, particularmente importantes para que meu projeto de pesquisa germinasse. À professora Janaína Conceição Paschoal e ao professor Eduardo Reale 
Ferrari, agradeço pela paciência e estímulo nos primeiros passos de minha vida acadêmica, dos bancos da São Francisco à defesa da tese de láurea, e pelas animadas conversas que se seguiram.

Preciso mencionar meus amigos que participaram deste processo e contribuíram com seus conhecimentos, dedicação e apoio, especialmente Milene Cristina Santos, Júlia Tavares de Oliveira, Mariana Tranchesi Ortiz, Estela Waksberg Guerrini e Olga Pozas Presa. Mais que amigas, elas foram fiadoras de paciência e amor, tecelãs da minha confiança em que seria possível concretizar este trabalho.

Ao Daniel, obrigado por ser meu companheiro de todas as horas.

Não há palavras que expressem a gratidão que sinto por meus pais, Helena e Nelson, de quem demandei carinho, compreensão e apoio em doses extraordinariamente elevadas. Agradeço também a alegria de sempre de toda a família: Daniel, Alexandre, Ricardo, Gabriela, Diná, Helena, Glauco, Lucio, Victor e, no final desta jornada, o pequeno Vicente. 


\section{RESUMO}

O presente trabalho tem como objeto a análise da finalidade da pena nos crimes contra o meio ambiente. Pretendeu-se rediscutir as teorias das penas - que procuram atribuir à pena fins que legitimem sua existência e aplicação - à luz do Direito Penal ambiental, cujas peculiaridades na formação do injusto jurídico-penal produzem reflexos sobre essa legitimação no Estado democrático de Direito.

Para tanto, expôs-se criticamente as principais teorias das penas, que se ocuparam de definir os conceitos de retribuição e prevenção. A partir dessa base, as características do Direito Penal do meio ambiente foram confrontadas com as teorias das penas, tecendo-se considerações sobre o bem jurídico ambiental, os sujeitos destinatários das normas, a utilização da remissão administrativa, os delitos de perigo abstrato e a reparação do dano.

Diante desse panorama, demonstrou-se que as escolhas legislativas quanto à estrutura do injusto penal ambiental e às sanções dele decorrentes desencadeiam uma perda de conteúdo dos fins das penas conhecidos. Em outras palavras, parece haver um descompasso entre as teorias das penas e o Direito Penal, em especial na seara ambiental. No contexto de busca por uma finalidade da pena nos crimes contra o meio ambiente, verificou-se haver o reconhecimento doutrinário de uma função simbólica da sanção penal - para a construção de uma ética ambiental -, que não deveria prevalecer sobre os efeitos instrumentais da pena, sob risco de deterioração da credibilidade do Direito Penal, em face da ineficiência na resolução efetiva de conflitos.

Por fim, investigou-se, nas decisões dos tribunais superiores brasileiros, desde a vigência da Lei de Crimes Ambientais, a efetiva aplicação das penas no Direito Penal ambiental. O quadro resultante deste levantamento empírico, a nosso ver, confirma o diagnóstico de que o Direito Penal ambiental deveria ser restrito aos casos mais graves de degradação ambiental, convergente com a intervenção mínima e subsidiária. Aperfeiçoar as normas penais ambientais, com estruturas de imputação compatíveis com uma política criminal que valoriza os direitos fundamentais, parece ser a melhor alternativa para garantir, além do simbolismo, a prevalência dos fins manifestos da sanção penal.

Palavras-chave: Finalidade das penas. Crimes ambientais. Simbolismo. Supremo Tribunal Federal. Superior Tribunal de Justiça. 


\begin{abstract}
This work aimed to study the objectives of criminal punishments in environmental crimes. Theories on criminal punishments, which attempt to underpin the rightness and justification of criminal sanctions, were reexamined in light of environmental criminal law, whose idiosyncrasies with respect to the shape and form of criminal offenses echo on rule of law legitimacy processes.

In order to achieve such analysis, major theories on criminal punishments were critically assessed, as were the definitions of retribution and deterrence. This departure point allowed for the characteristics of environmental criminal law to be confronted with theories on criminal punishments, and as a result for the examination of environmental criminal law's object of protection, its subjects, the use of administrative guidelines, abstract endangerment crimes, and restoration.

Such analyses indicate that legislative choices with regard to the structure of environmental criminal offenses and their sanctions have diluted criminal punishments' objectives according to traditional theories. In other words, theories on criminal punishments seem not to be synchronized with factual criminal law, especially in the environmental field. Amidst the search for criminal punishments' objectives in environmental crimes, doctrinal studies have confirmed the existence of an objective symbolic communication - related to environmentalist ethics - for criminal punishments in crimes against the environment. Such function should not prevail to the detriment of criminal punishments' instrumental effects, because it could jeopardize criminal law's credibility, due to the lack of effective dispute resolution.

Finally, Brazilian superior courts' decisions since the enactment of the Environmental Crimes Law were studied to verify the actual application of criminal punishments related to the environment. This empirical work has, in our view, confirmed that environmental criminal law should be restricted to the most acute cases of environmental damages, in accordance with minimal and subsidiary interference by criminal law. Enhancing environmental criminal law, making its application convergent with a criminal policy that strengthens fundamental rights, seem to be the preferred path for ensuring, beyond symbolism, the explicit objectives of criminal punishments.
\end{abstract}

Keywords: Objectives of criminal punishments. Crimes against the environment. Symbolism. Supremo Tribunal Federal. Superior Tribunal de Justiça. 


\section{ABREVIATURAS}

\begin{tabular}{|c|c|}
\hline$\S$ & parágrafo \\
\hline AI & Agravo de Instrumento \\
\hline AM & Amazonas \\
\hline Art. & Artigo \\
\hline BA & Bahia \\
\hline $\mathrm{CF}$ & Constituição Federal \\
\hline Cf. & Confira \\
\hline $\mathrm{CP}$ & Código Penal \\
\hline d.j. & data de julgamento \\
\hline DF & Distrito Federal \\
\hline GO & Goiás \\
\hline $\mathrm{HC}$ & Habeas Corpus \\
\hline IBAMA & Instituto Brasileiro do Meio Ambiente e dos Recursos Naturais Renováveis \\
\hline INPE & Instituto Nacional de Pesquisas Espaciais \\
\hline J. & julgamento \\
\hline JECrims & Juizados Especiais Criminais \\
\hline $\mathrm{MG}$ & Minas Gerais \\
\hline MS & Mato Grosso do Sul \\
\hline MT & Mato Grosso \\
\hline n. & número \\
\hline ONU & Organização das Nações Unidas \\
\hline PA & Pará \\
\hline Par. & parágrafo \\
\hline PB & Paraíba \\
\hline PR & Paraná \\
\hline PRODES & Monitoramento da Floresta Amazônica Brasileira por Satélite \\
\hline QO & Questão de Ordem \\
\hline $\mathrm{RE}$ & Recurso Extraordinário \\
\hline RESP & Recurso Especial \\
\hline RJ & Rio de Janeiro \\
\hline $\mathrm{RN}$ & Rio Grande do Norte \\
\hline RO & Rondônia \\
\hline $\mathrm{RS}$ & Rio Grande do Sul \\
\hline $\mathrm{SC}$ & Santa Catarina \\
\hline SISPENAS & Sistema de Consulta sobre Crimes, Penas e Alternativas à Prisão \\
\hline SP & São Paulo \\
\hline STF & Supremo Tribunal Federal \\
\hline STJ & Superior Tribunal de Justiça \\
\hline TAC & Termo de Ajustamento de Conduta \\
\hline TJRS & Tribunal de Justiça do Rio Grande do Sul \\
\hline TJSC & Tribunal de Justiça de Santa Catarina \\
\hline TO & Tocantins \\
\hline TRF3 & Tribunal Regional Federal da $3^{\mathrm{a}}$ Região \\
\hline
\end{tabular}




\section{SUMÁRIO}

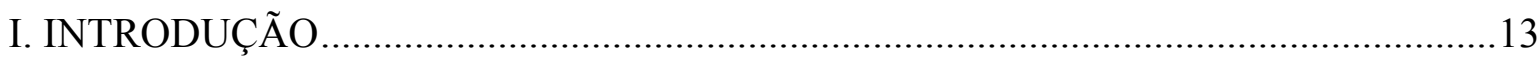

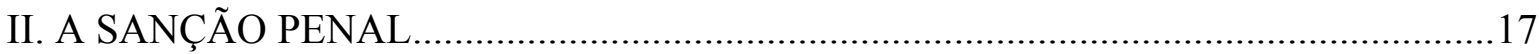

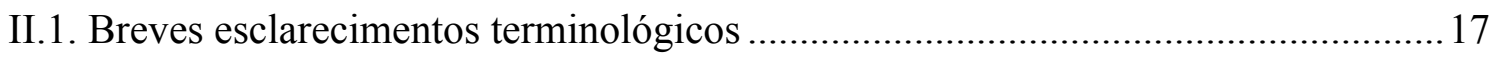

II.2. O castigo como resposta ao infrator ............................................................. 18

II.3. O poder punitivo do Estado e sua legitimidade de impor sanções........................... 19

II.4. A sanção penal e suas justificativas ................................................................. 21

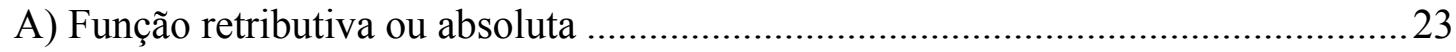

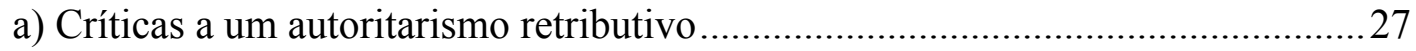

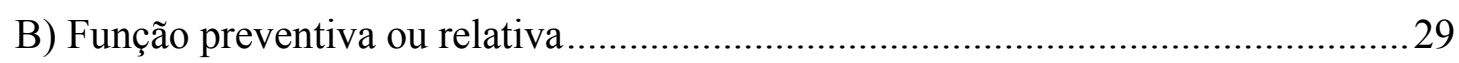

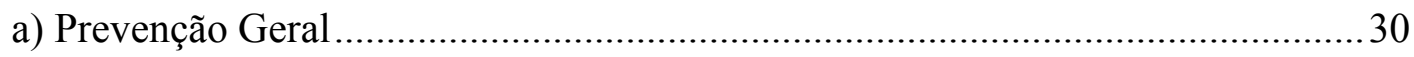

1. Prevenção geral negativa ou de intimidação.................................................... 31

2. Prevenção geral positiva ou de integração..................................................... 32

3. Críticas à instrumentalização do homem ........................................................ 34

4. Crítica à tutela da confiança geral na validade e vigência das normas do

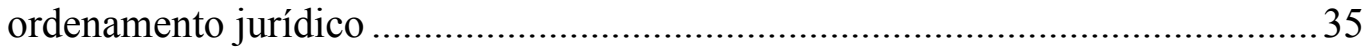

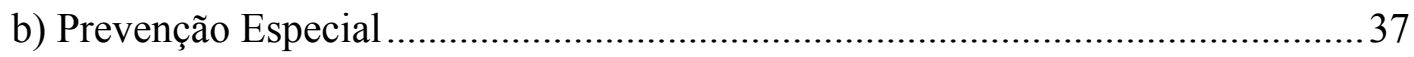

1. Crítica à sanção penal de duração indeterminada ...........................................39

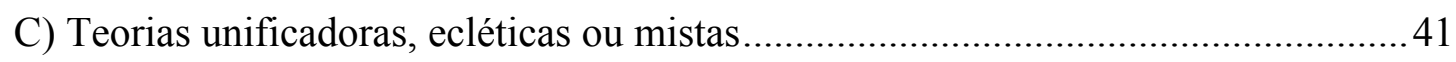

II.5. Notas sobre as finalidades das penas no Direito Penal moderno .............................42

III. OS FINS DAS PENAS E AS CARACTERÍSTICAS DOS DELITOS CONTRA O

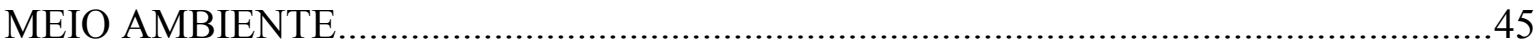

III.1. O bem jurídico ambiental e a prevenção geral integrativa limitadora ....................47

III.2. Os destinatários das normas penais ambientais e a prevenção especial positiva....52

III.3. A acessoriedade na legislação penal ambiental e a prevenção geral integrativa

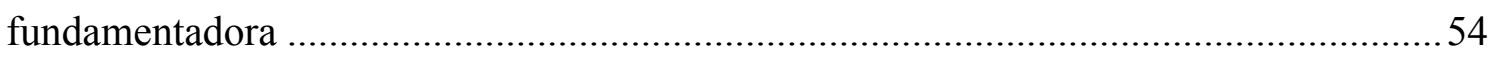

III.4. Delitos de perigo abstrato e a função retributiva ..................................................58

III.5. A reparação do dano, prevenção geral negativa e prevenção especial negativa.....62 
IV.1. O Direito Penal simbólico: em busca de um conceito

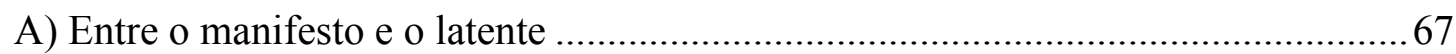

B) Entre os efeitos instrumentais e os expressivo-integradores ...............................69

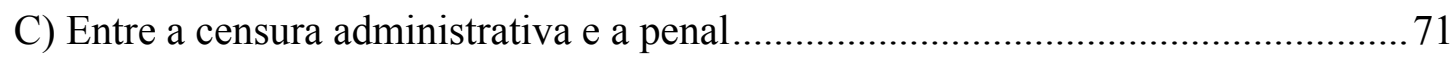

D) Entre a função ético-social, a função simbólica e a função de satisfação de

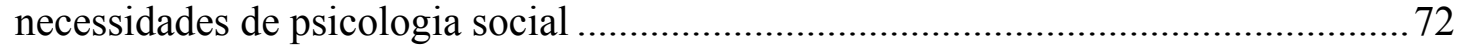

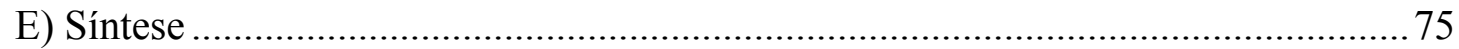

IV.2. O efeito simbólico no âmbito jurídico-penal do meio ambiente ........................... 79

IV.3. A tutela penal do bem ambiental e o princípio da intervenção mínima .................. 82

V. SANÇÕES APLICÁVEIS AOS CRIMES AMBIENTAIS .......................................99

V.1. Sanções penais aplicáveis às pessoas físicas ..........................................................99

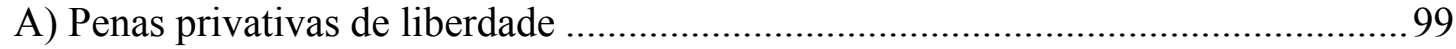

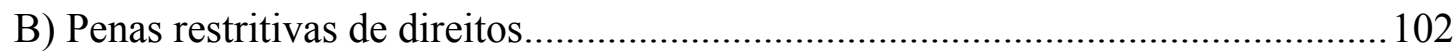

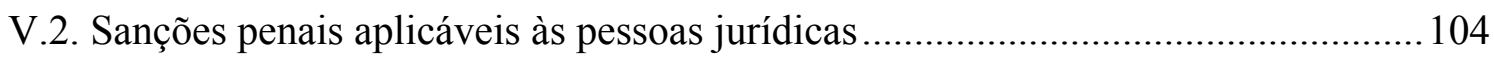

V.3. Semelhanças com as sanções administrativas e civis. ........................................ 110

V.4. O enfraquecimento do Direito Penal ambiental e os instrumentos processuais da Lei n. $9.099 / 95$.

\section{A LEI DE CRIMES AMBIENTAIS E SEUS IMPACTOS NOS TRIBUNAIS} BRASILEIROS

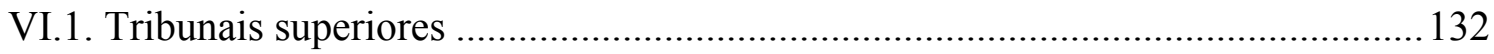

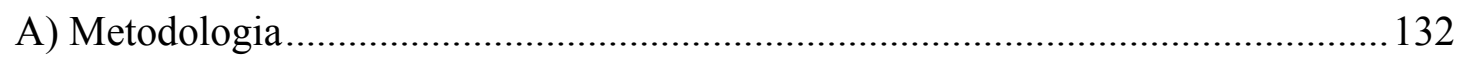

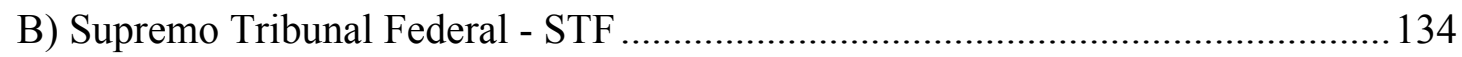

C) Superior Tribunal de Justiça - STJ .................................................................... 145

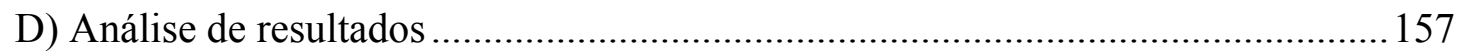

VII. Conclusões

Referências 


\section{INTRODUÇÃO}

O debate sobre as finalidades das penas nunca perdeu relevância nas reflexões metajurídicas, filosóficas ou ético-políticas sobre o Direito Penal. ${ }^{1} \mathrm{O}$ Estado, desde que adquiriu o monopólio da punição, sempre buscou justificações para garantir a legitimidade de aplicação da pena estatal, prévia e legalmente determinada.

Por ser considerada a intervenção mais gravosa sobre o cidadão, a sanção penal não se resume à simples concepção retribucionista de imposição de um mal em resposta a outro mal causado pelo infrator, mas se justifica como meio necessário de pacificação social, para assegurar bens jurídicos tutelados, impondo uma resposta corretora à infração de uma norma imprescindível para a vida em sociedade (HASSEMER, 1999, p. 324), reafirmando valores cuja vigência se pretende garantir (REALE JÚNIOR, 2009, p. 54).

Com o fim de cumprir essa função, as finalidades das penas se deparam com diferentes cenários em diversos modelos de Estado e, como o Direito Penal, espelham as modificações sociais. ${ }^{2}$

MIR PUIG (1995), demonstrando a correspondência entre Estado e pena, sustenta que a sanção, no Estado de base teocrática, teria um caráter assemelhado ao castigo divino para a busca da justiça. Por outro lado, em tempos do Estado absoluto, pode-se descrever um "terror penal", porque a pena era utilizada de modo arbitrário, sob a função de prevenção geral sem limites, como um instrumento totalitário de submissão dos súditos.

Com as mudanças do Estado liberal clássico para um Estado de Direito, a subordinação do poder punitivo ao Direito impôs-se como pauta de extrema importância. A perspectiva do Estado de Direito converteu a sanção penal, de castigo ilimitado, a

\footnotetext{
${ }^{1}$ Ao apresentar as questões do se, como, quando e por que punir, FERRAJOLI expõe que "as várias culturas jurídico-filosóficas tiveram sempre uma direta incidência prática na configuração das formas e das estruturas das instituições punitivas e de reflexo na ciência jurídico-penalista [...] Vale, igualmente, para outras tradições - éticas, positivas, idealistas e espiritualistas - que exercitaram influências não menos profundas e duradouras, seja na ciência seja na legislação e na prática penal" (2006, p. 197). Conclui, portanto, o autor que a evolução e a reflexão do Direito Penal basearam-se nas doutrinas ético-políticas, filosoficamente caracterizadas ao redor do objetivo da pena, servindo como teorias justificadoras metajurídicas, filosóficas ou ético-políticas.

${ }^{2}$ SANTIAGO MIR PUIG sustenta que "las funciones propias del Estado Social y Democrático de Derecho han de condicionar la función a asignar al Derecho penal. La pena es un instrumento que puede utilizarse con fines muy diversos. En el Estado moderno se considera monopolio del Estado, por lo que su función dependerá de los cometidos que se atribuyan al Estado." (MIR PUIG, 1995, p. 28-29).
} 
resposta juridicamente delimitada, sujeita a balizas decorrentes de valores como a igualdade absoluta do homem ideal frente à lei. No Estado liberal clássico, a aplicação da justiça estava relacionada com a retribuição, na medida em que se aplicavam penas preestabelecidas juridicamente conforme seu merecimento, mas sem a flexibilidade de não aplicação aos casos em que a sanção penal não era necessária (rigidez legal).

Somente com o surgimento do Estado Social, o poder punitivo assumiu a intrincada tarefa de modular a sanção penal, aplicando tratamentos diferenciados a pessoas que cometeram o mesmo delito. A antiga igualdade formal do liberalismo foi substituída, em um Estado intervencionista que valoriza a prevenção especial, foi substituída por um Direito Penal concebido como instrumento para a luta contra a delinquência. Sanções como a medida de segurança, a considerar as particularidades do sujeito infrator, passaram a ser impostas de maneira individualizada. Se, por um lado, a individualização da pena poderia aproximar o sistema punitivo dos ideais de igualdade material, ao sintonizar as penas conforme os diferentes autores de delitos, por outro poderia levar a sistemas políticos totalitários, que impusessem tratamentos distintos a determinados indivíduos, transformados em alvos por uma concepção de Direito Penal do autor-inimigo.

Considera-se central no debate acerca das finalidades das penas a ideia de que as clássicas teorias retributivas e preventivas, analisadas em nosso contexto sociocultural, necessariamente se modificam na sociedade moderna globalizada, razão pela qual no Estado democrático de Direito, as constantes mutações na legislação penal repercutem no sentido da pena de forma inédita. ${ }^{3}$

A utilização da intervenção jurídico-penal para a extensa gama de esferas com as quais o Estado moderno se ocupa, como por exemplo os direitos difusos, ${ }^{4}$ aproxima o Direito Penal do Direito Administrativo. Como afirma HASSEMER:

\footnotetext{
${ }^{3}$ WINFRIED HASSEMER ao perguntar se a ampliação do Direito Penal teve alguma repercussão sobre a questão do sentido da pena, responde: "Estoy absolutamente convencido de que la respuesta es afirmativa. Un Derecho penal que se circunscribe a los bienes jurídicos de la persona y sólo atiende a los bienes jurídicos de carácter colectivo cuando éstos se pueden aprehender con precisión y guardan una relación con intereses de carácter personal (como por ejemplo, la puesta en peligro del tráfico vial, la búsqueda de la verdad formal en un proceso, o la posesión de objetos peligrosos), representa una concepción de pena distinta a la de un Derecho penal que protege la capacidad funcional de las subvenciones o del tráfico de divisas o que incluso permite la imputación colectiva de hechos a personas jurídicas, por ejemplo a una junta directiva, como probablemente vamos a ver en un futuro." (HASSEMER, 1999, p. 329).

${ }^{4}$ Neste trabalho, apesar das críticas terminológicas de SUSANA SOTO NAVARRO, adota-se a denominação de bens jurídicos "difusos", esclarecendo que se trata dos "interesses difundidos", presentes de modo informal e propagados de forma massificada em certos setores da sociedade, equiparando aos "bens supra-individuais" e tratando de forma indistinta os termos genéricos "coletivos" ou "universais". Ver SOTO NAVARRO (2003, p. 193-194) e MATA BARRANCO (1996, p. 42). SILVEIRA (2003) esclarece que os bens jurídicos difusos são os que
} 
Isto repercute também na concepção de pena defendida. Já não se trata de restabelecimento de bens jurídicos palpáveis (e da confirmação de normas lesionadas por meio deste restabelecimento, vide supra, VIII); trata-se de adivinhação de riscos, de domínio de perigo, de intervenção, inclusive, antes que se produza a lesão. A diferença entre repressão e prevenção, que tradicionalmente separa o Direito Penal do Direito Administrativo ou de Polícia, converte-se em incômoda e obsoleta. Agora o que queremos é prevenção a todo custo, sem exceção e com as armas mais sofisticadas. (HASSEMER, 1999, p. 329). ${ }^{5}$

Diante do atual Direito Penal expansionista, a proteção dos bens jurídicos difusos possui especial relevância para a análise das finalidades das penas. ${ }^{6}$ As características desta regulação no ordenamento - a acessoriedade administrativa, os crimes de perigo abstrato, a pluralidade de atos, a influência das pessoas jurídicas e a questão da reparação de dano junto ao Estado $^{7}$ - apontam a uma reflexão sobre as justificativas para a imposição da sanção penal referente aos bens jurídicos difusos.

Este trabalho tem como objeto a análise das funções a serem desempenhadas pelas penas impostas aos delitos contra os direitos difusos, mais precisamente nos casos dos crimes contra o meio ambiente. Busca-se indicar, pois, as justificativas da atuação do Estado no ato de punir os infratores ambientais, sob as teorias da retribuição, prevenção geral e especial, bem como o simbolismo da pena e suas particularidades no âmbito do Direito Penal dos interesses difusos. Nesse contexto, questiona-se se a função simbólica de pena assume um papel destacado, como elemento diferenciador de uma moderna teoria da pena.

Qualquer que seja a proteção legislativa aos bens jurídicos supra-individuais, é impossível ignorar os problemas específicos que resultam da aplicação da sanção penal no âmbito dos crimes econômicos coletivos, que permeiam debates sobre o conceito material de delito e culpabilidade, a criação do risco, a natureza difusa dos interesses protegidos, a relevância da tutela penal dos bens jurídicos difusos, as características criminológicas do infrator nos crimes econômicos, a responsabilidade penal das pessoas jurídicas, o direito administrativo sancionador, bem como a ideia de Direto Penal mínimo baseado no

dizem respeito a valores genéricos, valores estes referentes a interesses de pessoas que têm entre si vínculos também genéricos, próprios de um contexto com características acidentais e mutáveis.

${ }^{5}$ Tradução livre da autora. Todas as traduções subsequentes do espanhol neste trabalho são traduções livres da autora.

${ }^{6}$ Nesse contexto, SILVA SÁNCHEZ apresenta o panorama do Direito Penal de duas velocidades, em que a modernização do Direito Penal caracteriza-se pela expansão e flexibilização de princípios político-criminais e, consequentemente, alteração as regras de imputação do Direito Penal da pena privativa de liberdade (2008b, p. 176-182).

${ }^{7}$ Cf. MACHADO (2005). 
princípio da lesividade. Tais tópicos constituirão o pano de fundo da discussão central da pesquisa proposta, não sendo, portanto, objeto de estudo aprofundado neste momento.

Esta pesquisa cinde-se em três linhas temáticas: 1. o poder e dever do Estado de impor sanções penais e as justificativas tradicionais da pena; 2. as características do Direito Penal ambiental em relação às finalidades das penas; 3. a função simbólica da pena.

O capítulo 2 busca expor o poder estatal de impor penas e os discursos oficiais para a justificativa dessas medidas de coerção. O capítulo 3 descreve o panorama específico do Direito Penal ambiental, incluindo suas nuances dogmáticas, para verificar a aplicabilidade das teorias das penas nesse campo. No capítulo 4, pergunta-se qual o conteúdo do caráter simbólico da pena e quais seriam os possíveis discursos extraoficiais sobre a justificativa penal. Para ilustrar o conteúdo abordado, trabalha-se no capítulo 5 as penas aplicáveis aos crimes contra o meio ambiente. Por fim, verifica-se, no capítulo 6, o impacto dos crimes ambientais nos tribunais superiores brasileiros.

Em síntese, no contexto da proteção penal do meio ambiente, a presente pesquisa tem como fito averiguar a efetividade da intervenção estatal ao impor pena aos infratores da legislação penal ambiental. A verificação dos fins das sanções do Direito Penal focalizará sua (in)compatibilidade com as justificativas de um sistema penal no Estado democrático de Direito. 


\section{A SANÇÃO PENAL}

\section{II.1. Breves esclarecimentos terminológicos}

A resposta verificável ao não-cumprimento de uma regra de conduta penal pode ser descrita por diversos termos. Ainda que possam parecer quase idênticos e se confundam terminologicamente, neste trabalho, sob a lição de FALCÓN y TELLA (2005, p. 16), faz-se a clivagem destes conceitos, que não serão tomados como sinônimos perfeitos.

Para o castigo, dá-se um significado amplo, representando não apenas a resposta jurídica a uma conduta contrária ao ordenamento, mas também a toda e qualquer forma de reação, inclusive o repúdio social ou psicológico.

A sanção abrange o castigo oriundo de regras jurídicas, para o qual o Direito apresenta as linhas de imposição, com a característica fundamental de coercibilidade e diminuição de direitos aos que infringem as condutas previstas normativamente.

A sanção penal, por sua vez, equivale à sanção jurídica própria do Direito Penal. Embora FALCÓN y TELLA (2005, p. 16) tenham relacionado a sanção penal com o conceito de sanção, parece acertado discernir estes conceitos, cingindo a sanção penal à resposta jurídica ao comportamento ilícito penal.

A sanção penal é o conjunto de castigos verificáveis no âmbito do Direito Penal, cujas espécies principais são a pena e a medida de segurança. Ainda existe discussão sobre a natureza jurídica das medidas aplicáveis às pessoas jurídicas ${ }^{8}$ (SILVA SÁNCHEZ e ORTIZ DE URBINA GIMENO, 2006) correspondentes aos crimes ambientais (embora chamadas de penas na Lei n. 9.605/98).

As medidas de segurança não serão tratadas neste trabalho, diante de suas peculiaridades, ${ }^{9}$ as quais merecem uma pesquisa própria. O objeto central do trabalho será a análise das penas no Direito Penal do Meio Ambiente, que trazem consigo um extenso

\footnotetext{
${ }^{8}$ Cf. na doutrina brasileira, SHECAIRA (2003).

${ }^{9}$ A medida de segurança trabalha com uma lógica própria. Seu objetivo consiste em apresentar uma resposta jurídica àqueles que praticaram uma conduta delituosa destituídos de liberdade e imputabilidade. Diversamente da pena, que pressupõe indivíduos livres culpáveis e imputáveis, as medidas de segurança são impostas nas situações em que o agente não tem capacidade de discernimento e consciência da antijuridicidade. Por esse motivo, possuem as medidas de segurança natureza e fundamentos particulares, baseada na periculosidade do sujeito. Sobre o tema: FERRARI (2001); REALE JÚNIOR ET ALLI (1985).
} 
acervo de discussões acerca de sua finalidade e legitimação, principalmente em relação aos novos crimes. ${ }^{10}$

Por último, anota-se a utilização do termo punição, que, segundo FALCÓN y TELLA (2005, p. 17), expressa a sanção de outras disciplinas distintas das sanções penais - o que se denomina penalty em inglês e pénalité em francês. Todavia, em geral, o vocábulo é empregado como representação de um mal imposto a uma conduta reprovável, aproximando-se da ideia de castigo, a englobar desde a autopunição, passando pela repressão divina e inclusive a sanção jurídica. Neste trabalho, dar-se-á preferência ao termo castigo.

\section{II.2. O castigo como resposta ao infrator}

O castigo existe desde as sociedades primitivas, em distintas representações, sejam morais, sejam divinas. Para KELSEN (2001, p. 225), a convivência dos indivíduos gera imediatamente uma ordem social, composta por um conjunto de normas, capazes de determinar como o sujeito deve se conduzir em relação aos outros. A conduta socialmente desejada pode ocorrer por uma motivação direta, ou seja, por obediência voluntária, em razão da atração dos indivíduos à conduta, pelo simples fato de que esta esteja prevista na norma. Ou ainda pode a conduta ser observada por uma motivação indireta de medida de coerção, traduzida por normas que respondem de forma determinada (recompensa ou punição) à conduta, ${ }^{11}$ dirigindo o comportamento dos sujeitos.

Nenhuma norma, segundo KELSEN, gera suficiente atração nos indivíduos para desencadear a obediência voluntária; a conduta social, entretanto, produz, ao menos, um juízo de valor que implica uma "sanção de ordem" (KELSEN, 2001, p. 226), como reação do grupo à aprovação ou reprovação à conduta, simbolizando uma coerção no sentido psicológico.

\footnotetext{
${ }^{10}$ Neste caso, faz-se referência aos crimes previstos na Lei de Crimes Ambientais, criados no final da década de 1990, e a suas recentes modificações trazidas pelas Lei n. 11.428, de 22 de dezembro de 2006; Lei $n$. 11.284, de 02 de março de 2006; e pela Lei n. 12.305, de 02 de agosto de 2010.

${ }^{11}$ HANS KELSEN (2001, p. 225) utiliza, para a explicação dessa motivação indireta, o princípio da retribuição, no qual a conduta em conformidade com o ordenamento é associada com uma promessa de vantagem; e a conduta contrária à ordem com uma ameaça de desvantagem. Para não existir uma confusão terminológica com a teoria da retribuição da pena, não se utilizou esta expressão para descrever o pensamento kelseniano.
} 
Partindo dessa premissa, o autor realiza a distinção entre os castigos de caráter transcendental (religioso) e aqueles de natureza social-imanente (ou social-organizado), afirmando que os primeiros são aplicados por uma autoridade sobre-humana, uma divindade, que "lança" um castigo (como a má sorte na caça, doenças, morte etc.). Os castigos socialmente imanentes, em contraste, devem ser cumpridos pelos indivíduos conforme dispositivos de ordem social. A vingança de sangue constitui o mais primitivo dos castigos, que se relaciona a uma infração ocorrida. Sob a "técnica da recompensa", o autor repudia a conduta indesejada pela ameaça de aplicação de um mal à conduta contrária à ordem. Trata-se de uma ordem coercitiva, cuja eficácia repousa nas medidas de coerção $^{12}$ e no medo do castigo (KELSEN, 2001, p. 227).

\section{II.3. O poder punitivo do Estado e sua legitimidade de impor sanções}

Como consequência da organização social dos castigos socialmente imanentes, o Direito configura para KELSEN uma "técnica social específica de uma ordem coercitiva" (KELSEN, 2001, p. 230), que orienta a conduta desejada aos indivíduos por meio de uma ameaça de coerção às condutas contrárias. As características distintas da sanção com relação às respostas primitivas consistem na previsão e caráter do castigo e no aplicador.

Em oposição ao castigo moral - que provém de uma reprovação aplicada por indivíduos semelhantes, não prevista em uma ordem moral e não socialmente organizada e ao castigo divino - que deriva de uma autoridade sobre-humana, com previsão de ordem religiosa, mas não socialmente organizada - a medida de coerção do Direito, a sanção jurídica, está previamente descrita no ordenamento. A sanção jurídica, portanto, é socialmente organizada e aplicada por outro homem, representante da comunidade social, designado pelo ordenamento e por ele autorizado a impor um mal (KELSEN, 2001, p. 231233).

No âmbito jurídico, o uso da força está proibido nas relações diretas entre os indivíduos. O Direito organiza a utilização da força, criando um monopólio, em que somente o indivíduo, autorizado pelo ordenamento, pode aplicar uma medida coercitiva, atuando como um órgão da comunidade constituída pela ordem, para reagir à proibida

\footnotetext{
12 As medidas de coerção são apresentadas por $\operatorname{KELSEN~(2001,~p.~228)~como~um~mal~representado~pela~}$ privação de posses contra a vontade do possuidor.
} 
intervenção de um indivíduo na esfera dos interesses alheios, quando a conduta de se abster havia sido induzida pelo Direito (KELSEN, 2001, p. 225-250).

Já não é o prejudicado (vítima), pois, quem tem o direito de punir, de maneira descentralizada. O Estado, detentor do monopólio da violência, centraliza esta função; por meio da renúncia dos indivíduos ao direito de autodefesa, o Estado passa a aplicar medidas de coerção em nome próprio (pretensão punitiva estatal ou pública) (GÜNTHER, 2006, p. 191).

Esse panorama repudia um sistema abolicionista, já que uma sociedade que renuncia ao poder punitivo estaria igualmente renunciando a sua existência, porque o castigo (moral, religioso ou jurídico) é entendido como um mal necessário para a convivência dos homens.

Sobre o poder de impor um mal aos demais (castigo), FALCÓN y TELLA (2005, p. 2425) polemizam ao indagar como uma autoridade determinada pelo sistema jurídico pode ser legitimada a atuar, em nome do Estado, para infligir um mal (sanção). Assim, expõem:

Se um delito é cometido. Por meio dessa ação se produz um mal em um triplo sentido: para a vítima - a dor física -, para a sociedade - a violação da ordem - e, inclusive, para a alma do ofensor - um mal moral. Mas a situação é melhorada pela adição de um quarto mal - um dano ou dor ao ofensor - que, em princípio, não reporta nenhum bem, nem a ele nem à sociedade, tampouco ao ofendido, pois o mal só se soluciona com um bem em sentido contrário, não com outro mal? (FALCÓN y TELLA, 2005, p. 24-25).

Como resposta a essas indagações, os autores afirmam que "o mal intrínseco ao castigo é um mal ao cinquenta por cento" (FALCÓN y TELLA, 2005, p. 24), porque não é um mal absoluto, tampouco um bem pleno. Ainda que nunca possa ser integralmente um bem e que seja eticamente reprovável, este mal está escusado juridicamente e não se apresenta como um ato censurável. Ao contrário, apresenta-se como um ato necessário, por ser um "mal a serviço do bem".

Este mal, chamado sanção penal, somente admite sua aflição pelo Estado se cumprir certas exigências ou requisitos para legitimá-lo: “deve existir uma ofensa prévia portanto, basear-se em uma pretensão justa -; deve ser um meio indispensável; deve ser proporcional, imposto por uma autoridade legítima sem ânimo de vingança e para alcançar algum fim. Não deve ser um fim em si mesmo. Ainda que não logre o pretendido por postulados teológicos, ou seja, a aflição ou emenda moral do delinquente, ao menos deve 
buscar-se sua reeducação ou reinserção social, que seu comportamento externo não cause dano à ordem social" (FALCÓN y TELLA, 2005, p.25).

Dentre os meios de controle social existentes, o Direito Penal apresenta-se como o cume de todas as instâncias de controle. Por ser dotado de sanções de especial gravidade aos direitos fundamentais, o poder punitivo estatal exige princípios limitadores do ius puniendi para intervir de forma mínima, fazendo-o em atenção aos princípios de ultima ratio, de subsidiariedade, de fragmentariedade, de exclusiva proteção dos bens jurídicos, de legalidade, de culpabilidade ${ }^{13}$ e de proporcionalidade (MIR PUIG, 2007, p. 111-138). Assim, esse ramo do Direito deveria ser acionado, segundo a doutrina, ${ }^{14}$ unicamente quando outras formas de controle social se mostram insuficientes.

Compete ao Estado delimitar qual será a forma e oportunidade de aplicação das sanções penais como resposta justa e útil de controle e combate ao fenômeno denominado "crime", além de determinar quais serão as justificativas jurídicas ${ }^{15}$ que indicam os fins que as penas devem cumprir:

A utilização de reações penais por parte da intervenção penal precisa ser fundamentada. Isto constitui um nível argumentativo prévio no que concerne à legitimação dos diversos efeitos sociais que se quer causar com elas, eis que resultará impossível legitimar a busca de qualquer finalidade social por meio do mecanismo da pena, se o uso dela não for fundamentado. (DÍEZ RIPOLLÉS, 2003, p. 152-153).

\section{II.4. A sanção penal e suas justificativas}

A teoria das finalidades das penas gravita em torno de duas principais teorias: teoria absoluta ou retributiva e teoria relativa ou preventiva (geral ou especial). O âmbito de estudo afigura-se vasto por força das diversas variações existentes no seio destas teorias,

\footnotetext{
${ }^{13}$ Em trabalho minucioso, ROXIN (1981) apresenta a relação entre a culpabilidade e a prevenção no Direito Penal.

${ }^{14}$ SILVA SÁNCHEZ, em exposição sobre a eficiência e o Direito Penal, indica que, na perspectiva preventivo geral, somente existe justificativa para as penas cominadas e impostas pelo Estado se satisfeitas ao menos quatro condições: "a. estas penas dissuadissem outras pessoas que cometerem infrações ao Direito; b. evitarem mais sofrimento do que o próprio delito ocasionaria; c. não houver outra forma de pena que, com a mesma eficácia preventiva, produza um dano menor; e, d. a pena não for substituível por outra medida com o mesmo efeito preventivo e que cause menor sofrimento" (SILVA SÁNCHEZ, 2004, p. 32-33).

${ }^{15}$ Sobre a importância de justificativa das sanções impostas pelo Estado, ROJAS anota que: "La pena es la manifestación del poder estatal de juzgar conductas y castigarlas. Sea como modo de pacificar, de imponer ciertos valores o de proteger los derechos, la pena ha sido considerada las herramientas del Estado para lograr sus objetivos. Por eso es tan importante examinar cuál es el fin que persigue esa coerción unilateral del Estado sobre un individuo" (ROJAS, 2000, p. 95).
} 
visto que sobre elas se debruçou uma parte considerável da história da filosofia do Direito e da teoria do Direito Penal, esforçando-se na busca das finalidades das sanções penais (FERRAJOLI, 2006, p.235). Dada a diversidade de análises possíveis, não se tem a pretensão de recorrer a todos os pensamentos existentes sobre o tema; intenta-se, não obstante, reagrupar as principais ideias em torno das teorias das finalidades das penas.

Apesar de as teorias absoluta e relativa consistirem, aparentemente, em concepções que se contrapõem, o que será objeto de análise mais adiante, é pouco disseminada a defesa de tais teorias "puras", isoladas; ganham importância, em oposição, as variações unificadoras, ecléticas ou mistas. ${ }^{16}$

A separação radical de teorias absolutas e relativas consubstancia mera simplificação esquemática para sua exposição. Como explica SILVA SÁNCHEZ, na prática elas não se mostram unilaterais; ao contrário, "concretamente, destaca-se que todos os clássicos caracterizados como 'retribucionistas' atribuíam também ao Direito Penal a missão de conseguir fins preventivos, enquanto os catalogados como 'preventivistas' também se mostravam próximos aos retribucionistas" (SILVA SÁNCHEZ, 2002, p. 198).

Antes de tratar dos conteúdos básicos de cada uma de tais propostas, convém assinalar que persistem recorrentes controvérsias sobre o conteúdo, a interação e a própria existência das finalidades das penas, como forma de justificar a intervenção punitiva do Estado. Neste contexto, indicamos a posição dos defensores das teorias "negativas" ou abolicionistas, para os quais não existe razão e justificativa para a manutenção do Direito Penal e, igualmente, para o emprego da pena como instrumento de sua concretização. Os abolicionistas defendem a eliminação do Direito Penal, seja porque contestam seu fundamento ético-político, seja porque as suas vantagens são entendidas como inferiores aos custos sociais (FERRAJOLI, 2006, p. 231-235). Adotada a posição abolicionista, nenhum outro debate sobre a finalidade das penas é necessário, porque, desde a raiz, não se reconhece justificação alguma ao Direito Penal. Esta não é a postura adotada no presente trabalho; por essa razão, seguimos com a apuração das finalidades retributivas e preventivas.

\footnotetext{
${ }^{16}$ MARÍA JOSÉ FALCÓN Y TELLA e FERNANDO FALCÓN Y TELLA tratam deste tema: “¿Son irreconciliables ambas teorías - el retribucionismo y el utilitarismo o teoría de la prevención-? Lo serían en sus versiones extremas, por ejemplo si el utilitarismo llegase a justificar con fines de prevención general el castigo de inocentes. Pero, sin embargo, en su sentido moderno, más moderado, dichas concepciones serían conciliables. Así se evitaría anclarse en el retribucionismo clásico, hoy superado, que si funcionase de manera aislada, como función exclusiva de la sanción penal, se convertiría en una tesis primitiva y cruel, alejada del racionalismo y de los valores humanitarios que nuestra cultura occidental defiende desde los tiempos de la Ilustración" (FALCÓN Y TELLA, 2005, p. 152).
} 


\section{A) Função ${ }^{17}$ retributiva ou absoluta}

O próprio nome da teoria já destaca suas características. A teoria absoluta da pena obriga, como exigência de justiça e de forma categórica, a imposição de um castigo direcionado à pessoa que causou o dano pelo fato delituoso cometido de forma culpável.

Além da exigência integral de justiça, o caráter "absoluto" da pena manifesta-se como uma resposta punitiva que se impõe incondicionalmente, como um valor em si mesmo, independente de sua utilidade à sociedade. ${ }^{18}$ Assim, sempre que houver delito, em todas as ocasiões em que ele se verificar, inexoravelmente, deve existir a sanção. Não se requer outra justificativa ou finalidades transcendentes ao mero castigo, por seu valor axiológico intrínseco.

Sempre com visão retrospectiva, a teoria determina que somente existe pena depois do fato culpavelmente cometido (punitur quia peccatum est). Dessa forma, restabelecem-se os valores da sociedade, pela compensação da culpa por algo já ocorrido.

Do termo "retributivo", por sua vez, extrai-se outra característica clássica, consistente na busca da reparação de um dano causado à vítima pelo responsável da conduta danosa. Sob o fundamento de compensação, incide ao autor do dano o mesmo que incidiu à vítima ("olho por olho, dente por dente").

MIR PUIG, ao situar a tese da retribuição na "arraigada convicção de que o mal não deve ficar sem castigo e o culpável deve encontrar nele o seu merecido" (2007, p. 87-90), fraciona os fundamentos da teoria em razões religiosas, éticas e jurídicas.

A influência dos pensamentos religiosos na teoria retributiva é evidente nas passagens dos textos bíblicos, como na lei de talião do direito hebreu. No livro Êxodo, capítulo 21, versículo 22-25 e no Levítico, capítulo 21, versículo 19-21, lê-se:

Se alguns homens pelejarem, e um ferir uma mulher grávida, e for causa de que aborte, porém não havendo outro dano, certamente será multado, conforme o que lhe impuser o marido da mulher, e julgarem os juízes. Mas se houver morte, então darás vida por vida, Olho por olho, dente por

\footnotetext{
${ }^{17}$ Diferentemente de FERRAJOLI (2006, p. 200), utiliza-se neste trabalho o termo "função" para indicar as finalidades que a pena deve perseguir a fim de tornar justificável o Direito Penal.

${ }^{18}$ HASSEMER e MUÑOZ CONDE (1989, p. 151) indicam a desvinculação da pena na teoria absoluta de fins utilitários e efeitos sociais: "Los textos de Kant y Hegel, que hemos citado antes, deben entenderse como productos de la polémica que dichos filósofos mantenían contra la concepción relativista de la pena que dominaba en su época, a la que precisamente reprochaba Hegel que trataba al condenado como a un perro con un palo, en lugar de respetar su honor y su libertad. Y también Kant criticaba que el condenado pudiera "ser utilizado como un simple medio de las intenciones de otros y mezclando con los objetos del Derecho patrimonial' tanto si la pena se imponía en su beneficio, como en el de otro.”
} 
dente, mão por mão, pé por pé, Queimadura por queimadura, ferida por ferida, golpe por golpe.

Quando alguém ferir o seu próximo, terá de ser ferido da mesma forma que o fez: fratura por fratura, olho por olho, dente por dente. O que alguém fizer a outro assim lhe será feito. Repetindo: quem matar um animal deverá restituí-lo por outro, e quem matar um ser humano, morrerá.

Essa vinculação da função absoluta retributiva com a religião é própria das civilizações primitivas (KELSEN, 2001, p. 225-250) e do Estado de base teocrática, cujo poder é centralizado em uma pessoa eleita por Deus ${ }^{19}$ (MIR PUIG, 1995, p. 28).

Nas idades moderna e contemporânea, a teoria absoluta se assenta na filosofia idealista alemã. ${ }^{20}$ Para ilustrar os fundamentos da teoria pela perspectiva ética, IMMANUEL KANT é o tradicional expoente mencionado. Partindo de uma concepção de liberdade de vontade, sua teoria da retribuição moral ou ética, expressada na Metafísica dos Costumes, considera que o homem, por seu livre arbítrio, pode decidir pelo mau uso da sua liberdade, com a comissão do delito. ${ }^{21} \mathrm{~A}$ realização de um mal culpável reivindica o imperativo categórico $^{22}$ do castigo ao infrator, como imposição incondicionada da justiça.

A pena constitui uma retribuição ética que se justifica por meio do valor moral da lei penal violada e do castigo que a ele é imposto, devendo ser aplicada unicamente porque houve a infração à lei.

\footnotetext{
${ }^{19}$ Como exemplo da lógica retributiva, lê-se no Código de Hammurabi: 196. Se um homem arrancar o olho de outro homem, o olho do primeiro deverá ser arrancado [Olho por olho]. 197. Se um homem quebrar o osso de outro homem, o primeiro terá também seu osso quebrado. 200. Se um homem quebrar o dente de um seu igual, o dente deste homem também deverá ser quebrado [Dente por dente].

${ }^{20}$ Entre os partidários da teoria absoluta, FERRAJOLI nomeia "não apenas HEGEL e KANT, mas, e antes mesmo, por CAMPANELLA, SELDEN, LEIBNIZ e GENOVESI, bem como, e posteriormente, de maneira ainda mais tenaz, por uma grande série de filósofos, e, principalmente, de juristas. Basta recordarmos, entre os maiores expoentes, PELLEGRINO ROSSI, ANTONIO ROSMINI, TERENZIO MAMIANI, ENRICO PESSINA, TANCREDI CANONICO, GIUSEPPE MAGGIORE, GIUSEPPE BETTIOL e VITTORIO MATHIEU, na Itália, LUDWING HEINRICH JAKOB, JULIUS FRIEDRICH ABEGG, ALBERT FRIEDRICH BERNER e KARL BINDING na Alemanha, o juiz vitoriano JAMES FITZJAMES STEPHEN na Inglaterra, e, mas recentemente, a orientação anticorrecional desenvolvida nestes últimos anos nos Estados Unidos sob o título de Justice Model, que agrega as orientações liberais de MORRIS, HAWKINS e FOGEL àquelas moralistas de SINGER e DERSHOWITZ baseadas na idéia de 'pena merecida', bem como, e por derradeiro, aquelas alarmistas de VAN HAAG e de VON HIRSCH." (FERRAJOLI, 2006, p. 238, grifos do autor).

${ }^{21}$ A respeito, ROJAS expõe que "Kant, quién justifico la imposición de la pena en el libre albedrío, desconociendo cualquier fundamento en razones de utilidad social. Para Kant, el autor de un delito debía responder porque tenía la libertad de comportarse de otro modo, y sin embargo eligió delinquir, teniendo por lo tanto la pena la calidad de una retribución ética, justificada por el valor moral de la ley penal infringida por el culpable y del castigo que consiguientemente se inflige" (ROJAS, 2000, p. 98).

${ }^{22}$ Nas palavras de KANT: "La ley penal es un imperativo categórico y ¡ay de aquél que se arrastra por las sinuosidades de la doctrina de la felicidad para encontrar algo que le exonere del castigo, o incluso solamente de un grado del mismo, por la ventaja que promete siguiendo la divisa farisaica 'es mejor que un hombre muera a que perezca todo del pueblo'. Porque si perece la justicia, carece ya de valor que vivan hombres sobre la tierra" (KANT, 1989, p. 167).
} 
O indivíduo, ao atuar livremente e com capacidade de vontade, gerando um mal, torna-se moralmente reprovável, o que demanda a imposição da pena, que vem a compensar e expiar o mal causado pelo delito e restabelecer a ordem de valores.

A culpabilidade do sujeito estabelece-se como pressuposto da pena, bem como representa seu limite, uma vez que a dupla função da culpabilidade para a imposição da sanção penal exige, em primeiro plano, um mal causado pela livre determinação do sujeito, afastando os casos de incapacidade de vontade, e, em segundo plano, assinala uma sanção que não pode ultrapassar a medida do mal, razão por que "somente a lei do talião (ius talionis) pode oferecer com segurança a quantidade e qualidade do castigo" (KANT, 1989, p.167).

A explanação de KANT representa não apenas uma resistência às teorias preventivas, que utilizavam o homem como exemplo e o instrumentalizavam em benefício da sociedade, mas também - e principalmente - uma valorização da dignidade humana. Segundo KANT, o homem é um fim em si mesmo e não pode ser um fim para a pena. Portanto, a pena judicial "não pode nunca servir simplesmente como meio para fomentar outro bem, seja para o próprio condenado seja para a sociedade civil, mas deve ser imposta a ele somente porque delinquiu" (KANT, 1989, p.166).

Finalmente, os fundamentos da teoria da retribuição jurídica são relacionados com o filósofo FRIEDRICH HEGEL (1997). A teoria da retribuição hegeliana apresenta características semelhantes aos sistemas jurídicos da modernidade. Por um procedimento lógico-dialético, o delito é uma negação do ordenamento e a pena produz a negação desta negação, protagonizando a necessidade de restabelecer a vigência da "vontade geral" (MIR PUIG, 2007, p. 88), reafirmando a ordem jurídica. MIR PUIG, assim, expõe o método dialético hegeliano:

A vontade geral (ordem jurídica) é a 'tese', a negação da mesma pelo delito é a 'antítese', e a negação desta negação será a 'síntese', que terá lugar mediante o castigo do delito. Nesta construção, a pena se concebe apenas como reação (negação da negação) que olha o passado (ao delito e o restabelecimento da ordem jurídica) e não como instrumento de fins utilitários posteriores. (MIR PUIG, 2007, p. 88).

A função da pena, para $H E G E L$, está conectada com a expressão comunicativa, no sentido de transmitir a mensagem de afirmação do Direito frente à negação da norma (GÜNTHER, 2006, p. 219). Esta mensagem de eliminação do injusto caracteriza-se como "restabelecimento da relação de reconhecimento recíproco entre os cidadãos - infringida pelo delito" (SILVA SÁNCHEZ, 2008a, p. 1). A dupla negação da pena atua como uma 
retribuição jurídica, caracterizada por uma violência em sentido contrário, capaz de anular a violência do ato ilícito, com o fím de restabelecer o ordenamento legal violado. ${ }^{23}$

GÜNTHER afirma, fazendo referência a $J A K O B S$, que o nível de abstração se acentua, precisamente porque a pena, como um mal estipulado normativamente, desprende-se de signos fáticos, bastando-lhe a representação da mensagem estrita da prescrição normativa a resultante reafirmação do ordenamento é tautológica. A negação pública do delito (referido por GÜNTHER como contranorma) ocorre por meio da pena, que estabelece uma relação de comunicação entre condenado e sociedade, para reforçar a validade da norma contrariada e negar o delito (refutando a contranorma). Para o autor, com esse fim, "a pena fica reduzida a mero ato performático", tendo como objetivo reafirmar proposições previstas no ordenamento (GÜNTHER, 2006, p. 192).

Em suma, a teoria absoluta ou retributiva ${ }^{24}$ apóia-se na concepção da pena como “justiça da punição", devendo ser aplicada como resposta obrigatória, em justa medida, quando ocorre a prática de um delito, ainda que não se veja a utilidade desta resposta à sociedade, justificando-se pela necessidade de retribuir a perturbação causada, de maneira proporcional, e de restabelecer a vigência da "vontade geral" apresentada pela ordem jurídica.

\footnotetext{
${ }^{23}$ Ao afirmar que o castigo hegeliano ao autor de um delito sempre se fundará na necessidade de preservar a sociedade frente a quem decidiu cometê-lo, ROJAS acrescenta que "Hegel veía en la pena una retribución jurídica justificada por la necesidad de reparar al derecho con una violencia contraria que restableciese el orden legal violado" (ROJAS, 2000, p. 98-99).

${ }^{24}$ Sobre as possíveis variações da teoria absoluta da pena, VON HIRSCH aduz que "aunque actualmente en Alemania apenas si existen seguidores de las teorías absolutas es posible encontrar en la literatura un buen número de concepciones de este tipo. Una de ellas es la «retribución»: la realización del injusto fundamenta la obligación de imponer un mal al autor mediante el que debe «pagar». Otra concepción distinta es la teoría de la «ventaja injustificada»: quien ha convertido a otro en víctima, adquiere una ventaja injustificada frente a esta persona a través del provecho del autodominio de la obediencia al derecho, la función de la pena precisamente radica en imponerle una desventaja que compense esta situación. Una teoría más es la que persigue la confirmación del ordenamiento: desde este punto de vista todo delito significa un desafío al ordenamiento jurídico y la pena supone su afirmación reactiva." (VON HIRSCH, 2003, p. 126). FALCÓN y TELLA (2005, p. 152-153) dividem a teoria absoluta em quatro variantes principais. Na primeira, está o chamado "retribucionismo intrínseco", que parte do entendimento de que existe um bem intrínseco na imposição de sofrimento aos culpáveis. A segunda toma arrimo na ideia de restaurar o equilíbrio geral entre custos e benefícios, que foi alterado pela ofensa, ainda que simbolicamente se exija a submissão do sujeito a uma desvantagem para neutralizar a vantagem obtida ilicitamente. Quase semelhante ao tópico anterior, a terceira variante concebe a sanção como apta a anular o mal causado, restaurando o status quo ante e o equilíbrio social. Por último, encontra-se a reprovação relacionada com a denúncia, cuja existência fortalece a inibição frente ao delito e reafirma a identidade da sociedade.
} 


\section{a) Críticas a um autoritarismo retributivo}

Existem conhecidos méritos na teoria da retribuição, que convergem para o estabelecimento de parâmetros de proporção para a magnitude da pena, ${ }^{25}$ limitando o poder punitivo do Estado frente à culpabilidade. Contudo, nas palavras de ROXIN, "a teoria da retribuição já não se pode sustentar hoje cientificamente” (ROXIN, 1997, p. 82).

As teorias absolutas foram consideradas inadmissíveis sob a perspectiva da política criminal, na medida em que potencialmente justificam modelos não liberais de Direito Penal autoritário e máximo. ${ }^{26}$

A primeira e mais forte crítica à teoria absoluta, portanto, consiste em sua indiferença à finalidade do Direito Penal, de proteção subsidiária de bens jurídicos, ${ }^{27}$ porque a pena é entendida como instrumento desligado de qualquer fim social. DIAS (1999, p. 91-97), por exemplo, repudia a retribuição como uma função da pena, porque o fundamento da teoria absoluta é justamente a independência em relação a uma finalidade para a aplicação do castigo ao sujeito, de modo que este não seja utilizado de forma instrumental pela sociedade.

A atual concepção de Estado democrático de Direito não concebe uma instituição sancionadora, limitadora de valores e direitos humanos, que não busque um fim de proteção de bens jurídicos essenciais de relevância penal (DIAS, 1999, p. 94). Para essa vertente teórica, estabelecer penas desvinculadas de suas consequências sociais equivaleria à aceitação da arbitrariedade estatal, pois as autoridades seriam autorizadas a infligir males sem perseguirem fins utilitários.

\footnotetext{
${ }^{25}$ Cf. TORON (1996, p. 112): "Este modo de conceber a pena, conquanto soe duro porque a reação ao delito não tem finalidade alguma senão a de castigar, tem o mérito de preservar a dignidade do sentenciado. De fato, não se lhe poderá infligir para além do mal causado (ou, numa linguagem moderna, do bem jurídico ofendido) ou uma pena indefinida com vistas a um 'tratamento reeducativo' ou qualquer outro fim. A retribuição jurídica aparece aqui como uma importante garantia no que diz com a proporcionalidade da pena. Mas, por outro lado, tem-se realçado e criticado que as premissas teóricas, como, por exemplo, a culpabilidade em sentido tradicional e o livre arbítrio são indemonstráveis."

${ }^{26}$ Cf. GABRIEL IGNACIO ANITUA: "é certo que tanto Bentham quanto Kant também seriam utilizados - do mesmo modo que, de forma paradigmática, Smith - pelos ideólogos neoconservadores que assessorariam Reagan e Tatcher, entre outros governantes de direita, para apoiar sociedades desiguais e injustas". (2008, p. 791).

${ }^{27}$ Nesse sentido, esclarece ROXIN que "el Estado, como institución humana, no es capaz de realizar la idea metafísica de justicia ni está legitimado para ello. La voluntad de los ciudadanos le obliga a asegurar la convivencia del hombre en paz y en libertad; está limitado a esta tarea de protección. La idea de que se puede compensar o suprimir un mal (el delito) causando otro mal adicional (el del sufrimiento de la pena), sólo es susceptible de una creencia o fe, a la que el Estado no puede obligar a nadie desde el momento en que ya no recibe su poder de Dios, sino del pueblo.” (ROXIN, 1997, p. 82).
} 
Seguindo esse raciocínio, VON HIRSCH expõe que, ao contrário das teorias preventivas, os argumentos retributivos "não estão orientados às consequências, por isso seus conceitos se desprendem de postulados abstratos e verdades morais universais, distanciados da vida cotidiana. Eles frequentemente se identificam com a vingança ou com a ideia hegeliana de que o autor deseja seu próprio castigo" (VON HIRSCH, 2003, p. 125).

A compensação pela pena, embora seja um dos fundamentos mais importantes da teoria retributiva, não pode ser considerada isoladamente, principalmente porque, em uma reflexão kantiana, pressupõe uma plena liberdade da vontade. A premissa de autêntica liberdade de vontade parte de um plano ideal questionável na realidade. Sob esta perspectiva, não é possível diagnosticar com precisão se o homem, em determinado momento, poderia ou não atuar de modo diverso (ROXIN, 1997, p. 82). Assim, não estariam em funcionamento limites adequados ao poder punitivo do Estado, no sentido de que toda e qualquer conduta ilícita traria obrigatoriamente consigo uma sanção correspondente, independente do sujeito infrator e do contexto do delito.

Considerando que o castigo deveria retribuir o mal causado, não existe um paralelo perfeito, no mundo real, entre o bem retirado da vítima e o bem retribuído despojado do infrator. Esta disparidade, seja do ponto de vista de quem sofreu o dano, seja de quem o perpetrou, pode desembocar em uma nova injustiça, que pode ser compreendida, igualmente, como uma reparação assimétrica, gerando, segundo as palavras de KLAUS GÜNTHER (2006, p. 191) uma "série circular de conflitos sangrentos, sem tréguas e sem saídas". Ilustra GÜNTHER que:

A simples reparação com base no valor do bem atingido não é jamais capaz de compensar a vergonha, o aviltamento e a humilhação na medida, subjetiva e variável de caso para caso, em que a vítima as sofreu. E, por outro lado, uma retribuição levada a cabo de maneira especialmente ultrajante pode provocar na pessoa assim punida a conviç̧ão de ter, por sua vez, sofrido uma injustiça, a exigir reparação. (GÜNTHER, 2006, p. 191).

Não obstante as críticas, ultrapassada a irrealizável equiparação de talião, reconheceu-se que a pretendida igualdade do (i) bem subtraído com a infração e do (ii) bem subtraído do autor da infração - em retribuição - não poderia ser fática, mas normativa (entre delito e pena). A compensação estaria, portanto, estabelecida em função da culpabilidade do agente. Ainda que o moderno pensamento jurídico penal de orientação 
preventiva haja abandonado a versão pura da teoria absoluta, não abandonou a culpabilidade e a proporcionalidade como elementos centrais. ${ }^{28}$

\section{B) Função preventiva ou relativa}

Na linha oposta à apresentada acima, a teoria relativa da pena justifica a imposição da sanção criminal como um mal necessário para prevenir novos delitos (ne peccetur). Nesta concepção utilitarista e, portanto, consequencialista, ${ }^{29}$ o viés preventivo da pena se direciona ao futuro; seu objetivo é a obtenção de utilidades sociais futuras, com a redução dos delitos sobre os quais a pena pode recair.

O denominador comum das correntes que integram as teorias relativas é a ideia de que a pena serve como meio para a obtenção de fins socialmente úteis. Existe um reconhecimento de que a pena se traduz em um mal; contudo, ela configura igualmente um instrumento político-criminal necessário de profilaxia criminal.

As teorias relativas dividem-se entre as doutrinas da prevenção especial, que vinculam o fim preventivo à pessoa do infrator, e as doutrinas da prevenção geral, que o vinculam à generalidade dos cidadãos.

\footnotetext{
${ }^{28}$ MIR PUIG, ao defender a importância da proporcionalidade da pena em relação ao delito, afirma que a função da retribuição não pode mais fundamentar-se em um conteúdo religioso de justiça divina; assim: "Cabe fundamentar la exigencia de proporción entre el delito y la pena en la propia prevención, pero en su vertiente de prevención general positiva." (2009, p. 1361). Por esse motivo, muitos doutrinadores defendem a existência de uma única finalidade da pena, a de prevenção geral positiva. DIAS expõe esse posicionamento de inspiração germânica, fazendo referência à Stellenwertttheorie, traduzida por ele como "teoria do valor de posição." (2006, p. 68). Nesta mesma linha, entende COSTA (2008) que a função final do Direito Penal é a prevenção, mas que esta é alcançada por meio da aplicação de um mal, consubstanciado no aspecto punitivo inerente ao Direito Penal. Em outras palavras, a finalidade da pena, no Estado democrático de Direito, configura-se na prevenção por meio da punição estatal.

${ }^{29}$ Para VON HIRSCH (2003, p. 125): "Las justificaciones relativas de la pena tienen carácter consecuencialista, pues pretenden únicamente impedir la aparición de nuevos delitos. Esta es la finalidad más explícita de los conceptos de rehabilitación, intimidación o innocuización por lo que son igualmente relativos. La «prevención general positiva» constituye también un fin relativo. Así por ejemplo sus fines preventivo integradores pretenden fortalecer la conciencia normativa de los ciudadanos con el fin de asegurar la legalidad de sus comportamientos. En un Estado moderno, cuya finalidad última es asegurar las mejores condiciones de vida para sus ciudadanos, las teorías relativas se consideran con bastante frecuencia como el único modelo válido de pena."
} 


\section{a) Prevenção Geral}

A prevenção geral se fundamenta na função utilitária da intimidação geral como meio de prevenção do surgimento de futuros delitos na sociedade. O foco está na comunidade em geral, não nos sujeitos que já delinquiram, nem nos que possam eventualmente delinqüir (BARATTA, 1994, p. 21-22). ${ }^{30}$ A pena constitui, portanto, um instrumento político-criminal destinado a atuar psicologicamente sobre a generalidade dos membros da comunidade, com a afirmação de convicções jurídicas fundamentais. A prevenção geral postula que os indivíduos não realizarão condutas infratoras por medo de serem submetidos a uma pena aplicada pelo Estado. A sanção, em conclusão, não é considerada um castigo frente à infração, mas um instrumento dirigido a prevenir delitos futuros, com efeito inibidor, intimidatório e exemplificativo.

A prevenção geral atua não só com a cominação geral das penas, produzindo efeitos psicológicos, mas também com sua imposição e execução. ${ }^{31}$ A ameaça da lei se torna uma verdadeira ameaça à generalidade das pessoas quando efetivamente executada, momento em que a sociedade a vê como possível e aplicável. ${ }^{32}$

ROJAS (2000, p. 100) apresenta duas argumentações distintas para a prevenção geral, ainda que pareçam similares. Por um lado, sob a perspectiva da aplicação de medidas de coerção, recorre-se à eficiência dissuasória do exemplo oferecido com a imposição da pena, para que o ilícito manifeste-se como um mau negócio para o ofensor, dando-lhe motivos para se arrepender e dissuadir os demais. Por outro lado, em uma visão de adesão voluntária à norma, o raciocínio não reside no "caráter exemplificador da pena, mas de modo mediato através da ameaça contida na lei penal. Sob este ponto de vista, vê-

\footnotetext{
${ }^{30}$ Cf. BARATTA (1994, p. 21-22): "A função da pena não se dirige nem aos infratores atuais nem potenciais. Ela se dirige sobretudo aos cidadãos fiéis à lei, aos quais supostamente manifestam uma tendência em respeitá-la. Em relação a estes, a previsão ou aplicação das penas não tem a função de prevenir delitos (prevenção negativa), senão a de reforçar a validade das normas (prevenção positiva): isso significa também restabelecer a confiança institucional". Em sentido diverso, ROJAS destaca o destinatário da norma como aqueles potenciais autores: "Estas teorías suelen ser identificadas con el aspecto intimidatorio de las penas, pues su justificación se hallaría en la finalidad de evitar la comisión de delitos respecto de sus potenciales autores, quienes quedarían disuadidos al advertir la aplicación efectiva del castigo prometido" (ROJAS, 2000, p. 100).

${ }^{31}$ Com o exemplo do pai que castiga o filho com o objetivo de reprimir-lhe os impulsos não desejados, GIMBERNAT ORDEIG justifica o uso da pena "para reforçar aquelas proibições cuja observância é absolutamente necessária, para evitar, na maior medida possível, a execução de ações que atacam as bases da convivência social, para conferir enfim a tais proibições - com a ameaça e com a execução da pena quando não sejam respeitadas - um especial vigor que eleve na instância da consciência seu efeito inibidor" (GIMBERNAT ORDEIG, 2004, p. 17).

32 "Se entende que a cominação penal deve intimidar e a execução penal deve confirmar a seriedade da ameaça" (ROJAS, 2000, p. 100).
} 
se na lei o resto dos integrantes da sociedade, a quem se pretende desalentar na comissão de delitos e convencê-los de que é preferível não delinquir” (ROJAS, 2000, p. 100).

A prevenção geral pode ser entendida sob duas formas: a prevenção geral negativa ou de intimidação e a prevenção positiva ou de integração.

\section{Prevenção geral negativa ou de intimidação}

$\mathrm{Na}$ prevenção intimidatória, a principal característica é a reafirmação da efetiva vigência das normas por meio da coação psicológica sobre os cidadãos exercida pelo Estado, cuja eficácia se apóia na aplicação de "punição exemplar". Presente nos postulados de Grocio, Hobbes, Locke, Pufendorf, Thomasius, BeCCARIA, Bentham, tal "punição exemplar" permeou o pensamento jusnaturalista dos séculos XVII e XVIII (ROJAS, 2000, p. $100)$.

A prevenção geral negativa foi desenvolvida por PAUL JOHANN ANSELM RITTER VON FEUERBACH, que, em sua "teoria psicológica da coação", 33 considerava o sujeito preso em um "campo de batalha" (ROXIN, 1997, p. 88), entre as tentações da prática do injusto e a vontade de manter-se fiel às normas. Nessa situação, a finalidade do Direito Penal seria "provocar na psique do indivíduo indeciso sensações de desagrado, que fizessem prevalecer os esforços de impedir a comissão delitiva e, dessa maneira, pudessem exercer uma 'coação psíquica' para induzi-lo a se abster da comissão do fato" (ROXIN, 1997, p. 88). Segundo a prevenção geral negativa, a pena serve como desestímulo por causa do temor que suscita, representando uma verdadeira ameaça legal.

Para VON FEUERBACH, o conhecimento seguro de que a comissão do fato criminoso traz consigo um mal inevitável pode servir de impulso para suprimir a conduta contra o Direito, considerando que esta desvantagem é maior do que os benefícios da prática delitiva. Ao conectar o fim de pena com a prevenção do delito por meio da mera intimidação dos cidadãos pela lei, cria-se uma teoria de intimidação e, por isso, a concepção de prevenção geral negativa.

\footnotetext{
${ }^{33}$ Ou teoria da coação psicológica, segundo $\operatorname{ROXIN}(1997$, p. 88).
} 


\section{Prevenção geral positiva ou de integração}

Na chamada prevenção geral positiva, atribui-se à pena a função de integração social, obtida em decorrência de um reforço de fidelidade ao ordenamento jurídico, bem como a promoção do conformismo por parte dos cidadãos frente ao Estado.

Em consequência, a prevenção geral positiva concebe o Direito Penal como uma afirmação das convicções jurídicas fundamentais, voltado a reforçar a convicção coletiva sobre a vigência das normas e a promover laços de confiança institucional no Direito, recordando a validade das normas como contraposição ao delito.

Para WELZEL (2001), o Direito Penal persegue um estado de consciência jurídica do cidadão, de contínua fidelidade ao Direito; a pena, nesse esteio, auxilia na formação do juízo ético-social dos cidadãos.

Uma variante limitadora ${ }^{34}$ da teoria da prevenção geral positiva pretende estabelecer parâmetros que restrinjam as consequências excessivas do poder punitivo. MIR PUIG, fazendo referência a HASSEMER e a ARMIN KAUFMANN, afirma que "uma corrente doutrinária sustenta que esta prevenção não deve buscar a pura intimidação negativa (ou seja, inibidora da tendência de delinquir), mas também a afirmação positiva do Direito Penal, como afirmação das convivências jurídicas fundamentais da consciência social da norma, ou da atitude de respeito pelo Direito" (MIR PUIG, 2007, p. 92).

Nesta linha de raciocínio, a pena ganha justificação a partir da necessidade de proteção de bens jurídicos. A sanção apresenta perfil positivo e integrado, no qual a intimidação atua somente dentro de um parâmetro limitado por diretrizes culturais, por standards ou modelos ético-sociais de comportamento, a fim de conservar ou reforçar a ordem jurídica (DIAS, 2006:59).

Por outro lado, a vertente fundamentadora, inspirada nas ideias sistêmicas de NIKLAS LUHMANN e defendida por GÜNTHER JAKOBS, simpatiza com a noção de proteção das condições da interação social por meio da pena, que assume, portanto, uma função preventiva integradora. ${ }^{35}$ Para JAKOBS, o ordenamento representa a identidade da

\footnotetext{
${ }^{34}$ Conceituando o termo prevenção limitada, MIR PUIG explica que: “en este modelo de Estado la pena habrá de ser necesaria para la preservación de delitos, pero al mismo tiempo deberá someterse a límites relacionados con los derechos de los acusados. Deberá tener una función de prevención limitada.” (2009, p. 1360).

${ }^{35}$ Segundo ANITUA, "surge, assim, uma teoria da pena que se pretende nova, embora seja, outra vez, uma rara mistura de idéia hegelianas e de defesa social, rodeada por um novo discurso, de difícil compreensão. Essa teoria é a da 'prevenção-integração', que derivaria em uma dupla função da pena: a 'latente', de consolidação da sociedade; e a 'manifesta', de marginalização do fato delitivo e do seu autor' (2008, p. 800).
} 
sociedade. A pena contribui, por conseguinte, para confirmar essa identidade social, com o reconhecimento e manutenção da vigência da norma. Em outros termos, "a confirmação da identidade da sociedade é exatamente o mesmo que a manutenção da vigência da norma" por força da pena (CANCIO MELIÁ e FEIJOO SÁNCHEZ, 2006, p. 49). Do sistema penal resultaria uma fidelidade ao Direito por parte dos membros da sociedade.

Considera-se que o Direito está em vigor na medida em que exerce sua orientação comunicativa direcionada à prevenção de delitos. E se assim não obtém êxito, o Direito igualmente se realiza com a conduta antijurídica e a reação frente ao injusto, visto que "quando se sanciona com o Direito, o ataque fica repudiado, a tendência lesiva é eliminada e a norma segue sendo real, quer dizer, segue em vigor" (JAKOBS, 2006, p. 138).

Nas palavras do próprio $J A K O B S$ :

O delito é uma ameaça à integridade e à estabilidade sociais, enquanto constiui a expressão simbólica de uma falta de fidelidade ao Direito. Esta expressão simbólica faz estremecer a confiança institucional e a pena é, por seu turno, uma expressão simbólica oposta à representada pelo delito. Como instrumento de prevenção positiva, ela tende a restabelecer a confiança e a consolidar a fidelidade ao ordenamento jurídico, em primeiro lugar em relação a terceiros e, possivelmente, também em relação ao autor da violação. (JAKOBS, 1997, p. 6).

A construção jurídica desenvolvida por $J_{A K O B S}$ de salvaguarda da vigência da norma pela imposição de pena, "como contradição da negação da vigência por parte do infrator" (JAKOBS, 2006, p. 141), aproxima-se, em certa medida, da visão retributiva hegeliana, ${ }^{36}$ ainda que com ela não se confunda. ${ }^{37}$

ABEL SOUTO destaca três efeitos que a pena exercita no pensamento de JAKOBS: a confiança na norma, a fidelidade ao Direito e a aceitação das consequências jurídicas (ABEL SOUTO, 2006, p. 38-39).

Sem fazer referência a $J A K O B S, \operatorname{ROXIN}(1997$, p. 89-90) enumera, além do efeito intimidatório da pena para reforçar a confiança jurídica, outros efeitos: "o efeito de aprendizagem, motivado social-pedagogicamente; o exercício na confiança do Direito, que

\footnotetext{
${ }^{36}$ Cf. CANCIO MELIÁ e FEIJOO SÁNCHEZ (2006, p. 49): "Su teoría comunicativa no supondría nada distinto que una trasposición del concepto hegeliano de pena al presente, con un nuevo revestimiento funcional y con una concepción más moderna y liberal del Estado que la mantenida por HEGEL. JAKOBS ha conseguido fusionar bajo estos parámetros a HEGEL y a LUHMANN en una teoría muy personal".

${ }^{37}$ Com a mesma conclusão, SILVA SÁNCHEZ dita que "no tendría por qué sorprender que JAKOBS cite a favor de su concepción las tesis de HEGEL, ni que Arthur KAUFMANN califique la tesis de JAKOBS de retributiva. Por lo que ocurre, probablemente, no es que JAKOBS sea 'retribucionista' en el sentido clásico del término, sino que la retribución, perdido su anclaje en los ideales de justicia absoluta, puede haberse ido convirtiendo progresivamente en una concepción preventiva-integradora" (SILVA SÁNCHEZ, 2002, p. 205).
} 
se origina na população pela atividade da justiça penal; o efeito de confiança que surge quando o cidadão vê que o Direito se aplica; e, finalmente, o efeito de pacificação, que se produz quando a consciência jurídica geral se tranquiliza, em virtude da sanção, sobre o desrespeito à lei e considera solucionado o conflito com o autor” (ROXIN, 1997, p. 89-90).

\section{Críticas à instrumentalização do homem}

O primeiro problema que subsiste na teoria da prevenção geral positiva é o de que a pena abstratamente cominada converte o infrator individual "em objeto de demonstração no interesse do bom comportamento de outros", ao fazê-lo constituir um exemplo para dissuadir o delito (HASSEMER, 1984, p. 380-381). Ocorre inevitavelmente, pois, a temida instrumentalização do homem descrita por $K A N T$, e reputada como atentatória à dignidade humana, ${ }^{38}$ porque, ao se aplicar uma pena exemplar aos demais, utiliza-se do condenado para alcançar fins que não têm relação consigo ou com sua conduta.

Aqui, e em todas as outras teorias, apresentam-se problemas empíricos. ${ }^{39} \mathrm{~A}$ ausência de informações e pesquisas sobre a eficiência das penas na realidade social é um problema de difícil solução. Com isso, os estudiosos das penas em geral esgrimem raciocínios teóricos para abordar o tema da prevenção.

No caso da teoria da prevenção geral positiva, para que se produzam os efeitos intimidatórios desejados, há a presunção de que os destinatários da norma a conheçam, com prévio domínio dos fatores que se desencadeariam com o delito. Essa suposição não é possível sequer com relação às normas sociais, internalizadas pelos costumes; é ainda fictícia, principalmente, por tratarem de temas que nem sempre são próximos ao cotidiano dos cidadãos, que não têm conhecimento pleno das normas jurídico-penais, criadas pelo legislador.

\footnotetext{
${ }^{38}$ Cf. ROXIN (1997, p. 91): “Asimismo, la objeción de que un castigo con fines preventivos atenta contra la dignidad humana tiene más peso en la prevención general que en la prevención especial. Es decir, mientras la resocialización debe ayudar (por lo menos también) al condenado, el castigo por motivos de prevención general sólo pesa sobre el autor por motivo de la comunidad (o sea, de otro) y la facultad para ello requiere una justificación que esta teoría no puede ofrecer por sí misma".

${ }^{39}$ Sobre a comprovação empírica, expressa GÜNTHER que a dificuldade não está só na obtenção de dados, mas reside, na realidade, na possibilidade de obtê-los. Assim: "freqüentemente levantam-se dúvidas sobre a possibilidade de se provar empiricamente a alegada relação de meio e fim entre comportamento lícito e pena intimidatória. Até o momento não existe certeza de que a pena tenha realmente um efeito intimidatório" (GÜNTHER, 2006, p. 193).
} 
Porém, mesmo que estas normas fossem plenamente conhecidas, a teoria supõe um infrator potencial "neutro", homem ideal dotado de racionalidade e capacidade de cálculo estáveis (homo oeconomicus), apto e disposto a ponderar os benefícios e prejuízos de seu ato - motivado, pois, a comportar-se conforme o Direito. ${ }^{40}$

ROXIN (1997, p. 89) acrescenta que pouco importa a magnitude da ameaça das penas aos sujeitos com tendência à criminalidade, cuja preocupação efetiva está na “dimensão do risco de serem pegos" - em outras palavras, no medo de serem descobertos. Por esse motivo, a prevenção geral poderia ser efetiva não com a agravação das penas, mas com um melhor preparo da investigação penal, que garanta mais efetividade e intensificação na certeza da punição. Quanto maior a probabilidade de a conduta não ser descoberta, menor será a probabilidade do efeito intimidatório da ameaça penal (GÜNTHER, 2006, p. 193).

\section{Crítica à tutela da confiança geral na validade e vigência das normas do ordenamento jurídico}

A crítica principal à teoria preventivo-geral provém da consideração de que ela não estabelece limites ao poder punitivo e "não impede o terrorismo penal legislativo" (FERRAJOLI, 2006, p. 260), porque a pena, para fixar a coação psicológica, obtém maior eficácia quanto mais elevadas e severas são as sanções cominadas. As teorias gerais positivas ou negativas não preveem medidas de delimitação de duração da pena. Persiste a ideia de que "penas mais altas e mais duras tenham um maior efeito intimidatório, [o que] tem sido historicamente (apesar de sua provável inexatidão) a razão mais frequente de penas 'sem medida"' (ROXIN, 1997, p. 91).

O expansionismo penal dirige-se a este movimento, no qual existe cada vez mais ampliação de penas, quer com a criação de novos crimes, quer com incrementos na punição aos já existentes.

\footnotetext{
${ }^{40}$ Cf. ANITUA, "isso remete ao absurdo de se crer que a conduta humana, que toda conduta humana de cada um dos diferentes seres humanos, se guiaria sempre pela escolha 'racional' entre o 'custo' do castigo e o 'benefício' de delito, definidos, os três conceitos entre aspas, pelas avaliações dos funcionários estatais e criminólogos universitários. As referências desse modelo economicista aos valores de tempo e dinheiro, próprios dos setores mais privilegiados da sociedade estatal-capitalista, demonstram o quanto ele tem de imperialismo cultural." (2008, p. 794).
} 
Esse panorama indica uma ausência de justificativas sólidas para os meios preventivos, pois representa uma porta aberta, sem os freios do princípio da culpabilidade ou de um critério de proporcionalidade que iniba o exercício imperativo do poder estatal. A carência de limites à gravidade da pena cominada leva a uma política criminal de "terror". ${ }^{41}$ Além disso, a incitação ao terrorismo penal não é comprovadamente eficaz; argumenta-se, por exemplo, que em geral o sujeito não deixa de cometer delitos em função da ameaça penal, mas somente em razão de valores previamente internalizados. ${ }^{42}$

Uma crítica relevante sobre a intimidação à coletividade, expressa por ROXIN, sinaliza que a teoria preventivo-geral não dá impulso à execução da pena. A preocupação dos teóricos em regra restringe-se à cominação abstrata da pena, dando-se pouca relevância à sanção penal efetivamente imposta ao infrator (1997, p. 92).

Embora se considere uma versão de prevenção geral positiva nos modelos penais atuais, vinculados aos princípios da dignidade humana, formalização e ultima ratio, continua sendo próprio desta teoria a valorização da confiança na validade da norma, sem que haja necessidade de afligir com o mal; a teoria preventiva, nestes moldes, resume-se a mero meio de comunicação (GÜNTHER, 2006, p. 201). ${ }^{43}$

Especificamente sobre o pensamento de JAKOBS, a preocupação da doutrina desponta para o afastamento da proteção dos bens jurídicos, ao considerar unicamente a lealdade ao Direito. São os efeitos reflexos a terceiros que determinam, na prevenção geral negativa, a quantidade e a severidade da pena, a depender da necessidade da demanda por prevenção (GÜNTHER, 2006, p. 192).

Essa abstração impede que os princípios regentes do Direito Penal de um Estado de Direito democrático constituam uma limitação à prevenção geral, uma vez que não se

\footnotetext{
${ }^{41}$ MIR PUIG ressalta uma tendência ao terror estatal com a utilização sem limites da prevenção geral (2007, p. 92).

${ }^{42}$ Cf. TORON (1996, p. 113): "A função motivadora da norma penal só pode ser eficaz se for precedida, ou acompanhada, de outras instâncias de controle social, isto é, quando dentro dos processos de socialização primária (casa, escola, clube, instituição religiosa, etc.) e, depois, da vida associativa, enraízam-se regras morais e sociais que nos tornam cumpridores da lei não pela ameaça da pena, mas em razão dos valores internalizados".

${ }^{43}$ Tratando da função comunicativa da pena, GÜNTHER questiona-se: "Por que tais mensagens precisam ser comunicadas justamente por meio da pena permanece uma questão em aberto. Seu conteúdo proposicional poderia ser comunicado também por intermédio de outros atos performativos, como uma condenação em um processo público e formalizado de determinação dos fatos e de imputação. $\mathrm{O}$ nexo entre a mensagem mediada pela comunicação e o meio de comunicação pena continua contingente; não está comprovada a existência de uma relação necessária. Apenas se e na medida em que os destinatários da norma já tenham aprendido a linguagem da pena é que podem compreender as mensagens transmitidas dessa forma e tornarem-se incapazes de imaginar qualquer outra linguagem para a transmissão da mensagem." (GÜNTHER, 2006, p. 201).
} 
assenta na proteção de bens jurídicos. Nesse sentido, MIR PUIG exemplifica que, em casos extremos, delitos menos graves, que se repetem continuamente, poderiam receber sanções elevadas, para contraestimular a frequência de sua realização pela sociedade. De maneira inadmissível na ótica garantista, o Direito Penal buscaria impor uma reação social ainda não estabelecida ao injusto previsto na norma. Os ilícitos mais graves, por sua vez, seriam castigados com penas mais leves, por conta de sua frequência reduzida, que denotaria uma desaprovação social eficaz (MIR PUIG, 2007, p. 93). ${ }^{44}$

Tal situação, comandada por considerações pragmáticas e de eficiência, transformaria a pena em instrumento de modelagem social, em detrimento da dignidade humana. ${ }^{45}$

\section{b) Prevenção Especial}

Se, por um lado, a pena atua de forma geral sobre toda a comunidade na prevenção geral, na prevenção especial ela se volta especialmente sobre o condenado, ou seja, sobre quem já delinquiu (ROXIN, 1997, p. 87). Sua finalidade precípua, portanto, é a prevenção da ocorrência de novos delitos pelo mesmo infrator - a reincidência.

As teorias da prevenção especial ganharam destaque com a cultura penalógica da segunda metade do século XIX e do século $\mathrm{XX}^{46}$ (MIR PUIG, 2007, p. 94), que analogiza o delito a uma doença e a pena a uma cura, na forma de tratamento político-jurídico (FERRAJOLI, 2006, p. 251).

\footnotetext{
${ }^{44}$ Seguindo o mesmo raciocínio, GÜNTHER exemplifica a distorção da teoria ao tratar de delitos culposos: "Nesta linha, todos os delitos para os quais há uma grande demanda por prevenção (como os delitos de trânsito, que ocorrem de forma massiva) deveriam ser punidos de maneira mais rigorosa do que os delitos graves, que são muito mais raros. Além disso, importariam menos o tipo e grau da culpa do autor do ilícito. Importaria mais a conduta violadora da norma como acontecimento externo, assim como o dano por ela causado. Se ilícitos culposos ocorrem com maior freqüência e provocam danos maiores do que os ilícitos dolosos, então estes deveriam ser punidos de forma mais branda do que aqueles. No entanto, na medida em que penas preventivas se afastam da conduta e da culpa do autor do ilícito, para criar apenas efeitos intimidatórios, elas se tornam injustas em relação a ele." (GÜNTHER, 2006, p. 192).

${ }^{45}$ SILVA SÁNCHEZ assinala que "en su versión más radical, las nuevas doctrinas condujeron a la sustitución de las penas por medidas de seguridad o de corrección, no sujetas a los límites tradicionales de la pena (especialmente, el principio del hecho, la proporcionalidad, la culpabilidad), sino atentas tan sólo a la constatación de la peligrosidad en el sujeto." (SILVA SÁNCHEZ, 2002, p. 27).

${ }^{46}$ Sobre os precedentes históricos, ver FERRAJOLI (2006, p. 246-255).
} 
Sob o ponto de vista preventivo-especial, justifica-se unicamente aquela pena que é necessária para obstaculizar a reincidência de cada autor em concreto. Não se pretende retribuir o fato passado: reduz-se o fim da pena a prevenir novos delitos do autor.

Segundo FERRAJOLI (2006, p. 246-251), as vertentes da prevenção especial que buscaram justificar a aplicação da sanção penal como tratamento - as doutrinas moralistas de emenda das poenas medicinalis, as terapêuticas naturalistas de defesa social, e as teleológicas de diferenciação da pena - sublinharam o sujeito infrator a ser transformado pela pena, dando menos ou nenhum destaque ao fato por ele cometido.

Neste trabalho, destaca-se a exposição do programa de Marburgo de diferenciação das penas. FRANZ VON LISZT (1995), expoente da escola jurídico-penal sociológica na Alemanha, partindo de um conceito de pena final justa, correta e necessária ao caso concreto, distinguiu as categorias de infratores com base em sua personalidade. ${ }^{47}$ Para cada perfil de infrator determinou diferentes formas de atuação jurídico-penal, que variavam entre a intimidação do mero infrator ocasional - passível de ser inibido a cometer posteriores delitos - e a correção ou socialização do infrator não ocasional, mas corrigível, ou, nos casos mais radicais, seu isolamento mediante a clausura para inocuização do infrator habitual (não passível de correção ou intimidação) (MIR PUIG, 2007, p. 94-95; ROXIN, 1997, p. 84).

Este modelo de instrumento "flexível e polifuncional" (FERRAJOLI, 2006, p. 249) de variação de medidas aplicáveis aos infratores ocasionou uma divisão didática entre prevenção especial positiva ou de correção, destinada à readaptação, reinserção e ressocialização do infrator para que, com intenção e capacidade, respeite as leis após um tratamento individualizado; e prevenção especial negativa de intimidação ou inocuização, compreendida como a eliminação ou neutralização do infrator, visto como despreparado para a convivência social.

Distinta da prevenção especial negativa, a ideia da socialização por meio de recursos pedagógicos e sociais, baseada na prevenção especial positiva, desencadeou uma série de modificações legislativas (ROXIN, 1997, p. 84-85), nas quais se evidenciava o princípio do Estado social, cujo escopo era proteger o indivíduo e a sociedade, ao mesmo tempo em que se visava à reintegração do autor, sem expulsá-lo ou rotulá-lo como delinquente.

\footnotetext{
${ }^{47}$ Os condenados eram considerados como: infrator ocasional, infrator não ocasional mas corrigível, infrator habitual incorrigível, segundo exposição de MIR PUIG (2007, p. 95).
} 


\section{Crítica à sanção penal de duração indeterminada}

A hipótese de manter um sujeito preso por tempo incerto, até que ele esteja completamente apto para a reinserção na sociedade, pode significar uma privação de liberdade eterna. ROXIN (1997, p. 86) critica o princípio da pena personalizada e diferenciada por esta falta de medida para o poder punitivo, indicando casos em que a pena não se demonstra convergente com os ditames do Estado democrático de Direito, por se fundar exclusivamente na personalidade do autor, sem proporcionalidade com o fato delitivo.

A prevenção especial positiva espera que o condenado, de modo reflexo, deixe de cometer novo delito. A avaliação da relação vantagem-desvantagem de delinquir, isto é, o cálculo estratégico sobre condutas futuras, seria potencializada pela experiência dos custos da pena. Como exposto nas críticas à prevenção geral, os autores dos injustos penais não realizam esse comportamento racional, especialmente se existem outros fatores sociais que os inclinam à delinquência. ${ }^{48}$

Ademais, considerando a pena como flexível, variável segundo a personalidade do sujeito, as sanções penais ajustadas ao infrator podem desencadear um sistema de punição sem proporção, que não se baseia na conduta ilícita praticada, no tipo e grau de culpa. Pretere-se, portanto, o Direito Penal do fato, em favor do Direito Penal do autor (GÜNTHER, 2006, p. 194), que tolera sanções extremamente díspares a sujeitos que praticaram o mesmo injusto penal.

Ainda, a alternativa da prevenção especial mostra-se inapta à justificação do Direito Penal, dado que não apresenta resposta satisfatória nos casos de autores de delitos que não necessitam de ressocialização, como os autores de fatos culpáveis, pequenos delitos ocasionais ou injustos irrepetíveis, que não são passíveis de reincidência (ROXIN, 1997, p. 87).

Questiona-se, inclusive, se o Estado, na atividade de "pedagogo", "tutor" ou “terapeuta" (FERRAJOLI, 2006, p. 252), tem legitimidade para manipular a consciência individual dos cidadãos, em um dirigismo intelectual, ao impor determinados valores morais previstos na norma, para o regresso a uma sociedade naturalmente criminógena

${ }^{48}$ GÜNTHER afirma que a probabilidade de comportamento irracional aumenta de forma proporcional à gravidade do delito e que "a maioria dos homicídios ocorre no contexto de conflitos dramáticos de relacionamento, tendo os envolvidos se enredado em uma situação sem saída. As informações relevantes sobre outras possibilidades de conduta, alternativas para a solução de conflitos, menos custosas e com isso mais úteis, necessárias para uma escolha racional, faltam ao autor do ilícito justamente nas situações pesadas, tensas e sem saída." (GÜNTHER, 2006, p. 195). 
(SILVA SÁNCHEZ, 2002, p. 31). Pondera FERRAJOLI que as ideologias correcionalistas rompem princípios essenciais como a liberdade, a autonomia da consciência ${ }^{49}$ e a igualdade, ao tratarem o infrator como "anormal e inferior" (FERRAJOLI, 2006, p. 253) e ao implantarem projetos impositivos de alteração de personalidades "corrompidas". 50

Mesmo supondo que o condenado seja receptor voluntário das medidas de ressocialização, o que é raro, não é certo que uma aparente internalização dos valores sociais signifique sua readequação social; poderia tal modificação de comportamento fazer parte de um plano estratégico do condenado, com o fito de obter vantagens na execução penal e antecipar sua saída à liberdade, mesmo que para a prática de novos delitos (GÜNTHER, 2006, p. 198).

Por fim, a derrocada da credibilidade da lógica da ressocialização adveio da realidade dos sistemas de privação de liberdade, que carregam a contradição da impossibilidade de uma educação para a liberdade, com o intuito de reinserir o autor na sociedade, forjada com medidas de ausência de liberdade e distanciamento de qualquer contato social - que grosso modo estimulam a não ressocialização, quando não ocasionam verdadeiros danos de personalidade por isolamento (SILVA SÁNCHEZ, 2002, p. 30).

A experiência da prisão por um longo período de tempo imprime no condenado uma sensação de indiferença, embrutecimento e perda de identidade social, em paralelo à aquisição de valores e atitudes próprios do sistema carcerário; em outras palavras, as tentativas conhecidas de ressocialização em regra conduzem a sua antítese: a formação de uma identidade delinquente (GÜNTHER, 2006, p. 195).

\footnotetext{
${ }^{49}$ Cf. CARRARA (1956, par. 611) a pena "se estende a algo que não prejudica aos outros, abrindo estrada às mais sórdidas tiranias, e conferindo ao Estado os poderes que indevidamente se atribuem ao superior de um claustro. Seduz os ânimos a perspectiva da melhoria da humanidade, mas, quando, para alcançá-la, usam-se meios violentos, desnecessários para a defesa alheia, a aparente filantropia se degenera em um despotismo iníquo."

${ }^{50}$ Sobre as três orientações da prevenção especial, pondera FERRAJOLI que "cultivam um programa comum que, de maneira iníqua, concorda com as suas premissas éticas, deterministas, ou pragmáticas, vale dizer, o uso do direito penal não apenas para prevenir delitos, mas também para transformar as personalidades desviantes por meio de projetos autoritários de homologação ou, alternativamente, de neutralização das mesmas mediante técnicas de amputação e de melhoria social” (2006, p. 247).
} 


\section{C) Teorias unificadoras, ecléticas ou mistas}

As explicações unidimensionais ou monistas de justificação da pena resultaram em certa medida incompletas, ainda que primassem pela consistência lógica (SILVA SÁNCHEZ, 2008a, p. 2). Consequentemente, surgiu um grupo de teorias que visa a combinar os elementos legitimadores das teorias absolutas e relativas, de modo que a pena busque um resultado ao mesmo tempo útil e justo, que retribua proporcionalmente o mal culpável do delito além de perseguir fins preventivos gerais e especiais.

VON HIRSCH (2003) desenvolveu ideias sobre o duplo fim da pena: uma perspectiva de justificação da censura própria da pena, voltada para o passado, objetiva estabelecer a punição merecida, ao passo que, com olhar em direção ao futuro, vislumbra-se a pena também como instrumento preventivo, que se impõe ao infrator como se imporia a quaisquer outros infratores.

No que se refere às teorias unificadoras, destaca-se o pensamento da "teoria dialética da união" de ROXIN, que atribui fins distintos à pena, segundo momentos determinados, para além da mera justaposição dos fins das penas como outrora descritos pelas teorias retributivas e preventivas. Na cominação penal abstrata (fase legislativa), a pena deve ter a função de proteger bens jurídicos, associando-se aos preceitos da prevenção geral. Não poderia ser diferente, visto que este momento precede a conduta de um sujeito concreto, ao qual não se podem impor reações retributivas ou preventivoespeciais. Em um segundo momento, de determinação judicial da pena (individualização judicial), baseada ainda na prevenção geral, o juiz, ao impor a pena in concreto, reafirma a ameaça legal e atenta ao limite estabelecido pela culpabilidade, como um dos aspectos da retribuição. Desse modo, escapa-se do indesejado terror penal. Na construção "dialética", a culpabilidade, à diferença da teoria retributiva, não é o fundamento da pena, mas representa o limite ao poder punitivo. Por fim, no momento de execução da pena, deve terse em conta o fim preventivo-especial de ressocialização do autor, limitado aos parâmetros anteriores, privilegiando a reincorporação do infrator à sociedade.

REALE JÚNIOR expõe que "a pena, sob o viés de sua finalidade, é multifacetada, tem uma fisiologia complexa, pois se apresenta como coação psicológica dotada de objetivo intimidativo, sendo assim visualizada pelos indivíduos e pela sociedade. [...] A pena tem por fim retribuir com um mal a ação negativa contra um valor positivado pela lei. A lei é, portanto, uma retribuição jurídica confirmadora de um valor reconhecido como positivo e 
que foi desrespeitado pela ação delituosa.” (2009, p. 54-57). Neste sentido, a pena, apesar de ser um mal imposto, visa à reafirmação de um valor consagrado pela lei.

A teoria unificadora é vista como a mais adequada no contexto jurídico-penal contemporâneo, ${ }^{51}$ uma vez que visa, a um só tempo, a evitar os excessos unilaterais do poder punitivo e a dirigir os diversos fins das penas para vias socialmente construtivas, alcançando o equilíbrio dos princípios, por meio de restrições recíprocas.

Herda todas as críticas anteriores a "teoria aditiva", que se limita a unir finalidades das penas com exigências conflitivas, levando tanto os pontos positivos dos posicionamentos, bem como os pontos negativos. Entretanto, a "teoria dialética", melhor edificada, ao utilizar a culpabilidade como parâmetro para o poder de punir, contamina-se da inesgotável discussão sobre seu conteúdo, dimensão e apuração. ${ }^{52}$

\section{II.5. Notas sobre as finalidades das penas no Direito Penal moderno}

Após a análise das teorias tradicionais que objetivam dar um sentido à pena estatal, observa-se que nem as absolutas ou retributivas, nem as relativas ou preventivas, em sua vertente de prevenção geral ou de prevenção especial, são capazes de atender aos objetivos do Direito Penal em um Estado democrático de Direito, direcionado à promoção de dignidade humana.

Uma crítica da qual nenhuma teoria conseguiu desvencilhar-se é a ausência de fundamentação empírica, seja por carência de estudos, seja pela dificuldade de obter respostas satisfatórias, tendo em conta a multiplicidade e o entrelaçamento das variáveis incidentes sobre as condutas delitivas.

Conclui PERALTA, sobre as justificativas do discurso oficial sobre as finalidades das penas, que "estas abarcam desde a ilegitimidade teórica de seus diferentes fins até sua

\footnotetext{
${ }^{51}$ Em resumo, DIAS (1999, p. 135) defende que "1) Toda pena serve a finalidades exclusivas de prevenção, geral e especial. 2) A pena concreta é limitada, no seu máximo inultrapassável, pela medida da culpabilidade. 3) Dentro deste limite máximo ela é determinada no interior de uma moldura de prevenção geral de integração, cujo limite superior é oferecido pelo ponto ótimo de tutela dos bens jurídicos e cujo limite inferior é constituído pelas exigências mínimas de defesa do ordenamento jurídico. 4) Dentro desta moldura de prevenção geral de integração, a medida da pena é encontrada em função de exigências de prevenção especial, em regra positiva ou de socialização, excepcionalmente negativa ou de intimidação ou segurança individuais".

${ }^{52}$ Sobre a evolução histórico-dogmática da categoria de culpabilidade, MIR PUIG (2007, p. 522-538). Uma análise crítica em SCHÜNEMANN (1991).
} 
carência de fundamento empírico, muito embora a crítica se centre no fato de que nem sempre se determina previamente, nos discursos, quais são os objetivos que se pretende lograr com a pena" (2008, p. 4).

Como descrito no início deste capítulo, houve ao longo do tempo um complexo desenvolvimento dos fins da pena, com variações conectadas a diferentes modelos de Estado. Atualmente, frente às constantes modificações legislativas destinadas a acompanhar os anseios da sociedade moderna globalizada, ${ }^{53}$ o Estado democrático de Direito se depara com um abandono das conhecidas teorias retributiva e preventiva, utilizando-as tão-somente como meio retórico de camuflar outros fins não declarados, chamados por GÜNTHER (2006, p. 202) de “discurso extraoficial”.

A inflação de leis penais ${ }^{54}$ e o aumento das sanções penais levam ao abandono do caráter instrumental tradicional da pena, ou seja, a proteção dos bens jurídicos. As teorias das penas já receberam críticas contundentes, substancialmente pela dificuldade de comprovação empírica de possíveis colocações teóricas, pelo seu alcance restrito, vez que mormente destinadas ao âmbito acadêmico, ou por limitarem a pena a mero meio de comunicação de valores atuais. ${ }^{55}$

A postura preventivo-geral, que adquiriu nos últimos anos mais credibilidade, principalmente conciliada com a proteção de bens jurídicos essenciais, conduz a um radicalismo, com a antecipação de barreiras de proteção, com previsões de riscos e atuação antes da produção de lesão. Existe assim uma valorização da perspectiva simbólica ${ }^{56}$ da aplicação das penas, cujo objetivo é a adoção de um modelo próximo da prevenção geral integrativa ou positiva, no qual o prioritário se converte em "exercitar o reconhecimento da

\footnotetext{
${ }^{53}$ GÜNTHER indica algumas das impressões da população em relação às penas: "Que as penas deveriam ser mais freqüentes e duras, que a criminalidade aumenta drasticamente, que o Estado e a sociedade pouco fazem para combatê-la, que o sistema de justiça criminal se preocupa demasiadamente com o autor do ilícito e o trata de um modo excessivamente frouxo, enquanto as vítimas são abandonadas à sua sorte lastimável: hoje em dia existem poucas pretensões e convicções aceitas de modo tão amplo e abrangente pela população da Europa ocidental e da América do Norte como essas" (2006, p. 187).

${ }^{54}$ DOTTI (2001, p. 36) destaca que a inflação legislativa pode trazer "duas perspectivas bem definidas: a massificação da responsabilidade criminal e a erosão do sistema positivo. Ambos esses aspectos são demonstrativos da ausência de uma Política Criminal definida em nível de Governo".

${ }^{55}$ Sobre as críticas, conclui GÜNTHER (2006, p. 201-202) que "as razões e justificativas apresentadas no discurso oficial e público sobre a pena não resistem, portanto, a um exame mais detalhado. As alegadas relações de meio e fim entre a pena e seus efeitos não são acertadas ou são impossíveis de se comprovar, ou a pena é reduzida a um meio de comunicação, sem que se possa demonstrar que as mensagens a serem comunicadas dependam necessariamente da pena como meio de transmissão. Naturalmente, existe também um discurso extra-oficial sobre a punição, no qual são apresentadas razões que servem de justificação indireta para a prática penal".

${ }^{56}$ Cf. BARATTA (1994, p. 5); HASSEMER (1991, p. 36).
} 
norma e a fidelidade ao direito por parte dos membros da sociedade" (SANGUINÉ, 1995, p. $83)$.

Por ora, a doutrina segue com a convicção de que o fundamento e os fins da pena são determinações indispensáveis para decidir a forma de atuação do Estado para cumprir a função do Direito Penal. Partindo deste pressuposto, passa-se à análise dos fins das penas nos delitos contra o meio ambiente, que podem ilustrar, de maneira mais contundente, os desafios que hoje se apresentam para o Direito Penal. 


\section{OS FINS DAS PENAS E AS CARACTERÍSTICAS DOS DELITOS CONTRA O MEIO AMBIENTE}

Após analisar os fins tradicionais das penas de maneira geral, pretende-se examinar especificamente quais funções podem cumprir as sanções cominadas aos delitos contra o meio ambiente.

Para examinar as normas de sanção (normas secundárias), faz-se necessário um detalhamento das características gerais da proteção penal dos recursos naturais - previstas nas normas de conduta ${ }^{57}$ (normas primárias) da Lei n. 9.605/98. ${ }^{58}$ A conexão obrigatória do âmbito do "proibido" com o do "punível" revela as decisões político-criminais fundamentais a justificar ou não as condutas sancionáveis. Pretende-se, pois, esboçar de maneira sintética os problemas da tutela penal do meio ambiente que podem ser significativos para o debate sobre as funções da pena. Neste capítulo, sem embargo, não se trata de efetuar uma análise exaustiva de todos os delitos ambientais isoladamente considerados. A pretensão é abordar os elementos do direito criminal ambiental que interferem, direta ou indiretamente, nas finalidades das penas e nos apontamentos teóricos anteriormente referidos.

Convém destacar que, diante das significativas alterações econômicas, culturais e político-sociais do Estado no último século, da intensificação do movimento de globalização e da inflação de normas penais, o Direito Penal expandiu-se a áreas que antes estavam tradicionalmente reservadas ao Direito Civil e Administrativo, passando a tutelar

\footnotetext{
${ }^{57}$ Assim, "sólo la norma (con la conminación penal abstracta) establece pautas de conducta a seguir, con lo que cumple de modo racional su misión de prevención de delitos; a la vez, en ella se plasman buena parte de los criterios garantísticos del Ordenamiento. La norma concreta, en cambio, si se considera desprovista de una conexión con la norma primaria cuya infracción sanciona, no proporciona directriz alguna, con lo que difícilmente se halla en condiciones de prevenir nada. Si la imposición y la ejecución de una pena concreta merecen atención desde la perspectiva de los fines del Derecho penal, como desde luego sucede, ello es fundamentalmente en tanto que confirmación de lo establecido en la conminación abstracta (con independencia de lo cual también es cierto que cumplen otros fines específicos)" (SILVA SÁNCHEZ, 2002, p. 197).

${ }^{58}$ A Lei n. 9.605/98 não incluiu todas as condutas que são punidas por nocivas ao meio ambiente. Como exemplo, cite-se: o crime de difusão de doença ou praga, contido no art. 259 do Código Penal; a proibição da pesca de cetáceos (baleias, golfinhos etc.) nas águas jurisdicionais brasileiras, nos termos do art. $2^{\circ}$ da Lei n. 7.643, de 18 de dezembro de 1987, ou da contravenção prevista na alínea ' $m$ ' do art. 26 da Lei n. 4.771/65 (soltar animais ou não tomar precauções para que o animal de sua propriedade não penetre em florestas sujeitas a regime especial). As análises do presente trabalho restringem-se aos tipos penais descritos na Lei n. 9.605/98.
} 
bens difusos, ${ }^{59}$ além da habitual proteção a bens jurídicos individuais (como a vida ou a liberdade) e sociais (como a fé pública ou as relações de trabalho).

Esta expansão traduz-se por um aumento quantitativo e qualitativo das previsões normativas criminais. No primeiro plano, houve a criação de novos crimes no ordenamento, a tutelar variados comportamentos; em sentido qualitativo, houve reformas para a elevação de sanções referentes a crimes já existentes. ${ }^{60} \mathrm{O}$ remédio penal passou a ser utilizado por órgãos políticos para resolver quase qualquer classe de conflitos presentes na sociedade, o que acarretou transformações profundas na estrutura e nas finalidades das incriminações penais, com alterações das categorias e institutos do Direito Penal tradicional.

Dentre as características do atual Direito Penal expansionista, destaca-se a política de criminalização: o legislador se vê “obrigado a atuar” (HASSEMER e MUÑOZ CONDE, 1995, p. 27), adicionando inclusive a proteção dos direitos supraindividuais entre os bens de relevância jurídico-penal. A inquietação pela proteção do amplo setor difuso da população, composto de vítimas indeterminadas, tem desencadeado o acionamento do resguardo jurídico, gerando assim a responsabilidade civil, administrativa e penal, de modo que as estruturas jurídico-institucionais adaptem-se às novas realidades. ${ }^{61}$

O Direito Penal do meio ambiente, imerso neste panorama, servirá como campo analítico para que se avance na compreensão dos fins das penas. Expõe-se a seguir, pois,

\footnotetext{
${ }^{59}$ Explicita JOSÉ CARLOS BARBOSA MOREIRA os traços básicos dos direitos difusos: "primeiro, a existência de uma pluralidade de titulares, em número indeterminado e, ao menos para fins práticos, indeterminável; segundo, a indivisibilidade do objeto de interesse, cuja satisfação necessariamente aproveita em conjunto a todos, e cuja postergação a todos em conjunto prejudica" (1984, p. 99).

${ }^{60}$ Esse é o diagnóstico de SILVA SÁNCHEZ nas considerações introdutórias de seu livro de Delitos contra o meio ambiente, pois constata que "los tres rasgos característicos de la nueva disciplina legal son el aumento significativo del número de tipos penales y su alcance, el incremento generalizado de las penas imponibles y, en fin, la previsión expresa de la responsabilidad penal de los funcionarios públicos con competencias en materia medio ambiental" (SILVA SÁNCHEZ, 1999, p. 15). SALVADOR NETTO indica o mesmo raciocínio (2009b, p. 19-20): "Esta expansão do Direito penal possui como elemento intrínseco o recrudescimento das penas, notadamente a privativa de liberdade. Esse fenômeno ocorre em dupla medida. De um lado, os novos tipos penais, frutos de opções políticas de criminalização, comumente cominam sanções proporcionalmente mais graves, se cotejadas com os delitos tradicionais. Destarte, cuida-se de uma tendência verificada de maior rigor legislativo, causando, dentro do ordenamento penal como um todo, sério problema de proporcionalidade interna. Por outro lado, delitos já consagrados, por meio de reformas legislativas pontuais, verificam o aumento da gravidade de suas punições".

${ }^{61}$ Além da ação penal, existem vários outros meios processuais de proteção ambiental existem. Fora da área penal, encontra-se a ação popular, a ação civil pública, o procedimento civil ordinário, o mandado de segurança coletivo, a tutela cautelar mediante ação cautelar, a execução específica e o mandamento cominatório (estes últimos nos casos que tenham por objeto o cumprimento de obrigação de fazer ou de não fazer, em que pode haver determinação de cumprimento da prestação da atividade devida ou cessação da atividade nociva, sob pena de execução específica ou de cominação de multa diária).
} 
cada uma das teorias penalógicas, descrevendo-se particularidades da normativa penal meio ambiental que fragilizam sua utilização.

\section{III.1. O bem jurídico ambiental e a prevenção geral integrativa limitadora}

A prevenção geral integrativa limitadora prevê uma afirmação positiva do Direito, com atuação psicológica da norma a fim de garantir a internalização de convicções jurídicas fundamentais por parte da comunidade em geral. Seus parâmetros de intervenção estatal estão, portanto, baseados na proteção dos bens jurídicos essenciais. Esta finalidade da pena não encontra ponto de apoio no bem jurídico ambiental, ${ }^{62}$ porém, porque tal bem apresenta um conceito pouco claro, que prejudica, ainda que teoricamente, a construção das condutas incriminadoras que assegurem a realização da prevenção geral positiva limitadora, o que será tratado neste tópico.

Antes de tratar do bem jurídico propriamente dito, cabem algumas observações sobre a relevância jurídica do tema meio ambiente.

Tendo em vista a degradação que ameaça o bem estar e a qualidade de vida, mostrou-se necessária a proteção jurídica do meio ambiente como forma de assegurar um bem essencial para a sobrevivência digna do ser humano. A tutela jurídica ocorreu com o surgimento de legislação ambiental, cujo escopo fundamental era o combate às formas de perturbação à qualidade do meio ambiente para a preservação do patrimônio ambiental global.

Com o objetivo de tutelar a qualidade de vida, como direito fundamental da pessoa humana, criou-se uma malha legal relacionada a diversos ramos do direito, mas com forte tendência ao direito público, em virtude da contundente presença do poder público no controle do equilíbrio ecológico. Surge, portanto, entre os direitos fundamentais de terceira geração, o Direito Ambiental.

Contudo, o imperativo do crescimento econômico, nas economias capitalistas de mercado, muitas vezes resulta em modelos de desenvolvimento não sustentáveis, em que as atividades econômicas progridem às expensas do meio ambiente. Por esse motivo, a proteção ambiental hoje desponta como preocupação social premente.

${ }^{62}$ Ver PRADO (2005, p. 85-133). 
Diante das vantagens do desenvolvimento das pesquisas científicas e dos avanços tecnológicos para o bem estar social, CORCOY BIDASOLO (2002, p. 615) indica também os efeitos negativos deles consequentes. A temática da destruição ambiental ganha destaque e surge "a imperiosa necessidade de proteger o meio ambiente como interesse coletivo fundamental" (CORCOY BIDASOLO, 2002, p. 616). Assim, floresce a preocupação social e política com o desenvolvimento sustentável, ${ }^{63}$ como norte para que haja uma composição apropriada dos interesses sócio-econômicos com os interesses ambientais.

Nessas bases, o meio ambiente passou a ser interpretado como um bem essencial para o ser humano e inerente a ele. ${ }^{64} \mathrm{O}$ reconhecimento do direito do homem ao ecossistema harmônico e produtivo consagrou o meio ambiente como bem jurídico fundamental à vida humana, com o fim de resguardar o homem de sua própria ação destruidora e ao mesmo tempo garantir o desenvolvimento econômico das nações. ${ }^{65}$

O "moderno dirigismo intervencionista do Estado" sobre os "bens jurídicos monopolizados" (SGUBBI, 1998, p. 99) traz mudanças de paradigmas, caracterizados principalmente pela diferença entre os destinatários das normas penais e pela distinção existente nas respostas penais aplicadas em cada caso. Tal dirigismo admite a importância do desenvolvimento industrial e tecnológico para a satisfação das necessidades da

\footnotetext{
${ }^{63} \mathrm{Na}$ Conferência das Nações Unidas para o Meio Ambiente e o Desenvolvimento, em 1992, no Rio de Janeiro, surgiu a "Declaração do Rio de Janeiro", com 27 princípios, entre eles o do desenvolvimento sustentável, visando à racionalização do uso dos recursos naturais para atender às necessidades presentes, sem comprometer as das gerações futuras. A sustentabilidade idealiza uma corrente harmônica entre o processo econômico e o processo de preservação ambiental e busca a convergência dos interesses individuais e metaindividuais imbricados entre si, com o escopo de compatibilizar o desenvolvimento sócio-econômico com o equilíbrio ecológico. Ciente de que o movimento econômico, por si só, não se sustenta, e que toda ação humana é, de alguma forma, predatória e autodestruidora, procura-se um modelo de desenvolvimento, que evidentemente será composto de indústrias transformadoras do meio, mas que demonstre ser sustentável para que toda mudança na ordem natural não acarrete alterações de caráter inesperado e irreversível, comprometendo a saúde do subsistema econômico, fortemente dependente do equilíbrio do sistema ambiental.

${ }^{64}$ No cenário internacional, a Declaração de Estocolmo sobre o Meio Ambiente Humano dispõe: PRINCÍPIO 1. $\mathrm{O}$ homem tem o direito fundamental à liberdade, à igualdade e ao desfrute de condições de vida adequadas em um meio ambiente de qualidade tal que lhe permita levar uma vida digna e gozar de bem-estar, tendo a solene obrigação de proteger e melhorar o meio ambiente para as gerações presentes e futuras. A este respeito, as políticas que promovem ou perpetuam o apartheid, a segregação racial, a discriminação, a opressão colonial e outras formas de opressão e de dominação estrangeira são condenadas e devem ser eliminadas. PRINCÍPIO 2. Os recursos naturais da terra incluídos o ar, a água, a terra, a flora e a fauna e especialmente amostras representativas dos ecossistemas naturais devem ser preservados em benefício das gerações presentes e futuras, mediante uma cuidadosa planificação ou ordenamento. PRINCÍPIO 3. Deve-se manter, e sempre que possível, restaurar ou melhorar a capacidade da terra em produzir recursos vitais renováveis. Sobre a expansão dos Direitos Humanos até abranger a proteção do meio ambiente, ver COMPARATO (2001).

${ }^{65} \mathrm{O}$ direito econômico buscou a regulamentação da atividade econômica que se apropriava de recursos naturais a custo zero. As teorias de COASE e PIGOU, por exemplo, visaram a enfrentar o chamado "problem of the social cost", seja com a extensão dos mercados sobre danos ambientais, seja com a internalização desses custos sociais por determinados agentes econômicos (DERANI, 1997, p. 108-109).
} 
sociedade atual, mas reconhece sua interferência no equilíbrio ecológico. Portanto, o tema da preservação ambiental e da exploração sustentável dos recursos naturais passou a integrar a esfera de ação da política criminal.

Os defensores da conservação e proteção dos recursos naturais por meio da intervenção penal utilizam como primeiro argumento de legitimidade (CORCOY BIDASOLO, 2002, p. 624) a previsão do mandato constitucional expresso de criminalização, ${ }^{66}$ no Brasil encontrado no capítulo "Da ordem Social”, no caput do artigo 225 da Constituição Federal: ${ }^{67}$

Todos têm direito ao meio ambiente ecologicamente equilibrado, bem de uso comum do povo e essencial à sadia qualidade de vida, impondo-se ao Poder Público e à coletividade o dever de defendê-lo e preservá-lo para as presentes e futuras gerações. ${ }^{68}$

O parágrafo $3^{\circ}$ deste mesmo artigo contém referência expressa aos tipos de sanções, administrativa ou penal, passíveis de serem aplicadas no caso de atividades consideradas lesivas ao meio ambiente, independente da obrigação de reparar os danos causados.

$\mathrm{O}$ art. 170 da Constituição Federal trata também, abertamente, do tema da proteção ambiental, como reflexo e extensão do inviolável direito fundamental à vida sadia e com qualidade, ao desenvolvimento econômico, em dois pólos: a livre concorrência e a defesa do meio ambiente.

Da previsão constitucional parte-se, neste trabalho, de alguns posicionamentos importantes. O primeiro trata da prevalência da postura subsidiária do Direito Penal, ${ }^{69}$ para

${ }^{66}$ Ver PRADO (2005, p. 63-84).

${ }^{67}$ Outros dispositivos mencionam direta ou indiretamente o meio ambiente: art. $5^{\circ}$, incisos XXIII, LXXI, LXXIII; art. 20, I a XI, e $\S \S 1^{\circ}$ e $2^{\text {o }}$; art. 21, XIX, XX, XXIII, $a, b$ e $c$, XXV; art. 22, IV, XII, XXVI; art. 23, art. 26, I a IV; art. 30, I, II, VIII; art. 43, $\S 2^{\circ}$, IV e $\S 3^{\circ}$; art. 49, XIV e XVI; art. 91; art. 129, III; art. 170; art. $174, \S \S 3^{\circ}$ e $4^{\circ}$; art. 176 e parágrafos; art. 182 e parágrafos; art. 186 ; art. 200 , VII, VIII; art. 216, V e $\S \S 1^{\circ}, 3^{\circ}$ e $4^{\text {o }}$; art. 225; art. 231; art. 232; ADCT: art, 41 e art, 44 e parágrafos.

No âmbito federal, deparamo-nos com a Lei de Política Nacional do Meio Ambiente, que o conceitua como "o conjunto de condições, leis e influências e interações de ordem física, química e biológica, que permite, abriga e rege a vida em todas as suas formas" (art. $3^{\circ}$, inciso I)

${ }^{68}$ Sobre a redação constitucional, $S A$ pondera: "queremos chamar a atenção para o grau de abstração do conceito e para o grau de refinamento de julgamento que são exigidos para se entender o bem tutelado e o caráter de ilicitude da conduta que lesa esse bem. Trata-se de um bem, que é o meio ambiente (o que é o meio ambiente?), de uso comum (portanto não pertence a ninguém particularmente), essencial à sadia qualidade de vida (o que é qualidade de vida?) e que deve ser defendido e preservado para as gerações (isto é, não se trata de beneficiar alguém particularmente), e não só as gerações presentes, mas também para as futuras, ou seja, para pessoas que ainda não existem. Parece-nos evidente ser exigido aqui um grau sofisticado de elaboração para compreender o texto." (2008, p. 199).

${ }^{69}$ A proteção penal distingue-se das demais porque a intervenção estatal só será justificável quando houver, segundo entendimento de ANTONIO GARCÍA-PABLOS DE MOLINA (1995, p. 265), a salvaguarda de interesses ou condições que "reúnam duas características: em primeiro lugar, a da generalidade (deve tratar-se de bens ou condições que interessam à maioria da sociedade e não a uma parte ou setor desta); em segundo lugar, a da transcendência (intervenção penal somente se justifica para tutelar bens essenciais para o homem e a 
que a intervenção punitiva do Estado, com a imposição de pena, ocorra apenas como ultima ratio, "quando resultem insuficientes outras vias sancionadoras extrapenais, menos gravosas"; em suma, caberia a imposição da sanção penal somente "para aqueles ataques mais intoleráveis contra o meio ambiente" (BARREIRO, 2005, p. 7).

O segundo posicionamento versa sobre o fato de o bem jurídico ambiental continuar questionado como bem de relevância jurídico-penal, ${ }^{70}$ seja da perspectiva antropocêntrica, seja da ecocêntrica, ${ }^{71}$ por ter contornos difusos, o que dificulta enormemente sua determinação (SILVA SÁNCHEZ, 1999, p. 19).

Parte desta dificuldade foi descrita por SOTO NAVARRO, em seu capítulo sobre a “materialidade e caráter lesionável dos bens jurídicos coletivos” (SOTO NAVARRO, 2003, p. 277-316), no qual estabelece a diferença de lesão entre os bens individuais e os supraindividuais, indicando que existe uma falta de parâmetros sobre os quais se pode delimitar unidades lesionáveis dos bens jurídicos supraindividuais, já que eles não podem se resumir à mera soma de interesses individuais. ${ }^{72}$ A autora constata uma "ruptura entre o resultado material, como elemento estrutural do tipo, e a lesão do bem jurídico, como elemento fundamentador do injusto (desvalor de resultado), de tal modo que não parece possível sua presença conjunta em uma mesma figura delitiva" (SOTO NAVARRO, 2003, p. 280). Afirma-se, pois, que a conduta típica, geradora de um resultado, não acarreta obrigatoriamente a afetação do bem jurídico supraindividual protegido, constatação que depende de comprovação de sua idoneidade para afetá-lo ${ }^{73}$ (CORCOY BIDASOLO, 1999, p. 165-170).

Neste sentido, SILVA SÁNCHEZ aponta que "o bem jurídico do meio ambiente (ou o ‘equilíbrio dos sistemas naturais', como previsto no art. 325 [do Código Penal espanhol]) é um dos menos precisos" (1999, p. 17), ${ }^{74}$ o que dificulta a interpretação dos tipos. A

sociedade, vitais). O contrário é um uso sectário ou frívolo do direito penal: sua perversão. O Direito Penal exerce, assim, um controle social residual - que atuará somente no insucesso de outras formas de controle -, ao tentar impedir as práticas que ferem os mais elevados e relevantes interesses da sociedade".

${ }^{70}$ Segundo MACHADO, há uma desmaterialização do bem jurídico, com o distanciamento da objetividade natural, centrada em lesões individuais, para uma intervenção penal na proteção de bens jurídicos universais ou coletivos, de características vagas e abstratas (2005, p. 107).

${ }_{71}^{71}$ Largo debate sobre esse tema puede ser encontrado en BARREIRO (2005, p. 28-46).

72 Essa distinção também foi apresentada por JOSÉ AFONSO DA SILVA (2002, p. 81) ao apresentar dois objetos de tutela ambiental (objetos imediato e mediato), sendo que o mediato constitui a qualidade do meio ambiente e o imediato, a qualidade de vida (saúde, bem-estar e segurança da população).

${ }^{73} \mathrm{O}$ tema é tratado neste trabalho no item sobre os crimes de perigo abstrato (item III.4).

${ }^{74}$ No Direito espanhol, particularmente sobre o bem jurídico ambiental, SILVA SÁNCHEZ ilustra sobre o artigo 325, I, do Código Penal espanhol, que "esta cuestión resulta especialmente trascendente si advertimos que el 
questão se mostra grave dado que a precisão do bem jurídico penal constitui traço essencial para a verificação do injusto, diante da necessária análise do risco jurídico penal relevante apto a definir o comportamento típico (jurídico-penalmente desaprovado).

Surge, portanto, uma fragilidade no sistema penal, porque o bem jurídico ambiental, de pouca clareza, prejudica a estabilidade na interpretação dos tipos penais (SILVA SÁNCHEZ, 1999, p. 17). Se existe dificuldade para a plena compreensão do bem jurídico, ${ }^{75}$ a limitação e a legitimidade de atuação do poder punitivo estatal são postos em xeque. Dessas incertezas nos contornos e, como resultado, na interpretação dos tipos penais ambientais, decorre uma crítica à função preventivo-geral integrativa, que, em sua versão limitadora, baseia os parâmetros de intervenção na medida de proteção dos bens jurídicos essenciais.

Observa-se, em outras palavras, uma incerteza sobre a capacidade de a norma constituir-se como núcleo de convicções axiológicas partilhadas para a formação do centro de valores internos da sociedade - missão preventiva -, quando não se verifica um bem jurídico certo. Assim, HASSEMER afirma que "quanto mais vago é o conceito de bem jurídico e quantos mais objetos abarca, mais tênue se torna a possibilidade de contestar a nossa pergunta de se o Direito Penal cumpre sua função preventiva” (HASSEMER, 1991, p. 32). De fato, somente se podem esperar comportamentos obedientes ao Direito e um reforço do ordenamento se há clareza com relação a quais bens jurídicos verdadeiramente se protege.

Frente à dificuldade de observar lesão ao bem jurídico ambiental, questiona-se se o Direito Penal haveria de ser utilizado como forma de controle social. MIR PUIG adverte sobre o risco existente na utilização do Direito Penal como simples instrumento sancionador, de apoio a normas não penais, com a ilusão de uma maior eficácia. O autor postula a autonomia do Direito Penal na incriminação de condutas, de modo que somente

tipo básico tiene una redacción claramente 'normativista', de modo que resulta imposible llegar a conclusión alguna sobre su alcance de la mano de sus elementos descriptivos." (SILVA SÁNCHEZ, 1999, p. 17).

75 HASSEMER compartilha esse entendimento: "Ya en una primera aproximación vemos que las nuevas leyes en el ámbito de nuestro Derecho penal material (Parte Especial y leyes penales especiales) no tienen como objeto de protección sólo bienes jurídicos universales sino asimismo que estos bienes jurídicos universales están formulados de forma especialmente vaga. Ámbitos específicos de promulgación de leyes son fundamentalmente el Derecho penal económico, los impuestos, medio ambiente, acumulación de datos, terrorismo, drogas, exportación de materias peligrosas. Los bienes jurídicos comprendidos en este ámbito son tan generales que no dejan ningún deseo sin satisfacer. Se trata de una criminalización anticipada a la lesión del bien jurídico; de la protección del 'bienestar' de los hombres 'en un sentido puramente somático' en vez de la protección de la vida y la salud de las personas; de la salud publica; del funcionamiento del mercado; de la protección estatal empresarial o de la acumulación de datos comercial o administrativa" (HASSEMER, 1991, p. 32-33). 
aos ataques sentidos pela coletividade como contrários a interesses fundamentais para a vida social se comine pena. Nesse sentido, afirma que "não é correto acudir à intervenção penal com o fito de conseguir um efeito dissuasório mais intenso a respeito de infrações de normas não suficientemente internalizadas pela consciência social" (MIR PUIG, 1994, p. 156). A cominação penal em tais casos, contrariamente ao pretendido, não provocaria, ao seu juízo, um maior grau de eficácia, porquanto não corresponde à convicção social; ao contrário, deterioraria a função de prevenção geral positiva de Direito Penal.

\section{III.2. Os destinatários das normas penais ambientais e a prevenção especial positiva}

A função de evitar novos delitos por aqueles que já demonstraram seu desprezo pelo ordenamento jurídico é o intuito da prevenção especial positiva. Com a crença de ressocializar o infrator, a medida preventiva especial em matéria de meio ambiente não obtém êxito se for considerado que ela incide justamente sobre os sujeitos mais adaptados à racionalidade social. ${ }^{76}$

Inegavelmente, a lógica capitalista conduz a atividades econômicas de produção, que, por sua vez, acarretam necessariamente graves ofensas ao meio ambiente. Desta feita, para a manutenção da sociedade atual, não se pode crer na proteção absoluta dos recursos naturais (MÜLLER-TUCKFELD, 2000, p. 522).

Contudo, o expansionismo penal resultou na incriminação de condutas contra o meio ambiente que põe em foco os indivíduos que detêm os meios de produção, ou seja, aqueles com maior poder na sociedade industrial de massas. Segundo SGUBBI (1998), o Direito Penal, com a premissa do delito como risco social, ${ }^{77}$ ampliou os setores da sociedade ao qual dirige sua atuação, aplicando o controle penal e a repressão não somente

\footnotetext{
${ }^{76}$ Merece destaque o posicionamento de VICENTE MARTÍNEZ (2008, p. 191): "es precisamente la idea de que el delincuente económico no necesita d resocialización la que ha llevado a un sector de la doctrina a considerar inidónea a la pena privativa de libertad. Se ha afirmado que el delincuente económico o de cuello blanco es el paradigma de sujeto que no requiere de resocialización y menos de resocialización carcelaria".

${ }^{77}$ Pondera SGUBBI que "el delito se ha transformado en un riesgo social. Un riesgo: porque la configuración de la responsabilidad penal ya no puede ser prevista más de manera absoluta y a priori, sino que se presenta como un dato incierto, cuando no de mera suerte; y porque ella depende, cada vez con mayor frecuencia, de factores diversos de la comisión culpable de una conducta lesiva. Aunque conservando las tradicionales semblanzas formales de una libre elección subjetiva, el delito se encamina progresivamente a fundarse sobre factores que son (en gran parte) independientes del individuo, esto es, no está en condiciones de dominar o del controlar" (SGUBBI, 1998, p. 49).
} 
aos indivíduos mais frágeis (atores usuais dos crimes patrimoniais convencionais), mas também aos sujeitos considerados economicamente produtivos, ${ }^{78}$ cujas atividades, apesar de sua importância para o desenvolvimento econômico, geram um relevante risco penal, em razão da necessária submissão ao cumprimento a uma série interminável de deveres administrativos sancionados sob a ameaça penal. ${ }^{79}$

Desse modo, a responsabilidade penal, direcionada a amplos setores da vida econômica e social, não mais apresenta diretamente uma reprovação ao sujeito pelas eleições de condutas reprováveis que tenha escolhido e executado. Pelo contrário, como aponta $S G U B B I$, baseia-se no "simples fato do desenvolvimento de uma atividade lícita 'neutra' do agente: tal atividade gera por si só, objetivamente uma responsabilidade penal do sujeito pela inobservância, pela mera transgressão - ainda que seja casual, acidental das prescrições normativas ditadas pela disciplina administrativa da mesma atividade, em vista de um bom-fim a se perseguir" (SGUBBI, 1998, p. 97).

Neste contexto de moderno Direito Penal “omnicompreensivo” (SGUBBI, 1998, p. 56), que perdeu seu caráter fragmentário, os sujeitos pertencentes aos estratos financeiramente privilegiados da sociedade - antes distanciados deste tipo de controle agora estão expostos a maior risco penal, em que pese sua posição econômica e social e o tipo de atividade, geralmente lícita, que desenvolvem.

O fim de prevenção especial positiva, frente às constatações acima mencionadas, torna-se prejudicado, porque não existe um desvio na personalidade do autor, carente de uma ressocialização ou internalização de novos valores, ${ }^{80}$ seja porque uma amplitude das condutas puníveis neste âmbito deriva de fatos culposos, o que não justifica a alteração de caráter do autor (ROXIN, 1997, p. 87), seja porque o Estado, em certa medida, estimula tais atividades, capazes de fomentar o crescimento econômico.

Tais fragilidades manifestam-se também no âmbito individual. Mesmo que se considere possível o cálculo racional de custos e benefícios, os agentes do sistema

\footnotetext{
${ }^{78}$ Sob o enfoque clínico-criminológico, ALVINO AUGUSTO DE SÁ faz análise sobre os crimes ambientais, aduzindo que "os autores dos crimes ambientais, assim como os de colarinho branco, costumam ser 'pessoas de bem', bem posicionadas socialmente, bem-sucedidas, que não usam de violência, tratando-se, não raramente, de empresários que prestam 'serviço de inestimável valor social', seja pela oferta de seus produtos, seja pela 'gentil' oferta de empregos" (2008, p. 198).

${ }_{79}$ Ver DIAS, a respeito de condutas consideradas neutras do ponto de vista axiológico (2006, p. 65).

${ }^{80}$ Não compartilha deste pensamento DIAS, para quem "o crime económico releva, em princípio, um defeito de socialização - que não tem que ver com o Weltanschaung do delinquente, com a estabilização da sua inserção (cultural, económica, familiar) na comunidade, mas concretamente com sua atitude pessoal perante uma especial Orientação estadual em matéria sócio-econômica.” (2006, p. 67).
} 
econômico tendem a optar pelas condutas produtivas, porque as concebem como socialmente adequadas. A percepção do injusto nos delitos ambientais se manifesta menos palpável, porque a conduta considerada lesiva no ordenamento não constitui um ato facilmente compreendido pela sociedade como lesivo. Atividades tecnicamente refinadas, que não afligem um sujeito determinado, tampouco são imediatamente perceptíveis por terceiros não especializados, parecem socialmente permitidas. Por essa razão, as hipóteses de dirigismo de comportamento preventivo especial se mostram extremamente debilitadas na esfera penal ambiental.

Igualmente, segundo a crítica de ROXIN exposta no capítulo anterior, ${ }^{81}$ não se compreende aplicável o fim preventivo especial positivo para hipóteses extremas de degradação ambiental, que impossibilitam uma reiteração de conduta. Tais casos, de injustos irrepetíveis, não são passíveis de reincidência - a prevenção especial não pode, portanto, alcançar seu objetivo, isto é, a inocorrência de novos delitos pelo mesmo autorinfrator.

\section{III.3. A acessoriedade na legislação penal ambiental e a prevenção geral integrativa fundamentadora}

A técnica legislativa de elaboração de descrições típicas dos delitos contra o meio ambiente se apoiou na complementação de conceitos, normas ou atos administrativos para a configuração do injusto ambiental. ${ }^{82}$ Essa apropriação de elementos normativos do direito administrativo para a criação de delitos ambientais acarretou profunda complexidade das normas penais ambientais. Como resultado, os cidadãos se deparam com dificuldades de entendimento para agir com fidelidade às normas em questão, como pretendido pela função preventivo-geral integrativa fundamentadora.

O termo acessoriedade ${ }^{83}$ não decorre de uma concepção de intervenção mínima, na qual se busca o acionamento do Direito Penal apenas de forma acessória e secundária, quando o Direito Administrativo não seja suficiente para a resolução do conflito. Em realidade, o uso deste conceito justifica-se porque o Direito Penal utiliza o Direito

\footnotetext{
${ }^{81}$ Item III.4.B.b.1.

${ }^{82}$ Cf. PRADO (2005, p. 98-101).

${ }^{83}$ Embora parte da doutrina faça uso da grafia "assessoriedade", mantém-se a grafia "acessoriedade" neste trabalho, pelas razões acima expostas. Em sentido contrário, ver COSTA (2010).
} 
Administrativo como acessório e complemento para a compreensão do injusto ambiental, que normalmente estabelece condutas proibidas com base em diversos conhecimentos técnicos e científicos.

A interrelação entre o Direito Penal e o Direito Administrativo suscita questões relevantes no que tange à função da pena, como a constitucionalidade e os limites das leis penais em branco, e a difícil fixação dos limites do injusto e do risco permitido.

As leis penais em branco são entendidas como normas penais incompletas, que não contêm uma descrição fechada do fato proibido e requerem a integração com outras instâncias normativas, de natureza legal ou regulamentar (MIR PUIG, 2007, p. 75-77). De forma sucinta, constata-se que a utilização da técnica das leis penais em branco foi, em certa medida, aceita pela doutrina ${ }^{84}$ ao considerar que se mantém no âmago da norma criminal a delimitação do núcleo essencial do injusto (MIR PUIG, 2007, p. 75-77), a ser complementado pelo âmbito administrativo.

A discussão que se levanta a respeito do princípio da legalidade versa sobre a remissão a normas de nível inferior à lei. De fato, a remissão a normas emanadas por autoridades administrativas, para a integração do fato típico, pode vulnerar o princípio da reserva de lei como garantia criminal do princípio da legalidade, e em consequência colidir com o fundamento político-constitucional deste postulado, sustentado na divisão de poderes e no paradigma democrático. Nesta situação, o poder executivo, em última análise, é quem seleciona as condutas penalmente relevantes.

Inegável reconhecer que este método dificulta o conhecimento da matéria de proibição, frente à remissão a uma normativa administrativa que nem sempre é clara, completa ou sistematizada, dada a inexistência de uma lei geral e unificada sobre as questões referentes ao meio ambiente ${ }^{85}$ (BARREIRO, 2005, p. 53).

\footnotetext{
${ }^{84}$ Neste sentido, CORCOY BIDASOLO, reconhecendo as dificuldades das normas penais em branco, afirma que "es la única técnica posible, por cuanto, debido a las modificaciones continuas derivadas de los avances tecnológicos, a la aparición de nuevos problemas y, por supuesto, de la concepción de la protección del medio ambiente bajo el concepto de 'desarrollo sostenible' no existe un criterio univoco sobre lo que se tolera o no en un determinado momento sino que esta decisión es una decisión política en la que se deben tomar en consideración múltiples factores" (CORCOY BIDASOLO, 2002, p. 622).

${ }^{85}$ Em nosso ordenamento, apesar de existir o Decreto n. 6.514, de 22 de julho de 2008, que versa sobre as infrações e sanções administrativas ao meio ambiente, ainda há uma ampla gama de normas esparsas sobre a temática do meio ambiente, como leis federais, estaduais, municipais, portarias do IBAMA e resoluções complementares.
} 
Ademais, outra dificuldade está relacionada com a competência concorrente, ${ }^{86} \mathrm{o}$ que acarreta disparidade de regulamentações entre diferentes municípios e estados, podendo uma conduta ser típica em um local e atípica em outro. Como resultado, em muitos casos se constata infração ao princípio da igualdade, além de virtual impossibilidade de conhecimento das leis.

Os problemas não se resumem somente a estes, que fragilizam o princípio da legalidade. Existem situações que colocam em risco a segurança jurídica, uma vez que infrações puramente administrativas ${ }^{87}$ podem gerar efeitos profundos no âmbito penal.

Partindo da classificação das formas de acessoriedade entre o Direito Penal e o Direito Administrativo em matéria ambiental, aludida por MATA BARRANCO (1996, p. 77), de acessoriedade conceitual, acessoriedade normativa e acessoriedade de ato ou formal, ${ }^{88}$ duas questões ainda merecem destaque.

Quanto à acessoriedade normativa - já tratada pelas menções sobre a lei penal em branco -, subsiste uma importante discussão a respeito da irretroatividade das disposições restritivas de direitos e de retroatividade de disposições favoráveis nos casos de modificação de diretrizes administrativas (normas de complemento) para a configuração de atipicidade de comportamentos ilícitos finalizados, ${ }^{89}$ que ainda não encontra uma resposta pacífica (SILVA SÁNCHEZ, 1999, p. 59).

Também se alerta, sem a pretensão de apresentar soluções, para a problemática da acessoriedade de ato, relativa à exigência de requisitos de validade ou de mera eficácia do ato administrativo, para outorgar relevância a efeitos de exclusão de responsabilidade penal. Ainda subsistem dúvidas sobre os efeitos da autorização administrativa: a

${ }^{86}$ Ver ANTUNES (2007).

87 Já destacou REALE JÚNIOR (2009, p. 25) que "grande parte dos delitos é de mera desobediência, pois se recorre à lei penal para impor comportamentos de respeito a regulamentos, como se dá, por exemplo, no art. 56, que incrimina a ação de "usar substâncias tóxicas em desacordo com as exigências estabelecidas na lei ou nos seus regulamentos', cominando-se grave pena de um a quatro anos de reclusão para tal infração.”

${ }^{88}$ Distingue-se: a. Acessoriedade conceitual, que é a classe de acessoriedade em que a norma penal se relaciona com conceitos administrativos mediante elementos normativos, que encontram seu sentido na regulamentação extrapenal; b. Acessoriedade de direito ou normativa: neste modelo, o tipo se configura como uma lei penal em branco e é remetido, de modo explícito ou implícito, à violação da norma administrativa; c. Acessoriedade de ato formal:a relevância penal do fato se faz depender completamente da violação da atuação administrativa concreto, ou da existência de autorização do comportamento, o qual pode operar como elemento típico ou como elemento integrante de exclusão de antijuridicidade. Ver MATA BARRANCO (1996).

${ }^{89}$ O Supremo Tribunal Federal assim se manifestou, nos anos 1950: “a mudança ou alteração dos respectivos complementos administrativos não determina a aplicação do princípio da retroatividade in melius." (STF, HC n. 32460, Rel. Min. Rocha Lagoa, $6^{a}$ T., julgamento em 20/05/1953). Contudo, a questão não é pacífica na doutrina, como apontam DELMANTO ET ALLI (2010, p. 90-91). Sobre os problemas da acessoriedade administrativa ver GRECO (2006). 
atipicidade por autorização posterior, a verificação de autorização inválida ou as situações em que todas as exigências da autorização estavam preenchidas, mas não houve o trâmite formal de solicitação. ${ }^{90}$

Torna-se questionável condicionar a relevância penal do comportamento à mera licitude formal da autorização, sem averiguar a relevância material da conduta, uma vez que pode gerar hipóteses de condutas gravemente atentatórias ao meio ambiente, mas convalidadas por uma autorização administrativa; ou de condutas pouco lesivas, que cumprem todos os requisitos da legislação ambiental, mas que são punidas no âmbito administrativo por falta de procedimento formal de obtenção do documento de autorização. ${ }^{91}$

Outro ponto especialmente discutido é o da indagação a respeito da validade da autorização. Sobre esse aspecto, apesar da existência de licitude formal, o instrumento depende de verificação da licitude material do ato, seja por questões de corrupção, seja por falta de atualização e renovação da autorização, ${ }^{92}$ ou por interpretação da extensão do ato administrativo. $^{93}$

Com o modelo de acessoriedade de ato incrementam-se as anomalias em matéria de conhecimento da antijuridicidade, já que o sujeito que vê sua atividade amparada por uma autorização administrativa, ainda que ilícita, pode desconhecer ou mal-interpretar o sentido de seu comportamento. Essa comprovação provisória da licitude da autorização pode gerar

\footnotetext{
${ }^{90} \mathrm{Na}$ esfera do Direito Penal Financeiro, MACHADO destaca a importância da autorização administrativa e sua relação com o Direito Penal nos crimes de gestão fraudulenta, apropriação indébita financeira, concessão de empréstimo vedados e evasão de divisas: “a existência ou não de 'autorização possui duas características importantes. Trata-se de uma informação que apenas pode ser prestada pela autoridade administrativa e, ao mesmo tempo, constitui um elemento indispensável à configuração dos crimes mencionados. É possível dizer, portanto, que o ponto de contato entre a esfera penal e a administrativa é, nesses casos, a exigência de autorização administrativa. A conduta em si não configura infração, pois a violação da norma penal ocorre apenas se não havia autorização da esfera administrativa" (2009:95, grifos do original).

${ }^{91}$ Sobre essa matéria, EDUARDO REALE FERRARI e HELENA REGINA LOBO DA COSTA argumentam que "deve-se fazer uma leitura harmônica dos dispositivos e não se deve punir criminalmente o administrado que agia em conformidade com a licença regularmente obtida - mesmo que esse ato administrativo contrarie normas legais ou regulamentares. Isto porque o ato administrativo goza de presunção de legalidade e o administrado age acreditando na validade do ato administrativo. Também aquele que age sem licença, mas cuja atividade desenvolvia-se de acordo com os preceitos legais, deve restar alheio à punição criminal.” (2009, p. 267).

92 TIEDEMANN por exemplifo afirma que "numerosas autorizaciones, en especial las relacionadas con vertidos de desechos en las aguas, fueron otorgadas hace tiempo y se refieren a las sustancias con capacidad de dañar que hoy ya no podría ser autorizada" (TIEDEMANN, 1985, p. 146).

${ }_{93}$ Com base no Tribunal Constitucional da Alemanha, TIEDEMANN afirma que "hay abuso de derecho cuando la acción autorizada conduce a lesiones corporales de terceros. La autorización, en suma, tendrá validez exclusivamente respecto de los correspondientes tipos penales sobre el medio ambiente, pero no en general frente a todas las disposiciones del Derecho Penal" (TIEDEMANN, 1985, p. 146).
} 
uma situação de insegurança jurídica, que admite interpretação de exclusão da ilicitude penal ou erro de proibição invencível ou vencível.

Os problemas indicados sobre o mandato de taxatividade imposto às normas penais desguarnecem qualquer intento de função preventivo-integradora fundamentadora de reafirmação do ordenamento.

Se as disposições são notavelmente incompletas ou de difícil conhecimento, não se pode exigir da sociedade a internalização dos preceitos indeterminados que elas apresentam. Em outros termos, se a norma é incompreensível e ambígua, não se obtém o êxito de motivar seu destinatário a fortalecer a confiança geral na validade e vigência do ordenamento jurídico.

Mesmo se a proposição de prevenção geral por meio da comunicação fosse vista como apta a consolidar a fidelidade ao Direito, não se pode esperar que o cidadão seja fiel a um ordenamento jurídico que deixa de outorgar ordens claras e precisas - configurando uma comunicação deficiente. $\mathrm{O}$ estremecimento da vigência da norma não está na conduta ilícita do autor que nega a validade do ordenamento, mas, em realidade, está ínsito ao próprio sistema jurídico de preceitos vagos.

\section{III.4. Delitos de perigo abstrato e a função retributiva}

Se, por um lado, a função retributiva foi repudiada na sua versão radical, ela foi aplaudida em relação aos pressupostos de limitação do poder punitivo, com o estabelecimento de punição nos limites da culpabilidade, de forma a assegurar o princípio da proporcionalidade. Contudo, qualquer forma de pretender estabelecer uma igualdade, ainda que normativa, entre o mal cometido pelo infrator e a resposta estatal suficiente, constitui tarefa de difícil apuração, ${ }^{94}$ ainda mais quando se trata de delitos de perigo abstrato.

A normativa penal do meio ambiente, com o objetivo de se afastar das travas existentes na legislação tradicional, ${ }^{95}$ optou por utilizar os delitos de perigo abstrato para a

\footnotetext{
${ }^{94}$ Conforme exposto no item II.4.A, sobre a função retributiva.

${ }^{95}$ SILVA SÁNCHEZ esclarece as dificuldades de viabilizar o delito do artigo 347 bis do derrogado Código Penal espanhol: "en primer lugar, porque obligaba a constatar relaciones de causalidad entre la conducta de realizar emisiones o vertidos y el referido resultado en un contexto en el que ello resulta altamente complejo, tanto
} 
proteção do equilíbrio ecológico. Nesse sentido, não se necessita mais do nexo de causalidade entre a conduta e o resultado de perigo concreto: o Direito Penal ambiental satisfaz-se com uma ação apta a produzir um perigo ao bem jurídico. ${ }^{96}$ Nesse esteio, basta a criação de uma situação provável para que o resultado lesivo se produza e a sanção penal seja acionada. ${ }^{97}$

Repudia-se o entendimento - embora tenha sido a lógica do legislador - de que o crime de perigo abstrato seria equivalente ao crime cujo perigo é presumido, ${ }^{98}$ no qual a simples constatação da conduta proibida descrita no tipo pressupõe o perigo pela mera ratio legis, ${ }^{99}$ excluindo a necessária constatação do perigo no caso concreto. Essa é a racionalidade do Direito Administrativo, que, com fundamento em estatísticas ou em regras de experiência, limita o âmbito de atuação do indivíduo ou da empresa, com o fim de evitar situações presumidamente perigosas. Um exemplo desta atuação é o estabelecimento de limites máximos de velocidade em determinadas vias, sendo que a mera desobediência desta margem cria o ilícito. O risco neste caso é presumido, não importando que o agente seja o mais habilidoso dos condutores ou que tenha pleno controle do veículo. Consequentemente, consuma-se o delito pela realização da conduta supostamente perigosa; não cabe ao julgador valorar se esta conduta poderia ou não ocasionar dano. $^{100}$

por la aparición de situaciones de desconocimiento de elementos de hecho o de leyes científicas, como por dificultades probatorias. En segundo lugar, porque no cabe ignorar que en este ámbito lo más frecuente será la aparición de fenómenos de causalidad cumulativa. Asimismo, en tercer lugar, porque será relativamente frecuente que el resultado de peligro se produzca tras un elevado lapso de tiempo. Ello genera relevantes dificultades tanto para el establecimiento de una relación de causalidad entre conducta y resultado de peligro, como para su valoración jurídico-penal, con la correspondiente imputación" (1997, p. 1716).

${ }^{96}$ Cf. SILVEIRA (2003), que discorre sobre a construção típica do crime de perigo e seu elemento subjetivo no âmbito dos interesses supra-individuais.

97 PAULO JOSÉ DA COSTA JÚNIOR constata que, em realidade, os crimes ambientais "não se concentram na lesão de um bem jurídico, mas são crimes de 'desobediência', onde o elemento normativo - inobservância das disposições da autoridade - assume tamanha amplitude que exaure toda a conduta constitutiva do delito [...] apresenta-se o crime ecológico, nesses casos, como tipos de mera violação de um dever formal de obediência a normas extrapenais que governam a matéria." (1996, p. 83).

${ }^{98}$ MACHADO esclarece o conceito de teoria da causalidade epidemiológica, utilizada com o fim de abandonar as exigências de nexo de causalidade: "por intermédio da incidência estatística do resultado em função da imaginada causa, melhor dizendo, com base em uma hipótese experimental e não em uma lei causal reconhecida pela ciência, presume-se o nexo de causalidade e se aceita a imputação de responsabilidade com base nessa presunção" (2005, p. 125).

99 Cf. PRADO (2005, p. 135-143) que define o crime de perigo abstrato como aquele em que "o perigo constitui unicamente a ratio legis, isto é, o motivo que inspirou o legislador a criar a figura delitiva. Mas, aqui, o perigo não aparece como elemento do tipo objetivo, e o delito se consuma mesmo que no caso concreto não se tenha verificado qualquer perigo para o bem jurídico tutelado, bastando a simples comprobação de uma atividade finalística perigosa." (2005, p. 137).

${ }^{100}$ Sob uma perspectiva crítica: FIGUEIREDO (2008, p. 233-248). 
HASSEMER afirma que, à diferença dos delitos de resultado, os de perigo abstrato não dependem da comprovação da verificação de um prejuízo e do vínculo entre comportamento criminalizado e a lesão do bem jurídico. Os crimes de perigo abstrato, de fato, configuram uma atividade criminalizada pelo legislador; por isso, "se na eleição desta atividade existe ou não a potencialidade ou o perigo abstrato de lesão não pode ser discutido no âmbito de aplicação da norma, pois constitui somente um elemento de avaliação na promulgação da norma" (HASSEMER, 1991, p. 35).

A imputação restaria facilitada porque se dispensam a prova ou a colocação de bem jurídico em perigo, porquanto bastaria a verificação do comportamento presumidamente perigoso, previamente averiguado pelo legislador, para a consumação do delito. ${ }^{101}$

Ora, conforme este raciocínio, a ideia de aplicação da pena nos limites do merecido - fim retributivo - estaria afrouxada, porque, como expõe GRACIA MARTÍN (2007, p. 67):

Enfim, e para que o viés antigarantista do modelo penal dos bens jurídicos coletivos não descumpra seu papel, os tipos, pretensamente orientados à proteção destes bens, teriam um conteúdo que - assim afirma a crítica - esgotar-se-ia com as 'meras violações de deveres', e por isso, tratar-se-ia de tipos meramente formais ou de pura desobediência. Em particular, resultariam vulnerados os princípios da lesividade e de proporcionalidade, mas também o de culpabilidade. (2007, p. 67).

Afastando a visão de perigo presumido, o crime de perigo abstrato - em uma configuração tolerável ao Direito Penal de proteção de bens jurídicos - necessita da constatação de "presença, na conduta (ex ante) de um risco real jurídico-penalmente relevante para o bem jurídico" (SILVA SÁNCHEZ, 1997, p. 1716).

Como já se fez referência, o bem jurídico protegido no âmbito do meio ambiente é de caráter difuso, o que deixa ainda mais complexa a utilização dos crimes de perigo abstrato, dada a difícil apuração se ex ante a conduta estava apta para criar risco ao impreciso bem jurídico. CORCOY BIDASOLO (2002, p. 636-638), com o objetivo de solucionar essa problemática, afirma que não se deve confundir o objeto do delito ambiental com o bem jurídico protegido; para a autora, o primeiro representa o recurso natural passível de resultado material, com a lesão direta ao ar, solo ou água; e o segundo

\footnotetext{
${ }^{101}$ Ao entender o bem jurídico do Direito Penal do meio ambiente como "la exigencia de que esos recursos sólo se contaminen de forma autorizada", MÜLLER-TUCKFELD sustenta que a consumação ocorre como o uso do meio ambiente totalmente legalizado e autorizado e, por isso, "estamos ante la penalización de la desobediencia administrativa - esto es, ante las tradicionales contravenciones -, cuya incorporación al Derecho penal sólo puede servir para magnificar tal desobediencia" (MÜLLER-TUCKFELD, 2000, p. 523).
} 
admite tão-somente o resultado jurídico, consubstanciado na afetação do equilíbrio dos sistemas naturais. ${ }^{102}$

Assim, para concretizar o bem jurídico ambiental, diminuindo sua vagueza, a autora exige a coexistência do resultado material e do resultado jurídico para a consumação do delito, de modo que a lesão ao bem jurídico difuso somente se consubstancie com a comprovação de lesão ao objeto do delito, em devida relação de causalidade, e como elemento típico ou condição de punibilidade. Apenas em um segundo momento, por imputação objetiva, deve-se averiguar se a conduta lesiva material criou perigo para o equilíbrio dos sistemas naturais - efetivamente existente antes da prática delitiva. Não se utiliza como parâmetro para mensurar o risco um hipotético equilíbrio natural perfeito e utópico: ${ }^{103}$

A conduta típica própria do delito contra o meio ambiente será aquela conduta adequada ex ante para incidir negativamente em um espaço natural, infringindo leis ou disposições gerais na matéria, a contaminação efetiva deste espaço natural será o resultado, no sentido de lesão do objeto de delito, e o injusto típico será obtido por meio de um juízo de valor sobre a potencialidade lesiva desta conduta para o equilíbrio dos sistemas naturais. (CORCOY BIDASOLO, 2002, p. 638).

Além destas dificuldades para a determinação da conduta punível, diante da construção do crime de perigo abstrato e da imprecisão do bem jurídico (que impede uma possível apuração do quantum justo de pena de natureza retribucionista), ${ }^{104}$ perdura uma incógnita que a culpabilidade não parece capaz de desvendar: a justa medida de sanção aos delitos cumulativos. ${ }^{105}$

\footnotetext{
${ }^{102}$ De forma ilustrativa, CORCOY BIDASOLO: "La conducta adecuada para contaminar supone un peligro para el bien jurídico y la contaminación del recurso natural un resultado de lesión del objeto del delito - resultado en sentido material -, a la que, en su caso, se imputara la lesión del bien jurídico" (2002, p. 636).

103 Apesar de todas as construções doutrinárias, HASSEMER critica a falta de aplicação, e afirma, metaforicamente: "Que ello alivie la presión preventiva como se pretende, está aún menos claro; ya que precisamente en el ámbito, en el que se dictan delitos de peligro abstracto con particular celo -medio ambiente y tráfico de drogas-, las quejas sobre los 'déficit en la aplicación' se han convertido en una constante música de acompañamiento" (1991, p. 35).

${ }^{104}$ Sobre o tema, ROJAS afirma: "Es imposible encontrar una escala objetiva que permita justificar que un robo debe ser 'restituido' con cierta cantidad de tiempo en prisión; es mucho más grosera la desconexión cuando se trata de delitos de peligro abstracto, donde ni siquiera hay víctimas de carne y hueso ni daños computables. En este contexto es compartible la objeción de quienes ven a la idea de retribución penal como irracional" (2000, p. 111).

${ }^{105}$ No Brasil, MACHADO tratou dos delitos cumulativos nos seguintes termos: "se referem à punição de condutas não por sua própria lesividade, mas por se almejar evitar a hipótese de sua realização massiva. Assim, cada ação isolada seria insignificante sob o ponto de vista da afetação ao bem jurídico e não teria capacidade de lesioná-lo ou colocá-lo em perigo, nem mesmo se pensarmos em termos de perigo abstrato. Ocorre que, no caso da performance generalizada dessa conduta, cada ação faria parte de uma cadeia de repetição cujo montante total é que realmente resultaria perigoso para o bem jurídico coletivo" (2005, p. 143). Acrescenta a autora que a pena imposta individualmente não se justifica em termos proporcionais, porque a conduta isoladamente considerada não acarreta lesão ou perigo para o bem jurídico (2005, p. 144).
} 
Essas ações sobrepostas voltadas ao objeto do delito contra o meio ambiente poderiam ser consideradas inofensivas se fossem consideradas isoladamente, porque não haveriam criado risco suficiente a justificar a imputação. Contudo, com a cumulação dos sucessivos riscos verificados, ainda que os sujeitos não tivessem nenhum nexo subjetivo anterior ou posterior, constatar-se-ia a produção de um significativo dano ecológico. SILVA SÁNCHEZ afirma, em outros termos, que "uma só conduta não lesiona nem põe em perigo relevante o bem jurídico, mas se sanciona porque se todos fizessem o mesmo evidentemente tal perigo aí sim se daria” (SILVA SÁNCHEZ, 1997, p. 1717). Essa abordagem, porém, omite uma métrica objetiva para a culpabilidade dos envolvidos.

\section{III.5. A reparação do dano, prevenção geral negativa e prevenção especial negativa.}

A prevenção geral negativa e a prevenção especial negativa tratam da função intimidatória da pena, entendida como medida profilática. A prevenção geral dirige-se aos cidadãos indiscriminadamente, ao passo que a prevenção especial volta-se especificamente para aqueles que já delinquiram, com o fito de evitar delitos futuros.

Nesse sentido, a sanção penal abstratamente cominada deve refletir um forte contraestímulo para que os cidadãos em geral não sejam tentados à prática de um injusto. A pena concretamente imposta ao condenado, por sua vez, há de intimidá-lo ou segregá-lo, na qualidade de uma coação psíquica, para que o imputado se abstenha da comissão do fato delituoso no futuro.

Conforme esses dois raciocínios, a pena deve ser compreendida como uma considerável desvantagem pelo infrator, que frequentemente se traduz na imposição da pena de privação de liberdade. ${ }^{106} \mathrm{O}$ que se pode observar nos delitos contra o meio

\footnotetext{
${ }^{106}$ Distinguindo um modelo dogmático de Direito Penal nuclear e Direito Penal periférico, JESÚS-MARÍA SILVA SÁNCHEZ admite o emprego de pena não privativa de liberdade (cominações de sanções patrimoniais e restritivas de direitos), como instrumento simbólico-comunicativo, para viabilizar a proteção de novas áreas na coerção penal estatal. Assim: "en la medida en que la sanción no sea privativa de libertad, sino privativa de derechos o pecuniaria, parece que no habría que exigir tan estricta afectación personal; y la imputación tampoco tendría que ser tan abiertamente personal. La ausencia de penas 'corporales' permitirá flexibilizar el modelo de imputación. Con todo, para dotar de sentido a este nivel sí sería importante que la sanción se impusiera por una instancia judicial penal, de modo que retuviera (en la medida de lo posible) los elementos de estigmatización social y de capacidad simbólico-comunicativa propios del Derecho penal" (2008b, p. 181).
} 
ambiente é que o legislador não desejou destino tão atemorizante - função intimidatória do fim preventivo geral negativo - quando o infrator busca reparar o dano.

De fato, o próprio desenvolvimento da teoria preventivo especial, conduzido pela concepção garantista, voltou-se à versão positiva de ressocialização. Nesse sentido, a inocuização perdeu força nas modificações legislativas recentes - não só nacionais ${ }^{107}$ responsáveis pela aparição de uma série de instituições que permitem abstenções de imposição ou de execução total ou parcial da pena. ${ }^{108}$ No âmbito do meio ambiente, contudo, a postura do legislador se mostra mesclada. ${ }^{109}$ Por um lado, opta-se pelo uso do Direito Penal de maneira emocional para conter os anseios populares de combate à criminalidade (GÜNTHER, 2006, p. 188), cominando sanções mais duras. Por outro, preveem-se institutos distintos da pena privativa de liberdade, como as penas restritivas de direitos $^{110}$ e a suspensão condicional da pena aos casos de condenação a privação de liberdade não superior a três anos (e não de dois anos como previsto no Código Penal), ${ }^{111}$ reduzindo a possibilidade de reclusão ao cárcere, pela comprovação de reparação dos danos ecológicos (arts. 16 e 17 da Lei n. 9.605/98). ${ }^{112}$

Diante deste panorama, é certo que os modelos de reparação e conciliação ${ }^{113}$ trazem consequências aos fins das penas. SILVA SÁNCHEZ ponderou que, em certa medida, não há necessidade de insistir em uma prevenção geral negativa ou intimidatória, quando se opta

\footnotetext{
${ }^{107}$ Ver estudo comparado das legislações internacionais sobre a importância de atos de reparação no sistema jurídico-penal em SILVA SÁNCHEZ (1998, p. 191-194).

${ }^{108}$ A exemplo dessas instituições, MIR PUIG cita a liberdade condicional e a possibilidade de substituição das penas privativas de liberdade por outras penas previstas no Código Penal espanhol, além de outras figuras processuais e penais (MIR PUIG, 2007, p. 95-96). No Brasil, ver DOTTI (1998).

109 SALVADOR NETTO retrata ambiguidade na atividade do legislador, que "ao mesmo tempo em que mantém a infração genericamente como delito, percebe que a conduta concreta muitas vezes não necessita de resposta atribuída ao nível legal. É como se o Estado, em todo o momento e de forma repetida, reafirmasse a opção pela criminalização e, logo depois, estivesse ligeiramente arrependido" (2009b, p. 319).

${ }^{110}$ Artigo $7^{\circ}$ da Lei n. 9.605/98: "As penas restritivas de direitos são autônomas e substituem as privativas de liberdade quando: I - tratar de crime culposo ou for aplicada a pena privativa de liberdade inferior a quatro anos; II - a culpabilidade, os antecedentes, a conduta social e a personalidade do condenado, bem como os motivos e as circunstâncias do crime indicarem que a substituição seja suficiente para efeitos de reprovação e prevenção do crime."

${ }_{111}$ Artigo 77 do Código Penal.

112 Artigo 16. "Nos crimes previstos nesta Lei, a suspensão condicional da pena pode ser aplicada nos casos de condenação a pena privativa de liberdade não superior a três anos." Artigo 17. "A verificação da reparação a que se refere o $\$ 2^{\circ}$ do art. 78 do Código Penal será feita mediante laudo de reparação do dano ambiental, e as condições a serem impostas pelo juiz deverão relacionar-se com a proteção ao meio ambiente".

${ }^{113}$ A Lei de Crimes Ambientais traz, em seu artigo 14, as circunstâncias que atenuam a pena: I - baixo grau de instrução ou escolaridade do agente; II - arrependimento do infrator, manifestado pela espontânea reparação do dano, ou limitação significativa da degradação ambiental causada; III - comunicação prévia pelo agente do perigo iminente de degradação ambiental; IV - colaboração com os agentes encarregados da vigilância e do controle ambiental.
} 
por uma solução aparentemente melhor para o conflito, com a reparação do delito cometido, atendendo à vítima atual (SILVA SÁNCHEZ, 1998, p. 200).

Destaca VICENTE MARTÍNEZ que "a reparação como sanção é entendida como a volta das coisas ao seu estado anterior e sua utilidade é certa quando o dano foi causado à coletividade. Esta sanção é conhecida sobretudo em matéria ambiental” (2008, p. 215).

Sobre a prevenção especial negativa - de segregação do sujeito da convivência social - nota-se que a valorização da reparação do dano se conduz em sentido contrário à execução da pena do infrator no sistema carcerário. Sua premissa de ressocialização aposta no tratamento do infrator com o assentimento "voluntário" apto a restabelecer o estado de paz social anterior à comissão do fato danoso. Cumpre notar que, apesar do caráter voluntário de reparação, isso não significa obrigatoriamente a internalização de valores sociais - prevenção especial positiva -, podendo configurar tão-somente uma alternativa para a obtenção de vantagens na execução penal. 


\section{O FIM DA PENA NOS CRIMES CONTRA O MEIO AMBIENTE}

A pergunta de qual é efetivamente o fim da pena nos crimes contra o meio ambiente ainda segue sem resposta. Se os fins tradicionais e declarados oficialmente apresentam deficiências - quando isoladamente considerados - no âmbito da proteção penal ecológica, como exposto nas considerações anteriores, ${ }^{114}$ deve existir uma função ulterior que justifique a intervenção estatal na proteção deste bem jurídico difuso. Este é o objeto do presente tópico.

ALENZA GARCÍA (2002, p. 596-597), fazendo uma análise específica do Direito Penal na seara ambiental, indica quatro funções gerais das penas previstas para os crimes contra o meio ambiente: repressiva, preventiva, reparadora e simbólica.

A primeira é a função repressiva, verificável como forma de punir as infrações já ocorridas, contrárias ao ordenamento. Configura uma resposta às condutas que vulneram os mandatos e proibições legais, sem garantir em contrapartida benefícios ao meio ambiente. A função repressiva equivale à teoria retributiva da sanção penal.

A segunda é a função preventiva, que, na mesma direção da teoria preventiva, cinde-se em duas vertentes principais (prevenção geral e prevenção especial), com o objetivo de evitar futuros delitos, seja por intimidação geral da comunidade, seja pelo medo individual do sujeito que sofreu a pena. A função preventiva corresponde, grosso modo, à teoria preventiva da sanção penal.

Sobre estas duas primeiras funções, portanto, aplicam-se as considerações gerais (capítulo 2) e críticas específicas no âmbito do Direito Penal ambiental (capítulo 3) abordadas neste trabalho. Não obstante, ALENZA GARCÍA (2002, p. 596-597) apresenta mais duas funções que podem ser estendidas às penas ambientais, e que merecem comentários detidos.

A função reparadora, própria do âmbito civil, ganha expressividade no Direito Penal frente à importância de princípios essenciais no Direito Ambiental: preservação; poluidor-pagador; e restaurabilidade. Nos crimes de menor potencial ofensivo, além das medidas normalmente impostas, os juízes ou tribunais, quando da suspensão condicional do processo, exigem laudo de constatação de reparação do dano ambiental ${ }^{115}$ para a

\footnotetext{
${ }^{114}$ É importante assinalar que as características do Direito Penal ambiental apresentadas no capítulo anterior projetam efeitos sobre os outros fins das penas, não apenas sobre os indicados em cada tópico. Em lugar de exaurir as possibilidades de inconsistência entre os fins declarados das penas e sua utilização com respeito ao meio ambiente, a intenção daquele capítulo foi destacar as deficiências a tal ponto relevantes que desencadeiam a ilegitimidade de determinados fins declarados das penas.

${ }^{115} \mathrm{Na}$ Espanha, essa medida reparadora pode ser entendida como uma medida cautelar, remédio processual para garantir as responsabilidades derivadas do delito, com o fim de restaurar o equilíbrio ecológico perturbado pelo fato. SILVA SÁNCHEZ (1999, p. 173) a aproxima de uma responsabilidade civil, pelo caráter de reparação do dano, ou de uma medida de natureza jurídico-administrativa, pela possibilidade de acordo de
} 
declaração de extinção de punibilidade, conforme disposto, por exemplo, no art. 28 da Lei n. $9.605 / 98$.

Dúvidas ainda perduram em relação ao significado dos termos de ajustamento de conduta $^{116}$ (TAC) no âmbito penal, tanto sobre sua natureza jurídica quanto sobre o grau de vinculação existente entre as esferas administrativa e penal. Diante do princípio da indisponibilidade do processo na ação penal pública, o Superior Tribunal de Justiça ${ }^{117}$ tem reiterado o entendimento de que o TAC não impede a instauração da ação penal, não sendo considerado causa de extinção da punibilidade, ${ }^{118}$ em razão da independência entre as esferas administrativa e penal.

O que merece destaque, de fato, tema deste tópico, é a última função indicada por ALENZA GARCÍA: a simbólica. Ainda que pareça próxima à função preventiva, a função simbólica da sanção penal se sobressai nos escritos doutrinários contemporâneos. ${ }^{119}$ Embora exista divergência sobre seu exato conteúdo, em linhas gerais, a função simbólica se exprime pela utilização do Direito Penal como meio de sublinhar a importância de determinadas condutas na sociedade e elevar a consideração de determinados bens jurídicos. Com esse fito, vale-se de efeitos latentes da pena, não declarados, que se sobrepõem aos efeitos manifestos da sanção penal. ${ }^{120}$

Em razão da falta de suporte nas funções tradicionais da pena para as sanções penais destinadas aos delitos contra os bens jurídicos ambientais, reconhece-se uma função simbólica, paralela, complementar ou exclusiva às funções instrumentais. É quase

ofício, sem necessidade de processo. A medida cautelar seria, pois, uma medida paralela à sanção penal, tendo o juiz a faculdade de aplicá-la ou não. Diretamente relacionada com a pena criminal, o legislador garantiu ao infrator uma alternativa de significativa diminuição da sanção e impossibilidade de impor privação de liberdade (sem arbitrariedade judicial), se estiverem comprovados os esforços posteriores em favor da reparação dos danos ao meio ambiente por sua conduta perigosa imputável objetivamente, mantendo a lógica de valorizar a restauração do meio ambiente ao status quo ante - quando possível.

${ }^{116}$ MAZZILLI apresenta as particularidades da transação e do termo de ajustamento de conduta (2007).

${ }^{117}$ Ver como exemplo acórdão do Superior Tribunal de Justiça: HC n. 82911/MG. Relator Ministro Arnaldo Esteves Lima. Quinta Turma. Julgamento: 05 de maio de 2009. Disponível em <http://www.trf3.jus.br>. Acesso em 12.11.2010.

${ }^{118}$ Alguns entendem ser o TAC causa extralegal de exclusão de antijuridicidade; outros o interpretam como forma de afastar a própria tipicidade da conduta, direcionando-se no sentido de trancamento da ação penal nos casos em que é verificado o acordo do infrator com o representante do Ministério Público, com o intuito de reparar o dano ambiental criado. Ressalta-se o posicionamento de FREITAS, ao defender a reparação do dano ambiental como causa de extinção da punibilidade, quando o Estado não apresenta mais interesse na punição do agente: “Assim, com relação ao meio ambiente, a adoção de idêntica causa [extinção da punibilidade pela reparação] seria muito importante, não só pelo que em si representa, como e principalmente, para solucionar uma questão que vem causando uma grande polêmica, ou seja, quando o agente cumpre o acordo firmado no compromisso de ajustamento de conduta firmado para reparar o dano, reparando-o integralmente e assim mesmo tem de ser submetido ao processo criminal." (2005, p. 158-159).

119 Dentre a ampla gama de autores que já tratou do tema, destacam-se HASSEMER (1991), BUSTOS RAMÍREZ (1991) e DÍEZ RIPOLLÉS (2003).

120 Sem embargo de existirem pequenos matizes entre os termos "funções manifestas", "funções instrumentais", "funções declaradas" e "funções tradicionais", destaca-se que todas indicam funções expressas que a sanção penal desempenha, em oposição às "funções latentes", "funções simbólicas", "funções não-declaradas" e "funções apócrifas". 
consensual ${ }^{121}$ a existência de uma função simbólica nas penas dos crimes contra o meio ambiente. Entretanto, antes de tratar especificamente do âmbito ecológico, merece análise o conceito de Direito Penal simbólico na doutrina.

\section{IV.1. O Direito Penal simbólico: em busca de um conceito}

\section{A) Entre o manifesto e o latente}

Embora reitere a ausência de um conceito preciso sobre Direito Penal simbólico, HASSEMER afirma que o simbólico ${ }^{122}$ está diretamente associado com o engano, de caráter negativo: 'trata-se de uma oposição entre 'realidade' e 'aparência', entre 'manifesto' e 'latente', entre o 'verdadeiramente querido' e o 'aplicado de outra forma'; e se trata sempre dos efeitos reais das leis penais" (HASSEMER, 1991, p. 28).

O autor indica uma classificação das diversas formas simbólicas de Direito, apresentando um rol de quatro alternativas: leis de declaração de valores; leis com caráter de apelação (moral); respostas substitutivas do legislador; e leis de compromisso.

Para o primeiro caso, HASSEMER (1991, p. 25-26) exemplifica com o aborto a lei de declaração de valores, que expressa qual o valor que se sobrepõe e será protegido pela norma, diante do conflito entre o direito de autodeterminação do corpo da mulher e o direito à vida de um futuro ser humano. Na classificação da lei de caráter de apelação (moral), destaca-se o Direito Penal do meio ambiente, pois sua missão é transmitir aos sujeitos uma conscientização sobre a importância de determinado valor na sociedade. No caso das leis penais ambientais, sinaliza-se para a valorização da preservação ambiental. As respostas substitutivas do legislador, também chamadas de leis de crises, são entendidas como preceitos normativos utilizados como subterfúgio para conter o medo e os protestos públicos, como se dá com a legislação contra o terrorismo. Por último, estão as leis de compromisso, expressadas por cláusulas penais gerais, que, segundo HASSEMER (1991, p. 26), "sempre têm um núcleo central para satisfazer a "necessidade de atuar"” do Estado.

121 Ver: PENA Y ESTADO (1991); CORCOY BIDASOLO (1999), SILVA SÁNCHEZ (2002); MÜLLER-TUCKFELD (2000).

${ }^{122}$ Esclarece HASSEMER (1991, p. 28) que "el propio término no ha sido objeto de estudio por la doctrina; no he encontrado un concepto preciso y apto de 'simbólico' o 'legislación simbólica'. 
As diferenças entre essas categorias são tênues, de modo que um exemplo, muitas vezes, pode localizar-se em qualquer das outras classificações, porque suas características se mesclam na conceituação do Direito Penal simbólico.

Frente à exposição de HASSEMER, é possível notar que a vinculação da norma de efeitos simbólicos não é por si só reprovável (1991, p. 25); de fato, todo o Direito Penal moderno apresenta essa característica. ${ }^{123}$ Contudo, a consideração do Direito Penal simbólico como algo negativo e criticável provém do contraste entre as funções manifestas e latentes, representado pelo componente de "engano" ou pela "falsa aparência de efetividade e instrumentalidade" (HASSEMER, 1991, p. 30).

Portanto, o sentido crítico da função simbólica se vislumbra quando se sobrepõe a função latente - de realização de algo diverso do descrito na norma, como "a satisfação de uma necessidade de atuar", "apaziguamento da população" e "demonstração de um Estado forte" - sobre a função manifesta de proteção do bem jurídico, ditada pelas condições objetivas de realização instrumental da norma.

No plano pragmático, o resultado previsto e esperado pelo ordenamento jurídico dos fins instrumentais fica em segundo plano, enquanto assoma a concretização do simbólico, daquilo não declarado formalmente. Por isso, constata-se "o engano" ou “aparência", argumentados por HASSEMER (1991, p. 30), de impossibilidade de confiar nas expectativas sinalizadas pela norma, porque os fins descritos na regulamentação se diferenciam dos que se espera na prática.

À diferença dos efeitos manifestos, que teriam a capacidade de modificar a realidade social por meio da prevenção de comportamentos indesejados aptos a lesionar o bem jurídico protegido, os efeitos simbólicos estariam conectados ao fim de transmitir à sociedade determinadas mensagens ou conteúdos valorativos, influenciando certas representações valorativas, por emoções e sentimentos.

\footnotetext{
${ }^{123} \operatorname{COSTA}(2010$, p. 110-113) traça uma distinção entre aspectos comunicativos, expressivos e simbólicos. Em linhas gerais, a autora afirma que o aspecto comunicativo representa a forma de transmissão de ideias por meio da linguagem, sendo o Direito Penal um fenômeno comunicativo. A representação simbólica-expressiva da norma é atribuída a KLAUS GÜNTHER, diante da carga expressiva e ritual que as normas penais contêm, que as distingue da mera reparação do dano. Contudo, para COSTA, o termo simbólico significa em sua obra a ideia de sobreposição de funções ou aspectos latentes sobre os manifestos, ressaltando que "sem a inerente comunicação característica da norma, não é possível a produção de aspectos latentes. Também a qualidade expressiva da norma, que é especialmente destacada no caso da norma penal, é essencial para a produção de efeitos simbólicos. Mas a norma só pode ser tida como simbólica quando, além de sua carga comunicativa e expressiva, ela apresentar funções não declaradas, que não são perceptíveis de modo imediato e prevalecem sobre as funções manifestas" COSTA (2010, p. 114).
} 
A constatação de um Direito Penal simbólico nestes termos gera inúmeros inconvenientes. $\mathrm{O}$ incômodo mais relevante assenta-se na carência de proteção real dos bens jurídicos em prol de uma ganância política por parte do legislador penal, que se exibe como ator presente, ágil e sagaz ${ }^{124}$ frente às novas preocupações da sociedade, expandindo o âmbito de atuação do Direito Penal sem seletividade. O engano do Direito Penal simbólico fomenta uma "ganância preventiva" (HASSEMER, 1991, p. 35) que superestima o potencial empírico ${ }^{125}$ de eficácia do Direito Penal, ao lhe atribuir tarefas impossíveis de serem cumpridas, gerando elevados déficits de execução que, a longo prazo, esgotam a confiança da sociedade nos órgãos de punição estatal.

\section{B) Entre os efeitos instrumentais e os expressivo-integradores}

Em trabalho de referência sobre o tema, DÍEZ RIPOLLÉS (2003) visou a afastar preconceitos incidentes sobre a terminologia, chamando os efeitos simbólicos da pena de efeitos expressivo-integradores, ${ }^{126}$ à diferença dos efeitos instrumentais. O autor diverge do exposto por HASSEMER, por crer que a função simbólica da pena também cumpre um papel de proteção dos bens jurídicos por meio da prevenção de comportamentos. Para DíEZ RIPOLLÉS (2003, p. 151), o efeito simbólico, na realidade, mostra-se essencial para obter o resultado de dita proteção. Em sua opinião:

os efeitos expressivo-integradores constituem um dos pilares
fundamentais da utilização legítima da pena, já que constituem o núcleo
da prevenção intimidatória, individual e coletiva, além de
desempenharem também o papel fundamental nas teorias preventivas que
buscam reforçar determinadas socializações ou confirmar a vigência dos
valores básicos da ordem social entre os cidadãos. (DÍEZ RIPOLLÉS, 2003,
p. 152).

${ }^{124}$ HASSEMER reforça esse entendimento: "Com efeito, é assim que a classe política pode proclamar à opinião pública que está atenta aos problemas do mundo moderno e, mais ainda, que até se compromete com a tomada de medidas drásticas para os resolver. Por outro lado, enquanto se quer fazer com que os cidadãos acreditem num direito penal do ambiente pronto para realizar milagres, espera-se também que outras preocupações, tais como o preço da gasolina, se lhes desvaneçam da idéia. Tudo isto denuncia o caracter simbólico do direito penal do ambiente, cujo verdadeiro préstimo redunda em desobrigar os poderes públicos de perseguirem uma política de proteção do ambiente efetiva" (1998, p. 33).

${ }_{125}$ Para uma discussão sobre a confirmação empírica dos fins das penas, ver HASSEMER (2005, p. 426-428).

${ }^{126}$ Sobre a classificação terminológica do autor, em suas próprias palavras: "En principio, por efecto instrumental entenderíamos aquel que supone cierta modificación de la realidad social y, más en concreto, de los comportamientos humanos; consideraríamos efecto expresivo al que suscita emociones o sentimientos en las conciencias; y estaríamos ante un efecto integrador cuando se generan determinadas representaciones valorativas en las mentes" (DÍEZ RIPOLLÉS, 2003, p. 151). 
Esse aspecto comunicativo da função simbólica seria apto a direcionar comportamentos baseados na comunicação de símbolos expressos em todas as normas jurídicas. Sob o entendimento de um instrumento comunicativo, a função simbólica não expressa necessariamente um sentido negativo para o ordenamento, por se tratar de forma objetiva da descrição do comando contido na norma penal.

Nesse sentido, a prevenção de condutas ilícitas não ocorreria tão-somente com os efeitos instrumentais, que supõem certa modificação do âmbito social, mas, na realidade, seria forjada também por efeitos simbólicos. O "monopólio semântico da utilidade" dos efeitos instrumentais (efeitos materiais) não parece verossímil ao autor (DÍEZ RIPOLLÉS, 2003, p. 152). Em outras palavras, acredita-se que os efeitos expressivos-integradores são igualmente hábeis para a realização de transformações sociais, não sendo exclusividade dos efeitos materiais.

Não haveria, pois, um problema de desajuste entre o manifesto e o latente, mas sim de incertezas a respeito da legitimidade da produção de determinados efeitos sóciopessoais. Na sua argumentação, não se deve desqualificar como simbólica uma intervenção penal que produz efeitos de prevenção de comportamentos lesivos a bens jurídicos, mesmo que os efeitos produzidos não tivessem sido queridos ou previstos (DÍEZ RIPOLLÉS, 2003, p. 163-164). Em resumo, no Direito Penal simbólico, produzem-se efeitos sócio-pessoais expressivo-integradores que não são por sua natureza ilegítimos. Tais efeitos podem, ao superar os limites utilitários da sanção penal, em determinados casos, não se ajustar às funções escolhidas na política criminal como aptas a manter a ordem social, porque incidem em elementos que não diretamente levam à lesão ou à colocação em risco do bem jurídico protegido, a proporcionalidade e a humanidade das penas (DÍEZ RIPOLLÉS, 2003, p. 164).

Independente do desacordo doutrinário sobre o momento de caracterizar a atuação estatal punitiva como simbólica, existe um consenso sobre a importância do fím utilitário, que não deve deixar de ser resguardado. Isto significa que o efeito simbólico ou expressivo-integrador pode, em algumas ocasiões, recair em esferas nas quais o Direito Penal não está legitimado a atuar ou em âmbitos de intervenção demasiado repressivos, se existe falta de cumprimento das decisões político-criminais fundamentadoras dos fins das penas ou desproporcionalidade. 


\title{
C) Entre a censura administrativa e a penal
}

Existe outra distinção sobre o termo "simbólico", que está relacionada com a diferença das sanções administrativas e outras sanções de natureza penal. A pena traz uma carga de expressividade que constitui uma reação jurídico-penal que não se iguala e não pode converter-se em simples reparação civil ou administrativa.

REALE JÚNIOR expõe que, quando se verifica a sobreposição de sanções administrativa e penal, a distinção em relação ao significado de reprovação torna-se muito sutil. Tanto em uma como em outra é possível observar fins preventivos e retributivos; o que as diferencia, pois, é o "caráter moral de reprovação social" inerente à sanção penal, assim como o ônus e encargo do processo penal ao qual é submetido o acusado, não encontráveis na seara administrativa, seja na punição ou no processo administrativo (1999b, p. 124). Conclui o autor que a distinção entre ambas está no elevado grau de censura moral do âmbito penal, ${ }^{127}$ em contraposição à censura minorada do perímetro administrativo.

Igualmente, SGUBBI aclara a semelhança dos encargos provenientes da atividade econômica:

\begin{abstract}
Sanção penal e tributo, assim, terminam coincidindo por estrutura e por função. Ambos constituem um sacrifício para o indivíduo, ditado pelo poder de império da autoridade pública em vista da obtenção de fins públicos. E, sobretudo, ambos incidem sobre o pressuposto fático de uma atividade lícita e carente de funções repressivas e de tutela direta de bens; ademais, a criação e a distribuição de ambos são o fruto de contingentes e artificiais decisões políticas socialmente negociadas. (1998, p. 90).
\end{abstract}

Essa equiparação pressupõe condutas próprias do regular exercício da atividade econômica eleitas pelo legislador - de modo forçado - como crimes. Estruturalmente, as obrigações impostas pelo Estado, no cometimento de um crime tributário ou no pagamento de tributos, são semelhantes - quando não envolvem penas privativas de liberdade -, devendo o indivíduo realizar o adimplemento da dívida com o fisco, mediante pagamento de uma quantia em dinheiro. Embora os fundamentos sejam distintos, na prática o ato do desembolso de valor é idêntico para quem paga, a se diferenciar pelo fator psicológico da censura penal e do rótulo de criminoso.

\footnotetext{
${ }^{127}$ Ao se expressar sobre a função simbólica entre os efeitos sociais empíricos do Direito Penal, destaca SILVA SÁNCHEZ que "será un proceder básicamente simbólico, y que en principio no garantizaría una mayor protección de los bienes jurídicos afectados, el trasladar al Código penal una norma ya existente en la legislación especial, sólo por el mayor efecto retórico que ello tiene” (2002, p. 305).
} 
MIR PUIG expõe que a diferença é qualitativa: a pena criminal imputa maior gravidade se comparada com a administrativa. Tal gravidade não se resume a "mais sanção", como quantidade, porque, apesar de somente o âmbito penal admitir a privação de liberdade, é possível averiguar situações nas quais a punição administrativa pecuniária é significativamente mais alta do que a multa penal. Assim, "a maior gravidade da pena criminal há de se ver, então, em termos simbólicos, por razão da censura ético-social muito maior que atinge uma condenação penal” (MIR PUIG, 2004, p. 9, grifos do autor).

Por conta da censura social existente como efeito simbólico da imposição de uma pena criminal, sua utilização deve ser cautelosa, demandando uma complexa construção jurídico-dogmática de imputação, baseada em uma política criminal estruturada em parâmetros baseados no princípio da culpabilidade e na proporcionalidade.

\section{D) Entre a função ético-social, a função simbólica e a função de satisfação de necessidades de psicologia social}

Sobre a questão do Direito Penal simbólico, SILVA SÁNCHEZ analisa se os efeitos sociais empíricos do Direito Penal - por ele classificados em função ético-social, função simbólica e função de satisfação de necessidades de psicologia social - devem ser assimilados à teoria da legitimação do Direito Penal. Em contraposição aos fins ideais justificadores da intervenção jurídico-penal legitimada (no plano do "dever ser"), estes efeitos sociais são verificados no plano empírico (2002, p. 300-310).

Pela função ético-social ou função configuradora dos costumes, compreende-se que as normas penais possuem uma função informativa, capaz de gerar eventuais consequências formativas no "mínimo ético da sociedade", ao vincular o conteúdo jurídico-penal aos valores éticos fundamentais. Verifica-se, portanto, a internalização, pela sociedade, de valores descritos na norma ${ }^{128}$ (SILVA SÁNCHEZ, 2002, p. 300).

\footnotetext{
${ }^{128}$ A respeito da influência da norma: "Es decir, que no se limitan a conseguir (en el grado que sea) una adecuación externa de las conductas de los ciudadanos a lo dispuesto en ellas, sino que provocan (también en el grado que sea) una adhesión interna, configuran las conciencias" (SILVA SÁNCHEZ, 2002, p. 300, nota de rodapé 488).
} 
Questiona-se, ademais, se o Direito pode intervir na moral pública. ${ }^{129}$ Em outras palavras, se a intervenção jurídico-penal, além de definir o injusto, determinando as condutas socialmente indesejadas, está legitimada a conduzir as consciências e convicções morais dos cidadãos, a fim de desencadear adesão e fidelidade à ordem estabelecida. ${ }^{130}$

$\mathrm{Na}$ realidade, este efeito configurador de costumes já é notado na prática. Entretanto, o que preocupa é o uso de suas consequências no discurso legitimador do Estado, ${ }^{131}$ como missão primária, principalmente quando não há clara proteção de bens jurídicos pela incriminação estatal.

Em certa medida, tal pensamento se aproxima do discurso preventivo geral positivo de simples efeito comunicativo e afirmação do ordenamento jurídico. Independente da proteção dos bens jurídicos e sem a exigência de execução da pena, a integração ou estabilização social provém da transmissão de signos comunicativos pela simples existência da norma, que exerce uma função educativa de internalização de valores do Direito nas atitudes particulares dos indivíduos. ${ }^{132}$

A política criminal liberal, que consagra a autonomia de consciência do individuo, choca-se contra a concepção de intervenção penal educativa-promocional. Esta, em lugar de recorrer a outras instâncias de controle social, impõe de forma despótica, prima ratio, valores que não estão ainda assumidos pela sociedade de forma madura ou homogênea, por

\footnotetext{
${ }^{129}$ Sob uma perspectiva criminológica, $S A$ trabalha a questão da moral e o Direito, debatendo teóricos como Durkheim, Freud, La Taille e Kohlberg (2008, p. 202-208). A respeito da esfera ambiental, explica o autor que "a moralidade heterônima é suficiente para conter os comportamentos de lesão a outros bens fundamentais, previstos no art. $5^{\circ}$ da Constituição Federal (e não raras vezes não o é). A moralidade exigida para a boa compreensão do meio ambiente como bem fundamental da humanidade e do planeta Terra, só é possível a partir de uma capacidade de 'apossamento interno' dos valores e princípios, de elaboração e resignificação dos mesmos. Se as leis, regras, imposições e ameaças de punição são eficientes para conter, na grande maioria da população, inclusive nas camadas menos cultas, os comportamentos de lesão à vida, aos costumes e à propriedade (e sabemos que nem sempre são eficientes), esta mesma eficiência por certo não se observará, em se tratando de conter comportamentos de agressão ao meio ambiente. Nesta contenção, será necessário todo um processo de conscientização, contando-se para tanto com uma autonomia das estruturas mentais aí implicadas." (2008, p. 203).

${ }^{130}$ Sobre esse assunto ANITUA manifesta-se afirmando que "as políticas penais que os diversos governos da atualidade implementam têm uma função simbólica declarada de impor valores morais tradicionais. Para isso, é utilizada a ferramenta tradicional de reprimir e, ao mesmo tempo, construir subjetividades." (2008, p. 802). Contra essa atuação, PASCHOAL ressalta que "o Direito Penal não tem e não pode ter uma função promocional. Ele não deve e não pode ser utilizado sob a desculpa de intentar-se um suposto desenvolvimento ou aprimoramento da sociedade, em razão de essa utilização poder levar a um autoritarismo." (2003, p. 123).

${ }^{131}$ A modificação da consciência social pelo legislador não está proibida, segundo entendimento de COSTA; contudo a utilização do Direito Penal "com fins puramente promocionais, educacionais ou pedagógicos" é vedada ao legislador (2010, p. 128).

${ }^{132}$ Esclarece SILVA SÁNCHEZ que "en efecto, con tal proceder se justifica la ingerencia del Derecho penal en la esfera interna (en la estructura de valores) del individuo, tratando de sustituir el orden de valores preexistente en ella por uno conforme a los valores que se plasman en el Ordenamiento jurídico" (2002, p. 302).
} 
meio de estruturas autoritárias de coação. Neste âmbito, podem-se reproduzir todas as críticas à prevenção especial positiva, em que o Estado se pretende "pedagogo" e dirigente intelectual. $^{133}$

Seguindo a classificação de SILVA SÁNCHEZ, a função simbólica ou retórica indica normas que "têm lugar não na realidade exterior (posto que não se aplicam), mas na mente dos políticos e dos eleitores. Nos primeiros, produziria a satisfação de ter feito algo; nos segundos, a impressão de ter um problema sob controle"134 (2002, p. 305). Trabalha-se portanto, principalmente, com a ilusão e a crença, pois a sociedade se tranquiliza com a produção de novos delitos ou aumento de penas por parte do legislador - que pretende mostrar-se perspicaz (HASSEMER, 1991, p. 35) - e não atenta aos resultados efetivos de diminuição da criminalidade.

SILVA SÁNCHEZ não nega a existência de aspectos simbólicos e comunicativos em todas as normas jurídico-penais. O que o autor desaprova é sua "absolutização" sem a conjugação com a função instrumental de proteção de bens jurídicos (SILVA SÁNCHEZ, 2002, p. 305), na medida em que, ao longo do tempo, produz efeitos contrários à ânsia protetiva inicial, gerando uma perda de credibilidade no ordenamento jurídico-penal pela sua inaplicação e ineficiência.

Finalmente, como último dos efeitos sociais empíricos do Direito Penal, encontrase a função de satisfação de necessidade de psicologia social, ${ }^{135}$ na qual os anseios irracionais e subconscientes da coletividade rogam pela existência de pena. ${ }^{136}$ Tal

${ }_{133}^{133}$ Conforme exposto no capítulo II (item II.4.B.b.1).

${ }^{134}$ Com essa mesma lógica, COSTA apresenta metáfora: "Se os legisladores são atores no 'teatro das ilusões' do direito simbólico, aos cidadãos cabe um papel igualmente triste, mas bastante confortável, como espectadores: triste, pois aparecem como as vítimas do engodo político; confortável, pois, como espectadores passivos, não são responsáveis pelo conteúdo e qualidade da apresentação. Desse modo, o engano travestido como direito penal simbólico se mostra interessante tanto para o enganado quanto para o enganador: ambos se sentem desobrigados de suas responsabilidades no trato da questão." (2010, p. 123).

${ }^{135} S A ́$ assim ilustra: "através das punições que exigimos sejam impostas aos 'cruéis' infratores, nós como que nos 'equilibramos' interiormente e nos reconfortamos. De fato, tudo fica como se subjetivamente resolvido: nossas fantasias carregadas de pulsões tomam forma e se concretizam, nossos desejos inconscientes e proibidos são realizados sem que nos sintamos culpados, as fantasias e desejos proibidos são exemplarmente punidos e o equilíbrio se restabelece, bem como uma espécie de "paz interior" (que paz...!)" (2008, p. 210).

${ }^{136}$ KLAUS GÜNTHER ilustra esse entendimento: "Para muitos defensores de penas mais rigorosas, o afastamento por meio da prisão é o verdadeiro sentido e fim da pena. É principalmente desse ponto de vista que aumentos drásticos de pena parecem também fazer sentido, pois quanto maior o tempo que o autor de um ilícito penal permanecer preso, maior será também o tempo em que a sociedade poderá sentir-se protegida contra ele. $O$ interesse da comunidade por segurança não aparece entre os critérios para determinação da pena, estabelecidos pela lei no $§ 46$ do Código Penal alemão, mas tampouco é expressamente excluído. Na prática de determinação da pena dos tribunais é bastante comum que o interesse por segurança da comunidade seja levado em conta - naturalmente, sempre no contexto dos fins oficiais da pena e nos limites de uma pena conforme à culpabilidade [...] Sem dúvida, o interesse por segurança parece aumentar cada vez mais e tornar-se o fundamento principal da pena" (2007, p. 139). 
perspectiva psico-social, por se valer de um sentimento ilógico de medo da sociedade, não parece compatível com uma intervenção punitiva racional, cujos contornos estão previamente estabelecidos legalmente (SILVA SÁNCHEZ, 2002, p. 307-308).

Em geral, SILVA SÁNCHEZ não afasta em absoluto os efeitos sociais empíricos da intervenção penal. Mas destaca que a justificativa do Direito Penal não pode se basear exclusivamente nestes elementos, que "devem ficar fora de toda teoria de legitimação [do Direito Penal]", (2002, p. 299).

\section{E) Síntese}

Conclui-se que são variadas as formas nas quais o Direito Penal simbólico se manifesta. ${ }^{137}$ As concepções esboçadas pela doutrina carregam tênues gradações entre estas manifestações, que se combinam e se mesclam, trazendo uma satisfação ilusória imediata à sociedade, que encobre a falta de capacidade do Estado em solucionar efetivamente os conflitos. Em diversos momentos, a quantidade de efeitos instrumentais e a quantidade de efeitos latentes - para verificar a preponderância de uma em relação à outra - não se mostram cristalinas, gerando dúvidas se, de fato, a norma analisada se caracteriza como intervenção penal simbólica. ${ }^{138}$

A divisão do Direito Penal simbólico em dois grupos (COSTA, 2010, p. 133) auxilia a análise sobre a aplicabilidade e viabilidade dessa forma de intervenção criminal na sociedade.

Sob o aspecto positivo, tem-se a utilização do Direito Penal de forma simbólica como instrumento destinado a conter os anseios populares de insegurança e exigência de

\footnotetext{
${ }^{137}$ No Brasil, em linha semelhante à apresentada por Hassemer, HELENA REGINA LOBO COSTA (2010, p. 125132) destaca, de forma didática, as formas de manifestação do Direito Penal simbólico como: (i) reconhecimento de um valor pelo legislador; (ii) leis com caráter de apelo (moral); (iii) reações substitutivas do legislador; e (iv) leis de compromisso ou de acordo. No primeiro grupo, de reconhecimento de um valor pelo legislador, o objetivo consiste em expressar uma escolha valorativa do legislador, com o fim de reforçar tais conceitos na sociedade. No segundo, de leis com caráter de apelo (moral), criam-se leis de caráter pedagógico que visam mais exprimir um determinado valor que alterar os comportamentos. Nas "reações substitutivas do legislador", o escopo é apresentar uma resposta rápida do legislador para conter os ânimos exaltados da população em relação a algum tema midiático. E, por último, as leis de compromisso ou de acordo, oriundas de posicionamentos conflitantes que acarretam a criação de uma legislação problemática quanto à sua viabilidade de aplicação e execução.

${ }^{138}$ Esse é o posicionamento de COSTA: "Conforme visto, a identificação do caráter simbólico de algumas normas penais não é, sempre, tarefa simples. Trata-se de uma distinção quantitativa, que não traz segurança e certeza em todos os casos, pois apresenta zonas de difícil caracterização.” (2010, p. 137).
} 
rápida resposta do legislador penal na solução de problemas imediatos. Nesse sentido, a imputação de crimes estaria direcionada a uma camada da sociedade que precisa internalizar valores escolhidos pelo legislador - mesmo que não haja consenso sobre sua proteção -, transformando a intervenção penal em via educativa. A expectativa de o Direito Penal deixar de alcançar somente a camada social menos abastada para incidir igualmente nas condutas dos detentores de poder (econômico) tem sido um fator de estímulo para a criação de normas ao promover, na população, uma sensação de igualdade na aplicação da lei.

A aceitação do Direito Penal simbólico, fundado exclusivamente nesses argumentos, tende a ir de encontro aos princípios basilares do Direito Penal do Estado democrático de Direito (COSTA, 2010, p. 134), de modo que a ingerência estatal nos direitos e garantias fundamentais dos indivíduos se torna excessivamente gravosa e desproporcional.

Por outro lado, na faceta negativa, o Direito Penal simbólico é empregado como parâmetro crítico de análise, a fim de verificar seu âmbito de atuação e o resultado apresentado em sua aplicação. Sob essa perspectiva, o Direito Penal simbólico cumpriria uma dupla função: (i) reconhecimento dos bens jurídicos individuais com a concomitante repulsa à proteção de bens jurídicos da seara econômica; (ii) e legitimação da lei instrumental, voltada à proteção de bens jurídicos em contraposição à lei exclusivamente simbólica. Entretanto, COSTA ressalva que podem existir normas penais simbólicas também no Direito Penal clássico e não apenas nos setores econômicos; ${ }^{139}$ e que não existe uma relação imediata entre a deslegitimação de um setor do Direito Penal e a instantânea legitimação de outro, porque o "aspecto simbólico não deve ser entendido como mero contraponto a um suposto aspecto instrumental" (2010, p. 136), mas sim como instrumento de crítica a questões específicas do Direito Penal contemporâneo.

Reitera-se que a crítica ao Direito Penal simbólico provém da crença inconsequente nos efeitos latentes produzidos pela norma penal, que paralisam soluções efetivas para os problemas encontrados e geram, ao longo do tempo, uma perda de legitimidade e

\footnotetext{
${ }^{139}$ Nas palavras de COSTA: “A idéia de direito penal simbólico não se volta, todavia, apenas a alguns setores do direito penal. Também no âmbito do chamado direito penal clássico (no sentido de Kernstrafrecht) são identificáveis normas penais simbólicas, tais como o mencionado exemplo da criminalização do aborto. Com relação a elas, a teoria sobre direito penal simbólico pode prestar sua contribuição crítica." (COSTA, 2010, p. 135-136).
} 
confiança no Direito Penal, que não encontra aplicação real e não tende a proteger o bem jurídico pretendido para melhorar efetivamente os males em questão.

Inegável que a simples criminalização de condutas, por si só, já carrega um efeito de intimidação e prevenção; contudo, a falta de efetividade dos tipos penais criados demonstra que os efeitos instrumentais foram abandonados e que apenas os efeitos latentes restaram verificados: rápida resposta do legislador; apaziguamento da insegurança popular; solução para uma questão envolvendo conflitos contrapostos; uso da imagem repressiva do Direito Penal para fortalecimento da moral etc.

Considerando que o preceito primário da norma penal apresenta elementos simbólicos, os reflexos do déficit de efetividade recaem igualmente no conteúdo e sentido da pena correlata. Se, em curto prazo, a sociedade fica reconfortada com a criação de uma normativa penal que - de forma aparente - resolve o problema, no longo prazo, constata que a esperança depositada no Direito Penal não se concretiza e que as sanções penais previstas não incidem da forma que se pretendia inicialmente. Nesse contexto, torna-se fundamental apenas que a pena simbólica expresse reprovação a determinados comportamentos, ainda que a efetiva punição nunca ocorra.

O efeito simbólico característico da sanção penal - de intervenção ríspida e gravosa do Estado sobre o cidadão em comparação às sanções não-penais - ganha contornos negativos pelo excesso de simbolismo. Em outras palavras, a ameaça própria da pena, que deveria diferenciar a sanção penal das outras formas de punição e simbolizar a proteção dos bens jurídicos mais relevantes, perde seu caráter de ameaça diante de sua inaplicabilidade no caso concreto. Os destinatários da norma, inicialmente intimidados pela prevenção geral positiva, ${ }^{140}$ ao final percebem a fraude e a manipulação geradas pela norma simbólica. Em regra, quando há condenações com base nessa legislação, visa-se à instrumentalização do acusado, com penas severas e exacerbadas, para que ele seja visto como exemplo pelos demais cidadãos.

Com isso, os fins instrumentais da pena são dilacerados, restando somente o fim simbólico. Diante de uma suposta ausência de fins retributivos e preventivos da pena, questiona-se a viabilidade de sustentar a aplicação de uma sanção penal com fins exclusivamente simbólicos.

\footnotetext{
${ }^{140}$ Neste sentido: "A defesa do uso simbólico do direito penal para a construção da identidade social, da idéia de justiça e de igualdade parece ser uma leitura errônea e simplista da teoria de prevenção geral positiva." (COSTA, 2010, p. 34).
} 
STRATENWERTH destaca, apesar de não discorrer nominalmente sobre finalidades flutuantes das penas, que a análise do caso concreto pode acarretar variadas necessidades de resposta estatal e, por conseguinte, numerosos fins da pena possíveis. ${ }^{141}$ A depender do crime em análise, existem finalidades de penas variáveis. A preocupação, contudo, de radicalizar a cisão das finalidades das penas para crimes distintos consiste em justificar um Direito Penal autoritário, dissociado de uma justificação comum das penas para os delitos de modo geral.

TOBIAS BARRETO também tratou, com habitual pioneirismo, deste tema:

A pena imposta a estes crimes [delitos que ulteriormente foram aparecendo] não pode sahir da mesma fonte, não tem o mesmo fundamento que a que se impõe aquelles primeiros [homicídio, furto e outros atos]. Assim, quando este ou aquelle estado pune, por exemplo, os attentados contra a sua integridade, contra a honra e a dignidade nacional, é claro que existe ahi outro principio determinante da pena, que não o que determina a punição do assassinato, do ferimento, do roubo etc. etc.

[...] A razão que tem a sociedade para punir o homicidio, por exemplo, não é a mesma que lhe serve de norma para decretar penas, verbi gratia, contra a rebelião, a sedição, a conspiração e outros iguaes delictos, que põem em perigo a vida de direito, que affectam, párcial ou totalmente, as condições de sua existência, ou vão de encontro a qualquer das leis do seu desenvolvimento. E neste sentido, pode-se então affirmar que, em relação a uma certa especie de crimes, o direito que a sociedade exerce com a sua punição, é justamente o direito de legitima defeza. (1926, p. 147-148)

Ainda que se admita flexibilidade na preponderância de uma finalidade em relação à outra, a dogmática penal tem de se desenvolver dentro de uma estrutura comum mínima, que não afaste totalmente a função retributiva, a preventiva e a simbólica.

São raros atualmente os posicionamentos radicais que fixam a justificativa da pena em apenas uma teoria. Em geral, tem-se optado pela teoria mista, já que, analisando separadamente cada um dos fins das penas, individualmente considerados, todos parecem

\footnotetext{
${ }^{141}$ De forma crítica STRATENWERTH expõe que "el quebrantamiento del derecho puede afectar a toda una serie de intereses legítimos, el intento de elaborarlo puede exigir igualmente el cumplimiento de múltiples necesidades que pueden reflejarse en numerosos fines de la pena posibles. Cuáles sean estas necesidades depende en gran parte de circunstancias del caso concreto: en un homicidio en estado emocional, a diferencia que en los delitos económicos, no se trata de la intimidación a terceros; en un proceso por haberse matado a quien traspasaba el muro no se trata, al igual que en el caso de autores en serie, de evitar la recaída en el delito; en el tráfico de drogas no se trata de una compensación entre autor y víctima, como quizá sí en un delito contra el patrimonio. Si se toma en serio esta variabilidad de los fines de la pena, en el fondo conocida desde hace mucho tiempo, estará además fuera de duda - en contra de todas las teorías de la unión, también de su variante 'dialéctica'-, que la discusión ulterior no puede tener el sentido de elaborar entre ellos una unidad que no esté fundamentada materialmente. Entonces, ya no será necesario, para recurrir una vez más sólo a este ejemplo, reconducir à tout prix el esfuerzo de reparar el daño a necesidades de prevención (...) En otras palabras, el discurso sobre el sentido y fin de la pena no es un negocio que estaría concluido, si hubiéramos encontrado de una vez por todas la respuesta 'correcta', sino una de aquellas tareas para la cual nunca podrá haber una solución definitiva.” (1996, p. 35-36).
} 
insuficientes para a fundamentação do Direito Penal. A combinação dos elementos legitimadores das teorias absolutas e relativas parece fazer mais sentido, para que se encontre um resultado justo e útil, que ao mesmo tempo intimide e previna o cometimento de delitos.

\section{IV.2. O efeito simbólico no âmbito jurídico-penal do meio ambiente}

Uma vez estabelecidas as linhas de definição do efeito simbólico no Direito Penal, importa averiguar seu efeito no que tange às penas dos crimes contra o meio ambiente.

O caráter simbólico da sanção penal dos delitos ambientais é tema recorrente na doutrina. MATA BARRANCO (1996, p. 28) expõe que a previsão de uma tutela ambiental no ordenamento jurídico-penal, ademais de fortalecer os efeitos de prevenção geral negativa, é capaz de gerar uma alteração de consciência popular quanto à gravidade dos danos das condutas lesivas ao equilíbrio ecológico. Desse modo, a sociedade acaba por internalizar os valores dos bens jurídicos ambientais, localizando-os na mesma hierarquia dos bens jurídicos individuais, para reafirmar e aceitar o disposto no ordenamento, por cumprimento voluntário.

Aludindo a esses efeitos ético-sociais, SILVA SÁNCHEZ (2002, p. 301-302) expõe, no mesmo sentido, uma função promocional do Direito Penal, alicerçada em uma técnica legislativa que valoriza o caráter educativo das normas criminais. Forçosamente, o legislador "pedagogo" precisa criar delitos sobre bens jurídicos que não foram, por ora, apropriados pelo mínimo ético da sociedade como passíveis de tutela essencial do Direito Penal, apesar de previstos constitucionalmente. Assim, as normas criminalizadoras assumem em primeiro lugar um papel formativo, de ordenamento comunicativo e informativo à sociedade, antes ainda de ocuparem uma função de efetiva proteção do meio ambiente. Entretanto, o autor constata certo sucesso nesta abordagem:

O legislador transborda aqui sua tradicional limitação aos bens socialmente consagrados como merecedores de tutela penal, para passar a desempenhar funções de promoção. [...] a tipificação, na forma em que se produziu na Espanha, de delitos como o crime fiscal ou contra o meio ambiente responderam, não em pouca medida, à vontade de gerar na coletividade, ou em determinados âmbitos da mesma, uma 'ética fiscal' ou uma 'ética ecológica' até então inexistente. (SILVA SÁNCHEZ, 2002, p. $302)$. 
Como a intervenção jurídico-penal possui essa característica simbólica intrínseca de comunicação de signos, SILVA SÁNCHEZ reconhece que ela contribui para a criação de uma consciência e um censura moral-social no caso das normas penais ambientais (2002, p. 301). A discussão central, porém, não reside na formação de uma consciência social ambiental, mas sim na forma pela qual ela ocorre. Em outros termos, o foco a se considerar não é tanto se o Direito Penal ambiental logra o resultado desejado e pretendido, mas de que forma o faz, com quais mecanismos, e quais justificativas são utilizadas para esse funcionamento (MÜLLER-TUCKFELD, 2000, p. 507).

Importante a constatação de $P A U L$ (1991), que indica que, ainda que o Direito Penal ambiental tenha propósitos nobres, seus efeitos são duvidosos porque esse ramo vem criando falsas experiências com signos semânticos enganosos, que resultam na constituição de um direito sem força, distanciado do caráter instrumental, e cujas normas penais possuem somente caráter simbólico. ${ }^{142} \mathrm{O}$ autor descreve um sistema de "organizada irresponsabilidade", em que existem abundantes legislações protetoras, porém debilmente aplicadas, porque “os símbolos jurídicos possuem uma função manipulativa. Criam deslumbramento, tranquilidade e ilusões. Estes representam uma ficta realidade e estruturam uma falsa consciência forjada igualmente de auto-engano" (PAUL, 1991, p. 122). Em consequência, os aplicadores do direito passam de autores a vítimas de suas interpretações simbólicas sobre a real situação do meio ambiente, visto que se iludem quanto à efetiva resolução do problema.

Ainda sob essa perspectiva, BUSTOS RAMÍREZ (1991), ao indicar os efeitos da função simbólica, acrescenta que, além de falsear a capacidade do Estado para a efetiva resolução de problemas ambientais, o Direito Penal ambiental produz uma aparente sensação de igualdade, por ampliar seu poder de intervenção inclusive às camadas mais opulentas da população, não se restringindo aos indivíduos pobres usualmente responsabilizados nos crimes contra o patrimônio - ainda que essas novas criminalizações não resultem em efetiva punição dos novos agentes, frente à inaplicabilidade da norma.

Portanto, longe de estar isenta de riscos e críticas, esta função simbólica também tem sido acusada de causar mais danos que benefícios (MATA BARRANCO, 1996, p. 33), ao

\footnotetext{
${ }^{142}$ Assim: "en este contexto, de ineficacia del Derecho penal medioambiental, se afirma que estamos ante un caso paradigmático del Derecho penal simbólico en el que la tutela penal del medio ambiente sirve para engañar la opinión pública, aunque lo mismo contribuye también a la toma de consciencia por parte de la población acerca del reconocimiento del medio ambiente como un interés fundamental para el desarrollo de la vida en sociedad" (BARREIRO, 2005, p. 20).
} 
se ocupar de tranquilizar a sociedade e de justificar a atuação da classe política, embora não produza efetivos resultados com a incriminação, deixando, portanto, de indicar ou de auxiliar na criação de mecanismos aptos a combater a degradação ambiental.

Não obstante, autores como CORCOY BIDASOLO (2000) defendem que, excetuados os casos em que a função simbólica dificulta a aplicação de outros âmbitos de proteção, ela resulta necessária por manifestar o reconhecimento institucional da existência de interesses básicos para o desenvolvimento da vida em sociedade. Para os crimes relativos ao meio ambiente, a criação de novas condutas proibidas, por via da função simbólica da norma penal, serve não só para generalizar a convicção entre os cidadãos da grave reprovabilidade da degradação ambiental e dissuadi-los da sua comissão, mas também para imbuir os juízes da relevância deste interesse coletivo e da necessidade de impor as correspondentes sanções, especialmente naqueles âmbitos, como o ambiental, nos quais ainda não existe uma consciência social solidamente arraigada (CORCOY BIDASOLO, 2000, p. 77).

De modo análogo, SCHÜNEMANN, reprovando a posição da tradicional escola de Frankfurt, que clama pela substituição do Direito Penal ambiental pela proteção administrativa, entende que no âmbito ecológico a intervenção penal não pode abdicar de seu efeito de prevenção geral positiva ou integradora, de formação de uma consciência comunicativa favorável aos valores ecológicos (2002, p. 222). O autor considera ingênuo o movimento de mudança de consciência a partir da descriminalização, por julgar que a transformação do Direito Penal do meio ambiente em instrumento sem eficácia não deve ser resolvida com a supressão dos crimes já existentes, mas com seu emprego efetivo, para reconquistar a credibilidade das norma penais (SCHÜNEMANN, 2002, p. 222).

Já advertiu SILVA SÁNCHEZ que, na sociedade contemporânea, com a utilização do Direito Penal como meio de transformação da moral social, os processos de despenalização ou não-tipificação podem gerar efeitos negativos, no sentido de a sociedade não mais encarar os fatos descriminalizados como reprováveis (2002, p. 303). Por isso, "uma eventual renúncia ao Direito Penal do meio ambiente se interpretaria como um retrocesso inadmissível da política ambiental" (MÜLLER-TUCKFELD, 2000, p. 529).

Talvez, para fugir da encruzilhada ${ }^{143}$ entre, de um lado, uma descriminalização temerária e, de outro, a manutenção de um Direito Penal sem efeitos instrumentais, a

\footnotetext{
${ }^{143}$ Nessa perspectiva, GARLAND ressalta o dilema das autoridades governamentais de abandonar o papel de provedor primário e eficaz de segurança e controle do crime e os custos políticos que tal abandono pode acarretar, destacando que "o resultado é uma série de políticas esquizofrênicas, que parecem conflitar entre
} 
alternativa seja buscar uma interpretação que reduza ao máximo seu âmbito de aplicação, partindo de uma concepção subsidiária de atuação. Embora não seja objeto deste trabalho, esta possibilidade foi aventada por diversos autores. ${ }^{144}$

\section{IV.3. A tutela penal do bem ambiental e o princípio da intervenção mínima}

Dada a impossibilidade de admitir a abolição completa do Direito Penal ambiental, ROXIN (2003), por exemplo, parte da concepção de Direito Penal mínimo, de atuação subsidiária, na qual as alternativas à intervenção penal parecem sempre mais benéficas na medida em que não estão atreladas às cargas e repercussões sociais negativas como no Direito Penal, e tampouco incidem na esfera de dignidade do indivíduo de maneira intensa.

ROXIN assinala quatro alternativas, que podem ser transladadas ao Direito Penal do meio ambiente. A primeira consiste no tradicional princípio da subsidiariedade, esboçado nas linhas anteriores, sem embargo com uma visão interdisciplinar, para que "antes de introduzir novos preceitos penais - e também em relação às normas penais já existentes os penalistas, em colaboração com representantes de outras ciências e mediante o exame do repertório completo de possibilidades preventivas, teriam que buscar alternativas ao castigo penal ou possibilidades de limitar os comportamentos cominados com uma pena" (ROXIN, 2003, p. 323). Esse necessário diálogo entre os diferentes âmbitos deve ser perseguido para garantir sistematicidade e unidade do sistema preventivo e punitivo. ${ }^{145}$

Uma segunda alternativa à pena estaria em uma das supostas funções do Direito Penal ambiental: a progressiva integração da reparação. $O$ anseio pela restauração do meio

si. [...] Ou nega abertamente o dilema e reafirma o velho mito do Estado soberano e seu poder punitivo pleno, ou abandona a ação racional, instrumental, retraindo-se a um estado expressivo, que talvez possamos, parafraseando a metáfora psicanalítica, descrever como autuação simbólica - um Estado que não se preocupa tanto com o controle do crime, mas sim em expressar a raiva e indignação que o crime provoca. São este dilema e as reações oficiais profundamente ambivalentes a ele - em lugar de qualquer programa coerente ou estratégia específica - que têm informado o controle do crime e a justiça criminal no período pós-moderno." (2008, p. 249-250, grifos do autor).

144 Posiciona-se REALE JÚNIOR (2005, p. 70-71) que "a intervenção penal, malgrado a determinação constitucional, deve se ater, tão só, aos fatos manifestamente mais graves, quanto ao bem jurídico ao modo como é atingido esse bem jurídico, como dimensão lesiva de grau mais elevado, sem se pretender que o Direito Penal exerça uma função simbólica de cunho mera e presuntivamente preventivo". Ver também COSTA (2010).

${ }^{145}$ MACHADO pondera a importância de uma análise prévia para uma administrativização do Direito Penal, considerando quatro situações: "as possibilidades e limites de determinada esfera jurídica para lidar com o problema, as deficiências de um modelo de regulação específico, os déficits de implementação do modelo e, por fim, o desvio ou a fraude na atuação de determinados operadores" $(2009$, p. 91). 
ambiente pode ser uma opção para abdicar da sanção penal se existem esforços do infrator na recuperação do status quo ante do meio ambiente. Essa tentativa de restauração ambiental cumpre a função preventiva geral positiva, porquanto capaz de reparar o dano social de forma satisfatória, facilitando inclusive a reparação de efeitos civis. "Evidentemente, a reparação voluntária não é um remédio genérico, porque não pode substituir a pena nos delitos graves, somente pode atenuá-la (ou em todo caso permitir a remissão condicional)" (ROXIN, 2003, p. 324).

Em terceiro lugar, ROXIN relembra alternativas para a suspensão da pena formal, considerando que, em diversos casos, em especial para aqueles que envolvem pessoas que não são infratores habituais, todo o processo de instrução penal já traz uma carga negativa suficiente (2003, p. 324).

Por último, considerando-se que existe uma internalização na população de valores essenciais, é importante que haja prevenção mediante intensa vigilância social, com o intuito de evitar o uso de vigilância tecnológica, ${ }^{146}$ que pode ser demasiadamente limitadora da liberdade do cidadão.

Em suma, a intervenção da tutela penal sobre o bem jurídico ambiental merece atenta análise do princípio da intervenção mínima, com o fim precípuo de garantir a harmonia do sistema, evitando totalitarismos ou excessos. A não intervenção penal sobre determinadas condutas não deve ser interpretada como ignorância a um dano causado, visto que outros mecanismos menos gravosos podem ser utilizados, de maneira eficaz, para a prevenção e retribuição da infração. Por essa razão, ao estabelecer o bem jurídico dotado de dignidade penal para constituir o conceito material de crime, deve-se atentar para a necessidade da tutela penal, a ser aplicada de forma subsidiária. ${ }^{147}$

O Direito Penal prevê regras de convivência e pacificação necessárias à vida em sociedade, utilizando-se de instrumentos que visam ao impedimento de práticas de fatos sociais reprováveis, considerados delituosos ou socialmente desajustados, em concordância a uma política criminal dotada de sanções penais que limitam direitos e garantias

\footnotetext{
${ }^{146} \mathrm{O}$ autor exemplifica com "los diversos métodos de investigación computerizados de que hoy disponemos, las distintas formas de vigilancia acústica y óptica, las posibilidades que abren las investigaciones moleculares genéticas y muchas otras más podrían impedir los delitos con su empleo extensivo de forma eficaz" (ROXIN, 2003, p. 324).

${ }^{147}$ Neste sentido: “A violação de um bem jurídico penal não basta para desencadear a intervenção, antes se requerendo que esta seja absolutamente indispensável à livre realização da personalidade de cada um na comunidade. Nessa precisa acepção o direito penal constitui, na verdade, a ultima ratio da política social e a sua intervenção é de natureza definitivamente subsidiária” (DIAS, 1999, p. 78-79).
} 
individuais em busca da paz social como meio para contribuir para preservação de um determinado modelo de sociedade. É considerado, por isso, o mais forte instrumento de poder punitivo utilizado pelo Estado.

O princípio da intervenção mínima não é expresso no ordenamento jurídico vigente, seja na Constituição Federal, seja no Código Penal Brasileiro. ${ }^{148}$ Trata-se de uma linha mestra imanente ao Direito Penal, ${ }^{149}$ em que a limitação do poder punitivo decorre naturalmente da política criminal. ${ }^{150}$ Este princípio está diretamente relacionado ao binômio subsidiariedade ${ }^{151}$ e fragmentariedade. O caráter subsidiário radica-se na concepção de que a atuação do Direito Penal somente se deve realizar quando todas as outras medidas de controle social fracassarem. A insuficiência dos demais mecanismos de intervenção - sociais ou jurídicos - justifica a intervenção da esfera penal, visto que a sua sanção concebe-se como a mais enérgica existente. Por sua vez, do caráter fragmentário decorrem os requisitos para a seleção dos bens jurídicos a serem protegidos, visto que a atuação do Direito Penal não visa a tutelar todas as ações ou omissões lesivas a quaisquer bens jurídicos. ${ }^{152} \mathrm{O}$ Direito Penal não pode se transformar em mero expediente corriqueiro,

\footnotetext{
${ }^{148}$ No âmbito internacional, o princípio da intervenção mínima encontra raiz na Declaração dos Direitos do Homem e do Cidadão: XV: A lei não deve discernir senão penas estritamente e evidentemente necessárias: As penas devem ser proporcionais ao delito e úteis à sociedade.

149 Deste modo, além de delimitar a esfera de atuação coercitiva estatal, que ao "relacionar o direito penal com o Estado e seu regime sócio-político coloca, além da questão de como punir, o que punir. Vale dizer, num Estado que se pretenda democrático, no qual o dissenso quanto às regras de comportamento - desde que não nocivas a terceiros ou à coletividade como um todo - aparece como nota característica, torna-se inaceitável a utilização indiscriminada do sistema punitivo para o exercício do controle social. Este instrumental deve ficar reservado como uma espécie de último argumento e, ainda assim, sempre restrito aos aspectos que tocam a coletividade ou a terceiros individualmente considerados" evita a insegurança que a arbitrariedade poderia proporcionar (TORON, 1996, p. 39).

${ }^{150}$ Segundo ANTONIO GARCIA-PABLOS DE MOLINA (1992, p. 120-121): "a Política Criminal é concebida como disciplina que oferece aos Poderes Públicos as opções científicas concretas mais adequadas para o eficaz controle do crime e estuda as alternativas legais". No Estado democrático de Direito viu-se a necessidade de associar a Política Criminal com aspectos provenientes da análise de criminologia e ciências sociais, constituindo assim uma dogmática crítica. Nas palavras de MUÑOZ CONDE: "O princípio da intervenção mínima se converte, assim, num princípio político-criminal limitador do poder punitivo do estado" (MUNÕZ CONDE, 1975, p. 71).

${ }^{151}$ Assim, "o Direito Penal não é o único controle social formal dotado de recursos coativos, embora seja o que disponha, nessa matéria, dos instrumentos mais enérgicos e traumáticos. A gravidade intrínseca desse instrumental, posto à disposição do Direito Penal, recomenda, no entanto, que só se faça dele uso quando não tenham tido êxito os meios coativos menos gravosos, de natureza não penal. A cirurgia penal, por seus efeitos traumáticos e irreversíveis - possui a nocividade intrínseca - só pode ser prescrita: in extremis, isto é, quando não se dispõe de outras possíveis técnicas de intervenção ou quando estas resultam inefícazes: como ultima ratio. O princípio da subsidiariedade limita, portanto, o ius puniendi na medida em que só autoriza a intervenção penal se não houver outro tipo de intervenção estatal menos lesiva e menos custosa aos direitos individuais" (FRANCO, 2000, p. 66).

${ }^{152}$ Cf. FRANCO: "Não basta que se demonstre ser o controle social penal um mecanismo formalizado, em face do princípio da legalidade, nem que tal controle se realize a partir de fatos concretos, comissivos ou omissivos, que lesem ou ponham em perigo bens jurídicos fundamentais para a pessoa humana ou para a sociedade em que está inserida." (2000, p. 64).
} 
cujo uso comum tangencie todos os bens jurídicos existentes, na ocorrência de qualquer conflito social. Sua atuação caracteriza-se pela intervenção traumática, com efeitos irreversíveis; deste modo, compete a essa tutela lobrigar limites materiais de atuação do poder punitivo, tanto pelo conteúdo legislativo como pela extensão de sua interpretação, para abarcar unicamente a garantia dos bens jurídicos fundamentais dos ataques a eles mais gravosos (BATISTA, 2001, p. 61).

Equívoco usualmente constatado verifica-se quando já existe um instrumento de proteção de bens jurídicos por mecanismos de natureza não penal, cuja estrutura administrativa ineficiente não garante a devida eficácia das sanções previstas. Como consequência, criam-se tipos penais novos, com a ilusão de que esta esfera saciará a deficiência burocrática e técnico-administrativa. O engano cinde-se em dois: primeiro, identifica-se erroneamente a inoperância da estrutura administrativa como resultado de insuficiência da sanção estabelecida. Não se justifica aplicar o recurso mais grave quando se obtém o mesmo resultado por meio de um mais suave. ${ }^{153}$ Ademais, a equivocada inflação legislativa ${ }^{154}$ provém da crença no Direito Penal simbólico, diante de uma desconsideração do princípio da intervenção mínima e do descrédito gestado da morosidade das autoridades administrativas ${ }^{155}$ ou do Poder Judiciário.

No caso específico do Direito Penal ambiental, a existência de uma proteção idêntica na esfera administrativa pode ser averiguada pelo quadro abaixo, que traz um paralelo entre os crimes previstos na Lei n. 9.605/98 e as infrações administrativas existentes no ordenamento jurídico brasileiro.

Art. 29. Matar, perseguir, caçar, apanhar, utilizar espécimes da fauna silvestre, nativos ou em rota migratória, sem a devida permissão, licença ou autorização da autoridade competente, ou em desacordo com a obtida:
Art. 24. ${ }^{156}$ Matar, perseguir, caçar, apanhar, coletar, utilizar espécimes da fauna silvestre, nativos ou em rota migratória, sem a devida permissão, licença ou autorização da autoridade competente, ou em desacordo com a obtida:

\footnotetext{
${ }^{153}$ Nas palavras de FRAGOSO, "uma política criminal moderna orienta-se no sentido da descriminalização e da desjudicialização, ou seja, no sentido de contrair ao máximo o sistema punitivo do Estado, dele retirando todas as condutas anti-sociais que podem ser reprimidas e controladas sem o emprego de sanções criminais", isto é, no sentido de uma "conselheira da sanção não penal" (1985, p. 17).

${ }^{154}$ DOTTI comenta sobre o assunto: "Sob outro ângulo, a inflação legislativa é uma das conseqüências da hipercriminalização e assim vem ocorrendo no Brasil por força da legislação extravagante destinada a apurar interesses coletivos no campo da economia e das finanças. Além da criação de novos tipos legais de ilicitude sem a técnica adequada, muitas leis e decretos-leis dos anos 60 e 70 previram hipóteses de infrações administrativas ou fiscais para a sujeição de seus responsáveis a medidas extra-penais" (1999, p. 63).

${ }^{155}$ Nos dizeres de MIGUEL REALE JÚNIOR, a ilusão penal é "o imaginário de poder afastar, por via da ameaça criminal, fatos lesivos de qualquer quilate, decorre, de um lado, da desconfiança da sociedade em relação a si mesma, às autoridades e às normas da Administração, acreditando-se que só serão respeitadas se houver a intimidação da sanção penal" (1999a, p. 121).

${ }^{156}$ Decreto n. 6.514, de 22 de julho de 2008.
} 


\begin{tabular}{|c|c|}
\hline Pena - detenção de seis meses a um ano, e multa. & $\begin{array}{l}\text { Multa de: } \\
\text { I - R\$ 500,00 (quinhentos reais) por indivíduo de } \\
\text { espécie não constante de listas oficiais de risco ou } \\
\text { ameaça de extinção; } \\
\text { II - R\$ 5.000,00 (cinco mil reais), por indivíduo de } \\
\text { espécie constante de listas oficiais de fauna brasileira } \\
\text { ameaçada de extinção, inclusive da Convenção de } \\
\text { Comércio Internacional das Espécies da Flora e } \\
\text { Fauna Selvagens em Perigo de Extinção - CITES. }\end{array}$ \\
\hline $\begin{array}{l}\S 1^{\circ} \text { Incorre nas mesmas penas: } \\
\text { I - quem impede a procriação da fauna, sem licença, } \\
\text { autorização ou em desacordo com a obtida; }\end{array}$ & $\begin{array}{l}\S 3^{0} \text { Incorre nas mesmas multas: } \\
\text { I - quem impede a procriação da fauna, sem licença, } \\
\text { autorização ou em desacordo com a obtida; }\end{array}$ \\
\hline $\begin{array}{l}\text { II - quem modifica, danifica ou destrói ninho, abrigo } \\
\text { ou criadouro natural; }\end{array}$ & $\begin{array}{l}\text { II - quem modifica, danifica ou destrói ninho, abrigo } \\
\text { ou criadouro natural; ou }\end{array}$ \\
\hline $\begin{array}{l}\text { III - quem vende, expõe à venda, exporta ou adquire, } \\
\text { guarda, tem em cativeiro ou depósito, utiliza ou } \\
\text { transporta ovos, larvas ou espécimes da fauna } \\
\text { silvestre, nativa ou em rota migratória, bem como } \\
\text { produtos e objetos dela oriundos, provenientes de } \\
\text { criadouros não autorizados ou sem a devida } \\
\text { permissão, licença ou autorização da autoridade } \\
\text { competente. }\end{array}$ & $\begin{array}{l}\text { III - quem vende, expõe à venda, exporta ou adquire, } \\
\text { guarda, tem em cativeiro ou depósito, utiliza ou } \\
\text { transporta ovos, larvas ou espécimes da fauna } \\
\text { silvestre, nativa ou em rota migratória, bem como } \\
\text { produtos e objetos dela oriundos, provenientes de } \\
\text { criadouros não autorizados, sem a devida permissão, } \\
\text { licença ou autorização da autoridade ambiental } \\
\text { competente ou em desacordo com a obtida. }\end{array}$ \\
\hline $\begin{array}{l}\S 2^{\circ} \text { No caso de guarda doméstica de espécie silvestre } \\
\text { não considerada ameaçada de extinção, pode o juiz, } \\
\text { considerando as circunstâncias, deixar de aplicar a } \\
\text { pena. }\end{array}$ & $\begin{array}{l}\S 4^{0} \text { No caso de guarda doméstica de espécime } \\
\text { silvestre não considerada ameaçada de extinção, pode } \\
\text { a autoridade competente, considerando as } \\
\text { circunstâncias, deixar de aplicar a multa, em analogia } \\
\text { ao disposto no } \S 20 \text { do art. } 29 \text { da Lei n. } 9.605 \text {, de } \\
1998 \text {. }\end{array}$ \\
\hline $\begin{array}{l}\S 3^{\circ} \text { São espécimes da fauna silvestre todos aqueles } \\
\text { pertencentes às espécies nativas, migratórias e } \\
\text { quaisquer outras, aquáticas ou terrestres, que tenham } \\
\text { todo ou parte de seu ciclo de vida ocorrendo dentro } \\
\text { dos limites do território brasileiro, ou águas } \\
\text { jurisdicionais brasileiras. }\end{array}$ & $\begin{array}{l}\S 7^{0} \text { São espécimes da fauna silvestre, para os efeitos } \\
\text { deste Decreto, todos os organismos incluídos no reino } \\
\text { animal, pertencentes às espécies nativas, migratórias } \\
\text { e quaisquer outras não exóticas, aquáticas ou } \\
\text { terrestres, que tenham todo ou parte de seu ciclo } \\
\text { original de vida ocorrendo dentro dos limites do } \\
\text { território brasileiro ou em águas jurisdicionais } \\
\text { brasileiras. }\end{array}$ \\
\hline $\begin{array}{l}\text { Art. 30. Exportar para o exterior peles e couros de } \\
\text { anfíbios e répteis em bruto, sem a autorização da } \\
\text { autoridade ambiental competente: } \\
\text { Pena - reclusão, de um a três anos, e multa. }\end{array}$ & $\begin{array}{l}\text { Art. } 18 .{ }^{157} \text { É proibida a exportação para o Exterior, de } \\
\text { peles e couros de anfíbios e répteis, em bruto. }\end{array}$ \\
\hline $\begin{array}{l}\text { Art. 31. Introduzir espécime animal no País, sem } \\
\text { parecer técnico oficial favorável e licença } \\
\text { expedida por autoridade competente: } \\
\text { Pena - detenção, de três meses a um ano, e multa. }\end{array}$ & $\begin{array}{l}\text { Art. 25. Introduzir espécime animal no País, ou } \\
\text { fora de sua área de distribuição natural, sem } \\
\text { parecer técnico oficial favorável e licença } \\
\text { expedida pela autoridade ambiental competente: } \\
\text { Art. } 25{ }^{158} \text { Introduzir espécime animal silvestre, } \\
\text { nativo ou exótico, no País ou fora de sua área de } \\
\text { distribuição natural, sem parecer técnico oficial } \\
\text { favorável e licença expedida pela autoridade } \\
\text { ambiental competente, quando exigível: } \\
\text { Multa de R\$ } 2.000,00 \text { (dois mil reais), com } \\
\text { acréscimo por exemplar excedente de: }\end{array}$ \\
\hline
\end{tabular}

${ }^{157}$ Lei n. 5.197, de 3 de janeiro de 1967.

${ }^{158}$ Decreto n. 6.514, de 22 de julho de 2008. 


\begin{tabular}{|c|c|}
\hline & $\begin{array}{l}\text { I - R\$ } 200,00 \text { (duzentos reais), por indivíduo de } \\
\text { espécie não constante em listas oficiais de espécies } \\
\text { em risco ou ameaçadas de extinção; } \\
\text { II - R\$ } 5.000,00 \text { (cinco mil reais), por indivíduo de } \\
\text { espécie constante de listas oficiais de fauna } \\
\text { brasileira ameaçada de extinção, inclusive da } \\
\text { CITES. }\end{array}$ \\
\hline $\begin{array}{l}\text { Art. 32. Praticar ato de abuso, maus-tratos, ferir ou } \\
\text { mutilar animais silvestres, domésticos ou } \\
\text { domesticados, nativos ou exóticos: } \\
\text { Pena - detenção, de três meses a um ano, e multa. }\end{array}$ & $\begin{array}{l}\text { Art. } 29 .{ }^{159} \text { Praticar ato de abuso, maus-tratos, ferir } \\
\text { ou mutilar animais silvestres, domésticos ou } \\
\text { domesticados, nativos ou exóticos: } \\
\text { Multa de R\$ } 500,00 \text { (quinhentos reais) a R } \$ \\
3.000,00 \text { (três mil reais) por indivíduo. }\end{array}$ \\
\hline $\begin{array}{l}\S 1^{\circ} \text { Incorre nas mesmas penas quem realiza } \\
\text { experiência dolorosa ou cruel em animal vivo, } \\
\text { ainda que para fins didáticos ou científicos, } \\
\text { quando existirem recursos alternativos. } \\
\S 2^{\circ} \text { A pena é aumentada de um sexto a um terço, } \\
\text { se ocorre morte do animal. }\end{array}$ & \\
\hline $\begin{array}{l}\text { Art. 33. Provocar, pela emissão de efluentes ou } \\
\text { carreamento de materiais, o perecimento de } \\
\text { espécimes da fauna aquática existentes em rios, } \\
\text { lagos, açudes, lagoas, baías ou águas jurisdicionais } \\
\text { brasileiras: } \\
\text { Pena - detenção, de um a três anos, ou multa, ou } \\
\text { ambas cumulativamente. }\end{array}$ & $\begin{array}{l}\text { Art. } 62 .{ }^{160} \text { Incorre nas mesmas multas do art. } 61 \\
\text { quem: } \\
\text { VIII - provocar pela emissão de efluentes ou } \\
\text { carreamento de materiais o perecimento de } \\
\text { espécimes da biodiversidade. }\end{array}$ \\
\hline $\begin{array}{l}\text { Parágrafo único. Incorre nas mesmas penas: } \\
\text { I - quem causa degradação em viveiros, açudes ou } \\
\text { estações de aqüicultura de domínio público; }\end{array}$ & $\begin{array}{l}\text { Art. } 34{ }^{161} \text { Causar degradação em viveiros, açudes } \\
\text { ou estação de aqüicultura de domínio público: } \\
\text { Multa de } \mathrm{R} \$ 5.000,00 \text { (cinco mil reais) a } \mathrm{R} \$ \\
500.000,00 \text { (quinhentos mil reais). }\end{array}$ \\
\hline $\begin{array}{l}\text { II - quem explora campos naturais de } \\
\text { invertebrados aquáticos e algas, sem licença, } \\
\text { permissão ou autorização da autoridade } \\
\text { competente; }\end{array}$ & $\begin{array}{l}\text { Art. 39. }{ }^{162} \text { Explorar campos naturais de } \\
\text { invertebrados aquáticos e algas, bem como recifes } \\
\text { de coral sem autorização do órgão ambiental } \\
\text { competente ou em desacordo com a obtida: } \\
\text { Multa de } \mathrm{R} \$ 500,00 \text { (quinhentos reais) a } \mathrm{R} \$ \\
50.000,00 \text { (cinqüenta mil reais), com acréscimo de } \\
\mathrm{R} \$ 20,00 \text { (vinte reais) por quilo ou espécime do } \\
\text { produto. }\end{array}$ \\
\hline $\begin{array}{l}\text { III - quem fundeia embarcações ou lança detritos } \\
\text { de qualquer natureza sobre bancos de moluscos ou } \\
\text { corais, devidamente demarcados em carta náutica. }\end{array}$ & $\begin{array}{l}\text { Parágrafo único. Incorre nas mesmas multas } \\
\text { quem: } \\
{[\ldots]} \\
\text { II - fundeia embarcações ou lança detritos de } \\
\text { qualquer natureza sobre bancos de moluscos ou }\end{array}$ \\
\hline
\end{tabular}

\footnotetext{
${ }^{159}$ Decreto n. 6.514, de 22 de julho de 2008.

${ }^{160}$ Decreto n. 6.514, de 22 de julho de 2008.

${ }^{161}$ Decreto n. 6.514, de 22 de julho de 2008.

${ }^{162}$ Decreto n. 6.514, de 22 de julho de 2008.
} 


\begin{tabular}{|c|c|}
\hline & corais, devidamente demarcados em carta náutica. \\
\hline $\begin{array}{l}\text { Art. 34. Pescar em período no qual a pesca seja } \\
\text { proibida ou em lugares interditados por órgão } \\
\text { competente: } \\
\text { Pena - detenção de um ano a três anos ou multa, ou } \\
\text { ambas as penas cumulativamente. }\end{array}$ & $\begin{array}{l}\text { Art. } 35 .{ }^{163} \text { Pescar em período ou local no qual a } \\
\text { pesca seja proibida: } \\
\text { Multa de R\$ } 700,00 \text { (setecentos reais) a } \mathrm{R} \$ \\
100.000,00 \text { (cem mil reais), com acréscimo de } \mathrm{R} \$ \\
20,00 \text { (vinte reais), por quilo ou fração do produto } \\
\text { da pescaria, ou por espécime quando se tratar de } \\
\text { produto de pesca para uso ornamental. }\end{array}$ \\
\hline $\begin{array}{l}\text { Parágrafo único. Incorre nas mesmas penas quem: } \\
\text { I - pesca espécies que devam ser preservadas ou } \\
\text { espécimes com tamanhos inferiores aos } \\
\text { permitidos; }\end{array}$ & $\begin{array}{l}\text { Parágrafo único. Incorre nas mesmas multas } \\
\text { quem: } \\
\text { I - pesca espécies que devam ser preservadas ou } \\
\text { espécimes com tamanhos inferiores aos } \\
\text { permitidos; }\end{array}$ \\
\hline $\begin{array}{l}\text { II - pesca quantidades superiores às permitidas, ou } \\
\text { mediante a utilização de aparelhos, petrechos, } \\
\text { técnicas e métodos não permitidos; }\end{array}$ & $\begin{array}{l}\text { II - pesca quantidades superiores às permitidas ou } \\
\text { mediante a utilização de aparelhos, petrechos, } \\
\text { técnicas e métodos não permitidos; }\end{array}$ \\
\hline $\begin{array}{l}\text { III - transporta, comercializa, beneficia ou } \\
\text { industrializa espécimes provenientes da coleta, } \\
\text { apanha e pesca proibidas. }\end{array}$ & $\begin{array}{l}\text { III - transporta, comercializa, beneficia ou } \\
\text { industrializa espécimes provenientes da coleta, } \\
\text { apanha e pesca proibida; }\end{array}$ \\
\hline $\begin{array}{l}\text { Art. 35. Pescar mediante a utilização de: } \\
\text { I - explosivos ou substâncias que, em contato com } \\
\text { a água, produzam efeito semelhante; } \\
\text { II - substâncias tóxicas, ou outro meio proibido } \\
\text { pela autoridade competente: } \\
\text { Pena - reclusão de um ano a cinco anos. }\end{array}$ & 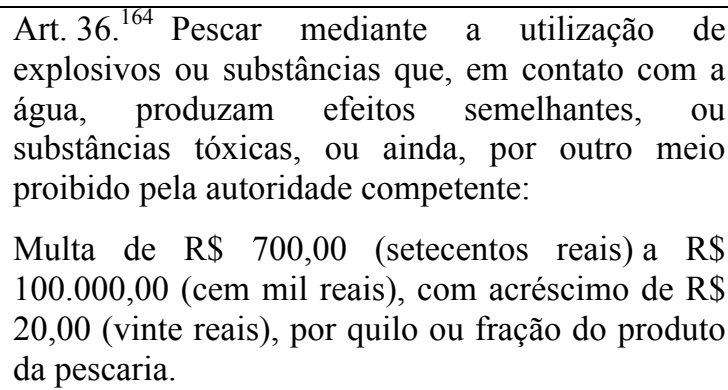 \\
\hline $\begin{array}{l}\text { Art. 36. Para os efeitos desta Lei, considera-se } \\
\text { pesca todo ato tendente a retirar, extrair, coletar, } \\
\text { apanhar, apreender ou capturar espécimes dos } \\
\text { grupos dos peixes, crustáceos, moluscos e vegetais } \\
\text { hidróbios, suscetíveis ou não de aproveitamento } \\
\text { econômico, ressalvadas as espécies ameaçadas de } \\
\text { extinção, constantes nas listas oficiais da fauna e } \\
\text { da flora. }\end{array}$ & $\begin{array}{l}\text { Art. } 42 .{ }^{165} \text { Para os efeitos deste Decreto, } \\
\text { considera-se pesca todo ato tendente a extrair, } \\
\text { retirar, coletar, apanhar, apreender ou capturar } \\
\text { espécimes dos grupos dos peixes, crustáceos, } \\
\text { moluscos aquáticos e vegetais hidróbios } \\
\text { suscetíveis ou não de aproveitamento econômico, } \\
\text { ressalvadas as espécies ameaçadas de extinção, } \\
\text { constantes nas listas oficiais da fauna e da flora. }\end{array}$ \\
\hline $\begin{array}{l}\text { Art. 38. Destruir ou danificar floresta considerada } \\
\text { de preservação permanente, mesmo que em } \\
\text { formação, ou utilizá-la com infringência das } \\
\text { normas de proteção: } \\
\text { Pena - detenção, de um a três anos, ou multa, ou } \\
\text { ambas as penas cumulativamente. }\end{array}$ & $\begin{array}{l}\text { Art. 43. Destruir ou danificar florestas-ou demais } \\
\text { formas de vegetação natural, em qualquer estágio } \\
\text { sucessional, ou utilizálas com infringência das } \\
\text { normas de proteção em área considerada de } \\
\text { preservação permanente, sem autorização do érgão } \\
\text { competente ou em desacordo com a obtida: } \\
\text { Art. } 43{ }^{166} \text { Destruir ou danificar florestas ou } \\
\text { demais formas de vegetação natural ou utilizá-las } \\
\text { com infringência das normas de proteção em área } \\
\text { considerada de preservação permanente, sem } \\
\text { autorização do órgão competente, quando exigível, } \\
\text { ou em desacordo com a obtida: } \\
\text { Multa de R\$ } 5.000,00 \text { (cinco mil reais) a R\$ }\end{array}$ \\
\hline
\end{tabular}

${ }^{163}$ Decreto n. 6.514, de 22 de julho de 2008.

${ }^{164}$ Decreto n. 6.514, de 22 de julho de 2008.

${ }^{165}$ Decreto n. 6.514, de 22 de julho de 2008.

${ }^{166}$ Decreto n. 6.514, de 22 de julho de 2008. 


\begin{tabular}{|c|c|}
\hline & $\begin{array}{l}50.000,00 \text { (cinqüenta mil reais), por hectare ou } \\
\text { fração. }\end{array}$ \\
\hline \multicolumn{2}{|l|}{$\begin{array}{l}\text { Parágrafo único. Se o crime for culposo, a pena } \\
\text { será reduzida à metade. }\end{array}$} \\
\hline $\begin{array}{l}\text { Art. 38-A. Destruir ou danificar vegetação } \\
\text { primária ou secundária, em estágio avançado ou } \\
\text { médio de regeneração, do Bioma Mata Atlântica, } \\
\text { ou utilizá-la com infringência das normas de } \\
\text { proteção: } \\
\text { Pena - detenção, de } 1 \text { (um) a } 3 \text { (três) anos, ou } \\
\text { multa, ou ambas as penas cumulativamente. }\end{array}$ & $\begin{array}{l}\text { Art. } 49 .{ }^{167} \text { Destruir ou danificar florestas ou } \\
\text { qualquer tipo de vegetação nativa, objeto de } \\
\text { especial preservação, não passíveis de autorização } \\
\text { para exploração ou supressão: } \\
\text { Multa de } \mathrm{R} \$ 6.000,00 \text { (seis mil reis) por hectare ou } \\
\text { fração. } \\
\text { Parágrafo único. A multa será acrescida de R\$ } \\
1.000,00 \text { (mil reais) por hectare ou fração quando a } \\
\text { situação prevista no caput se der em detrimento de } \\
\text { vegetação primária ou secundária no estágio } \\
\text { avançado ou médio de regeneração do bioma Mata } \\
\text { Atlântica. }\end{array}$ \\
\hline $\begin{array}{l}\text { Parágrafo único. Se o crime for culposo, a pena } \\
\text { será reduzida à metade }\end{array}$ & \\
\hline $\begin{array}{l}\text { Art. 39. Cortar árvores em floresta considerada de } \\
\text { preservação permanente, sem permissão da } \\
\text { autoridade competente: } \\
\text { Pena - detenção, de um a três anos, ou multa, ou } \\
\text { ambas as penas cumulativamente. }\end{array}$ & $\begin{array}{l}\text { Art. } 44{ }^{168} \text { Cortar árvores em área considerada de } \\
\text { preservação permanente ou cuja espécie seja } \\
\text { especialmente protegida, sem permissão da } \\
\text { autoridade competente: } \\
\text { Multa de } \mathrm{R} \$ 5.000,00 \text { (cinco mil reais) a R\$ } \\
20.000,00 \text { (vinte mil reais) por hectare ou fração, } \\
\text { ou } \mathrm{R} \$ 500,00 \text { (quinhentos reais) por árvore, metro } \\
\text { cúbico ou fração. }\end{array}$ \\
\hline $\begin{array}{l}\text { Art. 40. Causar dano direto ou indireto às } \\
\text { Unidades de Conservação e às áreas de que trata o } \\
\text { art. } 27 \text { do Decreto n }{ }^{\circ} 99.274 \text {, de } 6 \text { de junho de } \\
\text { 1990, independentemente de sua localização: } \\
\text { Pena - reclusão, de um a cinco anos. }\end{array}$ & $\begin{array}{l}\text { Art. 91. }{ }^{169} \text { Causar dano à unidade de conservação: } \\
\text { Multa de R\$ } 200,00 \text { (duzentos reais) a } \mathrm{R} \$ \\
100.000,00 \text { (cem mil reais). }\end{array}$ \\
\hline $\begin{array}{l}\S 3^{\circ} \text { Se o crime for culposo, a pena será reduzida à } \\
\text { metade. }\end{array}$ & \\
\hline $\begin{array}{l}\text { Art. 41. Provocar incêndio em mata ou floresta: } \\
\text { Pena - reclusão, de dois a quatro anos, e multa. }\end{array}$ & \\
\hline $\begin{array}{l}\text { Parágrafo único. Se o crime é culposo, a pena é de } \\
\text { detenção de seis meses a um ano, e multa. }\end{array}$ & \\
\hline $\begin{array}{l}\text { Art. 42. Fabricar, vender, transportar ou soltar } \\
\text { balões que possam provocar incêndios nas } \\
\text { florestas e demais formas de vegetação, em áreas } \\
\text { urbanas ou qualquer tipo de assentamento humano: } \\
\text { Pena - detenção de um a três anos ou multa, ou } \\
\text { ambas as penas cumulativamente. }\end{array}$ & $\begin{array}{l}\text { Art. 59. }{ }^{170} \text { Fabricar, vender, transportar ou soltar } \\
\text { balões que possam provocar incêndios nas } \\
\text { florestas e demais formas de vegetação, em áreas } \\
\text { urbanas ou qualquer tipo de assentamento humano: } \\
\text { Multa de R\$ } 1.000,00 \text { (mil reais) a R\$ } 10.000,00 \\
\text { (dez mil reais), por unidade. }\end{array}$ \\
\hline
\end{tabular}

${ }^{167}$ Decreto n. 6.514, de 22 de julho de 2008.

${ }^{168}$ Decreto n. 6.514, de 22 de julho de 2008.

${ }^{169}$ Decreto n. 6.514, de 22 de julho de 2008.

${ }^{170}$ Decreto n. 6.514, de 22 de julho de 2008. 


\begin{tabular}{|c|c|}
\hline $\begin{array}{l}\text { Art. 44. Extrair de florestas de domínio público ou } \\
\text { consideradas de preservação permanente, sem } \\
\text { prévia autorização, pedra, areia, cal ou qualquer } \\
\text { espécie de minerais: } \\
\text { Pena - detenção, de seis meses a um ano, e multa. }\end{array}$ & $\begin{array}{l}\text { Art. } 45 .{ }^{171} \text { Extrair de florestas de domínio público } \\
\text { ou áreas de preservação permanente, sem prévia } \\
\text { autorização, pedra, areia, cal ou qualquer espécie } \\
\text { de minerais: } \\
\text { Multa simples de } \mathrm{R} \$ 5.000,00 \text { (cinco mil reais) a } \\
\mathrm{R} \$ 50.000,00 \text { (cinqüenta mil reais) por hectare ou } \\
\text { fração. }\end{array}$ \\
\hline $\begin{array}{l}\text { Art. 45. Cortar ou transformar em carvão madeira } \\
\text { de lei, assim classificada por ato do Poder Público, } \\
\text { para fins industriais, energéticos ou para qualquer } \\
\text { outra exploração, econômica ou não, em desacordo } \\
\text { com as determinações legais: } \\
\text { Pena - reclusão, de um a dois anos, e multa. }\end{array}$ & $\begin{array}{l}\text { Art. 46. }{ }^{172} \text { Transformar madeira oriunda de } \\
\text { floresta ou demais formas de vegetação nativa em } \\
\text { carvão, para fins industriais, energéticos ou para } \\
\text { qualquer outra exploração, econômica ou não, sem } \\
\text { licença ou em desacordo com as determinações } \\
\text { legais: } \\
\text { Multa de R\$ 500,00 (quinhentos reais), por metro } \\
\text { cúbico de carvão-mdc. }\end{array}$ \\
\hline $\begin{array}{l}\text { Art. 46. Receber ou adquirir, para fins comerciais } \\
\text { ou industriais, madeira, lenha, carvão e outros } \\
\text { produtos de origem vegetal, sem exigir a exibição } \\
\text { de licença do vendedor, outorgada pela autoridade } \\
\text { competente, e sem munir-se da via que deverá } \\
\text { acompanhar o produto até final beneficiamento: } \\
\text { Pena - detenção, de seis meses a um ano, e multa. }\end{array}$ & $\begin{array}{l}\text { Art. } 47 .^{173} \text { Receber ou adquirir, para fins } \\
\text { comerciais ou industriais, madeira serrada ou em } \\
\text { tora, lenha, carvão ou outros produtos de origem } \\
\text { vegetal, sem exigir a exibição de licença do } \\
\text { vendedor, outorgada pela autoridade competente, e } \\
\text { sem munir-se da via que deverá acompanhar o } \\
\text { produto até final beneficiamento: } \\
\text { Multa de R\$ } 300,00 \text { (trezentos reais) por unidade, } \\
\text { estéreo, quilo, mdc ou metro cúbico aferido pelo } \\
\text { método geométrico. }\end{array}$ \\
\hline $\begin{array}{l}\text { Parágrafo único. Incorre nas mesmas penas quem } \\
\text { vende, expõe à venda, tem em depósito, transporta } \\
\text { ou guarda madeira, lenha, carvão e outros produtos } \\
\text { de origem vegetal, sem licença válida para todo o } \\
\text { tempo da viagem ou do armazenamento, outorgada } \\
\text { pela autoridade competente. }\end{array}$ & $\begin{array}{l}\S 1^{\text {o }} \text { Incorre nas mesmas multas quem vende, } \\
\text { expõe à venda, tem em depósito, transporta ou } \\
\text { guarda madeira, lenha, carvão ou outros produtos } \\
\text { de origem vegetal, sem licença válida para todo o } \\
\text { tempo da viagem ou do armazenamento, outorgada } \\
\text { pela autoridade competente ou em desacordo com } \\
\text { a obtida. }\end{array}$ \\
\hline $\begin{array}{l}\text { Art. 48. Impedir ou dificultar a regeneração natural } \\
\text { de florestas e demais formas de vegetação: } \\
\text { Pena - detenção, de seis meses a um ano, e multa. }\end{array}$ & 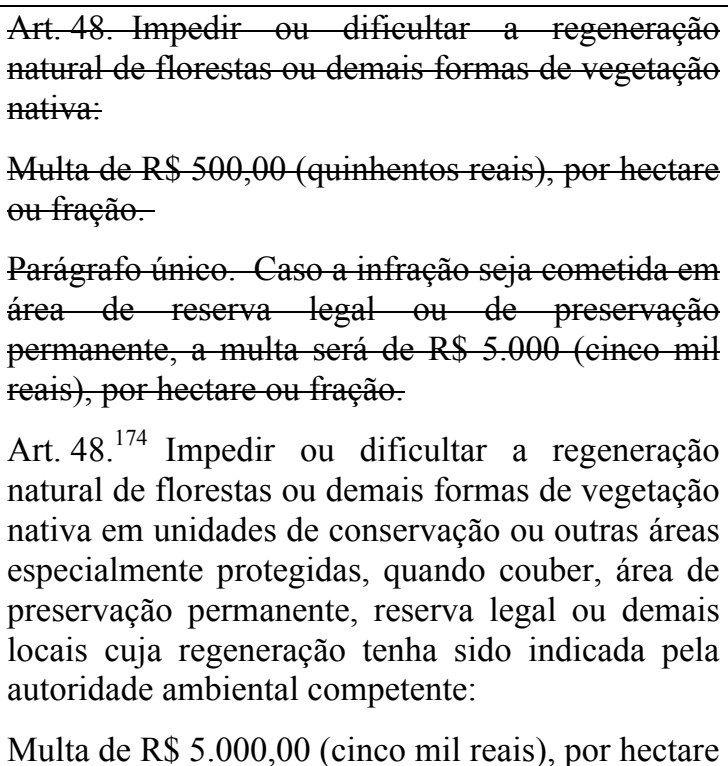 \\
\hline
\end{tabular}

${ }^{171}$ Decreto n. 6.514, de 22 de julho de 2008.

172 Decreto n. 6.514, de 22 de julho de 2008.

${ }^{173}$ Decreto n. 6.514, de 22 de julho de 2008.

${ }^{174}$ Decreto n. 6.514, de 22 de julho de 2008. 


\begin{tabular}{|c|c|}
\hline & ou fração. \\
\hline $\begin{array}{l}\text { Art. 49. Destruir, danificar, lesar ou maltratar, por } \\
\text { qualquer modo ou meio, plantas de ornamentação } \\
\text { de logradouros públicos ou em propriedade } \\
\text { privada alheia: } \\
\text { Pena - detenção, de três meses a um ano, ou multa, } \\
\text { ou ambas as penas cumulativamente. }\end{array}$ & $\begin{array}{l}\text { Art. 49. Destruir ou danificar florestas ou qualquer } \\
\text { tipo de vegetação nativa ou de espécies nativas } \\
\text { plantadas, objeto de especial preservação, não } \\
\text { passíveis de autorização para exploração ou } \\
\text { supressão: } \\
\text { Art. } 49 .{ }^{175} \text { Destruir ou danificar florestas ou } \\
\text { qualquer tipo de vegetação nativa, objeto de } \\
\text { especial preservação, não passíveis de autorização } \\
\text { para exploração ou supressão: } \\
\text { Multa de R } \$ 6.000,00 \text { (seis mil reis) por hectare ou } \\
\text { fração. }\end{array}$ \\
\hline $\begin{array}{l}\text { Parágrafo único. No crime culposo, a pena é de um } \\
\text { a seis meses, ou multa. }\end{array}$ & \\
\hline $\begin{array}{l}\text { Art. 50. Destruir ou danificar florestas nativas ou } \\
\text { plantadas ou vegetação fixadora de dunas, } \\
\text { protetora de mangues, objeto de especial } \\
\text { preservação: }\end{array}$ & $\begin{array}{l}\text { Art. } 49 .{ }^{176} \text { Destruir ou danificar florestas ou } \\
\text { qualquer tipo de vegetação nativa, objeto de } \\
\text { especial preservação, não passíveis de autorização } \\
\text { para exploração ou supressão: }\end{array}$ \\
\hline Pena - detenção, de três meses a um ano, e multa. & $\begin{array}{l}\text { Multa de R\$ 6.000,00 (seis mil reis) por hectare ou } \\
\text { fração. }\end{array}$ \\
\hline $\begin{array}{l}\text { Art. 50-A. Desmatar, explorar economicamente ou } \\
\text { degradar floresta, plantada ou nativa, em terras de } \\
\text { domínio público ou devolutas, sem autorização do } \\
\text { órgão competente: } \\
\text { Pena - reclusão de } 2 \text { (dois) a } 4 \text { (quatro) anos e } \\
\text { multa. }\end{array}$ & $\begin{array}{l}\text { Art. } 51 .{ }^{177} \text { Destruir, desmatar, danificar ou } \\
\text { explorar floresta ou qualquer tipo de vegetação } \\
\text { nativa ou de espécies nativas plantadas, em área de } \\
\text { reserva legal ou servidão florestal, de domínio } \\
\text { público ou privado, sem autorização prévia do } \\
\text { órgão ambiental competente ou em desacordo com } \\
\text { a concedida: } \\
\text { Multa de R\$ 5.000,00 (cinco mil reais) por hectare } \\
\text { ou fração. }\end{array}$ \\
\hline $\begin{array}{l}\text { Art. 51. Comercializar motosserra ou utilizá-la em } \\
\text { florestas e nas demais formas de vegetação, sem } \\
\text { licença ou registro da autoridade competente: } \\
\text { Pena - detenção, de três meses a um ano, e multa. }\end{array}$ & $\begin{array}{l}\text { Art. 57. }{ }^{178} \text { Comercializar, portar ou utilizar em } \\
\text { floresta ou demais formas de vegetação, } \\
\text { motosserra sem licença ou registro da autoridade } \\
\text { ambiental competente: } \\
\text { Multa de } \mathrm{R} \$ 1.000,00 \text { (mil reais), por unidade. }\end{array}$ \\
\hline $\begin{array}{l}\text { Art. 52. Penetrar em Unidades de Conservação } \\
\text { conduzindo substâncias ou instrumentos próprios } \\
\text { para caça ou para exploração de produtos ou } \\
\text { subprodutos florestais, sem licença da autoridade } \\
\text { competente: }\end{array}$ & $\begin{array}{l}\text { Art. } 92 .{ }^{179} \text { Penetrar em unidade de conservação } \\
\text { conduzindo substâncias ou instrumentos próprios } \\
\text { para caça, pesca ou para exploração de produtos ou } \\
\text { subprodutos florestais e minerais, sem licença da } \\
\text { autoridade competente, quando esta for exigível: }\end{array}$ \\
\hline Pena - detenção, de seis meses a um ano, e multa. & $\begin{array}{l}\text { Multa de } \mathrm{R} \$ 1.000,00 \text { (mil reais) a } \mathrm{R} \$ 10.000,00 \\
\text { (dez mil reais). }\end{array}$ \\
\hline $\begin{array}{l}\text { Art. 54. Causar poluição de qualquer natureza em } \\
\text { níveis tais que resultem ou possam resultar em } \\
\text { danos à saúde humana, ou que provoquem a } \\
\text { mortandade de animais ou a destrução }\end{array}$ & $\begin{array}{l}\text { Art. } 61 .{ }^{180} \text { Causar poluição de qualquer natureza } \\
\text { em níveis tais que resultem ou possam resultar em } \\
\text { danos à saúde humana, ou que provoquem a } \\
\text { mortandade de animais ou a destruição }\end{array}$ \\
\hline
\end{tabular}

${ }^{175}$ Decreto n. 6.514, de 22 de julho de 2008.

${ }^{176}$ Decreto n. 6.514, de 22 de julho de 2008.

${ }^{177}$ Decreto n. 6.514, de 22 de julho de 2008.

${ }^{178}$ Decreto n. 6.514, de 22 de julho de 2008.

${ }^{179}$ Decreto n. 6.514, de 22 de julho de 2008.

${ }^{180}$ Decreto n. 6.514, de 22 de julho de 2008. 
significativa da flora:
Pena - reclusão, de um a quatro anos, e multa.

$\S 1^{\circ}$ Se o crime é culposo:

Pena - detenção, de seis meses a um ano, e multa. $\S 2^{\circ}$ Se o crime:

I - tornar uma área, urbana ou rural, imprópria para a ocupação humana;

II - causar poluição atmosférica que provoque a retirada, ainda que momentânea, dos habitantes das áreas afetadas, ou que cause danos diretos à saúde da população;

III - causar poluição hídrica que torne necessária a interrupção do abastecimento público de água de uma comunidade;

IV - dificultar ou impedir o uso público das praias;

V - ocorrer por lançamento de resíduos sólidos, líquidos ou gasosos, ou detritos, óleos ou substâncias oleosas, em desacordo com as exigências estabelecidas em leis ou regulamentos:

Pena - reclusão, de um a cinco anos. significativa da biodiversidade:

Multa de R \$ 5.000,00 (cinco mil reais) a $\mathrm{R} \$$ $50.000 .000,00$ (cinqüenta milhões de reais).

Art. 62. ${ }^{181}$ Incorre nas mesmas multas do art. 61 quem:

I - tornar uma área, urbana ou rural, imprópria para ocupação humana;

H causar poluição atmosférica que provoque a retirada, ainda que momentânea, dos habitantes das áreas afetadas ou que provoque, de forma recorrente, significativo desconforto-respiratório ou-olfativo;

II - causar poluição atmosférica que provoque a retirada, ainda que momentânea, dos habitantes das áreas afetadas ou que provoque, de forma recorrente, significativo desconforto respiratório ou olfativo devidamente atestado pelo agente autuante;

III - causar poluição hídrica que torne necessária a interrupção do abastecimento público de água de uma comunidade;

IV - dificultar ou impedir o uso público das praias pelo lançamento de substâncias, efluentes, carreamento de materiais ou uso indevido dos recursos naturais;

V - lançar resíduos sólidos, líquidos ou gasosos ou detritos, óleos ou substâncias oleosas em desacordo com as exigências estabelecidas em leis ou atos normativos;

Art. 62. ${ }^{182}$ VII - deixar de adotar, quando assim o exigir a autoridade competente, medidas de precaução ou contenção em caso de risco ou de dano ambiental grave ou irreversível; e

Art. 63. ${ }^{183}$ Executar pesquisa, lavra ou extração de minerais sem a competente autorização, permissão, concessão ou licença da autoridade ambiental competente ou em desacordo com a obtida:

Multa de R\$ 1.500,00 (mil e quinhentos reais) a $\mathrm{R} \$ 3.000,00$ (três mil reais), por hectare ou fração.

Art. 63. ${ }^{184}$ Parágrafo único. Incorre nas mesmas multas quem deixa de recuperar a área pesquisada ou explorada, nos termos da autorização, permissão, licença, concessão ou determinação do órgão ambiental competente.

${ }^{181}$ Decreto n. 6.514, de 22 de julho de 2008.

${ }^{182}$ Decreto n. 6.514, de 22 de julho de 2008.

${ }^{183}$ Decreto n. 6.514, de 22 de julho de 2008.

${ }^{184}$ Decreto n. 6.514, de 22 de julho de 2008. 


\begin{tabular}{|c|c|}
\hline $\begin{array}{l}\text { Art. 56. Produzir, processar, embalar, importar, } \\
\text { exportar, comercializar, fornecer, transportar, } \\
\text { armazenar, guardar, ter em depósito ou usar } \\
\text { produto ou substância tóxica, perigosa ou nociva à } \\
\text { saúde humana ou ao meio ambiente, em desacordo } \\
\text { com as exigências estabelecidas em leis ou nos } \\
\text { seus regulamentos: }\end{array}$ & $\begin{array}{l}\text { Art. 64. }{ }^{185} \text { Produzir, processar, embalar, importar, } \\
\text { exportar, comercializar, fornecer, transportar, } \\
\text { armazenar, guardar, ter em depósito ou usar } \\
\text { produto ou substância tóxica, perigosa ou nociva à } \\
\text { saúde humana ou ao meio ambiente, em desacordo } \\
\text { com as exigências estabelecidas em leis ou em } \\
\text { seus regulamentos: }\end{array}$ \\
\hline Pena - reclusão, de um a quatro anos, e multa. & $\begin{array}{l}\text { Multa de } \mathrm{R} \$ 500,00 \text { (quinhentos reais) a } \mathrm{R} \$ \\
2.000 .000,00 \text { (dois milhões de reais). }\end{array}$ \\
\hline $\begin{array}{l}\S 1^{\circ} \text { Nas mesmas penas incorre quem: } \\
\text { I - abandona os produtos ou substâncias referidos } \\
\text { no caput ou os utiliza em desacordo com as } \\
\text { normas ambientais ou de segurança; } \\
\text { II - manipula, acondiciona, armazena, coleta, } \\
\text { transporta, reutiliza, recicla ou dá destinação final } \\
\text { a resíduos perigosos de forma diversa da } \\
\text { estabelecida em lei ou regulamento. } \\
\S 2^{\circ} \text { Se o produto ou a substância for nuclear ou } \\
\text { radioativa, a pena é aumentada de um sexto a um } \\
\text { terço. }\end{array}$ & $\begin{array}{l}\text { Art. } 64{ }^{186} \S 1^{\circ} \text { Incorre nas mesmas penas quem } \\
\text { abandona os produtos ou substâncias referidas no } \\
\text { caput, descarta de forma irregular ou os utiliza em } \\
\text { desacordo com as normas de segurança. } \\
\S 2^{\underline{o}} \text { Se o produto ou a substância for nuclear ou } \\
\text { radioativa, a multa é aumentada ao quíntuplo. }\end{array}$ \\
\hline $\begin{array}{l}\S 3^{\circ} \text { Se o crime é culposo: } \\
\text { Pena - detenção, de seis meses a um ano, e multa. }\end{array}$ & \\
\hline $\begin{array}{l}\text { Art. 60. Construir, reformar, ampliar, instalar ou } \\
\text { fazer funcionar, em qualquer parte do território } \\
\text { nacional, estabelecimentos, obras ou serviços } \\
\text { potencialmente poluidores, sem licença ou } \\
\text { autorização dos órgãos ambientais competentes, ou } \\
\text { contrariando as normas legais e regulamentares } \\
\text { pertinentes: }\end{array}$ & $\begin{array}{l}\text { Art. 66. Construir, reformar, ampliar, instalar ou } \\
\text { fazer funcionar estabelecimentes, obras ou } \\
\text { serviçes potencialmente poluideres ou utilizadores } \\
\text { de recursos naturais, sem licença ou autorização } \\
\text { des órgães ambientais competentes, em desacerde } \\
\text { eom a licença obtida ou-contrariando as normas } \\
\text { legais e regulamentos pertinentes: }\end{array}$ \\
\hline $\begin{array}{l}\text { Pena - detenção, de um a seis meses, ou multa, ou } \\
\text { ambas as penas cumulativamente. }\end{array}$ & $\begin{array}{l}\text { Art. } 66 .{ }^{187} \text { Construir, reformar, ampliar, instalar } \\
\text { ou fazer funcionar estabelecimentos, atividades, } \\
\text { obras ou serviços utilizadores de recursos } \\
\text { ambientais, considerados efetiva ou } \\
\text { potencialmente poluidores, sem licença ou } \\
\text { autorização dos órgãos ambientais competentes, } \\
\text { em desacordo com a licença obtida ou } \\
\text { contrariando as normas legais e regulamentos } \\
\text { pertinentes: } \\
\text { Multa de R\$ } 500,00 \text { (quinhentos reais) a R\$ }\end{array}$ \\
\hline
\end{tabular}

${ }^{185}$ Decreto n. 6.514, de 22 de julho de 2008.

${ }^{186}$ Decreto n. 6.514, de 22 de julho de 2008.

${ }^{187}$ Decreto n. 6.514, de 22 de julho de 2008. 


\begin{tabular}{|c|c|}
\hline & 10.000.000,00 (dez milhões de reais). \\
\hline $\begin{array}{l}\text { Art. 61. Disseminar doença ou praga ou espécies } \\
\text { que possam causar dano à agricultura, à pecuária, à } \\
\text { fauna, à flora ou aos ecossistemas: } \\
\text { Pena - reclusão, de um a quatro anos, e multa. }\end{array}$ & $\begin{array}{l}\text { Art. } 67 \text {. Disseminar doença ou praga ou espécies } \\
\text { que possam causar dano à agricultura, à pecuária, à } \\
\text { biodiversidade, à fauna, à flora ou aos } \\
\text { ecossistemas: } \\
\text { Art. } 67 .^{188} \text { Disseminar doença ou praga ou } \\
\text { espécies que possam causar dano à fauna, à flora } \\
\text { ou aos ecossistemas: } \\
\text { Multa de R\$ 5.000,00 (cinco mil reais) a R\$ } \\
5.000 .000,00 \text { (cinco milhões de reais). }\end{array}$ \\
\hline $\begin{array}{l}\text { Art. 62. Destruir, inutilizar ou deteriorar: } \\
\text { I - bem especialmente protegido por lei, ato } \\
\text { administrativo ou decisão judicial; } \\
\text { II - arquivo, registro, museu, biblioteca, } \\
\text { pinacoteca, instalação científica ou similar } \\
\text { protegido por lei, ato administrativo ou decisão } \\
\text { judicial: } \\
\text { Pena - reclusão, de um a três anos, e multa. }\end{array}$ & $\begin{array}{l}\text { Art. } 72 .{ }^{189} \text { Destruir, inutilizar ou deteriorar: } \\
\text { I - bem especialmente protegido por lei, ato } \\
\text { administrativo ou decisão judicial; ou } \\
\text { II - arquivo, registro, museu, biblioteca, } \\
\text { pinacoteca, instalação científica ou similar } \\
\text { protegido por lei, ato administrativo ou decisão } \\
\text { judicial: } \\
\text { Multa de } \mathrm{R} \$ 10.000,00 \text { (dez mil reais) a } \mathrm{R} \$ \\
500.000,00 \text { (quinhentos mil reais). }\end{array}$ \\
\hline $\begin{array}{l}\text { Parágrafo único. Se o crime for culposo, a pena é } \\
\text { de seis meses a um ano de detenção, sem prejuízo } \\
\text { da multa. }\end{array}$ & \\
\hline $\begin{array}{l}\text { Art. 63. Alterar o aspecto ou estrutura de } \\
\text { edificação ou local especialmente protegido por } \\
\text { lei, ato administrativo ou decisão judicial, em } \\
\text { razão de seu valor paisagístico, ecológico, } \\
\text { turístico, artístico, histórico, cultural, religioso, } \\
\text { arqueológico, etnográfico ou monumental, sem } \\
\text { autorização da autoridade competente ou em } \\
\text { desacordo com a concedida: } \\
\text { Pena - reclusão, de um a três anos, e multa. }\end{array}$ & $\begin{array}{l}\text { Art. } 73 .{ }^{190} \text { Alterar o aspecto ou estrutura de } \\
\text { edificação ou local especialmente protegido por } \\
\text { lei, ato administrativo ou decisão judicial, em } \\
\text { razão de seu valor paisagístico, ecológico, } \\
\text { turístico, artístico, histórico, cultural, religioso, } \\
\text { arqueológico, etnográfico ou monumental, sem } \\
\text { autorização da autoridade competente ou em } \\
\text { desacordo com a concedida: } \\
\begin{array}{l}\text { Multa de R\$ } 10.000,00 \text { (dez mil reais) a R\$ } \\
200.000,00 \text { (duzentos mil reais). }\end{array}\end{array}$ \\
\hline $\begin{array}{l}\text { Art. 64. Promover construção em solo não } \\
\text { edificável, ou no seu entorno, assim considerado } \\
\text { em razão de seu valor paisagístico, ecológico, } \\
\text { artístico, turístico, histórico, cultural, religioso, } \\
\text { arqueológico, etnográfico ou monumental, sem } \\
\text { autorização da autoridade competente ou em } \\
\text { desacordo com a concedida: } \\
\text { Pena - detenção, de seis meses a um ano, e multa. }\end{array}$ & $\begin{array}{l}\text { Art. } 74{ }^{191} \text { Promover construção em solo não } \\
\text { edificável, ou no seu entorno, assim considerado } \\
\text { em razão de seu valor paisagístico, ecológico, } \\
\text { artístico, turístico, histórico, cultural, religioso, } \\
\text { arqueológico, etnográfico ou monumental, sem } \\
\text { autorização da autoridade competente ou em } \\
\text { desacordo com a concedida: } \\
\begin{array}{l}\text { Multa de R } \$ 10.000,00 \text { (dez mil reais) a R\$ } \\
100.000,00 \text { (cem mil reais). }\end{array}\end{array}$ \\
\hline
\end{tabular}

${ }^{188}$ Decreto n. 6.514, de 22 de julho de 2008.

${ }^{189}$ Decreto n. 6.514, de 22 de julho de 2008.

${ }^{190}$ Decreto n. 6.514, de 22 de julho de 2008.

${ }^{191}$ Decreto n. 6.514, de 22 de julho de 2008. 


\begin{tabular}{|c|c|}
\hline $\begin{array}{l}\text { Art. 65. Pichar, grafitar ou por outro meio } \\
\text { conspurcar edificação ou monumento urbano: } \\
\text { Pena - detenção, de três meses a um ano, e multa. } \\
\text { Parágrafo único. Se o ato for realizado em } \\
\text { monumento ou coisa tombada em virtude do seu } \\
\text { valor artístico, arqueológico ou histórico, a pena é } \\
\text { de seis meses a um ano de detenção, e multa. }\end{array}$ & $\begin{array}{l}\text { Art. } 75 .{ }^{192} \text { Pichar, grafitar ou por outro meio } \\
\text { conspurcar edificação alheia ou monumento } \\
\text { urbano: } \\
\text { Multa de R\$ } 1.000,00 \text { (mil reais) a R\$ } 50.000,00 \\
\text { (cinqüenta mil reais). } \\
\text { Parágrafo único. Se o ato for realizado em } \\
\text { monumento ou coisa tombada, a multa é aplicada } \\
\text { em dobro. }\end{array}$ \\
\hline $\begin{array}{l}\text { Art. 66. Fazer o funcionário público afirmação } \\
\text { falsa ou enganosa, omitir a verdade, sonegar } \\
\text { informações ou dados técnico-científicos em } \\
\text { procedimentos de autorização ou de licenciamento } \\
\text { ambiental: } \\
\text { Pena - reclusão, de um a três anos, e multa. }\end{array}$ & \\
\hline $\begin{array}{l}\text { Art. 67. Conceder o funcionário público licença, } \\
\text { autorização ou permissão em desacordo com as } \\
\text { normas ambientais, para as atividades, obras ou } \\
\text { serviços cuja realização depende de ato } \\
\text { autorizativo do Poder Público: } \\
\text { Pena - detenção, de um a três anos, e multa. }\end{array}$ & \\
\hline $\begin{array}{l}\text { Parágrafo único. Se o crime é culposo, a pena é de } \\
\text { três meses a um ano de detenção, sem prejuízo da } \\
\text { multa. }\end{array}$ & \\
\hline $\begin{array}{l}\text { Art. 68. Deixar, aquele que tiver o dever legal ou } \\
\text { contratual de fazê-lo, de cumprir obrigação de } \\
\text { relevante interesse ambiental: } \\
\text { Pena - detenção, de um a três anos, e multa. }\end{array}$ & \\
\hline $\begin{array}{l}\text { Parágrafo único. Se o crime é culposo, a pena é de } \\
\text { três meses a um ano, sem prejuízo da multa }\end{array}$ & \\
\hline $\begin{array}{l}\text { Art. 69. Obstar ou dificultar a ação fiscalizadora } \\
\text { do Poder Público no trato de questões ambientais: } \\
\text { Pena - detenção, de um a três anos, e multa. }\end{array}$ & \\
\hline $\begin{array}{l}\text { Art. 69-A. Elaborar ou apresentar, no } \\
\text { licenciamento, concessão florestal ou qualquer } \\
\text { outro procedimento administrativo, estudo, laudo } \\
\text { ou relatório ambiental total ou parcialmente falso } \\
\text { ou enganoso, inclusive por omissão: } \\
\text { Pena - reclusão, de } 3 \text { (três) a } 6 \text { (seis) anos, e multa. }\end{array}$ & \\
\hline $\begin{array}{l}\S 1^{\circ} \text { Se o crime é culposo: } \\
\text { Pena - detenção, de } 1 \text { (um) a } 3 \text { (três) anos. } \\
\S 2^{\circ} \text { A pena é aumentada de } 1 / 3 \text { (um terço) a } 2 / 3 \\
\text { (dois terços), se há dano significativo ao meio } \\
\text { ambiente, em decorrência do uso da informação } \\
\text { falsa, incompleta ou enganosa. }\end{array}$ & \\
\hline
\end{tabular}

Elaboração própria

Constata-se que o legislador, com exceção dos crimes relacionados ao funcionalismo público, apenas transpôs, de um âmbito para o outro, infrações

${ }^{192}$ Decreto n. 6.514, de 22 de julho de 2008. 
anteriormente existentes, sem atentar para suas peculiaridades e princípios do Direito Penal, principalmente os relativos à intervenção mínima (Direito Penal como ultima ratio).

Pior: a Lei de Crimes Ambientais pouco inovou na questão da tutela penal, deixando inclusive de estabelecer uma diferenciação entre as infrações administrativas e penais. Verifica-se que na esfera administrativa em muitos casos existe exatamente a mesma tutela prevista na seara criminal, assim como as mesmas formas de punição, como será exposto a seguir.

Constata o professor MIGUEL REALE JÚNIOR que "esta administrativização do Direito Penal torna a lei penal um regramento, sancionando a inobservância a regras de conveniência da Administração Pública, matérias antes de cunho disciplinar, revelando-se que a lei penal visa antes a organizar do que proteger, destituída, portanto, da finalidade de consagrar valores e tutelá-los" (2002, p. 21).

A indevida organização administrativa deve ser solucionada com reestruturação e fiscalização para haver eficácia dos instrumentos administrativos e civis. Recorrer a soluções radicais penais é disseminar excessiva intimidação estatal e ignorar soluções reais para o problema, podendo até mesmo infectar o Direito Penal com o germe da inoperância e consequente descrédito.

Ressalte-se que o princípio da intervenção mínima do Direito Penal não preza pelo aniquilamento deste ramo do direito, diferentemente da concepção de abolicionismo penal. O pensamento do minimalismo penal (BIANCHINI, 2002, p. 26) restringe a atuação do sistema repressivo criminal aos casos em que este se mostrar indispensável.

Mas os doutrinadores contrários à tutela penal ambiental, ou ao menos à apresentada em nosso ordenamento jurídico, evocam, acertadamente, as possibilidades múltiplas e flexíveis de instrumentos das esferas civil e administrativa. O raciocínio do Direito Penal mínimo coaduna-se com a percepção de que a Lei dos Crimes Ambientais tipifica como delito "no mais das vezes, ações e omissões que constituem, antes desatenção aos interesses da Administração, desobediência a esses interesses, do que atos efetivamente lesivos ao bem jurídico fundamental que se visa tutelar e justificadamente dignos de proteção penal" (REALE JÚNIOR, 1999a, p. 121). Com tal posicionamento, o legislativo promove a vulgarização do Direito Penal, com a diminuição da proteção dos bens jurídicos fundamentais contra os atos lesivos mais gritantes para a construção de uma "ilusão penal" (REALE JÚNIOR, 1999a, p. 121), em que, no campo dos interesses difusos, condutas 
irrelevantes ou meramente de desobediência administrativa carregam o manto da guarida penal.

Com essa inflação legislativa penal, ${ }^{193}$ abandona-se o caráter instrumental de proteção dos bens jurídicos, adquirindo a esfera penal um jaez simbólico, demasiadamente intervencionista e preventivo, cuja lógica reside na exasperação das penas. A "sede de punir" vocalizada de maneira precipitada na esfera pública e, em especial, na atividade legislativa, transforma o sistema penal, tradicionalmente identificado pela condição de ultima ratio, em instrumento de prima ratio ou "tábua de salvação de todas as aflições" (REALE JÚNIOR, 1999a, p. 121).

Em outros termos, acentua-se o "aumento das cominações penais, bem como as tendências que levam a uma difusão do injusto (que no Direito Penal ambiental, por exemplo, através do princípio da acessoriedade administrativa, somente as autoridades administrativas estipulam onde começa o limiar do injusto criminal). Tudo isso leva, finalmente, a uma perda dos tradicionais pressupostos de imputação, os quais o Direito Penal não poderia deixar passar, de modo algum, sem prejuízos" (HASSEMER, 2003, p. 153).

A aplicação do princípio da intervenção mínima traria resultados diversos dos observados no ordenamento brasileiro. Revelar-se-ia como alternativa, em alguns casos, a abstenção do uso do Direito Penal, quando o bem jurídico não possui relevância penal ou caso a intervenção seja excessivamente desproporcional à infração cometida. A análise prévia das demais formas de proteção sócio-estatais asseguraria a utilização da ameaça penal em termos de último recurso. O sistema punitivo, assim, intercederia na inexistência de outros controles eficazes aos bens jurídicos mais valiosos, dos ataques mais intoleráveis, atuando somente de forma subsidiária.

A Lei n. 9.605/98, com ausência de técnica, tipificou atividades de mera conduta, sem potencialidade real de dano e com descrições abertas, que contrariam o princípio da legalidade. Isso trouxe à esfera penal o resguardo de ações infratoras de meros regulamentos ou determinações administrativas, como praticar abuso ou maus-tratos a animais domésticos, pescar espécimes com tamanhos inferiores aos permitidos, abater animal sem autorização competente, transportar balões que possam provocar incêndios nas florestas, danificar planta de ornamentação em propriedade privada alheia, penetrar em

193 DOTTI (2001, p. 36) destaca que a inflação legislativa traz "duas perspectivas bem definidas: a massificação da responsabilidade criminal e a erosão do sistema positivo. Ambos esses aspectos são demonstrativos da ausência de uma Política Criminal definida em nível de Governo". 
Unidade de Conservação conduzindo substâncias ou instrumentos próprios para caça, armazenar substância tóxica perigosa ou nociva à saúde humana, pichar edificação ou monumento urbano.

Vê-se que a ausência de autorizações e o não seguimento das condutas determinadas administrativamente são facilmente coibidos pelas esferas civil e administrativa, ou até mesmo pela mera reprovabilidade moral. Ressalte-se, ainda, que a ordem jurídico-administrativa encontra-se melhor equipada para responder à prevenção do domínio ambiental, tanto pela proximidade dos agentes poluidores carentes de licenças ambientais, como pela facilidade, rapidez e mobilidade na fiscalização e na criação de novos instrumentos normativos, como regulamentos e portarias, adequados à dinâmica das atividades econômicas potencialmente lesivas ao meio ambiente. ${ }^{194}$

As condutas ambientais previstas no ordenamento brasileiro retiram a autoridade solene da qual o Direito Penal deveria se revestir; "a defesa imprescindível do meio ambiente não autoriza que se elabore e o Congresso aprove lei penal ditatorial, seja por transformar comportamentos irrelevantes em crime, alçando, por exemplo, à condição de delito o dano culposo, seja fazendo descrição inintelegível de condutas, seja considerando crimes infrações nitidamente de caráter apenas administrativo, seja fazendo tábula rasa do princípio da legalidade ao dizer genericamente o que vem a ser infração administrativa." (REALE JÚNIOR, 1999a, p. 127).

Nessa linha, advoga-se que ao legislador cumpre a função de determinar o limite do Direito Administrativo, ${ }^{195}$ para então estabelecer os ilícitos penais, com alicerce em dois pilares básicos: o grau de lesividade da conduta (desvalor ético-social) e a ordem políticocriminal (rapidez, eficácia da sanção, fragmentariedade e subsidiariedade). ${ }^{196}$

\footnotetext{
${ }^{194} \mathrm{Na}$ comparação entre as esferas, nota-se que "o direito administrativo é o campo por excelência do móbil e do alterável, enquanto que o direito penal deve ser, tanto quanto possível, o domínio do que permanece e tem tendência para o imodificável" (RODRIGUES, 1996, p. 14-24).

${ }^{195}$ FERRARI expressou-se no sentido de fortalecer um Direito Administrativo Sancionador, "devendo o juiz, inicialmente, afixar-se na questão administrativa, para apenas, posteriormente, legitimar-se sobre eventual incidência penal, cabendo primeiro esgotar-se todos os meios e estruturas sancionatórias-administrativas, para só a partir de então, concluir-se, sem dubiedade, acerca da fundamentação, objetivos e necessidade de interferência penal, hoje incerta." (2003, p. 1198).

${ }^{196}$ Essas conclusões convergem com o posicionamento de EDIS MILARÉ, que afirma que o progresso da lei foi muito mais político do que técnico-jurídico, permanecendo a tarefa aos legisladores de aprimorar meios de proteção eficazes para defender as futuras gerações (2004, p. 804).
} 


\section{SANÇÕES APLICÁVEIS AOS CRIMES AMBIENTAIS}

Como analisado no capítulo anterior, diante do desprezo ao princípio da intervenção mínima e à intervenção subsidiária do Direito Penal, observa-se acentuada similaridade entre os preceitos primários das normas penais ambientais - dispostos na Lei n. $9.605 / 98$ - e as infrações administrativas de proteção do meio ambiente brasileiro. Ainda, verifica-se uma proximidade entre as sanções aplicadas nos âmbitos penal e administrativo (com a inequívoca exceção da pena privativa de liberdade) no que se refere às lesões ou à colocação em risco do bem jurídico ambiental.

Este capítulo tem como propósito analisar as semelhanças e diferenças existentes entre as sanções aplicáveis às pessoas físicas e às pessoas jurídicas pelo cometimento de um injusto penal, em comparação com as punições previstas no âmbito civil e administrativo. Busca-se, em suma, averiguar se as sanções da legislação penal ambiental são adequadas para a prevenção e a repressão dos atos atentatórios ao meio ambiente. Para tanto, mostra-se relevante a consideração dos recursos processuais adotados na sistemática brasileira para a solução célere dos conflitos de menor potencial ofensivo, visto que as consequências do delito (pena) ganharam novos contornos na temática do Direito Penal ambiental com as reformas processuais das décadas de 1990 e 2000.

\section{V.1. Sanções penais aplicáveis às pessoas físicas}

\section{A) Penas privativas de liberdade}

Afastando as hipóteses das vedadas penas corporais, as sanções genuinamente aplicadas às pessoas físicas, em caso de condenação por crimes no Direito Penal brasileiro, são as penas privativas de liberdade. ${ }^{197}$ Contudo, a eleição da sanção ou sanções mais

\footnotetext{
197 No Direito Penal brasileiro, ainda encontramos primordialmente a previsão das penas privativas de liberdade, conforme indica levantamento realizado por $M A C H A D O$ (2009, p. 93): "Focalizando a norma de sanção prevista nos tipos penais em vigor, $92 \%$ são penas de prisão (50\% de reclusão e $42 \%$ de detenção). Pouco mais da metade dessas penas está cumulada com a pena de multa. Autonomamente, a pena de multa aparece em menos de 4\% dos tipos penais do ordenamento jurídico brasileiro. Esse quadro é suficiente para indicar que a prisão é a sanção de referência do sistema e que a multa ocupa um lugar absolutamente
} 
adequadas para o âmbito da criminalidade econômica (em que se insere o Direito Penal ambiental) não encontra resposta peremptória na pena de prisão. ${ }^{198}$

Nos últimos anos, o descrédito existente em relação à pena privativa de liberdade ${ }^{199}$ e a sua capacidade de reeducação e de reinserção social (REALE JÚNIOR ET ALLI, 1985, p. 129) também produziu reflexos sobre a legislação criminal econômica. ${ }^{200}$ Por se considerar que o infrator econômico não necessita de ressocialização carcerária, as penas de detenção ou de reclusão passaram a ser consideradas inidôneas aos autores de crimes de colarinho branco. $^{201}$

Por outro lado, ROSARIO DE VICENTE MARTÍNEZ (2008: 192) destaca que, em matéria de crimes contra a ordem sócio-econômica, a previsão de penas privativas de liberdade exerce um papel fundamental para a prevenção geral, porque a pena de prisão gera um efeito de intimidação ainda mais significativo às classes média e alta. Para esse setor da sociedade, a detenção e a reclusão, em conjunto com a publicidade negativa que as acompanha, representam as mais terríveis e temíveis consequências jurídicas aplicáveis (TIEDEMANN, 1985, p. 161).

Questiona-se o fim preventivo geral exercido pela norma penal ambiental que prevê em seu preceito secundário a pena privativa de liberdade. Apesar de intimidar, em curto prazo, por meio de seu caráter comunicativo, as penas de detenção e reclusão não são aplicadas no caso concreto pelos tribunais, ${ }^{202}$ desencadeando, em longo prazo, descrédito da intimidação jurídico-penal. Nesse caso, a previsão legal não cumpre seu papel instrumental, tão-somente apresenta-se como uma ilusão simbólica de proteção penal.

Não se pode negar que essa intimidação inicial da norma penal colabora para a criação de uma consciência e censura moral em relação à destruição do meio ambiente. Contudo, esse resultado provém de mecanismos ilusórios e arbitrários, em que se privilegia

marginal nas penas definidas pelo legislador". Sobre o SISPENAS: Sistema de Consulta sobre Crimes, Penas e Alternativas à Prisão, que constitui um banco de dados dos crimes previstos na legislação penal brasileira, suas respectivas penas e as alternativas à pena de prisão existentes, ver SÉRIE PENSANDO O DIREITO (2009b).

${ }^{198}$ Algumas considerações sobre o fundamento, o sentido e a aplicação das penas no âmbito da criminalidade econômica geram dúvidas sobre se a pena privativa de liberdade é adequada para a obtenção dos fins propostos. Ver TIEDEMANN (1985).

${ }_{199}$ Cf. BITENCOURT (2001).

${ }^{200}$ Cf. JORGE FIQUEIREDO DIAS, há um movimento de autonomização do Direito Penal econômico, que deve se impor em três níveis: a. especificidade do ilícito; b. especificidade das sanções, seus fundamentos, seu sentido e seus limites; c. especificidade da aplicação concreta das sanções, ao nível processual (2006, p. 60).

${ }^{201}$ IVETTE SENISE FERREIRA (1997) reconhece a impropriedade de uma pena de prisão para a recuperação social do condenado em crimes ambientais, configurando-se sanção inútil ou desnecessária, em face das características criminológicas do autor da infração ambiental. Acredita a autora haver mais vantagens na aplicação de penas alternativas nesses casos.

${ }^{202}$ Ver levantamento jurisprudencial apresentado no capítulo 6. 
a intimidação abstrata da norma, a ameaça de início de um processo penal, sua respectiva publicidade e, principalmente, uma possível prisão processual, em lugar de se sustentar na pena efetivamente cominada com trânsito em julgado. Os meios, portanto, parecem ser mais relevantes que os fins.

Mesmo para VICENTE MARTÍNEZ (2008), que afirma a necessidade e idoneidade da pena privativa de liberdade aos crimes econômicos, a pena curta de prisão (inferior a seis meses de encarceramento) não se justifica em termos de prevenção especial. A autora, além de constatar elevados índices de reincidência na realidade espanhola, entende que essas sanções não são capazes de exercer uma influência positiva de ressocialização sobre o condenado.

No Brasil, raramente se aplicam penas curtas de prisão, diante dos diferentes regimes de cumprimento da pena privativa de liberdade (artigos 34 a 36 do Código Penal) e das hipóteses de substituição (artigos 43 a 52 do Código Penal). ${ }^{203}$ O efeito "short-sharpshock" de intimidação é verificado apenas no âmbito processual - com as prisões temporárias, provisórias e preventivas -, em que o acusado, privado de sua liberdade em caráter precário, durante o curso do processo, sente a "ameaça da pena". Dessa forma, o procedimento penal acarreta mais intimidação do que a própria pena (principalmente ao se considerar que são poucos os casos que efetivamente terminam com condenações transitadas em julgado, no âmbito penal ambiental). ${ }^{204}$

Em análise do conceito material de delito, SALVADOR NETTO avalia a aplicação da pena privativa de liberdade considerando a finalidade do Estado democrático, a justificativa no merecimento da pena e sua necessidade. $\mathrm{O}$ encarceramento, ora com o discurso de ressocialização, ora com o de segregação dos sujeitos perigosos para a sociedade, é retratado como medida ineficaz para o controle da criminalidade no Estado democrático, principalmente pelas péssimas condições dos estabelecimentos prisionais e por sua incapacidade de proteger bens jurídicos. Sob as perspectivas de prevenção especial e geral, a utilização da privação de liberdade, como medida extrema, deve diminuir tanto no âmbito judicial quanto no legislativo, como ameaça genérica, ex ante, à infração do

\footnotetext{
${ }^{203}$ Em estudo realizado sobre as penas alternativas, houve a indicação de oito benefícios: "(i) Composição civil dos danos; (ii) Transação penal; (iii) Suspensão condicional do processo; (iv) Substituição da pena privativa de liberdade por pena restritiva de direitos e/ou por pena de multa; (v) Suspensão condicional da pena por 2 a 4 anos; (vi) Suspensão condicional da pena por 4 a 6 anos; (vii) Limite de cumprimento de pena (30 anos); (viii) Livramento condicional (com tempo de cumprimento mínimo de 1/3, ou 2/3)." (SÉRIE PENSANDO O DIREITO, 2009b, p. 18).

${ }^{204}$ Esse foi o resultado da pesquisa realizada nos tribunais superiores brasileiros, conforme será exposto no próximo capítulo.
} 
dever (2009b, p. 316), especialmente para as condutas que "não possuem altissonância" (2009b, p. 317) para a imposição de tal encargo e para os delitos de massa, como os delitos ambientais.

No posicionamento de SILVA SÁNCHEZ (2008b: 178), como o expansionismo penal desencadeou um afrouxamento das garantias político-criminais e uma flexibilização dos critérios de imputação no Direito Penal de segunda velocidade, a força comunicativa da sanção não pode basear-se na imposição de penas privativas de liberdade, devendo-se acionar outros mecanismos, como as sanções pecuniárias e as restritivas de direitos.

\section{B) Penas restritivas de direitos}

Com a crítica ao encarceramento ${ }^{205}$ dos infratores de normas penais econômicas, ganharam destaque as penas alternativas à prisão. Apesar de os delitos penais ambientais da Lei n. 9.605/98 trazerem, em cada tipo penal, a previsão de pena privativa de liberdade e multa, a parte geral da referida lei admite a substituição por penas restritiva de direitos, reproduzindo a lógica do Código Penal:

Art. $7^{\circ}$ As penas restritivas de direitos são autônomas e substituem as privativas de liberdade quando:

I - tratar-se de crime culposo ou for aplicada a pena privativa de liberdade inferior a quatro anos;

II - a culpabilidade, os antecedentes, a conduta social e a personalidade do condenado, bem como os motivos e as circunstâncias do crime indicarem que a substituição seja suficiente para efeitos de reprovação e prevenção do crime.

Parágrafo único. As penas restritivas de direitos a que se refere este artigo terão a mesma duração da pena privativa de liberdade substituída.

Art. $8^{\circ}$ As penas restritivas de direito são:

I - prestação de serviços à comunidade;

II - interdição temporária de direitos;

III - suspensão parcial ou total de atividades;

IV - prestação pecuniária;

$\mathrm{V}$ - recolhimento domiciliar.

O Código Penal, em seus artigos 43 e 44, já previa a possibilidade substituição da pena de prisão - em crime culposo ou doloso com sanção fixada abaixo de 4 anos - por

\footnotetext{
205 O movimento humanitário do Direito Penal apresenta-se, no âmbito internacional, com a Declaração Universal de Direitos Humanos (1948), o Pacto Internacional de Direitos Civis e Políticos (1966) e as Regras de Tóquio (Resolução 45/110 da ONU, Assembléia Geral realizada em 14 de dezembro de 1990).
} 
penas restritivas de direitos, se estas restassem suficientes para a reprovação e a prevenção do crime.

Na mesma linha do Código Penal, a Lei de Crimes Ambientais manteve as características da autonomia e da substitutividade das penas restritivas de direito, inadmitindo a cumulação da privativa de liberdade com as sanções alternativas no mesmo processo. Se há substituição da prisão por restritivas de direitos, estas terão a mesma duração que a primeira pena cominada.

Ressaltam-se, entretanto, algumas particularidades já mencionadas. ${ }^{206}$ A Lei n. 9.605/98, entre as limitações para a substituição, não mencionou a "violência" e a "grave ameaça" - elementos que impedem as restritivas de direitos no Código Penal. Frente a essa conjuntura, PASCOLATTI JÚNIOR (2009, p. 54) afirma que, mesmo que praticado um delito ambiental com violência ou grave ameaça à pessoa, é possível a permuta da pena privativa de liberdade por restritiva de direitos, visto que não se admite no Direito Penal a analogia in malan partem, prevalecendo pois a especialidade da lei em detrimento da regra geral do CP. Acrescenta-se que a Lei de Crimes Ambientais também foi omissa quanto à vedação prevista no artigo 44, II do Código Penal em relação ao reincidente doloso. Por essa razão, mantém-se o mesmo entendimento acima esboçado.

Não se pretende no presente trabalho descrever cada uma das sanções penais alternativas previstas na lei. ${ }^{207}$ Destaca-se, entretanto, que somente a prestação de serviços à comunidade apresenta especificidade em relação à questão ambiental, uma vez que as tarefas devem ser realizadas “junto a parques e jardins públicos e unidades de conservação, e, no caso de dano da coisa particular, pública ou tombada, na restauração desta, se possível", conforme redação do art. $9^{\circ}$ da Lei 9.605/98.

Note-se que a legislação não pareceu muito engenhosa na previsão de penas restritivas de direitos, restando ao julgador, no caso concreto, aplicar sanções diversificadas e relacionadas à temática ambiental. ${ }^{208}$

Como se averiguará na pesquisa jurisprudencial realizada (capítulo 6), nos processos sobre crimes ambientais que alcançam os tribunais superiores, a incidência de

\footnotetext{
${ }^{206}$ Item III.5.

${ }^{207}$ Cf. PRADO (2005, p. 186-220) e PASCOLATTI JÚNIOR (2009, p. 51-85).

${ }^{208}$ Trataremos dessa questão no capítulo 6 , em análise aos julgados dos tribunais superiores.
} 
condenações com penas privativas de liberdade é irrisória. ${ }^{209} \mathrm{Em}$ regra, os casos são resolvidos com aplicação de penas restritivas de direitos, seguindo a determinação do art. $7^{\circ}$ da Lei n. 9.605/98.

Não restando outra alternativa a não ser reconhecer a vigência dos tipos penais ambientais no ordenamento jurídico brasileiro, somente a aplicação de sanções penais não privativas de liberdade, dentro de um parâmetro de razoabilidade e proporcionalidade, justificaria a intervenção do poder estatal nesta seara. ${ }^{210}$

\section{V.2. Sanções penais aplicáveis às pessoas jurídicas}

O moderno Direito Penal depara-se, em matéria de meio ambiente e delitos econômicos, com o desafio de enfrentar os graves fatos lesivos ocorridos pela utilização de estruturas empresariais. Já amplamente discutida na doutrina, ${ }^{211}$ a responsabilidade penal das pessoas jurídicas quebra a lógica tradicional das estruturas típicas de imputação. ${ }^{212}$

Não obstante o prolífico debate sobre a forma de imputação de responsabilidades na complexa estrutura empresarial hierárquica, ${ }^{213}$ este tópico aborda somente as possíveis sanções jurídicas aplicáveis às empresas na Lei n. 9.605/98.

\footnotetext{
209 Constatou-se apenas uma condenação em regime fechado em 150 acórdãos sobre a Lei 9.605/98 analisados, sendo 58 no STF e 92 no STJ.

${ }^{210}$ Assim expõe SILVA SÁNCHEZ: "puede admitirse resignadamente la expansión - ya producida - del Derecho penal a ilícitos de acumulación o peligro presunto, esto es, a conductas alejadas de la creación de un peligro real para bienes individuales (e incluso supraindividuales, si es que éstos se conciben con un mínimo rigor). Pero la admisión de la razonabilidad de esta segunda expansión, que viene acompañada de los rasgos de flexibilización reiteradamente aludidos, exigiría ineludiblemente que los referidos ilícitos no recibieran penas de prisión. En la medida en que esta exigencia no es respetada por los ordenamientos jurídicos de nuestro entorno, por el momento, la expansión del Derecho penal carece, en mi opinión, de la requerida razonabilidad político-jurídica" (SILVA SÁNCHEZ, 2008b, p. 182).

${ }^{211}$ Cf. FEIJOO SÁNCHEZ (2002) e PRADO (2001).

${ }^{212}$ Resume GUARDIOLA LAGO esta alteração da lógica penal, diante da "imposibilidad de afirmar la capacidad de acción, la capacidad de culpabilidad y la posibilidad de sufrir penas de estos entes colectivos, puesto que todos estos obstáculos conducen a un discurso circular. Al basarse en categorías dogmáticas ideadas exclusivamente en torno a la consideración de la persona física como único sujeto activo posible, se sigue la imposibilidad de incluir en estos conceptos previamente establecidos a la persona jurídica" (GUARDIOLA LAGO, 2004, p. 109).

${ }^{213}$ Há autores que negam a possibilidade de responsabilidade penal da pessoa jurídica (princípio societas delinquere non potest), por não admitirem uma versão de responsabilidade penal objetiva ao ente criado por ficção jurídica, dissociando-se da culpabilidade. Outros a defendem sob o enfoque de ser a pessoa jurídica ente de existência real, imputável no plano pragmático-sociológico, em decorrência de ação delituosa institucional paralela às ações humanas individuais (SHECAIRA, 2003).
} 
Antes de adentrar o tema, cabe adotar como pressuposto que os entes coletivos não podem ser condenados às penas privativas de liberdade. Afinal, a pena de prisão, imposta somente aos indivíduos, figuraria completamente incongruente e ineficaz para sancionar entidades abstratas.

A Lei dos Crimes Ambientais, nos artigos 21 a 24, dispôs sobre as sanções atribuíveis, "isolada, cumulativa ou alternativamente", às empresas condenadas por degradação ambiental, dividindo-as em três diferentes modalidades:

Art. 21. As penas aplicáveis isolada, cumulativa ou alternativamente às pessoas jurídicas, de acordo com o disposto no art. $3^{\circ}$, são:

I - multa;

II - restritivas de direitos;

III - prestação de serviços à comunidade.

Segundo os artigos 70, inciso VI e 173, $\S 5^{\circ}$ da Constituição Federal, as punições aplicadas às pessoas jurídicas devem ser compatíveis com sua natureza. Com a exclusão da pena privativa de liberdade, o recurso às outras medidas sancionatórias não oferece óbice ao sistema de penas à pessoa jurídica, ao menos em um primeiro momento. ${ }^{214}$

Contudo, em análise mais apurada, é possível verificar a inconstitucionalidade das penas ambientais aos entes coletivos, principalmente quanto a sua legalidade. ${ }^{215}$ A reserva legal do nullum crimen nulla poena sine lege trouxe como função essencial a publicidade $\mathrm{e}$ o prévio conhecimento dos comportamentos sociais tipificados como delitos e as correspondentes sanções aplicáveis, garantindo maior segurança jurídica na aplicação das sanções penais.

Trata-se a legalidade, portanto, de preceito, previsto no artigo $5^{\circ}$, XXXIX, da Constituição, que aspira à segurança jurídica, com o fim de garantir ao cidadão a não submissão a quaisquer coerções não predispostas em lei.

\footnotetext{
${ }^{214}$ Alguns doutrinadores ressaltam que as sanções de multa, restritivas de direitos e prestação de serviços à comunidade, cominadas aos delitos da atividade do ente coletivo, poderiam refletir em pessoas inocentes, que não tiveram participação no ato poluidor tipificado, afrontando, assim, o princípio da pessoalidade da pena (e.g. LUISI, 2001, p. 91). Ainda, existem ponderações relevantes sobre a aplicação desse tipo de medida, dadas as repercussões sociais e políticas que a paralisação de atividades empresariais pode desencadear. $\mathrm{Na}$ Espanha, JESÚS-MARÍA SILVA SÁNCHEZ (2006) observa que a aplicação dessas medidas configura-se muito tímida por parte dos juízes, por força da consideração dos reflexos trazidos aos trabalhadores e à comunidade. ${ }^{215}$ BECCARIA já prelecionava que as penas aplicáveis pelo cometimento de um delito deveriam ser decretadas por lei, sendo que a autoridade competente para essa função seria unicamente o legislador, diante das regras estabelecidas no contrato social. Deste modo, o magistrado, sem a previsão legal, estaria afastado da atribuição de infligir penas contra um membro da sociedade (BECCARIA, 1997, p. 44).
} 
O princípio da legalidade - apoiado nos requisitos de lei prévia, ${ }^{216}$ certa $^{217}$ escrita $^{218}$ e estrita ${ }^{219}$ - objetiva minimizar a incerteza e a insegurança jurídicas não apenas das tipificações de conduta, mas também das sanções aplicadas em casos de infração. Se há controvérsia de autores sobre a flexibilização do princípio da legalidade na taxatividade dos delitos ambientais, ${ }^{220}$ não há questionamento quanto à inviabilidade de as sanções criminais atenderem às exigências de anterioridade, previsibilidade, taxatividade e certeza.

Nesse contexto, destaca-se que a Lei de Crimes Ambientais brasileira mostra-se omissa quanto à modalidade e à gradação da pena aplicável nos tipos proibitivos quando da configuração do delito por atividade empresarial. ${ }^{221}$

SALVADOR NETTO (2009a, p. 101), de forma sistematizada, apresenta dois problemas imediatos que dificultam a aplicação da lei penal ambiental. Em primeiro lugar, sinaliza a falta de normas de adjudicação, visto que não há qualquer regra que estabeleça um ponto

\footnotetext{
${ }^{216}$ Lei Prévia - nullum crimen nulla poena sine praevia lege poenali: veda-se a retroatividade da lei penal em detrimento do acusado. Impõe-se a entrada em vigor da lei penal incriminadora antes do fato punível, proibindo-se que alguém seja apenado se, no momento da ação, não havia tipificação prevista em lei, e que o autor seja prejudicado com o agravamento da pena, quantitativo ou qualitativo, por lei posterior ao fato. É admissível somente que retroaja lei mais favorável ao réu, para beneficiá-lo (in bonam partem).

${ }^{217}$ Lei Certa - nullum crimen nulla poena sine lege certa: não pode haver incriminações vagas e indeterminadas. Clama-se pela clareza e exclusão da ambigüidade de termos e definições. Espera-se que a definição estabelecida pelo legislador seja precisa e inequívoca, compreensível por todos os cidadãos, expelindo-se, desse modo, tipos penais genéricos, ambíguos ou com cláusulas gerais e indeterminadas.

${ }^{218}$ Lei Escrita - nullum crimen nulla poena sine lege scripta: inibe-se a criação de crimes pelo costume. Aplica-se unicamente a lei escrita, promulgada com as previsões constitucionais que garantem sua validade no ordenamento jurídico.

${ }^{219}$ Lei Estrita - nullum crimen nulla poena sine lege stricta: proíbe-se o emprego de analogia para a criação de crimes, para a fundamentação dos mesmos, bem como para o agravamento de pena. Somente norma destinada à conduta é passível de aplicação, excluindo-se qualquer tipo de expansão lógica (analogia). Aceita-se analogia apenas se formulada em favor do acusado.

${ }^{220} \mathrm{Na}$ esfera ambiental penal, depara-se constantemente com inconstitucionalidades provenientes da ausência de taxatividade dos crimes descritos. Em contraponto, doutrinadores como GILBERTO PASSOS FREITAS e VLADIMIR PASSOS FREITAS (2001, p. 34-35) defendem a imprecisão da descrição dos tipos penais, considerando a complexidade do bem tutelado e as novas formas de lesão criadas diariamente em decorrência do irrefreável movimento de crescimento econômico. Pretende-se abarcar assim todas as lesões concretas ao meio ambiente. Entretanto, a flexibilização do princípio da legalidade significaria afronta direta ao Estado democrático de Direito, como detalha CLAUS ROXIN (1997, p. 171). Se a tutela do bem ambiental exige maior flexibilidade frente aos novos tipos de infrações surgidas, deve-se recorrer a outro ramo do direito que admita essa flexibilidade, como o Direito Administrativo, composto por uma série de regulamentações infra-legais maleáveis, que não depende do moroso processo legislativo para abarcar novas condutas.

${ }^{221}$ Perplexo, LUIZ LUISI (2001, p. 98) afirma que "é evidente que nesses casos a Lei 9.605/98 é indeterminada quanto aos fatos que constitui os crimes da pessoa jurídica aos quais se aplicam as mencionadas penas restritivas de direito. É indeterminada, ainda, quanto ao tempo de duração dessas penas, pois não há qualquer referência ao seu mínimo e ao seu máximo". Ressalta-se que, na esfera civil, o quantum a ser estipulado possui direta relação com a dimensão do dano causado; entretanto, a fixação da pena nos crimes ambientais praticados pela pessoa jurídica se defronta com a ausência de culpabilidade psicológica como parâmetro". No mesmo sentido, REALE JÚNIOR ressalta que a pessoa jurídica não tem capacidade do querer dotada de postura axiológica negativa (2001: 138). Contudo, para ALAMIRO VELLUDO SALVADOR NETTO, a culpabilidade nesses casos é normativa, configurando uma desvalorização que recai sobre a ação (2009a, p. 95), verificada por um juízo de reprovação de caráter normativo.
} 
de partida para a fixação da reprimenda, nem um raciocínio que a iguale ao quantum prisional definido à pessoa física. Inexiste, portanto, qualquer correspondência lógica ou jurídica entre as penas dos indivíduos e as dos entes coletivos. ${ }^{222}$ Por esse motivo, as empresas-rés submetem-se à exclusiva vontade do julgador para a fixação das sanções penais, sem qualquer relação de segurança jurídica (CORREA JÚNIOR e SHECAIRA, 2002, p. 458).

Em segundo lugar, aponta SALVADOR NETTO (2009a, p. 101) que o dispositivo que trata das penas aplicáveis às pessoas jurídicas vem destacado na parte geral, nos artigos 21 a 24 da Lei n. 9.605/98, ao passo que o capítulo $\mathrm{V}$ da referida lei, quando trata dos tipos penais, possui referência apenas às penas privativas de liberdade e multas, sem especificar as sanções aplicáveis às pessoas jurídicas após o preceito primário. ${ }^{223}$ Essa lacuna impossibilita a determinação de "quando e como" aplicar as penas aos entes coletivos, ${ }^{224}$ porque as normas secundárias destinadas às pessoas jurídicas não são previstas de forma concreta nos tipos penais, de modo que qualquer sanção da parte geral pode ser aplicada a qualquer injusto previsto pela lei, sem discriminação.

Cumpre destacar, também, que não houve uma estipulação do critério específico diferenciador para o cálculo da multa às pessoas jurídicas. ${ }^{225}$ Compete, portanto, ao

222 Eivadas de inconstitucionalidade, as normas penais que determinam as sanções aplicáveis às pessoas jurídicas na Lei n. 9.605/98 carecem de determinação precisa e certa, o que culmina na indefinição dos preceitos normativos, prejudicando em demasia a segurança jurídica, já que "não constam nos tipos penais as penas aplicáveis às pessoas jurídicas, mas só as físicas. Assim, como aplicar as penas contidas na parte geral da lei às pessoas jurídicas? Como fazer a integração da parte geral à parte especial? Como fazer a dosimetria da pena? O legislador não estaria colocando nas mãos do juiz um poder que não lhe incumbe ao permitir fazer a integração das penas contidas na parte geral à parte especial? $\mathrm{O}$ juiz não poderia impor a pena à pessoa jurídica sem respeitar um patamar mínimo e o máximo, podendo, inclusive, determinar o fechamento da empresa com conseqüências graves e irreversíveis à sociedade? A pessoa jurídica não tem o direito de saber de antemão a pena aplicável entre um mínimo e um máximo, bem como os tipos penais atribuídos à pessoa jurídica? As penas atribuídas às pessoas jurídicas seriam substitutivas de penas privativas de liberdade contidas na parte especial? Essa falta de integração não estaria ferindo o princípio da legalidade e o princípio da proporcionalidade da pena?" (SIRVINSKAS, 1998:23).

${ }^{223}$ Igual raciocínio é apresentado por CORREA JÚNIOR e SHECAIRA (2002, p. 455-456): "Em nenhum momento mencionou que esta ou aquela norma proibitiva deveria ser aplicada à pessoa jurídica" restando silente no que diz respeito à responsabilidade criminal da empresa nos tipos penais incriminadores.

${ }^{224}$ Além da ausência de critério de substitutividade para as penas restritivas de direito, há desconsideração do tempo de pena previsto nos tipos proibitivos da Lei de Crimes Ambientais. A mais alta pena privativa de liberdade prevista no texto normativo citado não ultrapassa cinco anos. Se fosse considerado o mais grave crime, a pena restritiva de direitos correspondente, que substitui essa imputação, equivaleria também a cinco anos. No entanto, o $\$ 3^{\circ}$ do art. 22 da referida Lei estatui que a proibição de contratar com o Poder Público não pode exceder o prazo de dez anos. Isto significa que não há qualquer relação entre as penas privativas de liberdade as restritivas de direitos.

${ }^{225}$ Como afirmam ALCEU CORREA JÚNIOR e SÉRGIO SALOMÃO SHECAIRA (2002, p. 459): "não há qualquer regra para a fixação de multa. No tipo proibitivo temos apenas a expressão pena de multa. Não há valores fixados. Também não há critérios para sua fixação na Lei Ambiental". SALVADOR NETTO destaca que "o padrão dos dias-multa utilizado na lei, face à equiparação do procedimento de fixação para as pessoas físicas e jurídicas, não apresenta qualquer razoabilidade diante dos entes coletivos, sendo incapaz, por si mesmo, de 
magistrado a fixação da multa a ser aplicada, conforme o artigo 49 do Código Penal e artigo $5^{\circ}$, inciso XLVI da Constituição Federal, segundo os quais deve ser levado em conta o caso concreto (a gravidade do delito, o grau de reprovação da conduta, a condição econômica da empresa e o resultado do dano ambiental). O pagamento da multa penal não exonera o infrator-poluidor da reparação e da indenização do dano ambiental.

A indeterminação da lei penal ambiental e de suas respectivas sanções penais afronta as bases democráticas da separação de poderes. O legislador, em sua atribuição, deveria pautar-se pela regra da proporcionalidade, submetendo o processo legislativo a exames de adequação, de necessidade e de proporcionalidade em sentido estrito, para a criação das leis restritivas de direitos fundamentais, com o objetivo de garantir, assim, o controle judicial de constitucionalidade das leis, assegurando que a restrição a direitos fundamentais não tome dimensões desproporcionais. ${ }^{226} \mathrm{Com}$ a criação de uma lei vaga, o sopesamento de princípios normalmente realizado pelo legislador é transferido para a esfera do Judiciário, que passa a regular a matéria para cada caso individual, ampliando de maneira excessiva a margem interpretativa, sem parâmetros limitadores previamente estabelecidos, o que é prejudicial para a segurança jurídica e ainda mais grave na esfera penal. $^{227}$

Além disso, o Direito Penal vê-se nessa seara distante do cumprimento da função de prevenção geral intimidatória, ${ }^{228}$ em virtude da impossibilidade de se reconhecer com clareza o que é legalmente permitido ou proibido e qual sanção pode ser atribuída à prática de uma conduta indesejável e reprovável pelo direito.

cumprir qualquer que seja a missão político-criminal do microssistema ambiental. Os padrões de percepção da capacidade econômica de uma pessoa física são totalmente distintos daqueles utilizados para as pessoas jurídicas." (2009a, p. 104).

${ }^{226}$ Ver VIRGÍLIO AFONSO DA SILVA (2002).

${ }^{227}$ Por essa razão, SALVADOR NETTO afirmou que “a própria legislação brasileira, por si só, tornou inviável qualquer responsabilidade dos entes coletivos, dada as suas fatais omissões, as quais apenas poderiam ser resolvidas pelo intérprete com clara violação de princípios penais extremamente caros ao Estado Democrático de Direito. Em sucintas palavras, poder-se-ia dizer que, mesmo com a eventual concordância político-criminal a respeito da necessidade de se tutelar criminalmente as empresas, a legislação nacional, por sua realidade positivada, inviabiliza qualquer realização neste sentido. Há, portanto, conforme já salientado, muito ainda a ser feito no âmbito legislativo" (2009a, p. 97).

${ }^{228}$ Neste sentido SALVADOR NETTO: "Embora tais órgãos não possam ser intimidados, desde muito tempo as finalidades da pena não se restringem a esta persecução, derivada da concepção liberal-racional iluminista do livre-arbítrio e da preponderância da chamada prevenção geral negativa. As funções positivas da pena, de outra forma, estão totalmente conectadas com a potencialidade da pessoa jurídica em receber os seus efeitos. A pergunta que remanesce, portanto, é exatamente se político-criminalmente é interessante e útil alçar as empresas à qualidade de sujeitos ativos de crimes e, em conseqüência, submetidas às suas respostas. Trata-se, em suma, de uma perspectiva ideológica, de escolha política, isto é, de força e poder" (2009a, p. 96 - grifos do autor). 
A lei ambiental conferiu ao julgador, pois, um poder discricionário inimaginável. ${ }^{229}$ O magistrado possui não só a capacidade de escolher a modalidade de pena (multa, restritiva de direitos ou prestação de serviços), como também a gradação dessa sanção. ${ }^{230}$ Alguns reflexos podem advir dessa arbitrariedade do julgador, como a discrepância entre julgados de casos semelhantes, insegurança jurídica, penas excessivas e desrespeito à proporcionalidade.

A previsão legal para a aplicação das sanções penais é fundamental em um Estado democrático de Direito, ${ }^{231}$ bem como a determinação dos limites máximo e mínimo entre os quais a sanção pode transitar: ${ }^{232}$

essa é a garantia estrutural que diferencia o direito penal no Estado 'de direito' do direito penal dos Estados simplesmente 'legais', nos quais o legislador é onipotente e, portanto, são válidas todas as leis vigentes, sem nenhum limite substancial à primazia da lei. E é essa diferença que hoje marca o critério de distinção entre garantismo e autoritarismo penal, entre formalismo e substancialismo jurídico, entre direito penal mínimo e direito penal máximo" (FERRAJOLI, 2002, p. 305-306).

A falta de critérios para a aplicação das penas restritivas de direito, a ausência de regra para a delimitação do quantum da pena de multa, bem como a carência de limites máximos e mínimos estabelecidos para imposição da sanção penal configuram um estado de insegurança, tanto por parte da sociedade - que não consegue prever as respostas cabíveis aos atos tipificados como crimes -, quanto pelos aplicadores da lei, desnorteados pela inexistência de sanções determinadas e adequadamente limitadas abstratamente.

\footnotetext{
${ }^{229}$ Para ALBERTO SILVA FRANCO (2000, p. 53): "Se o legislador recorrer a 'cláusulas gerais', tornando indefinida e imprecisa a definição do comportamento humano, ou se dá ao tipo 'margens penais' alargadas de forma a transformar o juiz em legislador, a arbitrariedade judicial poderá campear à solta, sem rei, nem roque".

${ }^{230}$ A perplexidade é apresentada por SALVADOR NETTO: "Se não bastasse a falta de previsão legal das penas em sua especificidade típica, o legislador apregoa que estas poderiam ser aplicadas de modo isolado, cumulativo ou alternativo. Todavia não há como responder às perguntas relativas às situações em que cada uma destas hipóteses se realizará. É impossível saber quais delitos permitem a aplicação de que pena. Quando tais penas serão cumuladas ou isoladas? Quais penas podem ser cumuladas? As penas restritivas de direitos são substitutivas ou principais? Em caso de substituição, qual é o critério" (2009a, p. 103).

${ }^{231}$ É evidente que esse controle deve estar submetido no plano formal, ao princípio da legalidade, isto é, à subordinação a leis gerais e abstratas que disciplinem as formas de seu exercício e, deve servir, no plano material, à garantia dos direitos fundamentais do cidadão" (FRANCO, 2000, p. 47).

${ }^{232}$ Sobre as vantagens e desvantagens das penas mínimas, ver SÉRIE PENSANDO O DIREITO (2009a).
} 


\section{V.3. Semelhanças com as sanções administrativas e civis.}

Em breves linhas, serão abordados alguns instrumentos adotados na esfera civil e administrativa que viabilizam a tutela ambiental e o retorno ao status quo ante. ${ }^{233}$

A Lei n. 6.938/81, além de conferir legitimidade ao Ministério Público para atuar em defesa do meio ambiente, estabeleceu o conceito de poluidor - responsável pelo dano ambiental, definido como "a pessoa física ou jurídica, de direito público ou privado, responsável, direta ou indiretamente (solidariedade passiva), por atividade causadora de degradação ambiental" (artigo $3^{\circ}, \mathrm{IV}$, do mencionado diploma legal). Inseriu-se, portanto, em nosso ordenamento a responsabilidade objetiva no que tange aos danos ambientais.

A insuficiência da responsabilidade subjetiva, dependente da comprovação de culpa ou dolo, promoveu a adoção da responsabilidade objetiva. Na realidade dos direitos difusos e coletivos, basta a comprovação da atividade de risco e o nexo causal com o dano aventado para configurar a responsabilidade pelo prejuízo ambiental, independente do elemento subjetivo. Entende-se que aquele que integra a atividade econômica e com ela lucra passa a assumir integralmente os riscos dela oriundos. Tal comando legal, no âmbito administrativo, é denominado teoria do risco ou reparação integral.

Assim, a responsabilidade primeira - mas não exclusiva - pelos danos ambientais cabe ao empreendedor ou à pessoa jurídica beneficiária dos lucros. $\mathrm{O}$ dever de zelar pelo meio ambiente decorre, nessa ótica, de seu aproveitamento econômico direto por meio da atividade lesiva. Na hipótese de existir mais de um empreendedor, a reparação poderá ser exigida de qualquer um dos responsáveis, solidariamente, em virtude da assunção comum de riscos ambientais.

Há, ainda, a responsabilidade do Estado pelo dano ambiental, por ação ou omissão, sendo o ente público também solidariamente responsabilizado pelos danos ambientais provocados por terceiros, na medida em que é de sua competência fiscalizar e impedir que tais danos aconteçam. Cabe ao Estado, por certo, direito de regresso, dependente de comprovação da responsabilidade subjetiva do funcionário público. ${ }^{234}$

Ressalta-se que a reparação dos danos causados é o comando principal da esfera civil para assegurar a preservação ambiental, embora grande parte do prejuízo causado seja

\footnotetext{
233 Além da adoção de novos mecanismos que agilizam o processo de responsabilização e execução da sanção, nestas esferas existem menos restrições, como o princípio do in dubio pro reo ou a verdade real e não presumida, dentre outras.

${ }^{234}$ PIETRO(2002, p. 507).
} 
irrecuperável, de impossível retorno ao status quo ante, tanto pela dificuldade de substituição da fauna ou flora depredada quanto pela impraticável restauração do equilíbrio de uma área devastada. Apesar de não ser sempre possível ou suficiente garantir a reparação da degradação ambiental, o princípio do poluidor-pagador é imposto como obrigação de recuperar ou, em última hipótese, indenizar pecuniariamente. Em grande parte das vezes, a esfera civil visa à reparação do dano, individual ou coletivo, exigindo reconstituição patrimonial pelos danos materiais ou imateriais decorrentes da agressão ambiental.

Outro mecanismo adotado, previsto nos artigos $3^{\circ}$ e 11 da Lei da Ação Civil Pública e artigo 84 do Código de Defesa do Consumidor, trata da tutela específica, existente nas obrigações de fazer e não fazer, em que se dá primazia à tutela condenatória sobre qualquer outra tutela ressarcitória. Há uma ordem hierárquica e escalonada do provimento jurisdicional com o fim de alcançar a tutela de recuperação ambiental almejada, mesmo que se requeiram medidas de apoio, coercitivas ou de sub-rogação. Ao se constatar inviável a entrega do objeto em espécie, tomam-se providências para assegurar um "resultado prático equivalente" ao do adimplemento, para em último caso ocorrer a conversão em perdas e danos.

No âmbito administrativo, a sanção contra danos ambientais pode ser preventiva, de advertência e repressiva. ${ }^{235}$ Ressalte-se que todas as sanções administrativas visam ao atendimento do interesse público e coletivo e à manutenção da ordem pública ambiental, razão determinante para o caráter exemplar e educacional dos instrumentos de controle ambiental, a produzir efeitos preventivos e repressivos.

Além da maleabilidade existente na esfera administrativa quanto à criação de tipos (leis, decretos, regulamentos e portarias) e da proximidade existente dos órgãos

\footnotetext{
${ }^{235}$ Segundo CELSO ANTONIO BANDEIRA DE MELLO "evidentemente, a razão pela qual a lei qualifica certos comportamentos como infrações administrativas, e prevê sanções para quem nelas incorra, é a de desestimular a prática daquelas condutas censuradas ou constranger ao cumprimento das obrigatórias. Assim, o objetivo da composição das figuras infracionais e da correlata penalização é intimidar eventuais infratores, para que não pratiquem os comportamentos proibitivos ou para induzir os administrados a atuarem na conformidade de regra que lhes demanda comportamento positivo. Logo, quando uma sanção é prevista e ao depois aplicada, o que pretende com isto é tanto despertar em quem a sofreu um estímulo para que não reincida, quanto cumprir uma função exemplar para a sociedade. Não se trata, portanto, de causar uma aflição, um 'mal', objetivando castigar o sujeito, levá-lo à expiação pela nocividade de sua conduta. $\mathrm{O}$ Direito tem como finalidade unicamente a disciplina da vida social, a conveniente organização dela, para o bom convívio de todos e bom sucesso de todo social, nisto se esgotando seu objetivo. Donde, não entram em pauta intentos de 'represália', de castigo, de purgação moral a quem agiu indevidamente. É claro que também não se trata, quando em pauta sanções pecuniárias - caso das multas -, de captar proveitos econômicos para o Poder Público, questão radicalmente estranha à natureza das infrações e, conseqüentemente, das sanções administrativas." (2007, p. 814-815).
} 
descentralizados e especializados da administração pública para fiscalização e imposição de sanções, ainda há exclusão de culpabilidade para a configuração de conduta típica punível no âmbito administrativo, o que garante maior agilidade e respostas imediatas às infrações contra o meio ambiente, afastando-se os trâmites formais e assecuratórios necessários na esfera penal.

Com esse raciocínio, amparado pelo dispositivo constitucional (artigo 225, $\S 3^{\circ}$ ) e artigo 14 da Lei n. 6.938/81, o direito positivo brasileiro delimitou algumas espécies de sanções administrativas (FREITAS, 1993, p. 352-353): i. Multa. A mais frequente, prevista em praticamente todas as leis que albergam sanções administrativas (Lei n. 9.605/98, art. 72, II, e III); ii. Advertência (Lei n. 6.894/80, art. 5, I e Lei n. 9.605/98, art. 72, I); iii. Apreensão (Lei n. 9.605/98, art. 72, IV); iv. Suspensão e redução de atividade (Lei n. 6.938/81, arts. 14, IV e 10, $\S 3^{\circ}$ e Lei n. 9.605/98, art. 72, VI e IX); v. Perda e restrição ou suspensão de benefícios fiscais ou participação em linhas de financiamento em estabelecimentos oficiais de crédito (Lei n. 6.938/81, art. 14, II e III); vi. Interdição (Lei n. 7.661/88, art. $6^{\circ}$ ); vii. Embargos de obra (Lei n. 6.513/77, art. 24, III e Lei n. 9.605/98, art. 72, VII); viii. Demolição de obra (Lei n. 9.605/98, art. 72, VIII); ix. Suspensão ou cancelamento de coisas e bens (Lei n. 7.802/89, art. 17, V e VI); x. Perdimento de coisas e bens (Lei n. 7.542/86, art. 29, §2º ); xi. Destruição de vegetais e alimentos (Lei n. 7.802/89, art. 17, IX), ou inutilização de produtos (Lei n. 9.605/98, art. 72, V); xii. Restritiva de direitos (Lei n. 9.605/98, art. 72, $\left.\mathrm{XI}^{236}\right)^{237}$

Na perspectiva administrativa, a sanção pode assumir distintas formas: perda ou restrição de benefícios fiscais, com o fim da isenção de qualquer tributo público existente; perda ou suspensão da participação em linhas de financiamento em estabelecimentos oficiais de crédito, normalmente destinados às médias, pequenas e microempresas, e perda ou restrição da participação em linhas de financiamento público; e, ainda, proibição de contratar com a administração pública pelo período de três anos, que visa a desestimular o infrator ambiental, proibindo a participação em contratos com o Poder Público.

\footnotetext{
${ }^{236}$ Art. 72. $\S 8^{\circ}$ da Lei n. 9.605/98: As sanções restritivas de direito são: I - suspensão de registro, licença ou autorização; II - cancelamento de registro, licença ou autorização; III - perda ou restrição de incentivos e benefícios fiscais; IV - perda ou suspensão da participação em linhas de financiamento em estabelecimentos oficiais de crédito; V - proibição de contratar com a Administração Pública, pelo período de até três anos.

${ }^{237}$ Não existem somente sanções administrativas ambientais previstas na Lei n. 6.938/81, sendo as menções à referida lei salientadas porque a mesma funciona como norma geral, aplicando-se nos casos em que houver lacunas deixadas pelos Estados, Distrito Federal e Municípios. Serve, pois, de piso mínimo protetivo do meio ambiente. A Lei n. 9.605/98 também prevê penalidades nos oito parágrafos de seu art. 72.
} 
Custeio de programas e de projetos ambientais, execução de obras de recuperação de áreas degradadas, manutenção de espaços públicos, contribuições a entidades ambientais ou culturais públicas equivalem, todos, às sanções reparatórias administrativas, que objetivam a recuperação do meio ambiente degradado bem como a restauração ao status quo ante.

As próprias sanções administrativas punitivas, caracterizadas pela aplicação de multas, privação de bens e de atividades na esfera ambiental, revertem em benefício da recuperação e conservação do meio ambiente, pois, conforme a legislação pátria, integram os fundos para a realização de projetos ambientais e atividades afins.

Certa amplitude foi conferida às sanções restritivas de direitos, por terem sido disciplinadas de forma genérica no art. 72, XI da Lei n. 9.605/98, traduzindo-se em toda e qualquer forma administrativa que o Poder Público puder utilizar para induzir o infrator a cessar sua prática lesiva. Dentre elas, encontra-se a suspensão parcial ou total de atividades e a interdição temporária de estabelecimento, obra ou atividade (72, IX da Lei n. 9.605/98).

Cabe destacar que as sanções administrativas ambientais, ${ }^{238}$ inseridas na categoria de ato administrativo, sujeitam-se às limitações ao poder estatal de punir, cujo intuito é respeitar os direitos e garantias individuais dos cidadãos. ${ }^{239}$ Submetem-se, pois, aos mesmos requisitos e pressupostos de validade que imprimem eficácia aos atos administrativos em geral - competência, forma, finalidade, motivo e objeto - e aos princípios que norteiam a administração pública. ${ }^{240}$

É preciso reiterar de maneira explícita uma constatação fundamental: todas as penas determinadas pela legislação brasileira aos infratores de crimes ambientais (com exceção da prisão) são idênticas às sanções civis ou administrativas nos casos de infração às normas ambientais. $^{241}$

\footnotetext{
${ }^{238}$ Sob o enfoque administrativo, denomina-se a sanção como um ato de império da Administração Pública, podendo ser conceituada como medida de autotutela da Administração imposta contra um ato resistente ao cumprimento de ordens impostas e legalmente previstas, com a finalidade de prevenção da paz social, repressão e autotutela da própria administração, além da preservação de valores que são partilhados por toda a coletividade (FIORILLO e RODRIGUES, 1997, p. 271).

${ }^{239}$ Tanto a Constituição Federal, em seu art. $5^{\circ}$, LV e art. 37, como a Lei 9.605/98, art. 70, asseguram garantias e princípios a que a administração está submetida: contraditório e ampla defesa; legalidade; impessoalidade; moralidade; e publicidade.

${ }^{240}$ Sobre princípios da administração pública, ver PIETRO (2002); BANDEIRA DE MELLO (2007).

${ }^{241}$ Cf. SALVADOR NETTO: "é inegável a diferença fática entre uma pena privativa de liberdade e qualquer outra modalidade. As demais formas de sanção apresentam violência infinitamente menor, o que as permite identificar com outras formas sancionatórias próprias do Direito Civil ou Administrativo" (2009b, p. 321).
} 
MACHADO, ao tratar dos crimes contra o sistema financeiro constatou o mesmo problema, na temática das sanções aplicáveis nas duas esferas. Alerta que a doutrina reconhece o princípio ne bis in idem no âmbito civil, no penal e no administrativo, mas, sob o argumento da independência das esferas, não o aplica entre os diferentes ramos do direito (2009: 98).

Como abordado no capítulo anterior, o princípio da intervenção mínima do Direito Penal faz com que a incidência dessa intervenção estatal gravosa ocorra nas liberdades individuais somente nos casos de lesividade mais intensas ao bem jurídico tutelado. Contudo, deve-se analisar se existem outros mecanismos (sociais, informais ou positivados) que cumprem exatamente a mesma função. Se houver, o Direito Penal, de caráter subsidiário, não deveria ser acionado. Em outras palavras, se os preceitos primários e secundários das normas ambientais, no âmbito penal e administrativo, não apresentam diferenças, não se justifica a manutenção do Direito Penal ambiental, porque outro mecanismo menos gravoso já tutela o meio ambiente, com a única diferença residindo no elemento simbólico.

Inegável a diferença entre a fundamentação das sanções penais e a das sanções administrativas a serem impostas às pessoas jurídicas. Enquanto as penalidades administrativas coíbem todas as ações em desconformidade com os regulamentos ambientais, buscando a preservação e restauração do meio ambiente, as penas derivam de tipos penais que atendem, ou deveriam atender, à política criminal adotada para que a sanção possa exercer a função a ela destinada pelo Estado democrático de Direito.

Em virtude da semelhança prática das respostas estatais à degradação ambiental, seja administrativa ou criminal, deveria haver algum fator de distinção que justificasse o acionamento idêntico de dois instrumentos paralelos de repressão. Para a diferenciação entre o ilícito penal, o administrativo e o civil, alguns autores ${ }^{242}$ adotam o critério de

\footnotetext{
${ }^{242}$ A doutrina majoritária encontra a distinção na qualidade do funcionário que aplica cada sanção; assim, ENRIQUe LASO SAYAgués (1974, p. 428) defende que "todo esto confirma que no hay diferencia de naturaleza entre los hechos constitutivos de infracciones penales y administrativas, sino criterios de diferenciación que dependen de múltiples factores: entidad del hecho, orden jurídico vulnerado, necesidad de una represión más intensa o más rápida, etc. [...] La distinción entre las sanciones penales y las administrativas radica en diversos elementos: aquellos se imponen por acto jurisdiccional, mientras que estas se aplican mediante actos administrativos; de ahí deriva que en primer caso el pronunciamiento haga cosa juzgada, mientras que en el segundo esté sujeto a contralor jurisdiccional posterior". No Brasil, no mesmo sentido se manifesta CELSO ANTONNIO BANDEIRA DE MELLO: "reconhece-se a natureza administrativa de uma infração pela natureza da sanção que lhe corresponde, e se reconhece a natureza da sanção pela autoridade competente para impô-la. Não há, pois, cogitar de qualquer distinção substancial entre infrações e sanções administrativas e infrações e sanções penais. $O$ que as aparta é única e exclusivamente a autoridade competente para impor a sanção" (2007, p. 813).
} 
reconhecimento do objeto especificamente tutelado e do órgão competente para a imposição da respectiva sanção.

Havendo um processo judicial, como via única e própria para a apuração da antijuridicidade para fins de aplicação da sanção, com exigência do exercício constitucional do devido processo legal e da entrega da tutela jurisdicional por sentença transitada em julgado, decorrerá sanção civil ou penal.

As sanções administrativas, diferentemente, decorrem de processo administrativo, sem coisa julgada, em que autoridade administrativa é responsável por verificar a existência de infração. A tutela administrativa trata dos interesses da sociedade contra os excessos de individualismo, voltando-se ao cumprimento das leis e princípios de um determinado sistema jurídico.

A distinção entre a sanção administrativa e a civil não exige muitas elaborações, já que o objeto desta é somente a reparação do dano, incidindo principalmente na esfera patrimonial. $^{243}$ Discussão mais acirrada ocorre, entretanto, quando se procura a diferenciação entre as infrações administrativas e as criminais.

A infração ambiental administrativa ${ }^{244}$ caracteriza-se pelo comportamento adverso àquele determinado pelas normas ambientais. ${ }^{245}$ Logo, para haver o exercício coercitivo da Administração é mister a existência de um tipo $^{246}$ amparado pelos elementos legalmente exigidos para delimitar uma conduta punível administrativamente. Em outros termos, a descrição da infração deve ter previsão legal ou regulamentar, em obediência ao princípio da legalidade. ${ }^{247}$

243 Ilustra-se a clivagem com o exemplo de CELSO ANTONIO PACHECO FIORILLO e MARCELO ABELHA RODRIGUES (1997, p. 266-267): “Como nos casos em que uma determinada empresa, corretamente licenciada, lance na atmosfera determinada quantidade de poluente em conformidade com os padrões exigidos pelos órgãos ambientais competentes. Nesse caso, não houve ilícito, já que está em conformidade com o sistema legal ambiental. Houve, pois uma conformidade com o que determina a lei ambiental, não se configurando infração e, portanto, não podendo incidir sanção de natureza administrativa. Todavia, admitindo que da referida liberação de efluentes no ar atmosférico tenha havido danos à fauna e flora e à saúde da população, restará, ainda, o dever de reparar civilmente pelos danos daí originados, porque a responsabilidade civil em matéria ambiental não leva em consideração a conduta ou a licitude do ato praticado, mas só o dano dele decorrente com o referido nexo que o vincule a alguém”.

${ }^{244}$ A palavra infração sempre será utilizada para indicar tipo de caráter administrativo.

${ }^{245}$ Posição convalidada pelo art. 70, caput, da Lei n. 9.605/98, que define infração administrativa como "toda a ação ou omissão que viole as regras jurídicas de uso, gozo, promoção, proteção e recuperação do meio ambiente".

${ }^{246}$ A tipicidade determinará os atos comissivos ou omissivos praticados por pessoa (física ou jurídica) contrários aos valores do sistema normativo.

${ }^{247}$ Acentua EDUARDO GARCÍA DE ENTERRÍA (1974, p. 159): "Há uma dupla vertente: por uma parte, não há infração nem sanção administrativa sem lei que as determine de maneira prévia; em segundo lugar, essa 
Poder-se-ia afirmar que as penas restritivas de direito, cuja duração equivaleria à da pena privativa de liberdade, pela Exposição de Motivos do Código Penal, §41, seriam dotadas de uma força coercitiva de que a sanção administrativa careceria, correspondente à conversão da pena restritiva de direitos em sanção privativa de liberdade, pelo tempo da pena aplicada, se injustificadamente descumprida. RENÉ ARIEL DOTTI esclarece que

a execução das penas restritivas, assim como de modo geral todas as alternativas à prisão, demandam o mecanismo coercitivo, capaz de assegurar o cumprimento e este só pode ser a pena privativa de liberdade [...] "a solução rigorosa, na aparência, vem como única fórmula capaz de assegurar o desempenho eficaz das penas restritivas, posto que, diverso fosse o entendimento adotado, dificilmente teriam garantias de exeqüibilidade, em especial na sua fase derradeira. (DOTTI, 1998, p. 382).

No campo das sanções ambientais atribuíveis às pessoas jurídicas, tal raciocínio não se sustenta, pois o descumprimento da sanção restritiva de direitos, mesmo que se convertesse em pena de prisão, não poderia acarretar o encarceramento da pessoa jurídica. Esse poder coercitivo, característico das sanções penais, perde sua aplicabilidade na referida esfera.

Por essa razão, utiliza-se como argumento possível para sustentar a sanção penal na esfera ambiental o caráter estigmatizante do direito criminal, que atenderia a uma exigência social mais elevada quanto às sanções impostas, ainda que o procedimento penal resultasse em uma medida equivalente à decorrente do administrativo ou civil. A diferença está em uma reprovação ética mais significativa ao comportamento sancionado da pessoa jurídica, dado o caráter eminentemente aflitivo da sanção penal e a suposta maior eficácia dos órgãos penais (SHECAIRA, 2003, p. 117).

Assim, as penas previstas na Lei de Crimes Ambientais às pessoas jurídicas, mesmo que meramente simbólicas - para expressar o poder coercitivo estatal em casos de atividade empresarial, - seriam necessárias como uma resposta à dramatização da violência, que advém de um processo de politização de interesse dos agentes ambientalistas, e visa a aumentar, através de expedientes repressivos, o grau de controle da sociedade sobre as empresas (FRANCO, 1993, p. 4). Em conseqüência, o Estado executa uma atuação mormente simbólica, ${ }^{248}$ com uma atividade intimidativo-dissuasória que se esgota na força ameaçadora de lei como pura coação psicológica.

previsão legal, que tem aqui além disso o caráter próprio da legalidade administrativa que conhecemos, a atribuição à Administração da potestade para sancionar tem que realizar-se justamente através da lei formal".

${ }^{248}$ Cf. SILVA SÁCHEZ: "El hecho de que las consecuencias jurídico-penales se hayan asociado tradicionamente a los hechos con un significado ético-social más grave y se impongan por un órgano independiente, y en un 
Assim, o simbolismo penal $^{249}$ pressiona os cidadãos para o cumprimento de determinações administrativas, ao criar uma inflação legislativa de tipos penais carentes de rigor legislativo.

Essa expansão do Direito Penal sobre o Direito Administrativo, facilmente observado no âmbito do meio ambiente, transforma condutas administrativas em tipos penais, devendo gerar novas considerações sobre a separação de esferas no Direito e sobre a imposição de sanções intrinsecamente unidas, ainda que de naturezas distintas. Existem funcionalidades semelhantes do Direito Administrativo e do Direito Penal em ação no âmbito ambiental. Por esse motivo, parece razoável evitar situações de dupla punição como consequência de uma mesma conduta atentatória ao meio ambiente, garantindo um relacionamento dos dois sistemas.

Há, portanto, uma nova concepção do princípio do ne bis in idem ${ }^{250}$ quando o sujeito já foi condenado na via administrativa (que pode ser até mais dura que as sanções da via penal).

\section{V.4. O enfraquecimento do Direito Penal ambiental e os instrumentos processuais da Lei n. 9.099/95}

Mesmo no pensamento de SILVA SÁNCHEZ, que expõe um Direito Penal de segunda velocidade, cujas bases estão mais distanciadas de um núcleo criminal - com penas similares às sanções administrativas, flexibilização dos critérios de imputação e diminuição das garantias político-criminais -, "a característica essencial desse setor continua sendo a judicialização" (2008b, p. 179).

proceso rodeado de las máximas garantías, atribuye a dichas consecuencias una fuerza expresiva de la que carecen las sanciones extrapenales. De modo que, aunque una sanción jurídico-penal tenga el mismo contenido fáctico que una sanción administrativa, o eventualmente uno inferior, ello no obsta a que su significado comunicativo sea muy superior. Sólo este valor comunicativo, aparte de dificultar las estrategias de neutralización, puede expresar satisfactoriamente que lo cometido es un hecho merecedor de tanto desvalor como el que es propio de las infracciones penales individuales" (2001, p. 319).

${ }^{249}$ Nesse contexto, "em que pese o fato de continuar a ser considerado merecedor e necessitado de pena nos casos de aplicação de medidas substitutivas, por exemplo, o condenado em muito é afastado daquela realidade propriamente criminal, já que suporta a condenação em todos os seus efeitos jurídicos, porém não se submete àquilo que o sistema possui de mais desumano. Nestes casos, a dimensão simbólica da punição permanece, mas sua dimensão fática é alterada." (SALVADOR NETTO, 2009b, p. 319).

${ }^{250} \mathrm{O}$ princípio do ne bis in idem tradicionalmente se configura como um direito fundamental do cidadão frente à decisão do poder público de castigá-lo por fatos que já foram objeto de sanção, como consequência do anterior exercício do ius puniendi estatal único, seja penal ou administrativo. 
Ao considerar a distinção entre os injustos penais e administrativos e suas respectivas sanções com base em uma censura moral do âmbito penal - conforme concepção apresentada por MIR PUIG e REALE JÚNIOR - ${ }^{251}$ deve-se atentar que a manutenção dessa reprovação social somente pode subsistir com o devido processo penal constitucional, dotado de instrumentos de ampla defesa, contraditório e máxima imparcialidade judicial (artigo $5^{\circ}$, LIV e LV da Constituição Federal).

Na legislação brasileira, o enfraquecimento do poder de intimidação penal - de caráter preventivo - não decorre exclusivamente da aplicação das penas restritivas de direitos em detrimento da pena de encarceramento, mas também dos instrumentos processuais previstos na Lei n. 9.099/98. A promulgação da Lei dos Juizados Especiais Criminais, apesar de ter como objetivos acelerar os processos criminais e diminuir as demandas do judiciário, gerou um efeito oposto perverso: a pena sem processo. ${ }^{252}$

O incentivo para a mediação entre o ofensor e a vítima e outros mecanismos alternativos de restabelecimento da harmonia social influenciaram a simplificação de procedimentos penais, dispensando a fase probatória, para a imediata aplicação de medidas restritivas de direitos (idênticas às penas alternativas) com base em provas preliminares de materialidade e de autoria. Antes mesmo de uma análise mais apurada sobre viabilidade da acusação $^{253}$ (subsunção dos fatos descritos à norma penal incriminadora e prévia análise da imputação), propõe-se, para evitar os trâmites do processo penal, uma conciliação entre as partes, ${ }^{254}$ transação penal ${ }^{255}$ ou suspensão condicional do processo, ${ }^{256}$ para a obtenção de uma punição com aceitação do imputado.

\footnotetext{
${ }^{251}$ Ver tópico "entre a censura administrativa e a penal", no capitulo 4.

${ }^{252}$ A própria Lei n. 9.099/95 utiliza o termo “pena”. Ver REALE JÚNIOR (1997).

${ }^{253}$ Ao criticar as medidas previstas na Lei n. 9.099/95, diante das afrontas aos princípios básicos do processo penal garantista, REALE JÚNIOR afirma que "pelo legislador brasileiro foram ignorados os riscos sabidos da condenação de inocentes com a supressão seja da investigação preliminar, seja, muito em especial, da produção probatória em juízo sob o crivo do contraditório e da ampla defesa, graças à simplificação" (2008, p. 292).

${ }^{254}$ Art. 72 da Lei n. 9.099/95: "Na audiência preliminar, presente o representante do Ministério Público, o autor do fato e a vítima e, se possível, o responsável civil, acompanhados por seus advogados, o Juiz esclarecerá sobre a possibilidade da composição dos danos e da aceitação da proposta de aplicação imediata de pena não privativa de liberdade."

${ }^{255}$ Art. 76 da Lei 9.099/95: "Havendo representação ou tratando-se de crime de ação penal pública incondicionada, não sendo caso de arquivamento, o Ministério Público poderá propor a aplicação imediata de pena restritiva de direitos ou multas, a ser especificada na proposta."

${ }^{256}$ Art. 89 da Lei n. 9.099/95: "Nos crimes em que a pena mínima cominada for igual ou inferior a um ano, abrangidas ou não por esta Lei, o Ministério Público, ao oferecer a denúncia, poderá propor a suspensão do processo, por dois a quatro anos, desde que o acusado não esteja sendo processado ou não tenha sido condenado por outro crime, presentes os demais requisitos que autorizariam a suspensão condicional da pena (art. 77 do Código Penal)."
} 
PASCHOAL, em análise do Plea Bargaining, ressalta que essa opção realizada pelo réu - dentro das especificidades do Direito Penal norte-americano -, não configura na realidade uma "escolha", porque as denúncias são infladas para desmotivar o acusado a seguir com o processo penal, sob o risco de obter uma condenação mais gravosa que o aventado acordo inicial. Segundo a autora, "a pessoa que, supostamente, teria sido beneficiada por um acordo com o promotor, na realidade (sem ter exercido a sua garantia ao devido processo penal), acaba recebendo a pena que deveria receber $\underline{\mathbf{s}}$ a acusação houvesse sido adequada, e, o que é mais importante se o Estado houvesse demonstrado a sua culpa." (PASCHOAL, 2001, p. 119, grifos da autora).

No Brasil, não houve a adoção dilatada do plea bargaining nos mesmos moldes dos Estados Unidos. ${ }^{257}$ A Lei n. 9.099/05 restringiu os benefícios para a possibilidade de composição de danos e de transação penal aos crimes de menor potencial ofensivo, classificados como aqueles com pena máxima não superior a dois anos; ${ }^{258} \mathrm{e}$ de suspensão condicional do processo aos crimes cuja pena mínima não ultrapasse um ano, sendo necessária, para essa última, a prévia formulação da denúncia e seu recebimento para a suspensão do processo.

Sob esses parâmetros objetivos, $68,4 \%$ dos crimes previstos na Lei de Crimes Ambientais (considerando o delito isolado e a pena in abstrato) admitem a aplicação de alguma das espécies de benefícios acima expostos. Apenas 31,6\% dos tipos penais vedariam, desde o princípio, a possibilidade de suspensão condicional do processo, por apresentar pena mínima superior a um ano.

Tabela: crimes ambientais da Lei n. $9.605 / 98$ que admitem os benefícios da Lei n. $9.099 / 95$

\begin{tabular}{||c||c|c||c||}
\hline Artigo & Nome & $\begin{array}{c}\text { Pena } \\
\text { Mínima }\end{array}$ & $\begin{array}{c}\text { Pena } \\
\text { Máxima }\end{array}$ \\
\hline \hline Art. 56, $1^{\circ}$ & $\begin{array}{c}\text { Abandono de produto ou substância tóxica, perigosa ou nociva à } \\
\text { saúde humana ou ao meio ambiente em desacordo com a lei } \S 1^{\circ}\end{array}$ & 1 ano & 4 anos \\
\hline \hline Art. 56, $3^{\circ}$ & $\begin{array}{c}\text { Abandono de produto ou substância tóxica, perigosa ou nociva à } \\
\text { saúde humana ou ao meio ambiente em desacordo com a lei culposo }\end{array}$ & 6 meses & 1 ano \\
\hline
\end{tabular}

${ }^{257}$ Esclarece FERNANDES: "Não se identifica com os institutos do guilty plea ou do plea bargaining, pois não há aceitação de culpa, nem há conciliação entre o Ministério Público e a defesa com a finalidade de se obter uma confissão do réu em troca de alguma vantagem, como a acusação por um crime menos grave ou de um número menor de crimes. Não há na transação da Lei 9099 aceitação de culpa. O autor do fato, ao aceitar a proposta do Ministério Público, não estará reconhecendo a sua culpa, tanto assim que não perde a primariedade e a anotação no registro criminal só terá a finalidade de impedir outra transação no prazo de cinco (5) anos" (1998, p.11).

${ }^{258}$ Segundo o art. 61 da Lei n. 9.099/95. "Consideram-se infrações penais de menor potencial ofensivo, para os efeitos desta Lei, as contravenções penais e os crimes a que a lei comine pena máxima não superior a 2 (dois) anos, cumulada ou não com multa." 


\begin{tabular}{|c|c|c|c|}
\hline Art. 32, caput & Abuso ou maus-tratos de animais silvestres & 3 meses & 1 ano \\
\hline Art. 63, caput & Alteração de aspecto ou estrutura de patrimônio protegido & 1 ano & 3 anos \\
\hline Art. 29, caput & Caça indevida da fauna silvestre & 6 meses & 1 ano \\
\hline $\begin{array}{l}\text { Art. 29, caput } \\
\text { c/c art. } 29, \S 4^{\circ}\end{array}$ & Caça indevida da fauna silvestre (com aumento de pena de $1 / 2$ ) & 9 meses & $\begin{array}{l}1 \text { ano e } \\
6 \text { meses } \\
\end{array}$ \\
\hline Art. 51, caput & Comerialização ou uso indevidos de motoserra & 3 meses & 1 ano \\
\hline $\begin{array}{l}\text { Art. } 51, \text { caput } \\
\text { c/c art. } 53 \\
\text { caput }\end{array}$ & $\begin{array}{l}\text { Comerialização ou uso indevidos de motoserra (com aumento de } \\
\text { pena de } 1 / 6 \text { a } 1 / 3 \text { ) }\end{array}$ & $\begin{array}{c}3 \text { meses e } \\
15 \text { dias }\end{array}$ & $\begin{array}{l}1 \text { ano e } \\
4 \text { meses }\end{array}$ \\
\hline $\begin{array}{l}\text { Art. } 67, \\
\text { parágrafo } \\
\text { único }\end{array}$ & $\begin{array}{c}\text { Concessão culposa e indevida de licença, autorização ou permissão } \\
\text { de atividades reguladas }\end{array}$ & 3 meses & 1 ano \\
\hline Art. 67 , caput & $\begin{array}{c}\text { Concessão indevida de licença, autorização ou permissão para } \\
\text { atividades reguladas }\end{array}$ & 1 ano & 3 anos \\
\hline Art. 52, caput & $\begin{array}{l}\text { Condução não-autorizada de instrumentos para a caça ou a } \\
\text { exploração em unidades de conservação }\end{array}$ & 6 meses & 1 ano \\
\hline $\begin{array}{l}\text { Art. } 52, \text { caput } \\
\text { c/c art. } 53 \\
\text { caput }\end{array}$ & $\begin{array}{c}\text { Condução não-autorizada de instrumentos para a caça ou a } \\
\text { exploração em unidades de conservação (com aumento de pena de } \\
1 / 6 \text { a } 1 / 3)\end{array}$ & 7 meses & $\begin{array}{l}1 \text { ano e } \\
4 \text { meses }\end{array}$ \\
\hline Art. 64, caput & Construção em solo não-edificável & 6 meses & 1 ano \\
\hline Art. 39, caput & Corte de árvores em floresta de preservação permanente & 1 ano & 3 anos \\
\hline Art. 45, caput & Corte ou transformação indevidos de madeira de lei em carvão & 1 ano & 2 anos \\
\hline Art. 60 , caput & $\begin{array}{l}\text { Criação, reforma ou movimentação indevida de obras ou } \\
\text { estabelecimentos potencialmente poluidores }\end{array}$ & 1 mês & 6 meses \\
\hline Art. 40, caput & Dano a unidade de conservação & 1 ano & 5 anos \\
\hline Art. $40, \S 3^{\circ}$ & Dano culposo a unidade de cons & 6 meses & $\begin{array}{l}2 \text { anos e } \\
6 \text { meses } \\
\end{array}$ \\
\hline $\begin{array}{l}\text { Art. } 62, \\
\text { parágrafo } \\
\text { único } \\
\end{array}$ & $\begin{array}{l}\text { Destruição, inutilização ou deteriorização culposas de patrimônio } \\
\text { público ou cultural }\end{array}$ & 6 meses & 1 ano \\
\hline Art. 62 , caput & $\begin{array}{c}\text { Destruição, inutilização ou deteriorização de patrimônio público ou } \\
\text { cultural }\end{array}$ & 1 ano & 3 anos \\
\hline $\begin{array}{l}\text { Art. } 38, \\
\text { parágrafo } \\
\text { único }\end{array}$ & Destruição ou dano culposos de floresta de preservação permanente & 6 meses & $\begin{array}{l}1 \text { ano e } \\
6 \text { meses }\end{array}$ \\
\hline $\begin{array}{l}\text { Art. } 49, \\
\text { parágrafo } \\
\text { único } \\
\end{array}$ & $\begin{array}{l}\text { Destruição ou dano culposos de plantas ornamentais de lugares } \\
\text { públicos ou privados }\end{array}$ & 1 mês & 6 meses \\
\hline $\begin{array}{l}\text { Art. } 38-\mathrm{A}, \\
\text { parágrafo } \\
\text { único }\end{array}$ & Destruição ou dano culposos de vegetação do bioma Mata Atlântica & 6 meses & $\begin{array}{l}1 \text { ano e } \\
6 \text { meses }\end{array}$ \\
\hline Art. 38, caput & Destruição ou dano de floresta de preservação permanente & 1 ano & 3 anos \\
\hline Art. 49 , caput & $\begin{array}{c}\text { Destruição ou dano de plantas ornamentais de lugares públicos ou } \\
\text { privados }\end{array}$ & 3 meses & 1 ano \\
\hline $\begin{array}{l}\begin{array}{c}\text { Art. } 49, \text { caput } \\
\text { c/c art. } 53 \\
\text { caput }\end{array} \\
\end{array}$ & $\begin{array}{c}\text { Destruição ou dano de plantas ornamentais de lugares públicos ou } \\
\text { privados (com aumento de pena de } 1 / 6 \mathrm{a} 1 / 3 \text { ) }\end{array}$ & $\begin{array}{c}3 \text { meses e } \\
15 \text { dias }\end{array}$ & $\begin{array}{l}1 \text { ano e } \\
4 \text { meses }\end{array}$ \\
\hline $\begin{array}{l}\text { Art. } 38-\mathrm{A}, \\
\text { caput }\end{array}$ & Destruição ou dano de vegetação do bioma Mata Atlântica & 1 ano & 3 anos \\
\hline Art. 50, caput & Destruição ou dano de vegetação protetora de dunas e mangues & 3 meses & 1 ano \\
\hline
\end{tabular}




\begin{tabular}{|c|c|c|c|}
\hline \begin{tabular}{|c|}
$\begin{array}{c}\text { Art. } 50, \text { caput } \\
\text { c/c art. 53, } \\
\text { caput }\end{array}$ \\
\end{tabular} & $\begin{array}{l}\text { Destruição ou dano de vegetação protetora de dunas e mangues } \\
\text { (com aumento de pena de } 1 / 6 \text { a } 1 / 3 \text { ) }\end{array}$ & $\begin{array}{c}3 \text { meses e } \\
15 \text { dias }\end{array} \mid$ & $\begin{array}{l}1 \text { ano e } \\
4 \text { meses }\end{array}$ \\
\hline Art. 61, caput & $\begin{array}{l}\text { Disseminação de praga nociva ao ecossistema, à pecuária ou à } \\
\text { agricultura }\end{array}$ & 1 ano & 4 anos \\
\hline Art. $32, \S 1^{\circ}$ & Experimentação desnecessária em animal & 3 meses & 1 ano \\
\hline \begin{tabular}{|c|} 
Art. $32, \S 1^{\circ}$ \\
c/c art. $32, \S 2^{\circ}$
\end{tabular} & \begin{tabular}{|c|} 
Experimentação desnecessária em animal (com aumento de pena de \\
$1 / 6 \mathrm{a} 1 / 3)$
\end{tabular} & \begin{tabular}{|c|}
3 meses e \\
15 dias \\
\end{tabular} & $\begin{array}{l}1 \text { ano e } \\
4 \text { meses } \\
\end{array}$ \\
\hline \begin{tabular}{|l|} 
Art. 30, caput \\
\end{tabular} & Exportação ilegal de peles e couros & 3 meses & 1 ano \\
\hline \begin{tabular}{|l|} 
Art. 44, caput \\
\end{tabular} & Extração de florestas de domínio público & 6 meses & 1 ano \\
\hline \begin{tabular}{|c|} 
Art. 44, caput \\
c/c art. 53, \\
caput
\end{tabular} & $\begin{array}{l}\text { Extração de florestas de domínio público (com aumento de pena de } \\
\qquad 1 / 6 \text { a } 1 / 3)\end{array}$ & 7 meses & $\begin{array}{l}1 \text { ano e } \\
4 \text { meses }\end{array}$ \\
\hline Art. 42, caput & Fabricação, venda ou manuseio de balão & 1 ano & 3 anos \\
\hline Art. 69-A, § $1^{\circ}$ & Falsificação culposa de laudo, estudo ou relatório ambiental & 1 ano & 3 anos \\
\hline Art. $29, \S 1^{\circ}$ & Impedimento de procriação da fauna sem licença & 6 meses & 1 ano \\
\hline \begin{tabular}{|l|} 
Art. $29, \S 1^{\circ}$ \\
c/c art. $29, \S 4^{\circ}$
\end{tabular} & $\begin{array}{l}\text { Impedimento de procriação da fauna sem licença (com aumento de } \\
\text { pena de } 1 / 2 \text { ) } \\
\end{array}$ & 9 meses & $\begin{array}{l}1 \text { ano e } \\
6 \text { meses } \\
\end{array}$ \\
\hline \begin{tabular}{|l|} 
Art. 48, caput \\
\end{tabular} & Impedimento de regeneração natural de florestas & 6 meses & 1 ano \\
\hline \begin{tabular}{|c|}
$\begin{array}{c}\text { Art. } 48, \text { caput } \\
\text { c/c art. } 53, \\
\text { caput }\end{array}$ \\
\end{tabular} & $\begin{array}{l}\text { Impedimento de regeneração natural de florestas (com aumento de } \\
\text { pena de } 1 / 6 \text { a } 1 / 3 \text { ) }\end{array}$ & 7 meses & $\begin{array}{l}1 \text { ano e } \\
4 \text { meses }\end{array}$ \\
\hline $\begin{array}{l}\text { Art. 41, } \\
\text { parágrafo } \\
\text { único } \\
\end{array}$ & Incendio culposo em floresta & 6 meses & 1 ano \\
\hline Art. 33, caput & Morte da fauna aquática pela emissão de efluentes & 3 meses & 1 ano \\
\hline $\begin{array}{l}\text { Art. } 68, \\
\text { parágrafo } \\
\text { único } \\
\end{array}$ & Não-cumprimento culposo de obrigação ambiental relevante & 3 meses & 1 ano \\
\hline \begin{tabular}{|l|} 
Art. 68 , caput \\
\end{tabular} & Não-cumprimento de obrigação ambiental relevante & 1 ano & 3 anos \\
\hline Art. 69, caput & Obstrução de atividade fiscalizadora ambiental & 1 ano & 3 anos \\
\hline Art. 66, caput & \begin{tabular}{|c|} 
Omissão ou sonegação de informações ou dados técnico-científicos \\
em procedimentos de autorização ou de licenciamento ambiental \\
\end{tabular} & 1 ano & 3 anos \\
\hline Art. 35, caput & Pesca com instrumentos ilegais & 1 ano & 5 anos \\
\hline Art. 34, caput & Pesca ilegal & 1 ano & 3 anos \\
\hline Art. 55, caput & Pesquisa, lavra ou extração indevidas de recursos minerais & 6 meses & 1 ano \\
\hline $\begin{array}{l}\text { Art. 55, caput } \\
\text { c/c art. 58, II } \\
\end{array}$ & $\begin{array}{c}\text { Pesquisa, lavra ou extração indevidas de recursos minerais (com } \\
\text { aumento de pena de } 1 / 3 \text { a } 1 / 2 \text { ) }\end{array}$ & 8 meses & $\begin{array}{l}1 \text { ano e } \\
6 \text { meses } \\
\end{array}$ \\
\hline \begin{tabular}{|c|} 
Art. 55, caput \\
c/c art. $58, \mathrm{I}$ \\
\end{tabular} & $\begin{array}{l}\text { Pesquisa, lavra ou extração indevidas de recursos minerais (com } \\
\text { aumento de pena de } 1 / 6 \text { a } 1 / 3 \text { ) }\end{array}$ & 7 meses & $\begin{array}{l}\text { ano e } \\
4 \text { meses } \\
\end{array}$ \\
\hline $\begin{array}{l}\text { Art. 55, caput } \\
\text { c/c art. 58, III } \\
\end{array}$ & $\begin{array}{l}\text { Pesquisa, lavra ou extração indevidas de recursos minerais (com } \\
\text { pena aplicada em dobro) }\end{array}$ & 1 ano & 2 anos \\
\hline Art. 65, caput & Pichação ou grafite sobre monumento urbano & 3 meses & 1 ano \\
\hline $\begin{array}{l}\text { Art. } 65, \\
\text { parágrafo } \\
\text { único } \\
\end{array}$ & Pichação ou grafite sobre monumento urbano tombado & 6 meses & 1 ano \\
\hline Art. 54, caput & Poluição & 1 ano & 4 anos \\
\hline Art. 31, caput & Introdução indevida de animal no país & 3 meses & 1 ano \\
\hline Art. 56, caput & $\begin{array}{l}\text { Manuseio de produto ou substância tóxica, perigosa ou nociva à } \\
\text { saúde humana ou ao meio ambiente em desacordo com a lei caput }\end{array}$ & 1 ano & 4 anos \\
\hline
\end{tabular}




\begin{tabular}{|c|c|c|c|}
\hline Art. $54, \S 1^{\circ}$ & Poluição culposa & 6 meses & 1 ano \\
\hline Art. $54, \S 3^{\circ}$ & Poluição por omissão & 1 ano & 5 anos \\
\hline Art. $54, \S 2^{\circ}$ & Poluição qualificada & 1 ano & 5 anos \\
\hline Art. 46, caput & Receptação ou aquisição indevidas de produtos vegetais & 6 meses & 1 ano \\
\hline $\begin{array}{l}\text { Art. } 46 \text {, caput } \\
\text { c/c art. } 53, \\
\text { caput }\end{array}$ & $\begin{array}{l}\text { Receptação ou aquisição indevidas de produtos vegetais (com } \\
\text { aumento de pena de } 1 / 6 \text { a } 1 / 3 \text { ) }\end{array}$ & 7 meses & $\begin{array}{l}1 \text { ano e } \\
4 \text { meses }\end{array}$ \\
\hline $\begin{array}{l}\text { Art. } 46, \\
\text { parágrafo } \\
\text { único } \\
\end{array}$ & Venda ou depósito indevidos de produtos vegetais & 6 meses & 1 ano \\
\hline $\begin{array}{c}\text { Art. } 46, \\
\text { parágrafo } \\
\text { único c/c art. } \\
53, \text { caput }\end{array}$ & $\begin{array}{l}\text { Venda ou depósito indevidos de produtos vegetais (com aumento de } \\
\text { pena de } 1 / 6 \text { a } 1 / 3 \text { ) }\end{array}$ & 7 meses & $\begin{array}{l}1 \text { ano e } \\
4 \text { meses }\end{array}$ \\
\hline
\end{tabular}

Tabela formulada com base nos dados de http://sispenas.mj.gov.br/sispenas/web/index.php/tipo/list/page/4

Tabela: crimes ambientais da Lei n. 9.605/98 que não admitem os benefícios da Lei $\mathbf{n}$. $9.099 / 95$

\begin{tabular}{|c|c|c|c|}
\hline Artigo & Nome & $\begin{array}{c}\text { Pena } \\
\text { Mínima }\end{array}$ & \begin{tabular}{|c|} 
Pena \\
Máxima \\
\end{tabular} \\
\hline $\begin{array}{l}\text { Art. } 56, \S 1^{\circ} \\
\text { c/c art. } 58, \text { II }\end{array}$ & $\begin{array}{l}\text { Abandono de produto ou substância tóxica, perigosa ou nociva à } \\
\text { saúde humana ou ao meio ambiente em desacordo com a lei } \S 1^{\circ} \\
\text { (com aumento de pena de } 1 / 3 \text { a } 1 / 2)\end{array}$ & $\begin{array}{c}1 \text { ano e } 4 \\
\text { meses }\end{array}$ & 6 anos \\
\hline $\begin{array}{l}\text { Art. } 56, \S 1^{\circ} \\
\text { c/c art. } 58, I\end{array}$ & $\begin{array}{l}\text { Abandono de produto ou substância tóxica, perigosa ou nociva à } \\
\text { saúde humana ou ao meio ambiente em desacordo com a lei } \S 1^{\circ} \\
(\text { com aumento de pena de } 1 / 6 \text { a } 1 / 3)\end{array}$ & $\begin{array}{c}1 \text { ano e } 2 \\
\text { meses }\end{array}$ & $\begin{array}{l}5 \text { anos e } \\
4 \text { meses }\end{array}$ \\
\hline $\begin{array}{l}\text { Art. 56, } \S 1^{\circ} \\
\mathrm{c} / \mathrm{c} \text { art. } 58, \text { III }\end{array}$ & $\begin{array}{l}\text { Abandono de produto ou substância tóxica, perigosa ou nociva à } \\
\text { saúde humana ou ao meio ambiente em desacordo com a lei } \S 1^{\circ} \\
\text { (com pena aplicada em dobro) }\end{array}$ & 2 anos & 8 anos \\
\hline Art. $56, \S 2^{\circ}$ & $\begin{array}{l}\text { Abandono de produto ou substância tóxica, perigosa ou nociva à } \\
\text { saúde humana ou ao meio ambiente em desacordo com a lei } \S 2^{\circ} \\
(\text { com aumento de pena de } 1 / 6 \text { a } 1 / 3)\end{array}$ & $\begin{array}{c}1 \text { ano e } 2 \\
\text { meses }\end{array}$ & $\begin{array}{l}5 \text { anos e } \\
4 \text { meses }\end{array}$ \\
\hline \begin{tabular}{|l|} 
Art. 29, caput \\
c/c art. $29, \S 5^{\circ}$
\end{tabular} & Caça indevida da fauna silvestre (com aumento de pena até o triplo) & $\begin{array}{c}1 \text { ano e } 6 \\
\text { meses } \\
\end{array}$ & 3 anos \\
\hline \begin{tabular}{|c|}
$\begin{array}{c}\text { Art. } 39, \text { caput } \\
\text { c/c art. } 53 \\
\text { caput }\end{array}$ \\
\end{tabular} & $\begin{array}{l}\text { Corte de árvores em floresta de preservação permanente (com } \\
\text { aumento de pena de } 1 / 6 \text { a } 1 / 3 \text { ) }\end{array}$ & $\begin{array}{c}1 \text { ano e } 2 \\
\text { meses }\end{array}$ & 4 anos \\
\hline \begin{tabular}{|c|} 
Art. 45 , caput \\
c/c art. 53 \\
caput
\end{tabular} & $\begin{array}{l}\text { Corte ou transformação indevidos de madeira de lei em carvão (com } \\
\text { aumento de pena de } 1 / 6 \text { a } 1 / 3 \text { ) }\end{array}$ & $\begin{array}{c}1 \text { ano e } 2 \\
\text { meses }\end{array}$ & $\begin{array}{l}2 \text { anos e } \\
8 \text { meses }\end{array}$ \\
\hline \begin{tabular}{|c|} 
Art. 40, caput \\
c/c art. 53
\end{tabular} & Dano a unidade de conservação (com aumento de pena de $1 / 6$ a $1 / 3$ ) & $\begin{array}{c}1 \text { ano e } 2 \\
\text { meses }\end{array}$ & \begin{tabular}{|l|}
6 anos e \\
8 meses \\
\end{tabular} \\
\hline $\begin{array}{l}\text { Art. } 50-\mathrm{A}, \\
\text { caput }\end{array}$ & $\begin{array}{l}\text { Desmatamento ou degradação indevidos de terras de domínio } \\
\text { público }\end{array}$ & 2 anos & 4 anos \\
\hline $\begin{array}{l}\text { Art. } 50-\mathrm{A} \\
\text { caput c/c art. } \\
53, \text { caput }\end{array}$ & $\begin{array}{c}\text { Desmatamento ou degradação indevidos de terras de domínio } \\
\text { público (com aumento de pena de } 1 / 6 \text { a } 1 / 3 \text { ) }\end{array}$ & $\begin{array}{c}2 \text { anos e } 4 \\
\text { meses }\end{array} \mid$ & $\begin{array}{l}5 \text { anos e } \\
4 \text { meses }\end{array}$ \\
\hline $\begin{array}{c}\begin{array}{c}\text { Art. } 38, \text { caput } \\
\text { c/c art. } 53 \\
\text { caput }\end{array} \\
\end{array}$ & $\begin{array}{l}\text { Destruição ou dano de floresta de preservação permanente (com } \\
\text { aumento de pena de } 1 / 6 \text { a } 1 / 3 \text { ) }\end{array}$ & $\begin{array}{c}1 \text { ano e } 2 \\
\text { meses }\end{array}$ & 4 anos \\
\hline
\end{tabular}




\begin{tabular}{|c|c|c|c|}
\hline $\begin{array}{l}\text { Art. } 38-\mathrm{A} \\
\text { caput c/c art. } \\
53, \text { caput } \\
\end{array}$ & $\begin{array}{l}\text { Destruição ou dano de vegetação do bioma Mata Atlântica (com } \\
\text { aumento de pena de } 1 / 6 \text { a } 1 / 3 \text { ) }\end{array}$ & $\begin{array}{c}1 \text { ano e } 2 \\
\text { meses }\end{array} \mid$ & 4 anos \\
\hline $\begin{array}{c}\text { Art. } 42 \text {, caput } \\
\text { c/c art. } 53 \\
\text { caput }\end{array}$ & $\begin{array}{l}\text { Fabricação, venda ou manuseio de balão (com aumento de pena de } \\
\qquad 1 / 6 \text { a } 1 / 3)\end{array}$ & $\begin{array}{c}1 \text { ano e } 2 \\
\text { meses }\end{array} \mid$ & 4 anos \\
\hline \begin{tabular}{|l|} 
Art. $29, \S 1^{\circ}$ \\
c/c art. $29, \S 5^{\circ}$ \\
\end{tabular} & $\begin{array}{c}\text { Impedimento de procriação da fauna sem licença (com aumento da } \\
\text { pena até o triplo) }\end{array}$ & \begin{tabular}{|c|}
$\begin{array}{c}1 \text { ano e } 6 \\
\text { meses }\end{array}$ \\
\end{tabular} & 3 anos \\
\hline Art. 41, caput & Incêndio em floresta & 2 anos & 4 anos \\
\hline $\begin{array}{l}\text { Art. } 41 \text {, caput } \\
\text { c/c art. } 53\end{array}$ & Incêndio em floresta (com aumento de pena de $1 / 6$ a $1 / 3$ ) & \begin{tabular}{|c|}
$\begin{array}{c}\text { anos e } 4 \\
\text { meses }\end{array}$ \\
\end{tabular} & \begin{tabular}{|l|}
5 anos e \\
4 meses \\
\end{tabular} \\
\hline $\begin{array}{l}\text { Art. } 56, \text { caput } \\
\text { c/c art. } 58, \text { II }\end{array}$ & $\begin{array}{l}\text { Manuseio de produto ou substância tóxica, perigosa ou nociva à } \\
\text { saúde humana ou ao meio ambiente em desacordo com a lei caput } \\
\text { (com aumento de pena de } 1 / 3 \text { a 1/2) }\end{array}$ & $\begin{array}{c}1 \text { ano e } 4 \\
\text { meses }\end{array} \mid$ & 6 anos \\
\hline $\begin{array}{l}\text { Art. } 56, \text { caput } \\
\text { c/c art. } 58, \text { I }\end{array}$ & $\begin{array}{c}\text { Manuseio de produto ou substância tóxica, perigosa ou nociva à } \\
\text { saúde humana ou ao meio ambiente em desacordo com a lei caput } \\
\text { (com aumento de pena de } 1 / 6 \mathrm{a} 1 / 3)\end{array}$ & $\begin{array}{c}1 \text { ano e } 2 \\
\text { meses }\end{array}$ & $\begin{array}{l}5 \text { anos e } \\
4 \text { meses }\end{array}$ \\
\hline $\begin{array}{l}\text { Art. 56, caput } \\
\text { c/c art. } 58, \text { III }\end{array}$ & $\begin{array}{l}\text { Manuseio de produto ou substância tóxica, perigosa ou nociva à } \\
\text { saúde humana ou ao meio ambiente em desacordo com a lei caput } \\
\text { (com pena aplicada em dobro) }\end{array}$ & 2 anos & 8 anos \\
\hline $\begin{array}{l}\text { Art. 54, caput } \\
\text { c/c art. 58, II }\end{array}$ & Poluição (com aumento de pena de $1 / 3$ a $1 / 2$ ) & \begin{tabular}{|c|}
$\begin{array}{c}1 \text { ano e } 4 \\
\text { meses }\end{array}$ \\
\end{tabular} & 6 anos \\
\hline \begin{tabular}{|c|} 
Art. 54, caput \\
c/c art. 58, I \\
\end{tabular} & Poluição (com aumento de pena de 1/6 a 1/3) & \begin{tabular}{|c|}
$\begin{array}{c}1 \text { ano e } 2 \\
\text { meses }\end{array}$ \\
\end{tabular} & \begin{tabular}{|l|}
5 anos e \\
4 meses \\
\end{tabular} \\
\hline $\begin{array}{l}\text { Art. 54, caput } \\
\text { c/c art. 58, III } \\
\end{array}$ & Poluição (com pena aplicada em dobro) & 2 anos & 8 anos \\
\hline $\begin{array}{l}\text { Art. } 54, \S 3^{\circ} \\
\text { c/c art. } 58, \text { II } \\
\end{array}$ & Poluição por omissão (com aumento de pena de 1/3 a 1/2) & \begin{tabular}{|c|}
1 ano e 4 \\
meses
\end{tabular} & \begin{tabular}{|l|}
7 anos e \\
5 meses \\
\end{tabular} \\
\hline $\begin{array}{l}\text { Art. } 54, \S 3^{\circ} \\
\text { c/c art. } 58, \mathrm{I} \\
\end{array}$ & Poluição por omissão (com aumento de pena de $1 / 6$ a 1/3) & \begin{tabular}{|c|}
$\begin{array}{c}1 \text { ano e } 2 \\
\text { meses }\end{array}$ \\
\end{tabular} & $\begin{array}{l}6 \text { anos e } \\
8 \text { meses } \\
\end{array}$ \\
\hline \begin{tabular}{|l|} 
Art. $54, \S 3^{\circ}$ \\
c/c art. 58, III \\
\end{tabular} & Poluição por omissão (com pena aplicada em dobro) & 2 anos & 10 anos \\
\hline $\begin{array}{l}\text { Art. } 54, \S 2^{\circ} \\
\text { c/c art. } 58, \text { II } \\
\end{array}$ & Poluição qualificada (com aumento de pena de 1/3 a 1/2) & \begin{tabular}{|c||}
1 ano e 4 \\
meses
\end{tabular} & $\begin{array}{l}7 \text { anos e } \\
5 \text { meses } \\
\end{array}$ \\
\hline $\begin{array}{l}\text { Art. } 54, \S 2^{\circ} \\
\text { c/c art. } 58, \mathrm{I}\end{array}$ & Poluição qualificada (com aumento de pena de 1/6 a 1/3) & \begin{tabular}{|c|}
1 ano e 2 \\
meses
\end{tabular} & \begin{tabular}{|l|}
6 anos e \\
8 meses \\
\end{tabular} \\
\hline \begin{tabular}{|l|} 
Art. $54, \S 2^{\circ}$ \\
c/c art. 58, III \\
\end{tabular} & Poluição qualificada (com pena aplicada em dobro) & 2 anos & 10 anos \\
\hline $\begin{array}{c}\text { Art. } 69-\mathrm{A}, \\
\text { caput }\end{array}$ & Falsificação de laudo, estudo ou relatório ambiental & 3 anos & 6 anos \\
\hline Art. 69-A, $\S 2^{\circ}$ & \begin{tabular}{|c} 
Falsificação de laudo, estudo ou relatório ambiental (com aumento \\
de pena de $1 / 3$ a $2 / 3$ )
\end{tabular} & 4 anos & 10 anos \\
\hline
\end{tabular}

Tabela formulada com base nos dados de http://sispenas.mj.gov.br/sispenas/web/index.php/tipo/list/page/4

Reitera-se que, nos crimes de menor potencial ofensivo e naqueles com pena mínima não superior a um ano, o acusado pode ser levado a abdicar de seu direito de ser julgado com a devida instrução probatória e prévia análise de mérito da imputação, aceitando uma sanção penal eminentemente por temer o processo. ${ }^{259}$ No caso dos crimes

${ }^{259}$ Sobre a utilização do processo como forma de coerção, ver CARNELUTTI (2002). 
ambientais previstos na Lei n. 9.605/98, isso pode ocorrer com mais da metade dos tipos penais, se não houver cumulação e vedação de requisitos subjetivos.

SALVADOR NETTO defende a aplicação de medidas processuais alternativas, admitindo um nível de dúvida distinto do existente na sentença, em razão da menor relevância da infração do dever e do resultado verificado no caso concreto. Nessa situação, faculta-se ao acusado a opção de arcar com ônus como um mínimo de invasão na esfera de liberdade do cidadão (2009b, p. 325), ou seja, com mecanismos de admissão de outras consequências penais, por meio da transação e suspensão condicional do processo.

Apesar de esse modelo indicar que o acusado não reconhece a culpa ao aceitar a proposta feita pelo Ministério Público e que o procedimento não gera reincidência, a aceitação de uma coerção penal traz uma carga inerente de estigma social. REALE JÚNIOR (2008, p. 301) afirma que a sentença homologatória de transação penal configura efetivamente "uma sentença condenatória", ${ }^{260}$ visto que a imposição de penas previstas no Código Penal ao acusado não pode ser interpretada como uma sentença absolutória. Ademais, essa sentença constitui título executivo penal, que impede novo procedimento com os mesmos fatos e a possibilidade de nova transação penal nos cinco anos subsequentes.

Usualmente, pela lógica da celeridade processual, promotores, juízes e advogados tendem a essas soluções trazidas pela Lei n. 9.099/95. Para o primeiro grupo, não há necessidade de buscar provas e base para uma acusação sólida apta a gerar uma condenação. Para o segundo, o encerramento do processo em seu início representa um número menor de trâmites e audiências nas varas criminais. E, para o último, o esforço na busca de alternativas para a absolvição, ou redução da pena, é poupado, bastando um acordo que encerra a questão sem ônus adicionais (como o de recorrer a instâncias judiciais superiores). Desse modo, “o Processo Penal engole o Direito Penal e se transforma em um fim em si mesmo, tendo-se por único objetivo a quantidade de produção rápida de decisões para desfazer a sobrecarga de trabalho da Administração da Justiça e de seus partícipes." (REALE JÚNIOR, 2008, p. 303).

A Lei n. 9.605/98 está inserida nesse contexto. O Supremo Tribunal Federal, em julgamento de 21/06/2005 do habeas corpus 85.747/SP, sob relatoria do Ministro Marco Aurélio, reconheceu, em processo versando sobre crime ambiental, que:

${ }^{260}$ Cf. em sentido diverso, BITENCOURT (1996). 
diante de verdadeira pressão psicológica quanto a ter assento no banco dos réus e ficar sujeito à tramitação processual, a processo-crime, aceitou a proposta de suspensão processual sem, no entanto, conceber a própria existência da ação. É que, no caso, não se contaria com fato típico quer considerada a definição do ilícito penal, quer a insignificância do gravame, da lesão resultante do ato praticado. Assevera-se que a imputação de o paciente haver promovido 'bosqueamento' de vegetação rasteira em pequena propriedade rural, visando a instalar cerca nos respectivos limites, não implicou dano ambiental suficiente a atrair a glosa almejada com a denúncia

Destaca-se que a Lei de Crimes Ambientais, além de admitir expressamente a aplicação dos institutos da Lei n. 9.099/95, ainda alberga dois dispositivos específicos sobre as hipóteses de transação e suspensão condicional do processo:

Art. 27. Nos crimes ambientais de menor potencial ofensivo, a proposta de aplicação imediata de pena restritiva de direitos ou multa, prevista no art. 76 da Lei ${ }^{\circ} 9.099$, de 26 de setembro de 1995, somente poderá ser formulada desde que tenha havido a prévia composição do dano ambiental, de que trata o art. 74 da mesma lei, salvo em caso de comprovada impossibilidade.

Art. 28. As disposições do art. 89 da Lei no 9.099, de 26 de setembro de 1995, aplicam-se aos crimes de menor potencial ofensivo definidos nesta Lei, com as seguintes modificações:

I - a declaração de extinção de punibilidade, de que trata o $\S 5^{\circ}$ do artigo referido no caput, dependerá de laudo de constatação de reparação do dano ambiental, ressalvada a impossibilidade prevista no inciso I do $\S 1^{\circ}$ do mesmo artigo;

II - na hipótese de o laudo de constatação comprovar não ter sido completa a reparação, o prazo de suspensão do processo será prorrogado, até o período máximo previsto no artigo referido no caput, acrescido de mais um ano, com suspensão do prazo da prescrição;

III - no período de prorrogação, não se aplicarão as condições dos incisos II, III e IV do $\S 1^{\circ}$ do artigo mencionado no caput;

IV - findo o prazo de prorrogação, proceder-se-á à lavratura de novo laudo de constatação de reparação do dano ambiental, podendo, conforme seu resultado, ser novamente prorrogado o período de suspensão, até o máximo previsto no inciso II deste artigo, observado o disposto no inciso III;

V - esgotado o prazo máximo de prorrogação, a declaração de extinção de punibilidade dependerá de laudo de constatação que comprove ter o acusado tomado as providências necessárias à reparação integral do dano. (grifos nossos).

Nos termos dos artigos acima mencionados, a transação penal depende de prévia composição do dano ambiental, salvo sua comprovada impossibilidade. Buscou-se, pela via da Justiça Consensual, solucionar matérias penais e civis, admitindo-se a prorrogação de prazos, reiteradas vezes, para a restauração do dano ambiental.

Em relação ao artigo 28 da Lei n. 9.605/98, destaca-se que o dispositivo legal limitou a aplicação da suspensão condicional do processo somente aos crimes ambientais 
de menor potencial ofensivo, quando a Lei dos Juizados Especiais admite sua aplicação para todos os delitos com pena mínima não superior a um ano. Argumenta FERNANDES que "se aplica integralmente o artigo 89, da Lei 9099 aos crimes ambientais, pois a intenção do legislador foi apenas a de modificar, com os incisos I a V, as normas sobre os requisitos para a concessão da suspensão ou sobre as condições de seu cumprimento, tendo havido erro na alusão aos crimes de menor potencial ofensivo.” (1998, p. 19).

Embora a argumentação para aplicação da transação e suspensão condicional do processo seja a celeridade processual, observa-se, no Direito Penal ambiental, que se torna possível prolongar a utilização do sistema criminal a fim de forçar o acusado (que pode não ser o autor da infração) a reparar o dano verificado no meio ambiente. Em outras palavras, a extinção da punibilidade após a suspensão condicional do processo está vinculada à existência de laudo de constatação da reparação ambiental, que, se não for integral, pode submeter o acusado à extensão de mais quatro anos para o feito, acrescido ainda mais um ano, nos termos do inciso II, e admitindo-se ainda nova prorrogação por mais cinco anos, até o laudo de constatação que comprove todas as providências necessárias para a reparação integral do dano.

Além do enfraquecimento do Direito Penal ambiental com as formulações precárias do injusto penal e a carência de efeitos manifestos das penas, vê-se, paralelamente, um enfraquecimento do processo penal, visto que a premissa nulla poena sine judicio é fragilizada, ${ }^{261}$ o que agrava ainda mais a aplicação da intervenção jurídico-penal nas questões relacionadas ao meio ambiente.

Para os fins do presente trabalho, merecem destaque duas características das sanções aplicáveis aos crimes ambientais. Primeiro, a identidade que guardam com sanções administrativas e civis, a justificar inúmeras críticas ao emprego do Direito Penal para a proteção do meio ambiente. Em segundo lugar, a escassa aplicação das penas ambientais, que cedem espaço aos instrumentos processuais previstos na Lei n. 9.099/95. Combinadas, estas características fragilizam as justificativas para a guarida penal dos bens ambientais, uma vez que as finalidades tradicionais das penas claramente não são preservadas nesta seara.

\footnotetext{
${ }^{261}$ Assim: "O processo ganha autonomia e a tarefa está em dar uma eficiente e pouco custosa resposta a esta provocação consistente na possibilidade de ocorrência de um crime, para se demonstrar a capacidade produtora da fábrica de decisões em série, com desprezo aos fins da pena - preventivo, reeducativo, retributivo - pois o aspecto funcional deve prevalecer sobre o substancial ${ }^{261}$, na linha própria do pensamento pós-moderno" (REALE JÚNIOR, 2008, p. 305).
} 


\section{A LEI DE CRIMES AMBIENTAIS E SEUS IMPACTOS NOS TRIBUNAIS BRASILEIROS}

Após tratar no plano teórico das questões relativas às finalidades das penas nos crimes contra o meio ambiente, questiona-se se a legislação penal ambiental - restringida neste tópico à Lei n. 9.605/98 - teria sido aplicada pelos tribunais brasileiros ${ }^{262}$ e em quais termos. $^{263}$

Busca-se confirmação para a hipótese exposta nos capítulos anteriores de que o Direito Penal ambiental, em lugar de se legitimar pela função instrumental de proteção de bens jurídicos, a reprovar somente as lesões mais graves ao meio ambiente, direcionou-se para uma função simbólica. ${ }^{264}$

Seguindo os indicadores apresentados por HELENA REGINA LOBO DA COSTA (2010, p. 140) para averiguação da legislação simbólica de proteção penal ambiental, e consequentemente do teor simbólico das penas, destaca-se que não há muito a se acrescentar quanto às considerações traçadas pela autora sobre (i) as circunstâncias de criação da norma e (ii) o componente de engano, como será exposto a seguir. Contudo, a presente análise dos julgados dos tribunais superiores pode auxiliar no atinente (iii) à incapacidade estrutural para produção de efeitos instrumentais e (iv) à inefetividade instrumental da norma.

Em relação às circunstâncias de criação da norma, reitera-se, à luz do exposto por COSTA (2010, p. 145), que, de fato, o projeto legislativo da Lei n. 9.605/98 tramitou em caráter de urgência e foi rapidamente aprovado, diante da pressão eleitoral e midiática a

262 Merece destaque a observação de DIAS a respeito da aplicação do Direito Penal econômico: "Nomeadamente, parece indiscutível a dificuldade, que um pouco por toda a parte se nota, das instâncias persecutórias formais - em especial dos first-line-enforcers, isto é: das polícias e do ministério público - em abandonarem uma atitude re-activa em favor de uma atitude pró-activa neste domínio. Por último, as consabidas dificuldades de prova judiciária com que aqui se depara - em especial quando o autor real do delito seja uma pessoa colectiva - e que conduzem, também um pouco por toda a parte, a que seja excepcionalmente alta neste âmbito a percentagem de absolvições.” (2006, p. 63-64).

${ }^{263}$ Segundo ANITUA, os doutrinadores da escola de análise econômica do direito, mediante complicados cálculos de custos e benefícios, "justificavam elevar os máximos punitivos, argumentando que a modificação legislativa comportaria muito menos gastos do que o que implicaria um reforço nas agências de justiça para permitir a perseguição penal" (2008, p. 796). Com isso, buscava-se uma aplicação comunicativa da norma, independente da aplicação efetiva pelos tribunais.

${ }^{264}$ A função simbólica já foi exposta nos capítulos anteriores, mas merece a ressalva de que é entendida, neste trabalho, como a lei penal em que preponderam os efeitos latentes sobre os manifestos e cujas penas encontram legitimação em uma prevenção geral positiva extremista, de teor exclusivamente comunicativo, dissociada de resultados efetivos na proteção do bem jurídico de relevância penal. 
respeito do incêndio ocorrido em Roraima, em janeiro de 1998, destinando-se pouca atenção aos aspectos técnicos e à racionalidade legislativa. ${ }^{265} \mathrm{O}$ caráter de leicompromisso, em que o resultado de interesses contrapostos resulta em um acordo nãoharmonioso, foi verificado na edição da Lei de Crimes Ambientais, fruto das contendas entre setores de produção e grupos defensores da preservação ambiental, que desencadearam incongruências normativas e deficiente construção do injusto penal, expostas nos capítulos anteriores.

Sobre o componente engano, não se pode negar a sensação de rapidez na resolução do problema socialmente verificado, eis que o legislador atuou de modo célere na promulgação da Lei n. 9.605/98. Mais que proteger o meio ambiente, o intuito do texto normativo foi sinalizar a presteza da resposta penal, mesmo que de pouca efetividade. Depara-se neste exemplo, pois, com uma "contraprodutividade do uso simbólico do direito penal, que ocorre por meio da despolitização, descontextualização e individualização do problema" (COSTA, 2010, p. 147). Como expresso anteriormente, a manutenção da falsa expectativa nas finalidades das sanções penais (prevalência dos efeitos simbólicos sobre os instrumentais) acarreta uma acomodação do poder político na busca de soluções efetivas. $^{266}$

No que se refere à incapacidade estrutural para produção de efeitos instrumentais, o presente trabalho indicou, nos capítulos anteriores, as deficiências na construção do injusto penal. Desse contexto provém a hipótese - a ser averiguada na pesquisa empírica de que não só diversos tipos penais da Lei n. 9.605/98 já nasceram simbólicos, pela sua inviabilidade de aplicação no plano concreto, como há dificuldade de o magistrado subsumir os fatos descritos nas redações legislativas (de excessiva imprecisão técnica, a exemplo do "em níveis tais" do crime de poluição ambiental). Além disso, a falta de fragmentariedade da proteção penal ambiental, que amplia o Direito Penal para uma gama excessiva de condutas, resulta, como também se pretende verificar, no acionamento de

${ }^{265}$ Cf. ATIENZA (1997). Sobre a questão da técnica e racionalidade legislativa, ver LUIZ GUILHERME MENDES PAIVA (2009), que busca, por meio da análise da Lei de Crimes Hediondos, identificar quais critérios informam a discussão sobre a formulação de leis penais no Congresso Nacional.

${ }^{266}$ COSTA, criticando o efeito contraprodutivo da norma, indica alguns instrumentos a que o Poder Público deveria atentar: "O direito penal simbólico na seara do meio ambiente dificulta, portanto, a busca desses mecanismos específicos, como, por exemplo, tematizar as formas de produção e de consumo, incentivar certificações ambientais, o estabelecimento de programas de compliance ambiental nas empresas, o desenvolvimento de seguros ambientais, a conscientização dos consumidores e a consolidação de variáveis ambientais como um diferencial do produto. Tais instrumentos são mais adequados às características dos sistemas econômico e ambiental e poderiam apresentar uma efetividade protetiva maior do que o direito penal, até porque mais flexíveis, mais amplos e mais adequados à 'linguagem' desses sistemas” (2010, p. $150)$. 
poucos tipos penais da Lei n. 9.605/98, além de gerar insegurança, como no caso da responsabilização da pessoa jurídica.

O ponto central da análise jurisprudencial, conduto, repousa na inefetividade instrumental da norma, diante do escasso material oriundo de estudos empíricos em relação ao Direito Penal ambiental no Brasil.

Embora a correlação fosse válida à época, as taxas de desflorestamento da Amazônia mencionadas por COSTA (2010, p. 141) como demonstração de que, mesmo após a edição da Lei n. 9.605/98, não houve decréscimo no desmatamento entre 1995 a 2004, não se apresentam uniformes após 13 anos de vigência da Lei de Crimes Ambientais.

Verifica-se, nos anos seguintes a 2004, que houve uma significativa diminuição dos índices de desflorestamento da Floresta Amazônica, segundo dados apresentados pelo Instituto Nacional de Pesquisas Espaciais - INPE. ${ }^{267}$

\begin{tabular}{|c|c|c|c|c|c|c|c|c|c|c|c|}
\hline & & \#imgs/ano & 162 & 192 & 208 & 212 & 212 & 214 & 216 & 213 & 93 \\
\hline Estados\Ano & 00 & 01 & 02 & 03 & 04 & 05 & 06 & 07 & 08 & 09 & 10 \\
\hline Acre & 547 & 419 & 883 & 1078 & 728 & 592 & 398 & 184 & 254 & 167 & 273 \\
\hline Amazonas & 612 & 634 & 885 & 1558 & 1232 & 775 & 788 & 610 & 604 & 405 & 474 \\
\hline Amapá & & 7 & 0 & 25 & 46 & 33 & 30 & 39 & 100 & 70 & 0 \\
\hline Maranhão & 1065 & 958 & 1085 & 993 & 755 & 922 & 674 & 631 & 1271 & 828 & 679 \\
\hline Mato Grosso & 6369 & 7703 & 7892 & 10405 & 11814 & 7145 & 4333 & 2678 & 3258 & 1049 & 828 \\
\hline Pará & 6671 & 5237 & 7510 & 7145 & 8870 & 5899 & 5659 & 5526 & 5607 & 4281 & 3710 \\
\hline Rondônia & 2465 & 2673 & 3099 & 3597 & 3858 & 3244 & 2049 & 1611 & 1136 & 482 & 427 \\
\hline Roraima & 253 & 345 & 84 & 439 & 311 & 133 & 231 & 309 & 574 & 121 & 0 \\
\hline Tocantins & 244 & 189 & 212 & 156 & 158 & 271 & 124 & 63 & 107 & 61 & 60 \\
\hline Amazônia Legal & 18226 & 18165 & 21651 & 25396 & 27772 & 19014 & 14286 & 11651 & 12911 & 7464 & 6451 \\
\hline
\end{tabular}

Fonte: INPE

Observa-se, pelo gráfico do INPE, ${ }^{268}$ que a taxa de desmatamento na Amazônia Legal sofreu acentuada oscilação desde 1988; nos últimos anos, porém, desde 2004, os índices foram inferiores a $2.000 \mathrm{~km}^{2} / \mathrm{ano}$, em linha decrescente:

${ }^{267}$ Pretendeu-se apresentar quadro semelhante ao trabalho de COSTA, para que fosse viável a comparação. Neste sentido, consultou-se igualmente o Instituto Nacional de Pesquisas Espaciais. Monitoramento da Floresta Amazônica Brasileira por Satélite: Projeto PRODES. Disponível em $<$ http://www.obt.inpe.br/prodes/prodes_1988_2010.htm>. Acesso em 20.12.2010.

${ }^{268}$ Instituto Nacional de Pesquisas Espaciais. Monitoramento da Floresta Amazônica Brasileira por Satélite: Projeto PRODES. Disponível em <http://www.obt.inpe.br/noticias/arquivos/pdf/grafico1_prodes2009.pdf>. Acesso em 20.12.2010. 


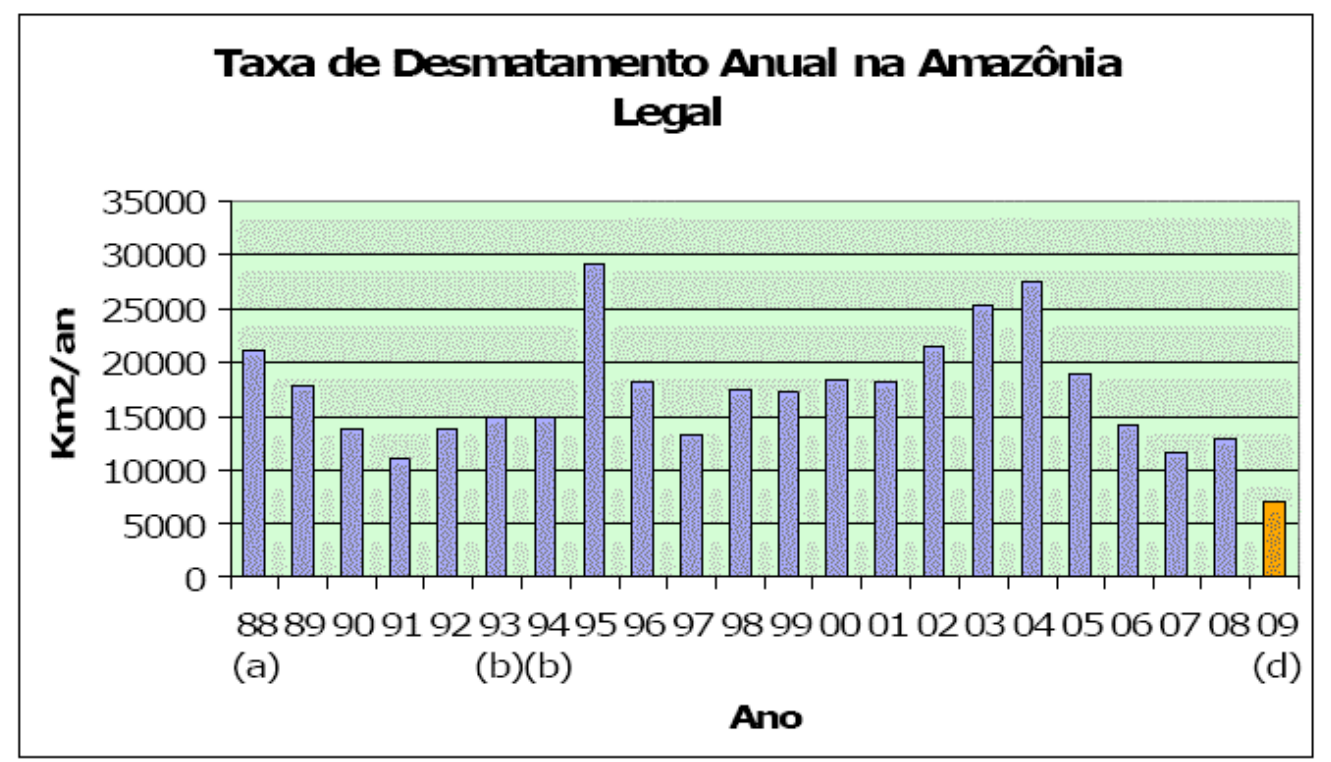

(a) Média entre 1977 e 1988 (b) Media entre 1993 e 1994 (d) Taxa Estimada

Fonte: INPE

Isso não significa afirmar que a Lei de Crimes Ambientais, por si só, gerou essa alteração do panorama ambiental. Cumpre notar que nos últimos tempos, a temática da preservação ambiental ganhou evidência no âmbito nacional e internacional, ${ }^{269}$ como exemplificam os discursos presidenciais das eleições de 2010.

Além disso, mesmo que a legislação penal tenha auxiliado na construção de uma ética ambiental, reitera-se o argumento trazido por MÜLLER-TUCKFELD (2000), de que o importante não são os efeitos produzidos pela lei, mas se esses efeitos são legítimos. Nesta linha de raciocínio, a busca por uma legitimação das penas - pelas finalidades instrumentais - ganha relevância, visto que a intimidação abstrata da norma penal pode, de fato, gerar uma abdicação da prática de determinadas condutas por parte da sociedade. Contudo, se esse êxito se verifica exclusivamente com base em efeitos simbólicos, podemos estar diante de uma legislação penal ilegítima.

Assim, mais importante do que buscar a efetividade instrumental da Lei n. 9.605/98 no índice de desflorestamento da Amazônia, optou-se pela pesquisa jurisprudencial, com o intuito de apurar se a legislação penal ambiental apenas gera intimidação social diante das sanções penais previstas abstratamente, ou se há efetiva aplicação das penas em condenações por crimes contra o meio ambiente.

${ }^{269}$ Sobre a ética ecológica social, ver FABÍLA EMELIN RODRIGUES (2006), em tópico sobre "Mídia e Meio Ambiente". 
Por meio de análise empírica, procura-se verificar a aplicabilidade judicial das sanções penais no âmbito da legislação penal ambiental, a fim de se constatar a quantidade de casos julgados, as condenações nos tribunais superiores e o grau de aplicação das penas previstas no ordenamento - principalmente às pessoas jurídicas (em razão da inovação legislativa trazida pela Lei n. 9.605/98 ao ordenamento brasileiro).

O objetivo preliminar da pesquisa empírica era analisar a aplicação prática da Lei de Crimes Ambientais, diante da verificação de uma série de construções dogmáticas problemáticas na formação dos tipos penais ambientais. Deparou-se porém com duas dificuldades preliminares. Primeiro, a necessidade de se analisar os dados existentes em primeira instância (acompanhando-os até a última instância para se comprovar o resultado final do julgamento, com o trânsito em julgado da decisão condenatória). Para ser viável, tal esforço exigiria recortes metodológicos estritos, afastando a pesquisa de sua pretendida amplitude analítica nacional. Além disso, demandaria conhecimentos avançados de estatística, para garantir parâmetros corretos de amostragem, frente à impossibilidade física de se consultar todos os processos.

A segunda dificuldade está relacionada com a suposição de que muitos casos penais ambientais sejam resolvidos por via processual ou por acordos (antes mesmo de se iniciar qualquer procedimento penal) - por exemplo com a utilização de institutos despenalizantes da Lei n. 9.099/95 e dos Termos de Ajustamento de Condutas (TAC) efetuados com o órgão ministerial. Nesta seara, infelizmente, não existem registros e bancos de dados unificados sobre a aplicação de transações, de acordos, bem como de suspensões condicionais do processo, mormente quando não ocorrem nas varas dos Juizados Especiais Criminais. ${ }^{270}$ Ao se deparar com a inviabilidade desta pesquisa abrangendo decisões desde a primeira instância, diante dos limites temporais deste trabalho, optou-se pela busca de resultados nas instâncias superiores, a fim de se averiguar a incidência de casos referentes à Lei n. 9.605/98 em âmbito nacional.

O resultado apresentado a seguir, além de assistir a análise da função simbólica da pena e da utilização do processo penal como meio de coerção, sinaliza a existência de

270 Esclarece-se que os crimes passíveis de aplicação da suspensão condicional do processo não obrigatoriamente atraem a competência dos Juizados Especiais Criminais, podendo ser aplicados igualmente nas varas criminais comuns da Justiça Estadual e Justiça Federal, conforme dispõe o artigo 89 da Lei n. 9.099/95. 
instrumentos alternativos que impedem a sentença penal condenatória ou a transformam em medida desnecessária. ${ }^{271}$

\section{VI.1. Tribunais superiores}

\section{A) Metodologia}

Inicialmente a pesquisa dedicou-se ao levantamento de jurisprudência nas páginas eletrônicas da rede mundial de computadores (Internet) ${ }^{272}$ do Supremo Tribunal Federal $(\mathrm{STF})^{273}$ e do Superior Tribunal de Justiça $(\mathrm{STJ})^{274}$, por representarem os órgãos do Poder Judiciário que se manifestam em último grau de jurisdição, ${ }^{275}$ quando esgotadas as vias recursais das decisões proferidas nos Tribunais de segunda instância de todo país.

A jurisprudência do STJ e STF, além de indicar a posição predominante do Poder Judiciário sobre determinado tema, em razão da influência de seu posicionamento nas

${ }^{271}$ Eventualmente, outro projeto de pesquisa possa, com base nesse primeiro, aprofundar institutos do Termo de Ajustamento de Conduta, suspensão condicional do processo e a reparação do dano, a fim de abordar a possibilidade de renúncia da pena em casos de desnecessidade (WOLTER e FREUND, 2004).

${ }^{272} \mathrm{O}$ âmbito da pesquisa ficou restrito aos julgados disponíveis nas bases de dados online dos tribunais mencionados (www.stf.jus.br; www.stj.jus.br). Ao tratar dos resultados obtidos, busca-se indicar o total de julgados disponíveis no site, para que se tenha conhecimento do universo trabalhado.

${ }^{273} \mathrm{Na}$ página eletrônica do STF, segundo informações da seção de pesquisa de jurisprudência do tribunal, estão disponibilizados todos os acórdãos publicados a partir de 06/07/1950 na seção "Inteiro Teor de Acórdãos”. Entretanto, a busca jurisprudencial indica somente os acórdãos selecionados como principais. Os demais são incluídos no campo "Acórdãos no mesmo sentido", que estão inseridos na pesquisa do acórdão principal, com teses similares, e podem ser acessados em seu inteiro teor pelo número do acórdão.

${ }^{274}$ Segundo informações da página do Superior Tribunal de Justiça, todos os acórdãos julgados, desde que já publicados na imprensa oficial, ficam disponíveis na base de dados acessível pela internet:

"A pesquisa de jurisprudência é disponibilizada na Internet e Intranet. Podem ser pesquisados:

- todos os acórdãos e súmulas do Superior Tribunal de Justiça, desde que já publicados na imprensa oficial;

- as decisões monocráticas do STJ publicadas desde abril de 1999; e,

- ementas selecionadas e todas as súmulas do extinto Tribunal Federal de Recursos.

O sucesso da Pesquisa de Jurisprudência depende do bom uso das ferramentas de pesquisa e da existência de documentos sobre o tema na base de dados, posto que as matérias decididas no Superior Tribunal de Justiça restringem-se a poucos assuntos, com certeza não abarcando em sua totalidade os mais variados temas que podem ser localizados em Tribunais de Justiça do País. Isso ocorre em virtude da restrita possibilidade de recursos, constitucionalmente previstos, cabíveis aos Tribunais Superiores e do tempo decorrido até que um novo tema infraconstitucional alcance as portas do STJ. Após realizar a pesquisa pessoalmente, se o usuário encontrar dificuldades em localizar documentos relevantes poderá encaminhar sua solicitação por e-mail à nossa Seção de Pesquisa de Jurisprudência."

http://www.stj.jus.br/webstj/Processo/Jurisp/PesquisaResumoEstruturado/TiraDuvidas.asp?vPortalArea=804 \&vPortalAreaPai=459\&vPortalAreaRaiz=333 (acesso em 09 de novembro de 2010).

${ }^{275}$ Embora a análise dos Recursos Extraordinário e Especial tenha conteúdo limitado, não se pode negar que o Supremo Tribunal Federal e o Superior Tribunal de Justiça manifestam-se, por último, nas questões relativas aos debates jurisdicionais, conforme os artigos 102 a 105 da Constituição Federal. 
instâncias inferiores, ${ }^{276}$ traz também o panorama brasileiro sobre o objeto estudado, haja vista as demandas tratadas nestes tribunais derivarem de decisões tanto da Justiça Estadual quanto da Federal e, no caso específico do Supremo Tribunal Federal, da Justiça Recursal dos Juizados Especiais Criminais (estaduais e federais).

Nesse sentido, ressalta-se que, em decorrência da significativa extensão territorial brasileira e da vasta diversidade ambiental existente, uma análise jurisprudencial nacional (por via do STJ e STF) mostra-se relevante para apreciar a aplicação dos tipos penais previstos na Lei de Crimes Ambientais em todo o país. Certamente, uma análise regionalizada em apenas um Tribunal de Justiça estadual ou federal poderia gerar dados distorcidos, uma vez que a inexistência de determinada característica ambiental poderia gerar a absoluta inaplicação de um determinado crime pelo Poder Judiciário local. É o exemplo do artigo 38-A da Lei n. 9.605/98, cuja redação prevê a destruição ou danificação de vegetação primária ou secundária do Bioma Mata Atlântica, de impossível subsunção aos atos de degradação contra a flora ocorridos na Região Norte do Brasil, onde este tipo de vegetação não existe.

Como a hipótese trabalhada neste tópico tem seu viés direcionado à pena, a pesquisa limitou-se às decisões meritórias definitivas ancoradas na legislação penal ambiental, que ocorrem em sede de Recurso Extraordinário e Recurso Especial, no STF e no STJ, respectivamente. Há de se observar, portanto, que, para o interesse desta pesquisa, buscaram-se as decisões penais condenatórias de modo a se verificar as penas aplicadas no caso concreto. Em outras palavras, não foram consideradas as decisões de habeas corpus, tampouco as que tratavam de absolvições, prescrições $^{277}$ ou questões processuais (competência, nulidade processual etc.).

O levantamento de dados restringiu-se temporalmente ao período de vigência da Lei de Crimes Ambientais, sancionada em 12 de fevereiro de 1998, o que perfaz menos de 13 anos até a presente data. ${ }^{278}$ Valendo-se dos termos "Recurso Especial E crime

\footnotetext{
${ }^{276}$ A influência em instâncias inferiores ocorre tanto pela cristalização de um posicionamento reiterado dos Tribunais Superiores, quanto pelas súmulas vinculantes, cuja regulamentação ocorreu, em nosso ordenamento, com a emenda constitucional $n^{\circ} 45$ de 2004.

${ }^{277}$ Como a pesquisa jurisprudencial limita-se ao âmbito do processo de conhecimento, não se faz referência à prescrição da pretensão executiva do Estado, mas tão-somente aos casos de prescrição da pretensão punitiva, seja da pena em concreto, seja da pena em abstrato. Ainda que estas duas últimas situações apresentem distinção - na primeira há uma sentença condenatória com definição de pena ao caso concreto e na segunda considera-se a cominação legal abstrata prevista no tipo normativo -, desconsideram-se ambos os casos, para o resultado das sentenças finais condenatórias, diante da impossibilidade de execução da pena.

${ }^{278} \mathrm{O}$ período final da pesquisa refere-se a outubro de 2010.
} 
ambiental" no STJ, "Recurso Extraordinário E crime ambiental" no STF, em pesquisa preliminar exploratória, obteve-se o seguinte resultado: ${ }^{279}$

\begin{tabular}{|l|c|}
\hline Tribunal & $\begin{array}{c}\text { "Recurso Especial E crime ambiental" / "Recurso } \\
\text { Extraordinário e crime ambiental" }\end{array}$ \\
\hline STJ & 71 ocorrências \\
\hline STF & 7 ocorrências \\
\hline
\end{tabular}

O número escasso de decisões finais demonstra que a investigação empírica da temática é realizável na análise dos julgados em sua íntegra, não sendo necessária a análise por amostragem ou meramente pela ementa. O universo de resultados obtidos precisou ainda ser submetido a uma nova triagem, factível em vista dos instrumentos de pesquisa disponibilizados, para separação de decisões absolutórias e decisões condenatórias. Só então, a partir dessa clivagem, foi possível dimensionar as sanções efetivamente aplicadas pelos tribunais superiores.

\section{B) Supremo Tribunal Federal - STF}

A começar pelo Supremo Tribunal Federal, órgão de última instância do Poder Judiciário Brasileiro, duas questões principais merecem comentários.

Em primeiro lugar, no exercício de sua função de guardião da Constituição Federal, o Supremo Tribunal Federal decide as ações que versam sobre a constitucionalidade das normas, de forma concentrada (art. 102, I, a, da Constituição Federal). Embora se tenha destacado ao longo deste trabalho diversas ofensas constitucionais na Lei de Crimes Ambientais em matéria penal, foram encontrados apenas três casos de Ação Direta de Inconstitucionalidade com menção à Lei n. 9.605/98, cujos conteúdos, porém, não dialogavam com o âmbito criminal. ${ }^{280}$

Sobre a matéria tratada no presente trabalho, não houve, pelo mecanismo de controle concentrado de constitucionalidade, debate sobre as carências verificadas em

\footnotetext{
${ }^{279}$ Resultados obtidos entre os dias 25 e 26 de março de 2009.

${ }^{280}$ A ADI n. 2.714-0 versa sobre a análise de atos normativos de natureza secundária, em casos de infração administrativa prevista no art. 70 da Lei n. 9.605/98. A ADI n. 2.622-4 trata de normas sobre o Ministério Público do Estado de Rondônia e, em apenas um argumento, faz referência a outro acórdão que citou a Lei n. 9.605/98, sem tratar do mérito ecológico. Finalmente, a ADI n. 2.083-8 aborda a aplicação da Lei n. 9.605/98 e da Medida Provisória n. 1.874-15 para celebração de Termos de Ajustamento de Condutas a infrações administrativas.
} 
relação às sanções penais impostas às pessoas jurídicas, tampouco sobre a afronta ao princípio da proporcionalidade das penas no Direito Penal ambiental.

Em segundo lugar, no que concerne à análise constitucional com critério puramente técnico-jurídico dos casos concretos, verificou-se que a página eletrônica do Supremo Tribunal Federal apresenta exígua quantidade de 58 ocorrências referentes à Lei n. 9.605/98. ${ }^{281}$ Dentre estas, somente 17 (29,31\%) versavam sobre Recursos Extraordinários, ou seja, decisões definitivas, em um universo de 95.150 Recursos Extraordinários disponíveis no mecanismo de busca utilizado.

O procedimento metodológico utilizado para o levantamento de dados na página do Supremo Tribunal Federal está representado no quadro abaixo. Os termos de pesquisa (A), (B) e (C) foram inseridos no campo "pesquisa livre"; os termos de pesquisa (D) mesclaram "recurso adj extraordinário" no campo "pesquisa livre" e "LEI-009605" no campo de "legislação"; e, por último, os termos de pesquisa (E) foram inseridos somente no campo pertinente à legislação, conforme exposto em nota anterior.

\begin{tabular}{|l|l|}
\hline (A) Recurso adj Extraordinário e crimes adj ambientais & $\begin{array}{l}\text { ACÓRDÃOS 7 documentos encontrados (Todos os } \\
\text { acórdãos estão incluídos na pesquisa D) }\end{array}$ \\
\hline (B) Recurso adj extraordinário e 9605 & Nenhum documento encontrado \\
\hline $\begin{array}{l}\text { (C) Recurso adj extraordinário e meio adj ambiente e } \\
\text { crime }\end{array}$ & $\begin{array}{l}\text { ACÓRDÃOS 5 documentos encontrados (Todos os } \\
\text { acórdãos estão incluídos na pesquisa D) }\end{array}$ \\
\hline (D) Recurso adj extraordinário e LEI-009605 & $\begin{array}{l}\text { ACÓRDÃOS 12 documentos encontrados } \\
\text { "acórdãos no mesmo sentido" }\end{array}$ \\
\hline (E) LEI-009605 & $\begin{array}{l}\text { ACÓRDÃOS 52 documentos encontrados + } \\
\text { "acórdãos no mesmo sentido" }\end{array}$ \\
\hline
\end{tabular}

Após analisar individualmente cada um dos 17 acórdãos encontrados referentes a Recursos Extraordinários, observou-se que o universo de julgados diminuiu para apenas 15 (25,86\% do total de 58 ocorrências), visto que dois documentos não tratavam de questão penal ambiental, mas faziam referência à Lei n. 9.605/98 tão-somente na argumentação. ${ }^{282}$

Do reduzido grupo de 15 julgados em sede de Recurso Extraordinário sobre matéria penal ambiental, contatou-se que o Supremo Tribunal Federal, em quase 13 anos de vigência da Lei de Crimes Ambientais, não julgou nenhum caso proveniente de decisão

\footnotetext{
${ }^{281}$ Na página eletrônica do Supremo Tribunal Federal, existem sete campos ou filtros para a realização de pesquisa jurisprudencial: pesquisa livre; número; ministro; data; órgão julgador; ementa/indexação; legislação. Diante do objetivo de verificar a quantidade de acórdãos referentes à Lei n. 9.605/98 desde sua vigência, somente o campo pertinente à "legislação" foi preenchido com "Lei Ordinária (LEI)" e o número " 9605 ", para que todos os julgados que fizessem referência a essa normativa fossem selecionados. Destaca-se que inicialmente houve a incidência de 52 acórdãos principais, sendo somado a este número 6 acórdãos indicados em "acórdãos no mesmo sentido".

${ }^{282}$ RE n. 430105 QO/RJ e RE n. 502915/SP.
} 
condenatória recorrível. Em regra, os casos submetidos ao STF trataram de Recursos Extraordinários de decisões de Recursos em Sentido Estrito contra decisão sobre não recebimento de denúncia ou sobre conflito de competência estadual ou federal. O quadro abaixo sintetiza a incidência temática dos 15 recursos analisados: ${ }^{283}$

\section{Tipo de decisão}
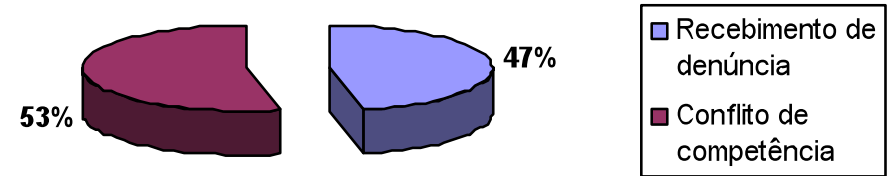

Elaboração própria

Diante desses dados, o objetivo de analisar as penas aplicadas no âmbito do Direito Penal ambiental restou prejudicado, podendo-se concluir somente pela inaplicação da Lei n. 9.605/98 pelo Supremo Tribunal Federal em decisões meritórias definitivas.

Questiona-se o porquê da falta de pronunciamento do STF sobre o mérito das decisões condenatórias penais ambientais. Poder-se-ia justificar pela edição da súmula $n$. 279 do referido Tribunal, que veda o reexame de prova em sede de Recurso Extraordinário. Ocorre que, da análise das decisões judiciais levantadas, esta hipótese não se verifica, visto que não há, nem ao menos, um único caso de não conhecimento de recurso em decisões meritórias, dado que a temática sequer foi levada ao STF por via recursal, seja para condenação, seja para absolvição.

Outra hipótese seria considerar a Lei n. 9.605/98 demasiadamente nova, de modo que o trâmite do judiciário não teria permitido a chegada destes recursos ao STF pela necessidade de esgotamento das medidas recorríveis anteriores. Contudo, essa hipótese parece pouco plausível ao se considerar a existência de condenações no STJ datadas de 2003 e 2005, há pelo menos cinco a sete anos (como exposto a seguir).

Apesar de o Supremo Tribunal Federal ter um âmbito de análise de conteúdo restrito a questões constitucionais, conforme disposto no art. 102 da Constituição Federal, a pequena quantidade de decisões no STF sobre a questão penal ambiental - mesmo em

\footnotetext{
${ }^{283} \mathrm{O}$ gráfico indica porcentagens aproximadas para facilitar a visualização.
} 
análise expandida para as demais vias recursais (Ação Direta de Inconstitucionalidade e Habeas Corpus) - provoca inquietação. Principalmente ao se considerar que, dos $95^{284}$ injustos penais previstos na Lei de Crimes Ambientais, 44 têm competência originária nos JECrims. ${ }^{285}$ Em outras palavras, quase cinquenta por cento dos crimes previstos na Lei $\mathrm{n}$. 9.605/98 são direcionados para a esfera dos Juizados Especiais Criminais, se não cumulados com outros crimes. Se houver decisão condenatória nesta instância, o recurso é encaminhado para o colégio recursal, que somente admite recurso meritório para o Supremo Tribunal Federal. ${ }^{286}$ Diante deste panorama, uma explicação para a ausência de Recursos Extraordinários provenientes de decisão condenatória dos Juizados Especiais Criminais pode ser a inaplicação da Lei dos Crimes Ambientais nos JECrims nas sentenças condenatórias. $\mathrm{Ou}$, ainda, o conformismo dos acusados ou dos representantes do Ministério Público frente às decisões condenatórias ou absolutórias proferidas, que os desmotivaria a acionar a via recursal. Alternativamente, a explicação poderia repousar na utilização de outros mecanismos que impedem o resultado meritório do processo, encerrando-o com procedimentos processuais ou consensuais. ${ }^{287}$

O dado de que 44 dos 95 delitos ambientais da Lei n. 9.605/98 têm pena máxima igual ou inferior a dois anos pode indicar uma dificuldade de os recursos alcançarem os

\footnotetext{
${ }^{284}$ Levantamento realizado pelo SISPENAS. Ressalte-se que a pesquisa discrimina os "tipos simples" dos "tipos mistos": "o conjunto de tipos passou a ser composto por (a) normas de conduta e sanção já determinadas pela lei penal; e (b) normas de conduta e sanção resultantes de combinações feitas pela equipe de pesquisa com as chamadas causas de aumento (majorantes) e causas de diminuição da pena (minorantes)." (SÉRIE PENSANDO O DIREITO, 2009b, p. 20).

${ }^{285}$ A competência mencionada considera os crimes isolados, sem cumulação com outros delitos e sem complexidade probatória. Se houver cumulação e a somatória das penas ultrapassar 2 anos, ou se o crime for de difícil apuração, a competência será da Justiça Comum. Neste sentido, relata LÉLIO BRAGA CALHAU (2004), promotor de justiça: "Situação que poderá ser enfrentada com certa freqüência nas infrações ambientais será a de fatos complexos, cuja apuração demandará investigações minuciosas e que irão requerer maior tempo. Deverá ser aplicado, então, o artigo 77, parágrafo $2^{\circ}$, da Lei dos Juizados Especiais Criminais. [...] Isso acaba gerando maior trâmite no procedimento de apuração, pois a perícia é fundamental para a avaliação da medida a ser tomada quando da ocorrência do crime ambiental. Não havendo acordo, o feito tramita primeiro pelo juizado especial criminal, é dada baixa no sistema de controle do Poder Judiciário e o mesmo passa a tramitar na justiça criminal ordinária.”

${ }^{286}$ Conforme entendimento da súmula 640 do STF: "é cabível recurso extraordinário contra decisão proferida por juiz de primeiro grau nas causas de alçada, ou por turma recursal de juizado especial cível e criminal'. Se o instrumento de impugnação contra decisão proferida pelo colégio recursal for o habeas corpus, este será analisado pelo Tribunal de Justiça ou Tribunal Regional Federal, diante do entendimento do Tribunal do Pleno do STF de que não mais prevalece a súmula 690 do STF.

${ }^{287}$ Novamente LÉLIO BRAGA CALHAU (2004) relata sua experiência, como promotor de justiça, no momento anterior ao recebimento de denúncia: "o que se vê é uma enxurrada de arquivamentos neste momento processual, com os famosos pareceres e sentenças chapinhas, perfeitamente formais no plano jurídico, mas, desconectados com a realidade ambiental. Diversos promotores e juízes alegam insignificância, política criminal, perdão judicial etc, tudo no intuito de se livrar do processo (digo: problema ambiental), que, para muitos, não seria o caso de se transformarem em processo, pois, entendem, que deveria ser resolvido na seara administrativa."
} 
tribunais superiores diante do transcurso do lapso prescricional, tanto com base na pena abstrata quanto na concretamente fixada. ${ }^{288}$

A afirmação peremptória que se pode fazer do levantamento jurisprudencial apresentado acima é que as penas previstas na legislação penal ambiental (Lei n. 9.605/98) não são aplicadas pelo Supremo Tribunal Federal, nos acórdãos de Recurso Extraordinário.

A existência de debates processuais, ${ }^{289}$ sem condenações, por ora, confirma a tese de que a Lei de Crimes Ambientais valoriza uma intimidação processual, pautada nas penas previstas abstratamente (prevenção geral), sem a efetiva aplicação das sanções penais previstas na Lei n. 9.605/98, no caso concreto.

Em pouco menos de 13 anos de vigência da lei, não houve nenhuma decisão condenatória sobre a questão penal ambiental nos Recursos Extraordinários do STF e, dos 15 recursos analisados versando sobre a Lei n. 9.605/98, oito foram julgados em 2008, seis em 2002 e o primeiro a trazer essa matéria ao Supremo Tribunal Federal foi julgado em 2001.

Considerando todas as 58 incidências sobre a Lei n. 9.605/98, os julgados dividemse no tempo conforme exposto no quadro abaixo:

\section{Número de julgados por ano}

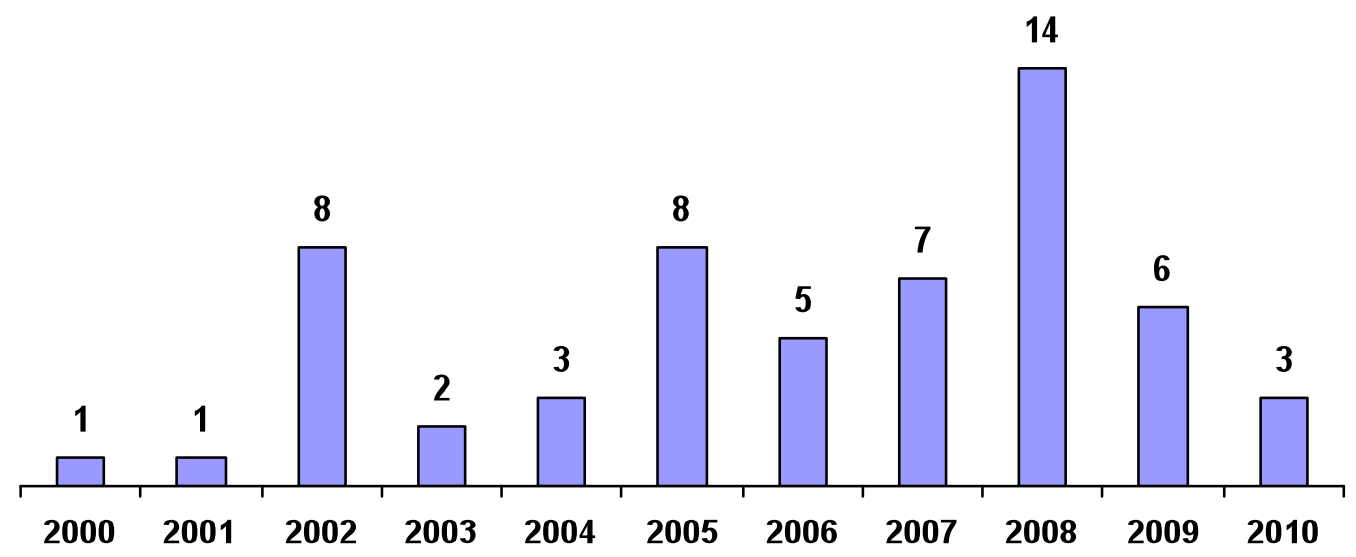

Elaboração própria

\footnotetext{
${ }^{288}$ Em análise preliminar no TJRS, verificou-se que são inúmeros os casos de prescrição, muito embora, grande parte das decisões faça referência à período anterior à alteração legislativa que não mais prevê a prescrição in concreto entre a data do fato e o recebimento da denúncia.

${ }^{289}$ Utiliza-se a ideia de debates processuais aos casos em que há processo-crime em andamento, com debates técnicos em trâmite, como por exemplo a inépcia da denúncia ou o conflito de competência, sem haver ainda discussão sobre a questão substancial de tipicidade e imputação.
} 
Nos últimos três anos, pode verificar-se uma diminuição do número de julgados apreciados sobre a temática da Lei n. 9.605/98. Isso pode ter ocorrido por uma estabilização do posicionamento do Supremo Tribunal em relação a determinados assuntos, como os de competência. Sem embargo, ainda que haja essa redução do número de julgados de 2008 para $2010,{ }^{290}$ percebe-se, pelos anos anteriores, que ainda existe uma instabilidade quanto à demanda e aplicação da lei, surgindo elevações em alguns períodos e regressões em outros.

Para concluir, apesar de a análise sobre a aplicação de penas às pessoas jurídicas ter sido prejudicada pelos resultados obtidos, é interessante notar que, nos 15 acórdãos analisados de Recursos Extraordinários em matéria penal ambiental, 14 julgados tratam de processos iniciados contra pessoas físicas e apenas 1 (um) versa sobre pessoa física e jurídica conjuntamente ${ }^{291}$ (dupla imputação, SHECAIRA, 2003, p. 148). Em oposição ao que apregoa parte da doutrina, verifica-se que a Lei de Crimes Ambientais incide, ao menos nos casos analisados no STF, sobre pessoas físicas, que, em tese, teriam menos potencial lesivo ao meio ambiente que as pessoas jurídicas.

\section{Réu (15 acórdãos)}
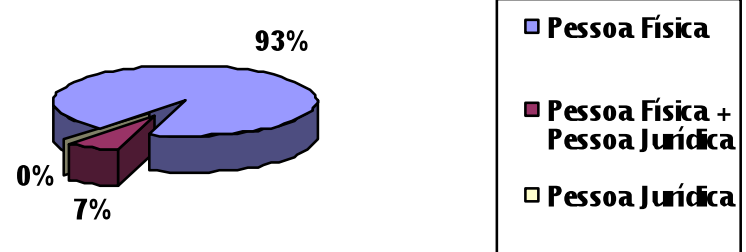

Elaboração própria

Diante do resultado pouco expressivo dos Recursos Extraordinários, buscou-se, em um segundo momento, analisar os 38 acórdãos restantes ${ }^{292}$ com o escopo de verificar se a

\footnotetext{
${ }^{290} \mathrm{O}$ ano de 2010 foi considerado somente até o mês de outubro.

${ }^{291}$ Não se verificou nenhum caso de processo em que uma pessoa jurídica figurasse isoladamente no pólo passivo da ação penal.

${ }^{292}$ Os 38 acórdãos restantes são resultado da exclusão dos 17 Recursos Extraordinários já analisados e das 3 Ações Diretas de Constitucionalidade comentadas, do total de 58 acórdãos encontrados referentes à Lei n. 9.605/98.
} 
questão das penas havia sido tratada em sede distinta de recurso final meritório. Neste mister, houve a apreciação de 34 habeas corpus, uma reclamação, dois inquéritos e uma ação penal originária, conforme demonstrado, em termos percentuais, no quadro abaixo.

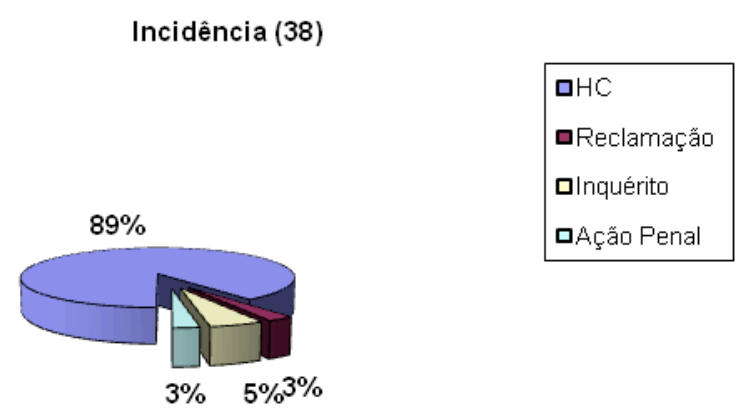

Elaboração própria

Apesar de o universo de acórdãos analisados ser mais amplo, somente quatro (10,5\%) acórdãos dos 38 apreciados versam sobre condenações penais (HC n. 93.442-1, HC n. 89.735-5, HC n. 83.437-0 e HC n. 84.821-4). Os demais tratam principalmente de impugnação da ação penal por inépcia da denúncia e falta de justa causa, além de alguns casos de prisão indevida.

No habeas corpus n. 93.442-1 de São Paulo, o relator Ministro Menezes Direito, em julgamento de 25 de março de 2.008, entendeu incabível a impetração do remédio constitucional, diante de óbice jurídico-processual proveniente de entendimento sumular, ${ }^{293}$ que inviabiliza apreciação, em sede de habeas corpus, de questão concernente à pena de multa.

No caso em tela, o paciente, pessoa física, foi condenado, em primeira instância, à pena de sete anos de reclusão, pela somatória de três anos por infração do artigo 50, inciso I e III, e parágrafo único, incisos I e II, cumulado com o artigo 51, ambos da Lei n. 6.766/79 e quatro anos de reclusão por infração do artigo 40, cumulado com o artigo 53, ambos da Lei n. 9.605/98, acrescida do pagamento de multa de 100 vezes o salário mínimo.

O loteamento clandestino em uma das encostas da Serra da Cantareira, em unidade de conservação ambiental, desencadeou punição pela ausência de regulamentação e por causar dano direto ao Cinturão Verde de São Paulo. Entretanto, em âmbito recursal, o

${ }^{293}$ Menção à súmula 693 do Supremo Tribunal Federal. 
Tribunal de Justiça de São Paulo reformou a sentença, fixando o regime prisional semiaberto para o desconto inicial das respectivas penas privativas de liberdade.

Não fosse a cumulação de delitos, a quantidade de pena aplicada ao crime referente à Lei n. 9.605/98 atenderia o requisito do art. 44, I, do Código Penal de substituição para penas restritivas de direitos. O delito de causar dano direto ou indireto às Unidades de Conservação tem pena abstrata prevista de 1 a 5 anos. No caso, além de elevar a pena-base, houve ainda aplicação da causa de aumento do artigo 53 da Lei n. 9.605/98.

X. O Julgador de $1^{\circ}$ grau utilizou, como fundamento para a elevação da pena-base acima do mínimo legal, a culpabilidade dos pacientes (dolo que teve por alvo pessoas humildes, leigas e de boa fé), os motivos do crime (a ganância na divisão da gleba de terra em 1.250 lotes a serem vendidos a 18 mil reais cada), suas condutas sociais (descaso com os Poderes Públicos) e as conseqüências do crime (algumas das vítimas correm o risco de ter suas residências desmoronadas por força da erosão causada pelo loteamento).

XI. O dolo intenso, a ganância, o desrespeito para com os Poderes Públicos e os riscos que correm os compradores dos lotes localizados nas terras irregularmente parceladas pelos pacientes constituem um plus ao crime de loteamento clandestino, praticado na sua forma qualificada, não sendo, pois, inerentes ao tipo penal. [itálico do original]. (HC 49.607/SP, Relator Ministro Gilson Dipp, Quinta Turma, d.j. 29/06/2006).

Ainda sem decisão definitiva, ${ }^{294}$ a pena sofreu novamente alteração com o debate realizado por via de habeas corpus no STJ sobre o excessivo rigor e insuficiente fundamentação para o cálculo do quantum dos dias-multa. ${ }^{295}$ Em razão deste julgado, reduziu-se a pena pecuniária de 100 para 10 dias-multa, considerando que a pena-base da condenação não foi imposta no máximo previsto em lei e, na mesma proporção, o máximo não pode ser aplicado para a pena de multa.

No habeas corpus n. 89.735-5 de São Paulo, novamente se pretendeu tecer debate sobre a dosimetria da pena. O Ministro relator Menezes Direito, porém, igualmente entendeu incabível a apreciação da matéria por parte do Supremo Tribunal Federal, porque os vícios alegados não foram previamente enfrentados pelo Superior Tribunal de Justiça, a configurar supressão de instância.

O corréu do caso anterior, também pessoa física, impetrou habeas corpus alegando inépcia da denúncia, falta de justa causa e reconhecimento de erro na dosimetria da pena

\footnotetext{
294 Até a data final deste levantamento empírico (novembro de 2010) o processo ainda aguardava o julgamento de recursos.

${ }_{295}$ HC n. 49.607/SP do Superior Tribunal de Justiça.
} 
quanto aos crimes de loteamento clandestino (artigo 50 da Lei n. 6.766/79) e de dano ambiental à unidade de conservação, arguindo:

O paciente é réu primário, conforme expressamente reconhecido na sentença de primeiro grau [...] Com todo o respeito, houve claro excesso no cálculo das penas. Os motivos adotados pela Juíza são, na verdade, elementos e circunstâncias compositivas dos próprios crimes. Eles já foram considerados na fase de fixação das margens penais pelo legislador e não podem ser valorizados novamente, na fase de aplicação judicial da reprovação penal. É inegável a incidência no proibido bis in idem. [grifos do original]. ${ }^{296}$

Quanto à pena aplicada em relação ao delito ambiental, a impetração do habeas corpus sinalizou que havia ilegalidade pelo fato de as circunstâncias do crime de loteamento clandestino terem sido usadas para o aumento da pena do crime ambiental, fixando-se a pena-base em três anos de reclusão, quando a mínima é de apenas um ano. Entretanto, esta questão não foi enfrentada formalmente sob a justificativa de supressão de instância. ${ }^{297}$ Nos autos principais, como exposto anteriormente, ainda não houve decisão definitiva de mérito ${ }^{298} \mathrm{e}$, por ora, a condenação existente encontra-se em sete anos de reclusão em regime semi-aberto, constituindo-se de três anos por infração do artigo 50, inciso I e III, e parágrafo único, incisos I e II, cumulado com o artigo 51, ambos da Lei n. 6.766/79, somados a quatro anos de reclusão por infração do artigo 40, cumulado com o artigo 53, ambos da Lei n. 9.605/98, acrescida do pagamento de 10 dias-multa.

O terceiro acórdão selecionado que se depara com a temática da sanção penal no âmbito ambiental discute a conduta de transporte de carvão vegetal sem a devida autorização administrativa. No caso concreto, o paciente, pessoa física, foi condenado a 10 meses de detenção em regime aberto e 100 dias-multa, pela prática de infração prevista no artigo 46, parágrafo único, da Lei n. 9.605/98. Essa sanção foi substituída por restritivas de direitos, consubstanciada em prestação pecuniária de doação de alimentos a entidade assistencial no valor de 20 salários mínimos, apesar de o juiz de primeira instância ter

\footnotetext{
296 Trecho do n. HC 89.735-5/SP.

297 Apesar de apresentar a alegação de não-conhecimento do habeas corpus, o Ministro Menezes Direito manifestou-se quanto ao mérito da questão, reiterando entendimento do HC anteriormente julgado: "ao contrário do que sustenta o impetrante, não vislumbro excesso na aplicação dessa pena-base que, por sinal, veio a se converter em definitiva. A exasperação da reprimenda para além do mínimo legal, com efeito, está lastreada em elementos diversos daqueles que já compõe o tipo penal, refletindo verdadeiro juízo de razoabilidade realizado pelo Magistrado a partir da valoração negativa que fez das circunstâncias judiciais previstas no artigo 59 do Código Penal. Nessa tarefa foram destacadas, com especial relevo, cinco circunstâncias: a culpabilidade (conduta dolosa que vitimou pessoas humildes, leigas e de boa fé); os motivos do crime (ganância); a conduta social e a personalidade do agente (descaso com os poderes públicos); e as conseqüências do delito (risco de desmoronamento)".

${ }^{298}$ Apelação de origem em trâmite perante o Tribunal de Justiça de São Paulo, sob o n. 990.10.303524-0.
} 
ressaltado a existência de vedação legal do artigo 44, do Código Penal, para casos de reincidência pelo mesmo crime.

O excessivo rigor da lei com condutas administrativas transformadas em crime faz com que, no caso concreto, mesmo contra legem, o magistrado transforme a condenação penal em sanção próxima da administrativa, reduzindo-a unicamente a cominação de ônus pecuniário.

Segundo argumentação do condenado, os elevados valores impostos nas penas de multa e prestação pecuniária são excessivamente onerosos e não têm outro objetivo senão o de impossibilidade do adimplemento.

O Ministro Joaquim Barbosa, ministro relator deste habeas corpus n. 84.821-4/MG, entendeu, em 23 de agosto de 2005, que a impetração não deveria prosperar. Em relação à pena de multa, argumentou que a sanção penal desta natureza não possui capacidade de gerar cerceamento da liberdade individual, porque, após o trânsito em julgado, considerase como dívida de valor, não havendo possibilidade de converter-se em prisão, nos termos do artigo 51 do Código Penal. Por essa razão e ancorado na súmula 693 do Supremo Tribunal Federal, conclui que a pena de multa não pode ser objeto de habeas corpus, instrumento que zela pela liberdade de ir e vir.

No caso anterior, em sede de habeas corpus, no Superior Tribunal de Justiça, a pena de 100 dias-multa foi alterada para 10, mesmo sem análise do conjunto probatório, com o básico raciocínio de proporcionalidade entre a pena-base da condenação imposta não fixada no máximo legal - e a pena de multa, ${ }^{299}$ que igualmente não poderia ser fixada no máximo legal, por utilizar o mesmo parâmetro do artigo 59 do Código Penal.

Quanto ao tema da pena restritiva de direitos, passível de conversão em privativa de liberdade, ${ }^{300}$ o Supremo Tribunal Federal considerou que o condenado estava em vantagem ao ter sua pena substituída por pecuniária mesmo sendo reincidente pelo mesmo delito e que esse debate exigiria reexame do conjunto probatório.

\footnotetext{
${ }^{299}$ Assim conclui o acórdão do HC n. 49.607/SP do Superior Tribunal de Justiça: "Para a fixação da pena de multa considera-se, primeiramente, o disposto no art. 59 do Estatuto Punitivo para o estabelecimento do número de dias-multa, e, em seguida, a situação econômica do sentenciado para determinar o valor de cada dia-multa. Precedente do STJ. Não obstante o reconhecimento da existência de certa discricionariedade na dosimetria da reprimenda, relativamente à exasperação das penas aplicadas - independente de sua natureza, privativa de liberdade ou de multa -, é indispensável a sua fundamentação, com base em dados concretos, em eventuais circunstâncias desfavoráveis do art. 59 do Código Penal. Se a pena-base da reprimenda corporal não foi imposta no máximo previsto em lei, tal patamar não pode ser aplicado para a pena de multa”.

${ }^{300}$ Este é o posicionamento do STF, no HC n. 85.471.
} 
Sem qualquer menção às finalidades das penas ou à adequação da sanção penal ao caso concreto, esta condenação sinaliza o interesse do Estado na reafirmação do valor meio ambiental por meio do mecanismo penal, ainda que isso implique sanções similares ou equiparadas às administrativas.

No último acórdão, o paciente, também pessoa física, foi condenado a seis meses de detenção, pena substituída por uma restritiva de direitos (consistente na restauração do local dos fatos, abandono da área embargada e demolição da construção realizada) e a 10 dias-multa, como incurso no artigo 48 da Lei n. 9.605/98, em razão de construção que impede e dificulta a regeneração natural da vegetação rasteira em unidade de conservação localizada em área de preservação permanente, às margens do Rio Jacaré-Guaçu. O debate travado no habeas corpus n. 83.437-0/SP, de relatoria do Ministro Joaquim Barbosa, tratou apenas da natureza jurídica do crime (se permanente ou instantâneo de efeitos permanentes), sem considerações sobre a pena imposta.

Da análise das decisões judiciais levantadas, extraiu-se que o Supremo Tribunal Federal não apresentou casos de condenação definitiva por Recurso Extraordinário (15 acórdãos), indicando, nos 58 acórdãos relacionados à Lei n. 9.605/98, apenas quatro habeas corpus $(6,8 \%$ do total de decisões) com sentenças condenatórias, não necessariamente transitadas em julgado.

Na leitura dos acórdãos que confirmaram a decisão de imposição de sanção penal, constata-se que o Supremo Tribunal Federal deparou-se com o restrito número de dois habeas corpus, versando sobre o mesmo processo de origem, com pena privativa de liberdade imposta pela prática de crime ambiental. Note-se que, nestes casos, a elevada pena de sete anos foi imposta em decorrência de cumulação de delitos. Se a pena imposta ao crime ambiental fosse isoladamente considerada, segundo previsão do artigo 44, I, do Código Penal, a sanção poderia ser substituída por pena restritiva de direitos, na esteira dos demais casos de condenação envolvendo a Lei n. 9.605/98.

Em regra, punem-se casos de pouca expressão lesiva, acarretando a conversão das penas em sanções equivalentes às punições administrativas. Verificou-se, no acórdão n. 84.821-4/MG, por exemplo, que o magistrado sentenciante forçou a substituição da pena privativa por prestação pecuniária, em situação expressamente vedada em lei, por não haver necessidade de tanto rigor para punição de infração administrativa de transportar carvão sem autorização do órgão competente. 
Na prática do Supremo Tribunal Federal, não se constata a temática de destruição ambiental proveniente de conduta de pessoa jurídica, ${ }^{301}$ tampouco hipóteses de poluição ambiental de peso. ${ }^{302}$ Aplica-se a Lei n. 9.605/98 aos casos menos significativos (em termos de lesividade) e aos tipos penais de menor relevância (artigos 40, 46 e 48, da Lei n. 9.605/98). E mesmo nos casos de condenação, o debate sobre as finalidades das penas nos crimes ambientais ou a discussão sobre a importância da proporcionalidade destas penas não são enfrentados nos votos dos Ministros relatores.

Para concluir a análise da jurisprudência do Supremo Tribunal Federal, merece destaque o breve exame realizado nos processos originários do STF versando sobre a Lei n. 9.605/98 (dois inquéritos e uma ação penal). Com ele, pode-se confirmar as hipóteses acima aduzidas de que os processos sobre crimes ambientais são, em muitas ocasiões, resolvidos e encerrados em primeira instância, visto que o inquérito n. $1.423-2^{303}$ teve denúncia rejeitada por inépcia; a ação penal n. 439-1 ${ }^{304}$ foi julgada improcedente por insignificância do ato em razão do bem protegido; e, por fim, o inquérito n. $2.721^{305}$ foi concluído diante da concordância do acusado com a proposta ministerial de transação penal para doação de 120 cestas básicas e 60 resmas de papel braile.

\section{C) Superior Tribunal de Justiça - STJ}

Com um mecanismo de busca similar ao do STF, a página eletrônica do STJ apresenta também sete campos ou filtros para o levantamento de dados: pesquisa livre; número; ministro; data; órgão julgador; ementa/resumo estruturado; e legislação. Por essa

\footnotetext{
${ }^{301}$ Todos os casos que versam sobre sentença condenatória tratam de pessoas físicas no pólo passivo da ação penal. Não há condenação à pessoa jurídica por crimes ambientais no Supremo Tribunal Federal.

${ }^{302}$ A ausência de aplicação do artigo 54, da Lei n. 9.605/98 gera estranheza, por ser a poluição uma das maiores preocupações dos protetores do meio ambiente. É provável que a dificuldade de aplicação do crime esteja relacionada à constatação de LUIZ REGIS PRADO (2005, p. 418): “o tipo penal é extremamente amplo e vago, com cláusulas normativas, de cunho valorativo, que estão muito aquém das exigências do princípio da legalidade em sua vertente de taxatividade-determinação da lei penal. A expressão de qualquer natureza, reveladora de um objeto indeterminado, abrange sejam quais forem a espécie e a forma de poluição, independente de seus elementos constitutivos (atmosférica, hídrica, sonora, térmica, por resíduos sólidos etc.)". Nesse sentido, quando o preceito primário é deficiente, há dificuldade de se aplicar o preceito secundário da norma penal.

303 STF, Inquérito n. 1.423-2/MG, Ministro Relator Sepúlveda Pertence, Tribunal Pleno, julgamento $18 / 11 / 2004$.

${ }^{304}$ STF, Ação Penal n. 439-1/SP, Ministro Relator Marca Aurélio, Tribunal Pleno, julgamento 12/06/2008.

${ }^{305}$ STF, Inquérito n. 2.721/DF, Ministro Relator Joaquim Barbosa, Tribunal Pleno, julgamento 08/10/2009.
} 
razão, o procedimento metodológico foi idêntico ao descrito no levantamento de dados anterior.

\begin{tabular}{|l|l|}
\hline (A) (Crimes Adj Ambientais) E (Recurso Adj Especial) & ACÓRDÃOS 37 documentos encontrados \\
\hline (B) Recurso Adj Especial E 9605 & $\begin{array}{l}\text { Apenas um julgado em que o número do Recurso } \\
\text { especial era 9605, sem relação com a lei pesquisada }\end{array}$ \\
\hline $\begin{array}{l}\text { (C) Recurso Adj Especial E Meio Adj Ambiente E } \\
\text { Crime }\end{array}$ & $\begin{array}{l}\text { ACÓRDÃOS 104 documentos encontrados } \\
23 \text { documentos relativos aos crimes ambientais não } \\
\text { estavam na lista D. }\end{array}$ \\
\hline (D) Recurso adj especial ("009605" mesmo lei).ref. & ACÓRDÃOS 109 documentos encontrados \\
\hline (E) LEI-009605 & $\begin{array}{l}\text { ACÓRDÃOS 312 documentos encontrados (inclui } \\
\text { HCs) }\end{array}$ \\
\hline
\end{tabular}

Enquanto no Supremo Tribunal Federal o número de acórdãos de Recursos Extraordinários disponíveis na página eletrônica era de 95.150, no Superior Tribunal de Justiça o número mostrou-se muito mais elevado: 233.256 acórdãos referentes a Recursos Especiais. $^{306}$

Diante desse universo mais extenso, foram encontrados, até a data final de coleta de julgados, ${ }^{307} 37$ resultados para a pesquisa (A), um para a pesquisa (B), 104 para a pesquisa (C) e 109 para a (D). Deste total de 251 acórdãos, após as associações dos acórdãos que apareciam em mais de um termo de busca, restaram 139 documentos a serem analisados.

Em uma segunda triagem, já analisando o inteiro teor dos acórdãos, 47 documentos foram expurgados por não tratarem da questão penal ambiental, o que reduziu o grupo de acórdãos referentes à matéria pesquisada a 92 Recursos Especiais.

Após detida leitura dos 92 acordãos versando sobre crimes contra o meio ambiente, julgados em sede de Recurso Especial, notou-se que apenas oito documentos tratam de recursos decorrentes de decisões condenatórias, sete encerraram o processo por absolvição ou prescrição e os demais acórdãos questionam, no decorrer da ação penal, matérias processuais de não recebimento de denúncia e de conflito de competência, conforme detalhado no gráfico abaixo.

\footnotetext{
${ }^{306}$ Como afirmado em nota anterior, o Superior Tribunal de Justiça disponibiliza, por meio de sua página eletrônica, todos os acórdãos julgados já publicados na imprensa oficial.

${ }^{307}$ Reitera-se que a busca foi realizada até outubro de 2010.
} 

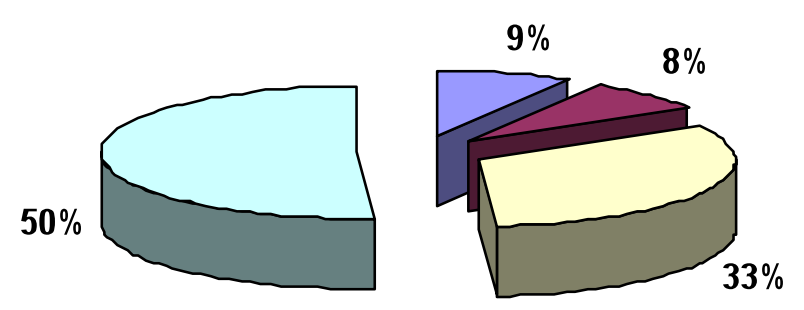

$\square$ Condenação
$\square$ Absolvição/Prescrição
$\square$ Recebimento de denúnica
$\square$ Conflito de competência

Elaboração própria

Embora a temática das penas também seja tratada de forma tímida pelo Superior Tribunal de Justiça, merecem análise os oito acórdãos que enfrentaram a questão da condenação em crimes ambientais.

O primeiro caso analisado no STJ referente à condenação por crime ambiental, em acórdão proferido pelo Ministro Gilson Dipp, no Recurso Especial n. 680.007/SC, teve julgamento datado de 15 de fevereiro de 2005, ou seja, seis anos após a edição da Lei n. 9.605/98.

No processo em análise, o acusado foi condenado, em primeira instância, ${ }^{308}$ pela prática de pesca com linha de mão em local interditado e protegido pelo IBAMA, nos termos do art. 34 da Lei n. 9.605/98, à pena de dois anos de detenção, em regime aberto, e ao pagamento de 30 dias-multa, sendo a privativa de liberdade substituída por prestação de serviços à comunidade ou a entidades públicas, à razão de uma hora de tarefa gratuita por dia de condenação e prestação pecuniária no valor de $\mathrm{R} \$ 10.000,00$. Na aplicação da sanção, o juiz considerou a agravante do art. 15, II, alínea $e$, da mesma lei, por se tratar de infração que atingiu áreas de unidade de conservação.

A pena foi diminuída, em sede de apelação no Tribunal Regional Federal da $4^{\mathrm{a}}$ Região, ${ }^{309}$ para um ano e três meses de detenção, pela fixação da pena-base no mínimolegal; e ao pagamento de 30 dias-multa. Quanto às penas restritivas de direitos, houve modificação da penalidade pecuniária substitutiva para $\mathrm{R} \$ 6.250,00$, mantendo-se a

308 Processo n. 2001.72.00.007080-3, Juiz Federal Julio Guilherme Berezoski Shattschneider, da Vara Ambiental Federal de Florianópolis.

${ }^{309}$ Apelação n. 2001.72.00.007080-3/SC, Desembargador Federal Relator Luiz Fernando Wowk Penteado, $8^{\mathrm{a}}$ Turma. 
prestação de serviços à comunidade, nos mesmos termos da sentença condenatória recorrida.

No Superior Tribunal de Justiça, o Recurso Especial n. 680.007/SC, exclusivamente da defesa, contestou a ausência de apreciação de provas produzidas pela defesa $^{310}$ e a aplicação da agravante do art. 15 da Lei n. 9.605/98, sob o argumento de bis in idem. ${ }^{311} \mathrm{O}$ recurso foi parcialmente conhecido e desprovido, mantendo-se a pena aplicada no Tribunal a quo.

Ainda que o debate sobre a aplicação da agravante tenha gerado uma discussão sobre a aplicação da pena, esta se reduziu tão-somente à argumentação de subsunção normativa, sem qualquer referência às finalidades das penas ou análise de proporcionalidade entre a sanção e a conduta.

A Ministra Laurita Vaz manteve o mesmo posicionamento no Recurso Especial n. 693.261/SC, que trata de infração criminal decorrente da construção de casa de praia, sem autorização legal, em área litorânea de preservação permanente.

Condenado pela prática do crime do art. 63, cumulado com a agravante do art. 15, inciso II, alínea $h,{ }^{312}$ ambos da Lei n. 9.605/98, à pena de 1 ano e 2 meses de reclusão, em regime aberto, substituída por restritiva de direitos (na modalidade de prestação de serviço à comunidade e prestação pecuniária), o recorrente, em Recurso Especial, alegou erro de tipo e afastamento da circunstância que agravou a pena, tendo em vista que a construção não foi iniciada em domingo ou feriado.

O Recurso Especial, entretanto, não foi sequer conhecido, porque se entendeu que a demanda de ausência de dolo exigiria reexame do conjunto fático-probatório e, por isso, não se coadunaria com a limitação imposta pela súmula 07 do Superior Tribunal de Justiça. Além disso, reafirmou-se a incidência da majorante do art. 15, inciso II, $h$, da Lei $n$. 9.605/98, de modo que o debate sobre a pena restou prejudicado pelo não conhecimento do recurso. Entretanto, constata-se que configura a segunda incidência no Superior Tribunal

\footnotetext{
${ }^{310}$ Esta argumentação foi afastada pelo STJ, por entender que haveria necessidade de ingressar no contexto probatório dos autos, inviável nos termos da súmula 07/STJ.

311 Nesta parte, o Recurso Especial foi conhecido, mas negou-se provimento por entender que "tendo o recorrente cometido o delito em local interditado e protegido pelo IBAMA restou incurso nas penas do art. 34 da Lei ambiental e, em se tratando de fato ocorrido em área especialmente protegida (Unidade de Conservação), deve ser mantida a agravante do art. 15, II, "e", da mesma lei, eis que os conceitos são distintos." (nos termos do acórdão).

${ }^{312}$ Art. 15 da Lei n. 9.605/98. São circunstâncias que agravam a pena, quando não constituem ou qualificam o crime: [...] II - ter o agente cometido a infração: [...] h) em domingos ou feriados.
} 
de Justiça em que há pena privativa de liberdade substituída por restritiva de direitos, cumulada com multa.

O terceiro acórdão analisado poderia ser paradigmático a respeito das penas aplicáveis às pessoas jurídicas, não fosse o resultado obtido. O Superior Tribunal de Justiça, no Recurso Especial n. 889528/SC, julgado pela 5 $5^{\text {a }}$ Turma, em 17 de abril de 2007, apreciou processo penal em que a empresa ré era a única que figurava no pólo passivo da ação. O processo foi cindido em relação ao corréu, prosseguindo apenas em relação à empresa ré. Concluída a instrução, a recorrida foi condenada, nos termos da denúncia, ao pagamento de 130 dias-multa - pela somatória de 100 dias-multa pela prática do artigo 54, $\S 2^{\circ}$, inciso III, e 30 dias multa pelo artigo 60, ambos da Lei n. 9.605/98 -, cujo valor unitário equivaleria a um salário mínimo vigente à época dos fatos.

Segundo consta, a empresa emitia óleos e graxas em um córrego afluente do Rio Guamerim, em Santa Catarina, gerando poluição hídrica por derivados de hidrocarbonetos, em índices fora dos permitidos, na água captada para consumo da população de Descanso/SC. Ademais, desenvolvia atividade potencialmente causadora de degradação ambiental ao manter uma rampa de lavagem e lubrificação, sem a devida licença ambiental emitida pelos órgãos competentes.

Em segundo grau de jurisdição, a sentença condenatória foi revista, com base na imputação de responsabilidade penal à pessoa jurídica, afastando a condenação da empresa. O Tribunal de Justiça da Santa Catarina se manifestou da seguinte maneira:

Dessarte, de tudo o que aqui ficou dito, portanto, conclui-se que o
instituto da responsabilidade penal da pessoa jurídica não pode ser
introduzido no sistema brasileiro sem que este, especificamente, passe
por uma adaptação, pois está solidamente alicerçado em postulados que
não o admitem.
Isto não significa dizer que as pessoas coletivas não devam sofrer punição
pelos atos assim considerados delituosos no exercício de suas atividades.
Devem ser punidas, sim, mormente em nosso tempo, onde os novos tipos
de criminalidade surgem, onde as vítimas não são, no mais das vezes,
determinadas, mas, sim, determináveis. Porém, os meios sancionatórios
não devem estar previstos, necessariamente, na esfera penal, pois o
Direito penal atua sempre como ultima ratio, o que não é desejável na
solução desses conflitos de massa provocados pelas pessoas coletivas.
Para isso, mais eficaz e efetivo seria um direito administrativo
sancionador, a par de outras sanções civis cumuláveis, conforme a
gravidade do caso. ${ }^{313}$

${ }^{313}$ Tribunal de Justiça de Santa Catarina, Apelação Criminal n. 2006.002010-3, Desembargador relator Irineu João da Silva, Segunda Câmara Criminal, julgamento 21/02/2006. 
O processo foi anulado e a denúncia rejeitada, nos termos do artigo 43, III, do Código de Processo Penal pela Segunda Câmara Criminal do Tribunal de Justiça de Santa Catarina. Diante desta decisão, o representante do Ministério Público apresentou Recurso Especial para o Superior Tribunal de Justiça.

No STJ, a Quinta Turma desconstituiu o acórdão a quo, admitindo-se a responsabilidade penal da pessoa jurídica em crimes ambientais, com a condição de que haja imputação simultânea da empresa e da pessoa física que atua em seu nome ou em seu benefício, como forma de não comprometer a apuração do elemento subjetivo necessário no Direito Penal. Após retorno dos autos ao TJSC, foi declarada extinta a punibilidade da empresa, pelo reconhecimento da prescrição da pretensão punitiva do Estado, na forma superveniente, prejudicando o reexame do mérito do recurso segundo determinado pelo Superior Tribunal de Justiça.

Ressalta-se que, após a extinção da punibilidade deste caso, em nenhuma outra situação foi observada imputação exclusiva à pessoa jurídica por crime ambiental no Superior Tribunal de Justiça, tampouco hipótese de imputação e condenação pela prática de delito de poluição contra o meio ambiente, nos termos do art. 54, da Lei n. 9.605/98.

Outro acórdão que trata de sentença condenatória em crimes ambientais foi proferido no Recurso Especial n. 867938/PR, no julgamento de 22/05/2007. Em seu relatório, o Ministro Felix Fischer, ao analisar a pena aplicada pela prática de destruir floresta de preservação permanente e de dificultar regeneração natural de florestas (artigos 38, caput e 48, ambos da Lei n. 9.605/98), deu parcial provimento ao recurso por entender que haveria incidência da agravante consistente na obtenção de vantagem pecuniária (artigo, 15, II, $a$, da Lei n. 9.605/98), mas não encontraria adequação aos fatos as agravantes de emprego de fraude e abuso de confiança (artigo 15, II, $n$ da Lei n. 9.605/98). Assim, a condenação penal de primeira instância - de 4 anos, 3 meses e 15 dias em regime semi-aberto, e 210 dias-multa $^{314}$-, alterada em segunda instância para extinção da

\footnotetext{
${ }^{314}$ Segundo relatório da Apelação Criminal (Tribunal de Justiça do Paraná, Apelação Criminal n. 279571-5, Desembargador Relator Laertes Ferreira Gomes, Quarta Câmara Criminal, julgamento 21 de julho de 2005), a sentença de primeiro grau foi assim fixada: "Para o delito destruição de floresta de preservação permanente, fixou a pena-base em 01 (um) ano e 6 (seis) meses de detenção e 100 (cem) dias-multa, ao valor unitário de 1/10 (um décimo) do salário mínimo vigente na época dos fatos, Pela reincidência agravou a pena em 4 (quatro) meses de detenção e 10 (dez) dias-multa e, pelas agravantes específicas, majorou a pena em 4 (quatro) meses e 15 (quinze) dias de detenção e 11 (onze) dias-multa para cada uma das três agravantes, tornando a pena em definitivo na razão de 2 (dois) anos 11 (onze) meses e 15 (quinze) dias de detenção e 143 (cento e quarenta e três) dias-multa.

Para o delito de "impedir ou dificultar a regeneração natural de florestas", fixou a pena base em 7 (sete) meses de detenção e 40 (quarenta) dias-multa, majorando-a em 2 (dois) meses de detenção e 6 (seis) dias-
} 
punibilidade pela prescrição em relação ao delito previsto no art. 48 da Lei n. 9.605/98 e substituição da pena restante por restritiva de direitos e multa, ${ }^{315}$ foi definitivamente fixada em 1 ano e 3 meses de detenção e 70 dias-multa, sendo a pena corporal substituída por prestação de serviços à comunidade durante o mesmo período da pena privativa de liberdade substituída e multa.

A Ministra Maria Thereza de Assis Moura também manteve decisão condenatória ambiental de substituição de pena privativa de liberdade por pena restritiva de direitos em acórdão proferido no Recurso Especial n. 933356/MG, julgado na Sexta Turma, em 18/12/2007. Em seu relatório, a ministra ressaltou as discussões jurídicas existentes no âmbito do Direito Penal ambiental "sobretudo no que se refere à configuração dos tipos penais nela inscritos. Dentro da celeuma que se edificou, há um aspecto que suplanta em importância todos os outros porventura existentes, sendo o ponto de maior divergência entre os princípios penais de garantia do cidadão e as novas tendências dos denominados direitos de terceira geração, como o direito difuso ao meio ambiente”. O Recurso Especial, que tratava de condenação por incêndio provocado na Serra do Cipó/MG (artigo 41 da Lei n. 9.605/98), não foi conhecido, por se entender que haveria necessidade de exame probatório vedado pela súmula 7 do STJ, o que acarretou a confirmação do acórdão a quo que condenou o recorrente, pessoa física, a 2 anos e 4 meses de reclusão, somado a pena de multa, havendo substituição por duas penas restritivas de direitos.

Destaca-se que, embora tenha havido julgamento do Recurso Especial, o processo ainda está pendente de decisão sobre agravo de instrumento contra decisão denegatória de

multa em face a reincidência e, em 7 (sete) meses de detenção e 21 (vinte e um) dias-multa em razão das agravantes específicas dos artigos 15, II, alíneas 'a', 'c' e ' $n$ ' da Lei 9.605/1998, perfazendo a pena definitiva de 1 (um) ano e 4 (quatro) meses de detenção e 67 (sessenta e sete) dias-multa.

Pelo concurso material, a pena final totalizou em 4 (quatro) anos, 3 (três) meses e 15 (quinze) dias de detenção e 210 (duzentos e dez) dias-multa, no valor unitário de 1/10 (um décimo) do salário mínimo vigente à época dos fatos.

Em razão da reincidência, do quantum da pena e em face as circunstâncias judiciais, o regime fixado foi o semi aberto. Em obediência ao que dispõe o artigo 20 da Lei 9.605/1998, a sentença fixou o valor mínimo de reparação dos danos provocados pela infração em $\mathrm{R} \$ 6.000,00$ (seis mil reais)."

${ }^{315}$ Segundo relatório da Apelação Criminal (Tribunal de Justiça do Paraná, Apelação Criminal n. 279571-5, Desembargador Relator Laertes Ferreira Gomes, Quarta Câmara Criminal, julgamento 21 de julho de 2005), a decisão de segundo grau foi fixada nos seguintes termos: "Destarte, fixo a pena em definitivo para o delito descrito no artigo 38 e artigo 15, II, 'c' da Lei 9605/98, em 1 (um) ano 7 (sete) meses e 15 (quinze) dias de detenção e 81 (oitenta e um) dias-multa, na razão de 1/10 (um décimo) do salário mínimo vigente na época dos fatos. Para o delito descrito no artigo 48 da Lei 9605/1998, fixo a pena base em 6 (seis) meses e 15 (quinze) dias de detenção e 30 (trinta) dias-multa, afastando, igualmente a majoração em razão dos maus antecedentes e em face a reincidência.

Em razão da agravante específica capituladas no artigo 15, alínea 'c' da Lei 9605/98, aumento a pena em 2 (dois) meses e 10 (dez) dias de detenção e 7 (sete) dias-multa, afastando, pelas razões exposadas, as demais agravantes específicas, quedando-se a pena em definitivo em 8 (oito) meses 25 (vinte e cinco) dias de detenção e 37 (trinta e sete) dias-multa." 
seguimento de Recurso Extraordinário (STF, AI n. 710392), restando sobrestados os autos principais sem decisão transitada em julgado. ${ }^{316}$

A decisão seguinte destoa de todos os demais acórdãos apreciados, em razão da elevada pena aplicada a pessoas físicas em primeira instância, pela prática de atos subsumidos aos artigos 55, caput, da Lei n. 9.605/98 e $2^{\circ}$, caput, da Lei n. 8.176/91: 9 anos, 3 meses e 30 dias de detenção e pagamento de 758 dias-multa para um dos acusados e 9 anos de detenção, em regime inicial fechado, bem como ao pagamento de 709 diasmulta para outros três acusados; e 8 anos e 3 meses de detenção, em regime inicial fechado, bem como ao pagamento de 621 (seiscentos e vinte e um) dias-multa ao último condenado. Destaca-se que o processo principal ainda está em andamento perante o Tribunal Regional Federal da $3^{\mathrm{a}}$ Região, ${ }^{317}$ sendo que o recurso apreciado no Superior Tribunal de Justiça questiona acórdão proferido nos autos de habeas corpus (TRF3, HC n. 18.817), ${ }^{318}$ a respeito de questão processual sobre o direito de recorrer em liberdade.

Em sede de apelação e embargos de declaração no Tribunal Regional Federal da $3^{\mathrm{a}}$ Região, a sentença foi alterada, para que a conduta de extração ilegal de areia sem licença dos órgãos competentes de fiscalização fosse punida com menor rigor. Entretanto, não há decisão transitada em julgado podendo haver possibilidade de alteração do acórdão que fixou a pena mais elevada em 5 anos e 10 meses de detenção ${ }^{319}$ (com cumprimento inicial

316 Tribunal Regional Federal da $1^{\text {a }}$ Região, Apelação Criminal n. 2000.38.00.018570-6. Desembargador Federal relator Cândido Ribeiro. $\quad$ Terceira Turma. $<\mathrm{http}$ ://www.trf1.jus.br/Processos/ProcessosTRF/>. Acesso em 02.12.2010.

317 Tribunal Regional Federal da $3^{\mathrm{a}}$ Região. Apelação Criminal n. 2000.61.10.000124-6, Desembargador Federal relator Vesna Kolmar. Primeira Seção. Disponível em <http://www.trf3.jus.br>. Acesso em 02.12 .2010 .

${ }^{318}$ O número do habeas corpus mencionado no relatório do Recurso Especial não segue o padrão de busca do Tribunal Regional Federal da $3^{\mathrm{a}}$ Região; por essa razão não foi possível ter acesso a seu inteiro teor.

${ }^{319}$ Segundo acórdão do Tribunal Regional Federal da $3^{\text {a }}$ Região, na apelação Criminal n. 2000.61.10.0001246: "O acusado Jorge praticou, por três vezes, o delito tipificado no art. 55 da Lei n. 9.605/98 e no $2^{\circ}$ da Lei n. $8.176 / 91$, em concurso formal, de modo que é de se aplicar a mais grave das penas, ou seja, a do delito do art. $2^{\circ}$ da Lei n. 8.176/91, aumentada em 1/6 (um sexto), nos termos do art. 70, caput, do Código Penal.

Considerados os critérios estabelecidos no art. 59 do Código Penal, em especial a sua culpabilidade, dada condição de empresário, os motivos do crime, tendo em vista a ganância e a busca pelo lucro fácil, a personalidade voltada a prática de crimes, dado que,apesar de ter sido autuado uma vez pela autoridade administrativa, continuou a delinqüir, demonstrando descaso com a Justiça, e as conseqüências do crime, considerado o dano efetivo ao meio ambiente, conforme explanado nos tópicos acima, fixo a pena-base acima do mínimo legal, em 1 (um) ano e 8 (oito) meses de detenção e 14 (catorze) dias-multa. Ausentes agravantes ou atenuantes genéricas. Aumento a pena em 1/6 (um sexto), nos termos do art. 70 do Código Penal, perfazendo o total de 1 (um) ano, 11 (onze) meses e 10 (dez) dias de detenção e 16 (dezesseis) diasmulta, a qual torno definitiva.

Mantenho o valor de cada dia-multa em 1/3 (um terço) do salário mínimo vigente ao tempo dos fatos, devidamente corrigido, considerada a ausência de recurso da acusação, o que impede o aumento da pena.

Não ocorreu a prescrição da pretensão punitiva estatal em relação a esses delitos. Tendo em vista que acusado Jorge praticou o crime em três oportunidades $(08.10 .97,18.09 .98$ e 06.07.99), deve ser aplicada a regra do concurso material prevista no art. 69, caput, do Código Penal. 
no regime semi-aberto) e o pagamento de 48 dias-multa. A pena imposta neste caso não pode ser considerada para o perfil das sanções penais aplicadas neste estudo, visto estar sujeita a modificações.

No penúltimo acórdão analisado, novamente a temática da responsabilidade penal da pessoa jurídica surgiu na pauta. No Recurso Especial n. 989089/SC, de relatoria do Ministro Arnaldo Esteves Lima, julgado em 18/08/2009, discute-se a possibilidade de a empresa figurar no pólo passivo da ação penal. O Superior Tribunal de Justiça tem se posicionado pela possibilidade, "desde que haja a imputação simultânea do ente moral e da pessoa física que atua em seu nome ou em seu benefício, uma vez que não se pode compreender a responsabilização do ente moral dissociada da atuação de uma pessoa física, que age com elemento subjetivo próprio". 320

Em todos os acórdãos analisados nos tribunais superiores, esta foi a primeira e única decisão que confirmou uma sanção penal imposta à pessoa jurídica, com trânsito em julgado. No caso em tela, as pessoas física e jurídica foram denunciadas pela prática dos crimes previstos nos artigos 39, 46, parágrafo único, 51 e 60 da Lei n. 9.605/98 c.c 65, III, "d", 69 e 70 do Código Penal, por guardar e ter em depósito madeira nativa, sem licença válida e necessária outorgada pela autoridade competente. Em primeira instância, o magistrado reconheceu a extinção da punibilidade relativamente aos delitos dos artigos 51 e 46, parágrafo único, da Lei n. 9.605/98, pela ocorrência da prescrição de pretensão punitiva. Contudo, condenou os imputados às penas de 2 anos e 2 meses de detenção e 40 dias-multa à pessoa física e 26 contribuições mensais equivalentes a meio salário mínimo e 40 dias-multa à pessoa jurídica pelo cometimento dos delitos definidos nos artigos. 39, 46, parágrafo único, e 51, todos da Lei n. 9.605/98. E, ao fim, substituiu a pena privativa de liberdade infligida à pessoa física por duas restritivas de direitos, consistentes em prestação de serviços à comunidade e prestação pecuniária.

Em segundo grau, o Tribunal de Justiça de Santa Catarina afastou a possibilidade de responsabilidade penal da pessoa jurídica, enunciando que o legislador previu essa

Desse modo, a pena resulta em 5 (cinco) anos e 10 (dez) meses de detenção e o pagamento de 48 (quarenta e oito) dias-multa. Determino o regime semi-aberto para início do cumprimento da pena privativa de liberdade, em atenção ao art. $33, \S 2^{\circ}, b$, do Código Penal.

Ausente o requisito do art. 44, I, do Código Penal, deixo de substituir a pena privativa de liberdade pela pena restritiva de direitos."

${ }^{320}$ Superior Tribunal de Justiça. Recurso Especial n. 989089/SC. Ministro Relator Arnaldo Esteves Lima. Quinta Turma. Disponível em <http://www.stj.jus.br>. Acesso em 15.11.2010. 
forma de imputação sem, de fato, instituí-la corretamente. ${ }^{321}$ Sobre a questão das penas aplicáveis à empresa, o acórdão a quo afastou a existência de qualquer finalidade que justificasse a imposição da sanção penal, contentando-se com a atuação das outras esferas de proteção do meio ambiente.

A respeito da pena, as idéias de prevenção geral, prevenção especial, reafirmação do ordenamento jurídico e ressocialização não teriam sentido em relação às pessoas jurídicas? A pena não pode ser dirigida, em sentido estrito, às pessoas jurídicas no lugar das pessoas físicas que atrás delas se encontram, porque conceitualmente implica uma ameaça psicológica de imposição de um mal para o caso de quem delinqüir e não se pode imaginar que a pessoa jurídica possa sentir o efeito de cominação psicológica alguma.

Em verdade o princípio da personalidade da pena - nenhuma pena passará da pessoa do condenado (art. $5^{\circ}, \mathrm{XLV}$, da CF) - tradicionalmente enraizado nos textos constitucionais brasileiros, impõe que a sanção penal recaia exclusivamente sobre os autores materiais do delito e não sobre todos os membros da corporação (v.g., operários, sócios minoritários etc.), o que ocorreria caso se lhe impusesse uma pena. Não há lugar aqui para outra interpretação senão a que liga a responsabilidade penal à realização de um comportamento próprio, sendo a responsabilidade pessoal sempre e exclusivamente de ordem subjetiva. [...]

Apesar disso, faz-se mister a proteção jurídica ao meio ambiente, há tempos agredido continuamente, sob pena de legarmos às futuras gerações um planeta degradado, destituído de recursos essenciais à sobrevivência humana. Contudo, constituindo-se o Direito Penal na ultima ratio, efetivamente não se vislumbra a necessidade de penalização das pessoas jurídicas, cuja responsabilização nas esferas civil e administrativa afiguram-se suficientes à prevenção e reparação dos danos ambientais. ${ }^{322}$

Quanto à pena aplicada à pessoa física, igualmente como ocorreu nos demais casos apreciados, houve substituição da pena privativa de liberdade - de um ano de detenção pelo crime descrito no artigo 39, porque os delitos capitulados nos artigos 51 e 46, parágrafo único, todos da Lei n. 9.605/98, já estavam prescritos - por restritiva de direitos,

\footnotetext{
321 Tribunal de Justiça de Santa Catarina. Recurso Criminal em Apelação Criminal n. 2006.030339-9. Desembargador Relator Sérgio Paladino. Segunda Câmara Criminal. Disponível em <http://www.tj.sc.gov.br>. Acesso em 5.12.2010: Diante disso, parte considerável da doutrina pátria consolidou a orientação consoante a qual o legislador de 1998, de forma simplista, nada mais fez do que enunciar a responsabilidade penal da pessoa jurídica, cominando-lhe penas, sem lograr, contudo, instituí-la completamente. Isso significa não ser ela passível de aplicação concreta e imediata, pois faltam-lhe instrumentos hábeis e indispensáveis para a consecução de tal desiderato. Não há como, em termos lógicojurídicos, romper um princípio fundamental como o da irresponsabilidade criminal da pessoa jurídica, ancorado solidamente no sistema de responsabilidade de pessoa natural, sem fornecer, em contrapartida, elementos básicos e específicos conformadores de um subsistema ou microssistema de responsabilidade penal, restrito e especial, inclusive com regras processuais próprias (PRADO, 2001).

${ }_{322}$ Tribunal de Justiça de Santa Catarina. Recurso Criminal em Apelação Criminal n. 2006.030339-9. Desembargador Relator Sérgio Paladino. Segunda Câmara Criminal. Disponível em $<$ http://www.tj.sc.gov.br>. Acesso em 5.12.2010.
} 
mas limitada em somente uma de prestação pecuniária, após suprimir a prestação de serviços à comunidade.

O Superior Tribunal de Justiça, ao restabelecer a sentença condenatória em relação à empresa, afirmou que ela foi "condenada à pena de 2 anos e 2 meses de prestação de serviços à comunidade na forma de 26 contribuições mensais equivalentes a meio salário mínimo" pela prática dos delitos previstos nos artigos “39, 46, parágrafo único, 51 e 60 da Lei n. 9.605/98 c.c 65, III, "d", 69 e 70 do Código Penal". Todavia, não se ateve à prescrição dos delitos anteriormente reconhecidos à pessoa física. Após o retorno dos autos à origem, houve trânsito em julgado da decisão.

Para concluir os acórdãos selecionados no Superior Tribunal de Justiça, destaca-se o Recurso Especial n. 905484/RO, julgado mais recentemente, em 04/02/2010, sob a relatoria do Ministro Arnaldo Esteves Lima. Neste caso, à distinção dos demais, houve a impossibilidade de substituição da pena privativa de liberdade por restritiva de direitos, porque considerados ausentes os requisitos exigidos pela legislação, ${ }^{323}$ de modo a impor regime fechado para o cumprimento da pena de dois anos de reclusão por extração indevida de madeira, prevista como crime no artigo 40, parágrafo $1^{\circ}$, da Lei n. 9.605/98.

Sem embargo tenha sido objeto do Recurso Especial o pedido de substituição da pena por restritiva de direitos, o Superior Tribunal de Justiça confirmou a imposição de da privativa de liberdade, com base no posicionamento do Ministério Público Federal:

[...] analisando concretamente a existência dos requisitos previstos no inciso II [do art. $7^{\circ}$, da Lei n. 9.605/98], o recorrente não tem direito ao benefício, pois sua personalidade voltada para o crime indica que a substituição não será suficiente para reprovação e prevenção do crime. Tal conclusão mostra-se ainda mais acertada quando se considera que já foi beneficiado pela transação penal em outro crime contra o meio

323 Tribunal de Justiça de Rondônia. Apelação Criminal n. 1006687-03.2004.822.0501. Desembargadora Relatora Zelite Andrade Carneiro. Primeira Câmara Criminal. Disponível em <http://www.tjro.jus.br>. Acesso em 5.12.2010: “A culpabilidade é inequívoca na medida em que tinha consciência da conduta criminosa; possui antecedentes em crimes ambientais (fls. 147/148), porém é primário. A personalidade volta-se para a prática delituosa, visto que responde a outros processos da mesma natureza, o que mostra ter frieza na destruição do meio ambiente.

As circunstâncias do crime não lhe favorecem, uma vez que concorreu para a retirada ilegal da madeira. As consequências do fato são graves, eis que causou malefício ao meio ambiente; os motivos do crime foram a cupidez e a ambição pelo lucro fácil com a revenda da madeira.

Por tais razões, fixo a pena um pouco acima do mínimo legal, ou seja, em 2 anos de reclusão, considerando sobretudo o alto grau de censurabilidade com que se houve o réu, bem assim as consequências do crime produzidas ao meio ambiente cuja extensão é imensurável, considerando que uma árvore do porte das derrubadas demorará cerca de cinquenta anos para atingir aquele mesmo porte. Inexistem circunstâncias agravantes ou atenuantes, assim como causas de aumento ou diminuição da pena, de modo que a torno definitiva" 
ambiente e pela suspensão do processo nos autos n. 501.1998.003093-1 (fl. 147), voltando a ser denunciado em outras duas oportunidades.

O recorrido, apesar de ser primário e ter aceitado em outras oportunidades os benefícios da transação penal e da suspensão condicional do processo, previstos na Lei n. 9.099/95 - que não implicam juízo de mérito sobre a culpabilidade - viu-se tolhido do direito de substituição da pena de prisão, porque pareceu insuficiente para as funções preventivo e repressivo da pena.

No cômputo final dos oito acórdãos examinados em profundidade, desconsiderando as duas decisões que ainda não têm decisão final condenatória com trânsito em julgado, quatro acórdãos confirmaram a substituição da pena privativa de liberdade para restritiva de direitos. Isto representa menos de $5 \%$ dos acórdãos versando sobre a crimes ambientais da Lei n. 9.605/98, do total de 92 decisões. O quadro configura-se ainda mais tímido nas hipóteses de imposição da pena mais gravosa. Apenas um acórdão manteve a prisão e o regime fechado para o cumprimento da condenação.

Nota-se que as finalidades das penas nos crimes ambientais, mesmo diante de suas peculiaridades, não são utilizadas como fundamento na aplicação da sanção no caso concreto, sendo mencionadas raramente, de forma tangencial e superficial, nos exatos termos da legislação.

No tocante ao perfil dos conflitos julgados no Superior Tribunal de Justiça, verifica-se a preponderância de demandas destinadas às pessoas físicas (74 acórdãos), restando poucos processos com a pessoa jurídica no pólo passivo da ação penal (oito acórdãos somente com pessoa jurídica e 10 com dupla imputação) e, ainda, uma única condenação à pessoa jurídica (Recurso Especial n. 989089/SC).

\section{Réu (92 Recursos Especiais)}
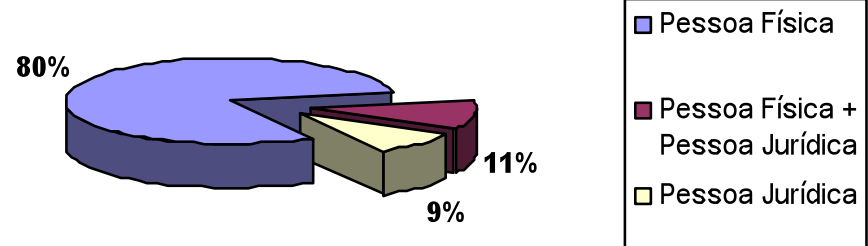


\section{D) Análise de resultados}

A pesquisa empírica, baseada nos julgados do Supremo Tribunal Federal e Superior Tribunal de Justiça, dentro das limitações apresentadas na metodologia, demonstra que o problema do meio ambiente não está sendo resolvido pela aplicação do Direito Penal ambiental nos tribunais superiores. Após quase 13 anos de vigência da norma, observa-se que a Lei de Crimes Ambientais, se inicialmente trouxe algum indicativo de instrumento apto a solucionar o problema da degradação e poluição do meio ambiente, nos dias atuais aponta para o sentido oposto.

$\mathrm{Na}$ análise da incapacidade estrutural para a produção de efeitos instrumentais, constata-se que a Lei de Crimes Ambientais tem sido aplicada nos tribunais superiores, mas de forma tímida e questionável. Tímida porque o número de ocorrências referentes à Lei n. 9.605/98 no STF e STJ é baixo (58 no primeiro e 312 no segundo), e ainda menor se consideradas as decisões meritórias sobre crimes ambientais (15 Recursos Extraordinários e 92 Recursos Especiais). Questionável porque a predominância de acórdãos versando sobre questões processuais indica que a redação legislativa gera dúvidas sobre a aplicação da lei, seja na adequação da denúncia para o início da ação penal, seja na definição do órgão competente para o processamento do feito. O processo, nestes termos, acaba por se transformar em meio de coerção, diante da valorização da intimidação processual e da carência de resultados condenatórios. Nesse sentido, a pesquisa concluiu que as decisões condenatórias são muito pouco expressivas (nenhum RE e quatro HCs no STF e oito RESPs no STJ - nem todas com trânsito em julgado), e limitadas a um grupo restrito de tipos penais, embora a Lei n. 9.605/98 apresente 55 crimes distintos. ${ }^{324}$

Analisando apenas os Recursos Extraordinários e os Recursos Especiais, verifica-se que alguns tipos penais nunca foram objeto de processo penal e que outros, embora tenham gerado um processo, não levaram a qualquer condenação. Esses dados podem ser indicativos de que parte da Lei n. 9.605/98 já tenha nascido simbólica, diante da impossibilidade e inviabilidade de aplicação da norma no caso concreto e que, talvez, caiba uma reflexão sobre a limitação do âmbito penal a um número menor de imputações. O quadro abaixo apresenta, no eixo vertical, todos os tipos penais existentes na Lei de Crimes Ambientais e, no eixo horizontal, a incidência processual dos tipos nos Recursos

\footnotetext{
${ }^{324}$ Neste caso, consideram-se apenas os tipos simples previstos pelo texto legal, sem a consideração dos tipos mistos, acrescidos de causas de aumento ou diminuição de pena.
} 
Extraordinários, nos Recursos Especiais, e os raros casos de condenação em sede de Recurso Especial (“STJ cond.”).

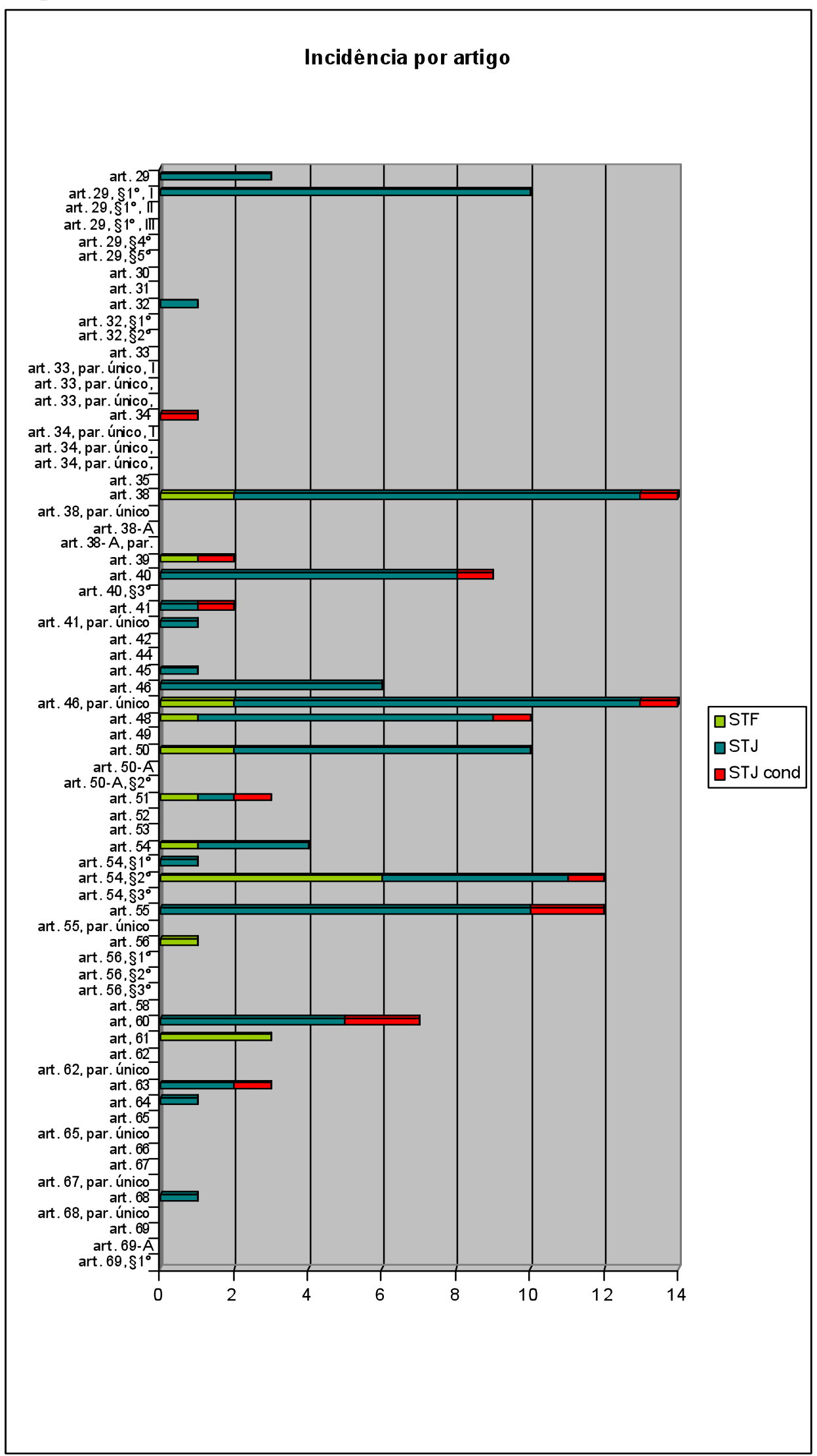


Dessa forma, tem-se a completa ausência de aplicação, nos tribunais superiores, dos artigos $29, \S 1^{\mathrm{o}}$, II, III, $\S 4^{\mathrm{o}}, \S 5^{\mathrm{o}}, ;^{325} 30 ;^{326} 31 ;^{327} 32, \S 1^{\mathrm{o}}$ e $\S 2^{\mathrm{o}} ;{ }^{328} 33$, caput e parágrafo único; ${ }^{329} 34$, parágrafo único, I, II e III; ${ }^{330} 35 ;{ }^{331} 38$, parágrafo único; ${ }^{332} 38-\mathrm{A}$, caput e parágrafo único; $;^{333} 40, \S 3^{\mathrm{o}} ;^{334} 40-\mathrm{A}, \S 1^{\mathrm{o}}, \S 2^{\mathrm{o}}$ e $\S 3^{\mathrm{o}} ;^{335} 42 ;^{336} 44 ;^{337} 49 ;^{338} 50-\mathrm{A}$, caput e

325 Art. 29. Matar, perseguir, caçar, apanhar, utilizar espécimes da fauna silvestre, nativos ou em rota migratória, sem a devida permissão, licença ou autorização da autoridade competente, ou em desacordo com a obtida: II - quem modifica, danifica ou destrói ninho, abrigo ou criadouro natural; III - quem vende, expõe à venda, exporta ou adquire, guarda, tem em cativeiro ou depósito, utiliza ou transporta ovos, larvas ou espécimes da fauna silvestre, nativa ou em rota migratória, bem como produtos e objetos dela oriundos, provenientes de criadouros não autorizados ou sem a devida permissão, licença ou autorização da autoridade competente.

$\S 4^{\circ}$ A pena é aumentada de metade, se o crime é praticado: I - contra espécie rara ou considerada ameaçada de extinção, ainda que somente no local da infração; II - em período proibido à caça; III - durante a noite; IV - com abuso de licença; V - em unidade de conservação; VI - com emprego de métodos ou instrumentos capazes de provocar destruição em massa. $\S 5^{\circ}$ A pena é aumentada até o triplo, se o crime decorre do exercício de caça profissional.

${ }^{326}$ Art. 30. Exportar para o exterior peles e couros de anfíbios e répteis em bruto, sem a autorização da autoridade ambiental competente.

${ }^{327}$ Art. 31. Introduzir espécime animal no País, sem parecer técnico oficial favorável e licença expedida por autoridade competente

${ }^{328}$ Art. $32 . \S 1^{\circ}$ Incorre nas mesmas penas quem realiza experiência dolorosa ou cruel em animal vivo, ainda que para fins didáticos ou científicos, quando existirem recursos alternativos. $\S 2^{\circ}$ A pena é aumentada de um sexto a um terço, se ocorre morte do animal.

${ }^{329}$ Art. 33. Provocar, pela emissão de efluentes ou carreamento de materiais, o perecimento de espécimes da fauna aquática existentes em rios, lagos, açudes, lagoas, baías ou águas jurisdicionais brasileiras. Parágrafo único. Incorre nas mesmas penas: I - quem causa degradação em viveiros, açudes ou estações de aqüicultura de domínio público; II - quem explora campos naturais de invertebrados aquáticos e algas, sem licença, permissão ou autorização da autoridade competente; III - quem fundeia embarcações ou lança detritos de qualquer natureza sobre bancos de moluscos ou corais, devidamente demarcados em carta náutica.

${ }^{330}$ Art. 34. Parágrafo único. Incorre nas mesmas penas quem: I - pesca espécies que devam ser preservadas ou espécimes com tamanhos inferiores aos permitidos; II - pesca quantidades superiores às permitidas, ou mediante a utilização de aparelhos, petrechos, técnicas e métodos não permitidos; III - transporta, comercializa, beneficia ou industrializa espécimes provenientes da coleta, apanha e pesca proibidas.

331 Art. 35. Pescar mediante a utilização de: I - explosivos ou substâncias que, em contato com a água, produzam efeito semelhante; II - substâncias tóxicas, ou outro meio proibido pela autoridade competente.

${ }^{332}$ Art. 38. Destruir ou danificar floresta considerada de preservação permanente, mesmo que em formação, ou utilizá-la com infringência das normas de proteção. Parágrafo único. Se o crime for culposo, a pena será reduzida à metade.

${ }^{333}$ Art. 38-A. Destruir ou danificar vegetação primária ou secundária, em estágio avançado ou médio de regeneração, do Bioma Mata Atlântica, ou utilizá-la com infringência das normas de proteção. Parágrafo único. Se o crime for culposo, a pena será reduzida à metade.

${ }^{334}$ Art. 40. Causar dano direto ou indireto às Unidades de Conservação e às áreas de que trata o art. 27 do Decreto $\mathrm{n}^{\circ}$ 99.274, de 6 de junho de 1990, independentemente de sua localização. $\S 3^{\circ}$ Se o crime for culposo, a pena será reduzida à metade.

${ }^{335}$ Art. 40-A. § 1ํㅡㄹ Entende-se por Unidades de Conservação de Uso Sustentável as Áreas de Proteção Ambiental, as Âreas de Relevante Interesse Ecológico, as Florestas Nacionais, as Reservas Extrativistas, as Reservas de Fauna, as Reservas de Desenvolvimento Sustentável e as Reservas Particulares do Patrimônio Natural. § $2^{\underline{0}}$ A ocorrência de dano afetando espécies ameaçadas de extinção no interior das Unidades de Conservação de Uso Sustentável será considerada circunstância agravante para a fixação da pena. $\S 3^{\circ}$ Se o crime for culposo, a pena será reduzida à metade.

${ }^{336}$ Art. 42. Fabricar, vender, transportar ou soltar balões que possam provocar incêndios nas florestas e demais formas de vegetação, em áreas urbanas ou qualquer tipo de assentamento humano.

${ }^{337}$ Art. 44. Extrair de florestas de domínio público ou consideradas de preservação permanente, sem prévia autorização, pedra, areia, cal ou qualquer espécie de minerais. 
$\S 2^{\mathrm{o}} ;^{339} 52 ;^{340} 53 ;^{341} 54, \S 3^{\mathrm{o}} ;^{342} 55$, parágrafo único $;^{343} 56, \S \S 1^{\mathrm{o}}, 2^{\mathrm{o}}$ e $3^{\mathrm{o}} ;^{344} 58 ;^{345} 62$, caput $\mathrm{e}$ parágrafo único $;{ }^{346} 65$, caput e parágrafo único $;{ }^{347} 66 ;{ }^{348} 67$, caput e parágrafo único; ${ }^{349} 68$, parágrafo único; ${ }^{350} 69$; e 69-A, caput e $\$ 1^{\mathrm{o}}{ }^{351}$ todos da Lei n. 9.605/98.

Como anteriormente exposto e já ressaltado pela doutrina (REALE JÚNIOR, 2005), o legislador inseriu na Lei de Crimes Ambientais determinadas condutas que não apresentam relevância penal. Embora haja tipificação, não chegam aos tribunais superiores casos referentes a ações ou omissões pouco lesivas ao meio ambiente (em geral arquivados em fase de inquérito policial ou extintos em primeira instância).

${ }^{338}$ Art. 49. Destruir, danificar, lesar ou maltratar, por qualquer modo ou meio, plantas de ornamentação de logradouros públicos ou em propriedade privada alheia. Parágrafo único. No crime culposo, a pena é de um a seis meses, ou multa.

339 Art. 50-A. Desmatar, explorar economicamente ou degradar floresta, plantada ou nativa, em terras de domínio público ou devolutas, sem autorização do órgão competente. $\S 2^{\underline{o}}$ Se a área explorada for superior a 1.000 ha (mil hectares), a pena será aumentada de 1 (um) ano por milhar de hectare.

${ }^{340}$ Art. 52. Penetrar em Unidades de Conservação conduzindo substâncias ou instrumentos próprios para caça ou para exploração de produtos ou subprodutos florestais, sem licença da autoridade competente.

${ }^{341}$ Art. 53. Nos crimes previstos nesta Seção, a pena é aumentada de um sexto a um terço se: I - do fato resulta a diminuição de águas naturais, a erosão do solo ou a modificação do regime climático; II - o crime é cometido: a) no período de queda das sementes; b) no período de formação de vegetações; c) contra espécies raras ou ameaçadas de extinção, ainda que a ameaça ocorra somente no local da infração; d) em época de seca ou inundação; e) durante a noite, em domingo ou feriado.

${ }^{342}$ Art. 54. $\S 3^{\circ}$ Incorre nas mesmas penas previstas no parágrafo anterior quem deixar de adotar, quando assim o exigir a autoridade competente, medidas de precaução em caso de risco de dano ambiental grave ou irreversível.

${ }^{343}$ Art. 55. Parágrafo único. Nas mesmas penas incorre quem deixa de recuperar a área pesquisada ou explorada, nos termos da autorização, permissão, licença, concessão ou determinação do órgão competente.

${ }^{344}$ Art. 56. $\S 1^{\mathrm{o}}$ Nas mesmas penas incorre quem: I - abandona os produtos ou substâncias referidos no caput ou os utiliza em desacordo com as normas ambientais ou de segurança; II - manipula, acondiciona, armazena, coleta, transporta, reutiliza, recicla ou dá destinação final a resíduos perigosos de forma diversa da estabelecida em lei ou regulamento. $\S 2^{\circ} \mathrm{Se}$ o produto ou a substância for nuclear ou radioativa, a pena é aumentada de um sexto a um terço. $\S 3^{\circ}$ Se o crime é culposo.

${ }^{345}$ Art. 58. Nos crimes dolosos previstos nesta Seção, as penas serão aumentadas: I - de um sexto a um terço, se resulta dano irreversível à flora ou ao meio ambiente em geral; II - de um terço até a metade, se resulta lesão corporal de natureza grave em outrem; III - até o dobro, se resultar a morte de outrem.

346 Art. 62. Destruir, inutilizar ou deteriorar: I - bem especialmente protegido por lei, ato administrativo ou decisão judicial; II - arquivo, registro, museu, biblioteca, pinacoteca, instalação científica ou similar protegido por lei, ato administrativo ou decisão judicial. Parágrafo único. Se o crime for culposo, a pena é de seis meses a um ano de detenção, sem prejuízo da multa.

${ }^{347}$ Art. 65 . Pichar, grafitar ou por outro meio conspurcar edificação ou monumento urbano. Parágrafo único. Se o ato for realizado em monumento ou coisa tombada em virtude do seu valor artístico, arqueológico ou histórico, a pena é de seis meses a um ano de detenção, e multa.

${ }^{348}$ Art. 66. Fazer o funcionário público afirmação falsa ou enganosa, omitir a verdade, sonegar informações ou dados técnico-científicos em procedimentos de autorização ou de licenciamento ambiental.

349 Art. 67. Conceder o funcionário público licença, autorização ou permissão em desacordo com as normas ambientais, para as atividades, obras ou serviços cuja realização depende de ato autorizativo do Poder Público. Parágrafo único. Se o crime é culposo, a pena é de três meses a um ano de detenção, sem prejuízo da multa.

${ }^{350}$ Art. 68. Parágrafo único. Se o crime é culposo, a pena é de três meses a um ano, sem prejuízo da multa.

351 Art. 69. Obstar ou dificultar a ação fiscalizadora do Poder Público no trato de questões ambientais. Art. 69-A. Elaborar ou apresentar, no licenciamento, concessão florestal ou qualquer outro procedimento administrativo, estudo, laudo ou relatório ambiental total ou parcialmente falso ou enganoso, inclusive por omissão. $\S 1^{\circ}$ Se o crime é culposo. $\S 2^{\circ}$ A pena é aumentada de $1 / 3$ (um terço) a $2 / 3$ (dois terços), se há dano significativo ao meio ambiente, em decorrência do uso da informação falsa, incompleta ou enganosa. 
Igualmente são poucos os processos que versam sobre crimes ambientais na modalidade culposa, embora o legislador tenha polvilhado a Lei de Crimes Ambientais com esses delitos. Foram encontrados apenas dois recursos com crimes culposos: um referente ao artigo 41, parágrafo único - de provocação de incêndio culposa em mata ou floresta; e outro relativo ao artigo 54 - de poluição culposa, ambos da Lei n. 9.605/98.

Quanto aos delitos que tiveram uma mínima incidência, destacam-se, por seção, os crimes contra a fauna: artigos 29 , caput e $\S 1^{\mathrm{o}}$, I; ${ }^{352} 32 ;^{353} 34 ;^{354}$ os crimes contra a flora: artigos $38 ; ;^{355} 39 ; ;^{356} 40 ; ;^{357} 41$, caput e parágrafo único; ${ }^{358} 45 ;{ }^{359} 46 ;^{360} 48 ; ;^{361} 50 ; ;^{362} 51 ; ;^{363}$ os crimes de poluição e outros crimes ambientais: 54, caput e $\S 1^{\circ}, \S 2^{\circ}$, I, II, III, IV e V; ${ }^{364}$ $55 ; ;^{365} 56 ; ;^{366} 60^{367}$ e $61 ;{ }^{368}$ os crimes contra o ordenamento urbano e o patrimônio cultural:

352 Art. 29. Matar, perseguir, caçar, apanhar, utilizar espécimes da fauna silvestre, nativos ou em rota migratória, sem a devida permissão, licença ou autorização da autoridade competente, ou em desacordo com a obtida:

$\S 1^{\circ}$ Incorre nas mesmas penas:

I - quem impede a procriação da fauna, sem licença, autorização ou em desacordo com a obtida;

353 Art. 32. Praticar ato de abuso, maus-tratos, ferir ou mutilar animais silvestres, domésticos ou domesticados, nativos ou exóticos.

${ }_{354}$ Art. 34. Pescar em período no qual a pesca seja proibida ou em lugares interditados por órgão competente.

355 Art. 38. Destruir ou danificar floresta considerada de preservação permanente, mesmo que em formação, ou utilizá-la com infringência das normas de proteção.

${ }^{356}$ Art. 39. Cortar árvores em floresta considerada de preservação permanente, sem permissão da autoridade competente.

357 Art. 40. Causar dano direto ou indireto às Unidades de Conservação e às áreas de que trata o art. 27 do Decreto $n^{\circ} 99.274$, de 6 de junho de 1990, independentemente de sua localização

358 Art. 41. Provocar incêndio em mata ou floresta. Parágrafo único. Se o crime é culposo, a pena é de detenção de seis meses a um ano, e multa.

${ }^{359}$ Art. 45. Cortar ou transformar em carvão madeira de lei, assim classificada por ato do Poder Público, para fins industriais, energéticos ou para qualquer outra exploração, econômica ou não, em desacordo com as determinações legais.

${ }^{360}$ Art. 46. Receber ou adquirir, para fins comerciais ou industriais, madeira, lenha, carvão e outros produtos de origem vegetal, sem exigir a exibição de licença do vendedor, outorgada pela autoridade competente, e sem munir-se da via que deverá acompanhar o produto até final beneficiamento:

Parágrafo único. Incorre nas mesmas penas quem vende, expõe à venda, tem em depósito, transporta ou guarda madeira, lenha, carvão e outros produtos de origem vegetal, sem licença válida para todo o tempo da viagem ou do armazenamento, outorgada pela autoridade competente.

361 Art. 48. Impedir ou dificultar a regeneração natural de florestas e demais formas de vegetação.

362 Art. 50. Destruir ou danificar florestas nativas ou plantadas ou vegetação fixadora de dunas, protetora de mangues, objeto de especial preservação.

363 Art. 51. Comercializar motosserra ou utilizá-la em florestas e nas demais formas de vegetação, sem licença ou registro da autoridade competente.

${ }^{364}$ Art. 54. Causar poluição de qualquer natureza em níveis tais que resultem ou possam resultar em danos à saúde humana, ou que provoquem a mortandade de animais ou a destruição significativa da flora. $\S 1^{\circ} \mathrm{Se} o$ crime é culposo. $\S 2^{\circ}$ Se o crime: I - tornar uma área, urbana ou rural, imprópria para a ocupação humana; II causar poluição atmosférica que provoque a retirada, ainda que momentânea, dos habitantes das áreas afetadas, ou que cause danos diretos à saúde da população; III - causar poluição hídrica que torne necessária a interrupção do abastecimento público de água de uma comunidade; IV - dificultar ou impedir o uso público das praias; V - ocorrer por lançamento de resíduos sólidos, líquidos ou gasosos, ou detritos, óleos ou substâncias oleosas, em desacordo com as exigências estabelecidas em leis ou regulamentos.

365 Art. 55. Executar pesquisa, lavra ou extração de recursos minerais sem a competente autorização, permissão, concessão ou licença, ou em desacordo com a obtida. 
artigos $63^{369}$ e $64 ;^{370}$ e finalmente os crimes contra a administração ambiental: apenas o artigo $68 ;{ }^{371}$ todos da Lei n. 9.605/98.

Os delitos que apresentaram maior incidência processual foram os previstos nos artigos 38 (destruição ou danificação de floresta de preservação permanente); 46 (recebimento e aquisição de produtos vegetais sem licença); $54, \S 2^{\circ}$ (crime de poluição); e 55 (execução de pesquisa ou extração de recursos minerais sem autorização). Na maioria dos casos, debatia-se a competência estadual ou federal para o processamento do feito, pelo fato de a fiscalização ser realizada por órgão federal (IBAMA) ou por tratar-se, em diversos momentos, de área de preservação permanente em propriedade privada.

Apesar da incidência mais elevada que a de outros tipos penais, abaixo apenas dos artigos 38 e 46, o crime de poluição do artigo 54 (com 12 acórdãos) reforçou a hipótese de que o delito não é, ao final, sancionado, desembocando em uma sensação de impunidade a rondar os casos de poluição ambiental. Além da dificuldade de adequação fática aos vagos termos "em níveis tais", inviabilizando o preenchimento dos requisitos necessários para a denúncia (artigo 41 do Código de Processo Penal), outro problema apresentado foi de adequação processual da pessoa jurídica no pólo passivo da ação, diante da falta de especificação legal.

Note-se que, diante dos dados obtidos na esfera judicial dos tribunais superiores, a Lei de Crimes Ambientais apresenta inefetividade instrumental da norma, no sentido de carência de aplicação efetiva das sanções penais previstas na legislação brasileira. ${ }^{372}$ Dos

\footnotetext{
${ }^{366}$ Art. 56. Produzir, processar, embalar, importar, exportar, comercializar, fornecer, transportar, armazenar, guardar, ter em depósito ou usar produto ou substância tóxica, perigosa ou nociva à saúde humana ou ao meio ambiente, em desacordo com as exigências estabelecidas em leis ou nos seus regulamentos.

${ }^{367}$ Art. 60. Construir, reformar, ampliar, instalar ou fazer funcionar, em qualquer parte do território nacional, estabelecimentos, obras ou serviços potencialmente poluidores, sem licença ou autorização dos órgãos ambientais competentes, ou contrariando as normas legais e regulamentares pertinentes.

${ }^{368}$ Art. 61. Disseminar doença ou praga ou espécies que possam causar dano à agricultura, à pecuária, à fauna, à flora ou aos ecossistemas.

369 Art. 63. Alterar o aspecto ou estrutura de edificação ou local especialmente protegido por lei, ato administrativo ou decisão judicial, em razão de seu valor paisagístico, ecológico, turístico, artístico, histórico, cultural, religioso, arqueológico, etnográfico ou monumental, sem autorização da autoridade competente ou em desacordo com a concedida.

${ }^{370}$ Art. 64. Promover construção em solo não edificável, ou no seu entorno, assim considerado em razão de seu valor paisagístico, ecológico, artístico, turístico, histórico, cultural, religioso, arqueológico, etnográfico ou monumental, sem autorização da autoridade competente ou em desacordo com a concedida.

${ }^{371}$ Art. 68. Deixar, aquele que tiver o dever legal ou contratual de fazê-lo, de cumprir obrigação de relevante interesse ambiental.

${ }^{372}$ Em análise do Direito Penal ambiental português, INÊS HORTA PINTO constata que, em 10 anos de vigência da norma portuguesa, a porcentagem de arquivamento foi significativa, alcançando $95 \%$ dos casos, sem nenhuma condenação por crime de poluição e nenhum processo por danos contra a natureza (2006, p. 1117). PINTO indica que essa realidade não é específica de Portugal, visto que a Espanha demorou cinco anos para ter sua primeira sentença condenatória por crime ambiental, e que a Alemanha aplica sua legislação apenas a
} 
150 acórdãos $^{373}$ analisados, apenas $12^{374}(8 \%)$ indicaram decisão condenatória com aplicação de sanção penal. ${ }^{375}$ Neste universo de 12 acórdãos, quatro ainda não apresentavam trânsito em julgado e um estava prescrito in concreto, restando tão-somente sete condenações definitivas. Mesmo considerando o total de julgados, sem exclusão dos passíveis de recurso e do prescrito, aponta-se que somente 12 artigos $(21,8 \%)$ de 55 crimes previstos da Lei de Crimes Ambientais alcançaram uma sentença condenatória no STJ e STF. Este baixo índice de crimes aplicados, por si só, pode ser considerado um sinal de fracasso da lei. ${ }^{376}$

Nos casos de condenação definitiva, a maior parte, não ultrapassando a pena de 2 anos, foi substituída por penas restritivas de direitos (seis casos em sete), e em apenas um caso manteve-se a condenação em privativa de liberdade e regime fechado, apesar de o quantum da pena admitir a substituição.

À semelhança da constatação trazida por ANA CAROLINA ALFINITO VIEIRA ${ }^{377}$ na pesquisa sobre os crimes financeiros realizada pela Fundação Getúlio Vargas, verifica-se,

fatos bagatelares, a pequenos poluidores de baixo nível social (2006, p. 1117). Conclui a autora que "o Direito Penal do Ambiente só realizará a sua função de tutela do bem jurídico e de prevenção geral e especial se houver um efectivo sancionamento das condutas gravemente ofensivas daquele bem, com o conseqüente conhecimento por parte da comunidade dessa aplicação.” (2006, p. 1116).

${ }^{373}$ Referentes a 58 acórdãos sobre a Lei $9.605 / 98$ no STF, acrescidos de 92 Recursos Especiais sobre crimes ambientais no STJ.

${ }_{374}^{374}$ Somatória de 4 acórdãos de habeas corpus do STF e 8 acórdãos de Recurso Especial do STJ.

375 Reitera-se que o trabalho restringiu-se ao âmbito de aplicação da norma na decisão judicial e não acompanhou a efetiva execução da pena aplicada.

${ }^{376}$ No mesmo sentido, EDUARDO REALE FERRARI expressa, em análise aos dados obtidos na pesquisa sobre "A aplicação da lei de crimes contra o sistema financeiro pelos tribunais brasileiros", que: "Para vocês terem uma noção, $80 \%$ dos tipos penais da Lei 7492/86 se restringem a seis infrações, nós temos 23 crimes e desses 23 crimes $80 \%$ pela pesquisa se restringe a 6 infrações penais, isso é assustador. Nenhuma decisão que tenha voltado ou que tenha reformado absolvendo algo que fora condenado, nenhuma delas, é algo impressionante! Isso apenas faz, primeiro, ficar claro que a lei penal quando trabalha já é sinal de um fracasso. Professor Reale Jr. diz isso. A lei penal já é a prova do fracasso, Direito penal já é a comprovação de que todos os meios de prevenção falharam, e, portanto, é preciso investir cada vez mais nos aspectos de prevenção, cada vez mais nos aspectos, para que a infração não seja praticada, através de informações, através de inteligência, através de troca de idéias, de interação entre os órgãos e temos que parar com o negócio de que Ministério Público é inimigo, advogado é inimigo, até pela composição da mesa de manhã o juiz e promotor estavam aqui, advogado ali, quer dizer, tem que ter a maior proximidade, porque nós todos buscamos a mesma coisa, que é a eficácia; todos aqui queremos a eficácia, a realizabilidade, que a norma seja eficaz, que a norma seja realizável" (2010, p. 61).

${ }^{377}$ Nas palavras da autora: “A partir dos dados analisados, pode-se constatar que a substituição de penas privativas de liberdade por penas restritivas de direitos é uma prática comum nos casos de condenação pelos crimes contidos na Lei 7.492. Em $1^{a}$ instância, a substituição foi efetuada em $60,3 \%$ dos casos nos quais a pena aplicada permitia a aplicação de penas restritivas de direitos no lugar das privativas de liberdade, e nos Tribunais Regionais Federais o mesmo índice sobe para 71\%. No entanto, não existe por parte do judiciário um esforço no sentido de justificar ou individualizar a pena restritiva de direitos aplicada em cada caso. As penas alternativas mais aplicadas pelos juízes são as de prestação de serviços à comunidade e prestação pecuniária, mas em nenhum momento houve uma reflexão acerca da adequação destas penas ao caso concreto. Ademais, duas modalidades de penas que poderiam ser bastante adequadas aos crimes financeiros a perda de bens ou valores e a interdição temporária de direitos - não foram aplicadas e nem sequer cogitadas 
nos crimes ambientais, uma propensão do judiciário à substituição das penas privativas de liberdade quando do cumprimento do requisito objetivo de 4 anos de condenação em restritiva de direitos, apesar de não existir um esforço na individualização das medidas alternativas aplicadas, restringindo-se, em geral, à prestação de serviços à comunidade e à prestação pecuniária. ${ }^{378}$

A pequena quantidade de decisões condenatórias no âmbito dos tribunais superiores sinaliza que, em quase 13 anos de vigência da Lei de Crimes Ambientais, há pouca aplicação desta peça da legislação penal no STJ e STF, representando uma espécie de descriminalização branca. ${ }^{379}$ Somada a essa informação, o fato de os processos originários do Supremo Tribunal Federal (inquéritos policiais e ação penal) se encerrarem sem condenação $^{380}$ - por inépcia da denúncia, insignificância do ato e transação penal confirma o enfraquecimento da aplicação de pena por via do processo penal, com ampla defesa e contraditório, em face da aplicação dos institutos da Lei n. 9.099/95.

nas decisões analisadas, o que demonstra uma falta de reflexão crítica sobre as possíveis funções e benefícios que a pena alternativa pode trazer para este tipo de crime" (VIEIRA, 2010, p. 91).

${ }^{378}$ Em apenas um caso, como narrado anteriormente, houve imposição de restritivas de direitos consistentes em restauração do local dos fatos, abandono da área embargada e demolição da construção realizada.

379 Ao tratar da finalidade da pena, REALE JÚNIOR afirma que "a não-aplicação da lei, como a não-imposição de uma pena, nos casos de descriminalização branca, reflete que o valor tutelado não mais tem significado social relevante, sendo desnecessário e incongruente reafirmar este valor pela aplicação da lei [...] não há valor a ser afirmado, não se justifica a pena, e opera-se a descriminalização, mesmo que vigente a norma incriminadora" (2009, p. 56).

${ }^{380}$ DIAS, partidário de um endurecimento do Direito Penal econômico, afirma que "em todos os Estados se pressente um sentimento generalizado de injustiça estrutural, relativamente ao qual a impunidade dos delinquentes económicos ou a sua injustificada punição menor adquire acentuada ressonância simbólica; o que - diga-se de passagem - é particularmente visível nos Estados democráticos, atento o papel aí desempenhado pelos meios de (livre) comunicação social. É para inverter este estado de coisas e para obviar à generalização de atitudes de cinismo e evasão que a sociedade deve formular particulares exigências ao seu ordenamento penal económico. Com o que, afinal, em nada se contraria, mas antes substancialmente se realiza um princípio de igualdade material entre os cidadãos” (2006, p. 71). 


\section{Conclusões}

Com o objetivo de justificar - por meio das teorias das penas - as sanções penais previstas para os crimes contra o meio ambiente, este trabalho pretendeu fazer uma análise crítica dos fundamentos retributivo, preventivo e simbólico das penas, para em seguida relacionar os argumentos abordados com as características próprias do âmbito ecológico.

Seguindo esse propósito, adotou-se a premissa de que a legitimidade do Estado para impor a pena, que ultrapassa a mera imposição utilitária de um mal voltado a promover o bem social, depende, primordialmente, de justificativas plausíveis e racionais. Apenas ancorado em justificativas passíveis de debate democrático pode o Estado aplicar a sanção penal, esquivando-se da acusação de que a intervenção jurídico-penal seria totalitária ou arbitrária. Por esse motivo, o debate sobre as teorias da pena resulta fundamental para se verificar o uso legítimo da sanção penal em um Estado democrático de Direito, que valoriza os direitos fundamentais e os interesses sociais.

Ademais da argumentação formal que autoriza legalmente o poder público para atuar coercitivamente em resposta aos atos considerados crimes, a doutrina traduz os motivos e limitações dessa atuação estatal gravosa, para garantir a paz social e os bens jurídicos, por via das teorias das penas, afastando o desejo privado de auto-proteção (a vingança privada).

Ainda que tal debate seja relativamente infenso a contribuições empíricas, e que tenha havido neste trabalho um esforço inicial de análise de julgados dos tribunais superiores brasileiros, mostra-se imprescindível ampliar as indagações de campo sobre se as modificações sociais no mundo globalizado, com a expansão legislativa penal, seguem trazendo razões para considerar a violência legal aceitável ou justificável. Elegeu-se o âmbito do Direito Penal ambiental, fruto imediato dessa modernização no ordenamento, como instrumento para revolver esta questão, quer no plano teórico, quer no exame de decisões judiciais potencialmente aptas a problematizar os fundamentos das penas.

Em um primeiro momento, a partir do estudo das teorias das penas, concluiu-se que as doutrinas tradicionais recebem críticas que focalizam inclusive as premissas fundamentais de cada teoria da pena, o que dificulta sobremaneira o debate acerca dos fins 
legitimados da pena, e praticamente impede o alcance consensual de uma posição coerente, isenta de contradições, sobre a finalidade moderna das sanções criminais. É certo, sem embargo, que este trabalho considerou menos relevante se posicionar sobre a finalidade da pena "mais acertada", priorizando a indicação cristalina de que os diversos posicionamentos desenvolvidos sobre o tema apresentam contradições insuperáveis. Reitere-se: a resolução deste impasse teórico, que escapa aos propósitos da presente dissertação, sequer se anuncia no horizonte doutrinário.

Após o capítulo de introdução do tema, descreveram-se no segundo capítulo as superadas concepções retributivas clássicas - que, além de considerar o homem em um plano idealizado de liberdade plena (inexistente), ignoram a utilidade social da pena, cuja aplicação resultava obrigatória em qualquer ocasião, por seu valor axiológico, independente da proteção dos bens jurídicos relevantes. Anotou-se que o posicionamento retributivista não apresenta limites ao poder punitivo estatal, podendo desembocar em sistemas totalitários, distanciados de racionalismo e de valores humanitários.

Ainda que a teoria absoluta tenha trazido relevantes argumentos - por exemplo, a utilização da pena como reação frente a algo já sucedido (Direito Penal do fato), ou a proporcionalidade do castigo na medida da culpabilidade do sujeito infrator - não se pode concluir que seja suficiente como uma justificativa exclusiva da pena. Em continuidade do raciocínio sobre reação e proporcionalidade, já se expressou a dificuldade de alcançar a perfeita e satisfatória igualdade entre o dano causado e a reparação à vítima e à sociedade, mesmo com a utilização da proporção normativa hegeliana.

Se por um lado o fim retributivo não logrou êxito, por outro era de se esperar o sucesso das teorias preventivas. Todavia, igualmente se tem expressado que as concepções utilitárias sofrem críticas severas, que compreendem as suas variadas vertentes. Com efeito, a prevenção geral negativa de coação psicológica, baseada justamente na punição exemplar, apresenta questionável instrumentalização do homem, na medida em que o condenado representa tão-somente um objeto de demonstração de punição aos outros cidadãos, à míngua da dignidade humana. Sobre a prevenção geral, as objeções transbordam ao se analisar a variante fundamentadora, representada pelos pensamentos de JAKOBS. Nesse sentido, o reconhecimento e a manutenção da vigência da norma sob uma orientação essencialmente comunicativa não parece legitimar o conteúdo aflitivo da pena, eis que origina um pensamento circular, no qual o objeto protegido deixa de ser os bens jurídicos para ser o próprio ordenamento. 
Em contrapartida, a prevenção geral de variante limitadora - mais admitida pela doutrina - estabelece parâmetros de limitação ao poder punitivo excessivo, ao mesmo tempo em que visa a reforçar a confiança no ordenamento para lograr o efeito de pacificação social. De todo modo, nenhuma das teorias preventivo-gerais escapa da constatação de que se fundamentam em uma suposição utópica de que todas as pessoas seja na condição de infratores ou de cidadãos que confiam no Direito - têm pleno conhecimento da norma (situação pouco provável, a não ser para profissionais especializados na matéria). Tais teorias partem, pois, da hipótese de que os cidadãos são plenamente capazes de utilizar seu raciocínio, seu poder de cálculo, para ser dissuadidos da ação criminosa em razão dos comandos emitidos pela norma.

Além disso, pondera-se que a premissa das teorias relativas pode criar uma falsa expectativa a respeito da força da cominação legal. Em primeiro lugar, frente à ausência de limites determinados, a fé no ordenamento costuma levar à crença de que quanto mais elevadas as penas, menor será o interesse na delinquência e, portanto, viabiliza o terrorismo penal legislativo. Em segundo lugar, a criminologia indica que não importa tanto a magnitude da ameaça penal, pois outros fatores externos são mais valiosos para a prática ou a desistência da prática do injusto. Ilustram-se tais ponderações, respectivamente, com a internalização de valores que levam o sujeito ao crime ou com o medo de ser surpreendido por uma fiscalização e perseguição intensificada.

A prevenção especial tampouco escapa ilesa de críticas. Ao tratar o infrator como doente, o sistema penal, nessa teoria, confere poderes autoritários de pedagogo ao Estado, que adquire a capacidade de manipular a vontade dos cidadãos, modelando suas personalidades. A sanção penal, por estar vinculada ao perfil do infrator, mostra-se incompatível com o Direito Penal do fato, ademais de não prever uma duração determinada do castigo estatal.

Mais ainda, a busca pela não reincidência não tem sentido quando, desde o princípio, o infrator não necessitava de ressocialização (nos casos de fatos culposos ou injustos irrepetíveis). $\mathrm{Na}$ prática, mostra-se notória a incongruência do pensamento da ressocialização com a consideração do sistema carcerário de privação de liberdade, onde o distanciamento dos valores sociais é mais significativo.

Diante dessas fissuras nas teorias das penas, pode-se concluir que a indicação de justificativas plausíveis para a intervenção jurídico-penal do Estado encontra-se 
extremamente dificultada. Pior: neste trabalho, procurou-se demonstrar que os defeitos dessas teorias se agravam quando analisados no âmbito do Direito Penal do meio ambiente.

Iniciando o estudo pelo bem jurídico ambiental, convém ressaltar que se trata da proteção de um bem refletido em setores difusos da população, cuja marca central é a indeterminação das vítimas nos casos de sua lesão ou colocação em perigo. Por não ser um interesse jurídico individual, como aqueles com que o Direito Penal estava habituado a trabalhar, as estruturas de proteção e imputação objetiva ecológicas desafiam o parâmetros da prevenção geral integrativa limitadora.

Em outras palavras, a prevenção positiva limitadora não consegue fixar suas bases com relação a diversos tipos penais ambientais, pois o bem jurídico difuso se apresenta pouco claro, de difícil determinação. Esta natureza opaca é importante porque, diante da dificuldade de delimitar as unidades lesionáveis no âmbito meio ambiental, não se pode destacar, na interpretação dos tipos penais, qual é o interesse protegido pelo Estado, para que dito interesse seja respeitado pelos demais. Ou seja, é frágil a formação do centro de valores internos da sociedade, quando se está diante de um bem jurídico vago como o meio ambiente, inclusive porque os ataques a ditos interesses não são facilmente sentidos pela comunidade (a depender da análise técnico quantitativa).

Seguindo com a perspectiva da sociedade, aduz-se que a intervenção do Direito Penal pretendeu-se mais democrática, para não apenas recair sobre os cidadãos menos abastados, mas também sobre os detentores dos meios de produção. É discutível, contudo, se esta atuação estatal resulta legítima sob a concepção da prevenção especial positiva. Sobrevém aparente incongruência da busca pela ressocialização justamente dos sujeitos mais adaptados à lógica social, ou seja, mais entrelaçados às atividades produtivas socialmente valorizadas. Se o pensamento social estimula ao máximo a produção, em certa medida estimula igualmente as condutas supostamente atentatórias à natureza. Decorre desta contradição uma ironia perigosa para a legitimidade estatal: a mudança dos valores não se configuraria necessária para aqueles que atuam de maneira neutra ou estão submetidos a condição que não podem controlar ou dominar, debilitando, portanto, a prevenção especial positiva.

Segundo essa interpretação, não caberia ressocialização à incriminação do delito culposo. Ressalte-se, porém, que a reforma legislativa - ampliativa dos delitos contra o meio ambiente - estendeu as hipóteses de comissão culposa dos delitos ecológicos com a redação dos parágrafos únicos dos artigos $38,41,49,62,67,68$; parágrafos $3^{\circ}$ dos artigos 
40, 40-A, 56; e parágrafos $1^{\circ}$ dos artigos 54 e 69-A, todos da Lei n. 9.605/98, ampliando, por consequência, a carência da prevenção especial positiva a tais fatos.

Após a análise do bem jurídico do meio ambiente e dos sujeitos destinatários das normas penais de proteção ecológica, destacou-se - como aqui reiteramos - os problemas derivados da estrutura do injusto penal. Uma primeira questão, crucial, consiste na marca característica da legislação penal ambiental de utilização da acessoriedade administrativa, ou seja, de remissão dos tipos incriminadores a conceitos, normas ou atos administrativos complementares. Isso acarreta dificuldades de conhecimento da norma proibitiva (seja, por exemplo, pela disparidade de preceitos nos regramentos e portarias dos diferentes Estados e municípios, pela arbitrariedade administrativa na concessão de autorizações, pela velocidade com que tais normativos são alterados, ou pela ausência de fixação de claros limites de riscos permitidos), dificultando a fidelidade do cidadão ao ordenamento. Consequentemente, torna-se inviável a pretensão comunicativa da prevenção geral integrativa fundamentadora. Dito de outro modo, se o ordenamento jurídico é vago, incompreensível e carente de sistematização, não é suficientemente harmônica a comunicação do sujeito com a norma para que haja o fortalecimento da confiança geral na validade e na vigência do sistema normativo.

Tão relevante como a problemática anterior é a questão dos delitos de perigo abstrato. Esse tipo de delito provoca distensões candentes a propósito da função retributiva, uma vez que delitos de perigo abstrato erodem a proporcionalidade da pena com o fato imputado e, ainda, lançam dúvidas sobre a determinação dos fatos passados passíveis de sanção penal. No âmbito do meio ambiente, com a utilização dos delitos de perigo abstrato, antecipam-se as barreiras de proteção para que o injusto se configure antes da produção do resultado lesivo, ou antes que haja colocação do bem jurídico em perigo concreto. $\mathrm{O}$ equilíbrio da proporcionalidade e a medida de culpabilidade para a pena, frente à ausência de danos computáveis, tornam-se praticamente inaplicáveis. Assim, gera-se uma desconexão entre o quantum retributivo da pena e a conduta de perigo abstrato, ainda mais nos casos de acumulação ou sinergia.

Para finalizar a análise das teorias das penas, cumpre tecer breves observações sobre a prevenção geral negativa e a prevenção especial negativa. Em primeiro lugar, sustentou-se que a função intimidatória perdeu força nos últimos anos como medida profilática. $\mathrm{Na}$ estrutura dos crimes contra o meio ambiente, cabe destacar a mudança de paradigma do Direito Penal humanitário, que reduziu a imposição de penas privativas de 
liberdade, principalmente nos casos de reparação do dano ecológico. A lógica preventiva negativa (geral ou especial) aparentou ser abrandada, com o abandono de sanções penais elevadas e cruéis como contra-estímulo à prática da conduta delituosa, evitando-se a segregação do infrator ambiental por meio de reclusão na prisão. De fato, a reparação do dano indica um desejo do legislador de afastar-se do aspecto dissuasório dos fatos futuros, privilegiando a solução do conflito presente para restabelecer o estado de paz social.

De qualquer forma, a intimidação não está absolutamente excluída pela diminuição dos casos de prisão. Pelo contrário, atualmente a carga repressiva é representada pelo gravame do processo penal. Em outras palavras, entende-se que o indivíduo responder a um processo judicial na esfera penal e a posterior aplicação de pena de prestação de serviço à comunidade é um ônus severo, visto que o indivíduo absorve intimidação das instituições públicas envolvidas na persecução criminal - ainda que tal intimidação não consista em privação de liberdade. O Direito Penal fragiliza-se com o abuso dos mecanismos de transação penal e suspensão condicional do processo, que interrompem o procedimento penal com imposição de medidas coercitivas, pois a intimidação estatal transporta-se da pena para o processo, no qual se admitem formas de coerção que precedem - e pior, prescindem de - qualquer análise de imputação.

Do exposto, concluímos que, em especial no Direito Penal ambiental, comprova-se um desamparo às teorias das penas (fim retributivo e preventivo) se isoladamente consideradas. Tais teorias aparentam servir tão-somente como recurso retórico para dissimular o discurso extra-oficial simbólico das penas.

Apesar da conclusão anterior, devemos chamar a atenção a importantes considerações sobre o fim simbólico da pena no Direito Penal ambiental. Posicionamo-nos no sentido de que o fim simbólico não serve como fundamento legitimador exclusivo da sanção penal, no sentido da falsa instrumentalidade e efetividade. Contudo, isso não significa que, diante do delito ecológico, o legislador não possa buscar o simbolismo como meio adicional e complementar aos efeitos instrumentais para a construção de uma ética de preservação ambiental. É forçoso atentar para os riscos envolvidos no recurso ao simbolismo: a absolutização dos aspectos simbólicos, embora capaz de gerar uma consciência social sobre o alvo dos tipos penais em questão, pode no médio prazo desembocar em uma perda de confiança no ordenamento, por sua inefetividade na resolução real dos conflitos. Em outros termos, é inegável que a condenação penal traz uma maior reprovação ético-social em termos simbólicos. O que se repudia não é o efeito 
auxiliar à prevenção introduzido pelos aspectos expressivos-integradores do simbolismo, mas a perda de confiança ao longo do tempo se o órgão estatal não executa as sanções previstas por carência dos efeitos instrumentais, restando a imputação penal resumida à mera comunicação de cumprimento impossível (e sem fins utilitários, ou seja, sem proteção de bens jurídicos penalmente relevantes). Esta perda de confiança, porém, pode ser o resultado inexorável dos julgados relacionados à Lei de Crimes Ambientais, em que é regra a inexecução das sanções previstas em lei, como apontou o levantamento empírico presente neste trabalho.

Diante dessas ameaças, adotamos a premissa de que a intensa carga de censura social, própria do efeito simbólico, deve ser utilizada com cautela, inserida em um contexto bem edificado de tipos penais, com estruturas de imputação compatíveis com a política criminal, a valorizar os princípios fundamentais do Direito Penal. No caso dos crimes ambientais no Brasil, o prognóstico singelo que este trabalho proporia é uma reforma substancial, focalizada na eliminação da maior parte dos tipos hoje existentes e na distribuição mais equilibrada de sanções entre as esferas criminal e administrativa (para a concretização do princípio do ne bis in idem).

Não obstante tais criticas ao simbolismo, principalmente sob as lentes do Direito Penal ambiental, cumpre constatar que ele se encontra sobreposto aos demais fins da pena - que devem ser verificados de forma unificada e não isolada. Ao se privilegiar o caráter formativo e informativo da consciência ecológica (viés positivo do Direito Penal simbólico), arrisca-se deixar de atender à efetiva proteção do meio ambiente. Nestas situações, o Direito Penal logra êxito em seu intento de apresentar à sociedade uma convicção de grave reprovabilidade à destruição ambiental, mas não encontra justificativas plausíveis para sua legitimação, tampouco instrumentos efetivos de proteção.

Argumenta-se neste trabalho que, ainda que se possam impingir finalidades flutuantes às penas, com características próprias no âmbito do Direito Penal econômico, não se pode abdicar de uma estrutura mínima de prevenção geral positiva (e unificação dos elementos retributivos e simbólicos) no contexto de um Estado democrático de Direito.

Nesse sentido, parece-nos que o ideal seria uma reforma quantitativa e qualitativa do injusto ambiental, limitando o âmbito de atuação jurídico-penal - de forma subsidiária aos casos mais gravosos ao bem jurídico, por meio de estruturas jurídico-dogmáticas compatíveis com os princípios da intervenção mínima e do garantismo penal, e asseguradoras dos fins instrumentais, conjugados com os fins simbólicos da pena (em sua 
faceta negativa), dentro de uma perspectiva de teoria mista da pena. Enquanto a mencionada reforma não ocorre, nada impede a interpretação restritiva dos tipos existentes - sob os limites da intervenção mínima do Direito Penal - com o fito de limitar a intervenção penal aos casos extremos e mais gravosos ao bem jurídico.

A idêntica proteção do bem jurídico ambiental nas esferas penal e administrativa representada pelo quadro comparativo da Lei de Crimes Ambientais e as infrações administrativas existentes no ordenamento brasileiro - sinaliza a falta de critério de subsidiariedade e fragmentalidade da tutela penal. Afastando os tipos de mera conduta administrativa e as descrições abertas, a esfera penal ficaria limitada a poucos tipos penais, associados principalmente a casos de poluição e grandes desmatamentos, o que não ocorre nos dias atuais.

A análise da jurisprudência dos tribunais superiores brasileiros facilita a percepção desse descompasso. Observou-se neste trabalho que tem sido tímida a aplicação de penas ambientais pelo Supremo Tribunal Federal e pelo Superior Tribunal de Justiça. Em quase 13 anos de vigência da Lei de Crimes Ambientais, apurou-se que não houve nenhuma decisão condenatória sobre questão ambiental nos Recursos Extraordinários do STF e apenas quatro acórdãos em sede de Habeas Corpus tratando de condenação. No STJ, o levantamento foi igualmente pouco expressivo, com oito acórdãos que enfrentaram a questão da condenação em crimes ambientais.

Em regra, os julgados que tratam da Lei n. 9.605/98 versam sobre questões processuais de inépcia da denúncia e sobre competência processual. O volume de acórdãos sobre essas matérias, de certa forma, sinaliza que há uma significativa utilização do processo penal como forma de intimidação, mesmo que não se verifique a posteriori uma condenação efetiva.

No Supremo Tribunal Federal, a inaplicação da Lei n. 9.605/98 em decisões finais meritórias (Recursos Extraordinários) pode derivar de causas variadas. Neste trabalho levantou-se a hipótese de vedação de reexame de provas em sede de Recurso Extraordinário; o curto período de vigência da Lei n. 9.605/98, que não teria permitido o esgotamento das medidas recorríveis anteriores; e, principalmente, a solução dos conflitos por meio da transação penal ou da suspensão condicional do processo, que desmotiva o acusado a desencadear a revisão dos acordos. 
Em análise detalhada dos acórdãos condenatórios (HCs do STF e Recursos Especiais do STJ), pode-se afirmar que são escassos os casos de condenação transitada em julgado com pena de privativa de liberdade sem conversão para penas restritivas de direitos. Em regra, as condenações são verificadas em casos de pouca expressão lesiva, em que não se justificam sanções diferentes das administrativas.

Nenhum julgado tratou expressamente das finalidades das penas ou da adequação da sanção penal ao caso concreto, indicando o interesse do Estado na reafirmação do valor meio ambiental, por meio do mecanismo penal, ainda que isso implique sanções similares ou equiparadas às administrativas. Essa constatação deriva, principalmente, do processo referente ao Habeas Corpus n. 84.821-4/MG, do Supremo Tribunal Federal, em que o juiz de primeira instância, ainda que contra os requisitos do artigo 44 do Código Penal, substituiu a pena privativa de liberdade em sanções pecuniárias e de multa, diante do excessivo rigor da sanção penal frente à conduta praticada.

São carregados os matizes desta reflexão sobre os julgados em matéria criminal ambiental. Ao contrário da expectativa gerada com a edição da Lei de Crimes Ambientais, não se constatou a temática de destruição ambiental (referente à poluição e desmatamento) por pessoa jurídica, que, em tese, teria maior potencial lesivo. No âmbito do Superior Tribunal de Justiça, as conclusões são similares, em que pese existir uma sentença condenatória contra pessoa jurídica neste tribunal. Somados os acórdãos do STF e STJ, apenas um manteve a pena de prisão em regime fechado para o cumprimento da condenação ambiental (em caso de extração indevida de madeira).

Conclui-se que, tanto no âmbito teórico, quanto no âmbito empírico, a tutela penal ambiental encontra um déficit de efetividade, traduzido ou confirmado por uma legislação penal primordialmente simbólica. Percebe-se com perplexidade que a tutela penal ambiental - e quiçá a tutela penal como um todo - assume ares contraprodutivos, distanciando-se da solução dos problemas sociais mais graves. A ilusão da proteção penal parece camuflar a necessidade de fortalecimento de outras vias, não-penais, para a solução de males como a degradação ambiental. No mesmo passo, encontra-se o Direito Penal em momento decisivo, carente de ajustes profundos, para lidar com bens jurídicos que albergam novas realidades, mas também para reafirmar sua legitimidade de forma ampla e inequívoca. Oxalá esta pedra no meio do caminho motive a reflexão acadêmica, a atuação das instituições criminais e a transformação legislativa necessárias para reverter o quadro atual. 


\section{Referências}

ABEL SOUTO, Miguel. Teorías de la pena y límites al ius puniendi desde el Estado Democrático. Madrid: Editorial Dilex, 2006.

ALENZA GARCÍA, José Francisco. Las sanciones administrativas y penales en materia ambiental: funciones y problemas de articulación. In: CORCOY BIDASOLO, Mirentxu (dir.). Derecho Penal de la empresa. Navarra: Universidad Pública de Navarra, 2002. p. 595-612.

ANITUA, Gabriel Ignacio. Histórias dos pensamentos criminológicos. Tradução: Sérgio Lamarão. Rio de Janeiro: Revan, 2008.

ANTUNES, Paulo de Bessa. Federalismo e Competências Ambientais no Brasil. Rio de Janeiro: Lumen Juris, 2007.

ATIENZA, Manuel. Contribución a una teoría de la legislación. Madrid: Civitas, 1997.

BARATTA, Alessandro. Funções instrumentais e simbólicas do direito penal: Lineamento de uma teoria do bem jurídico. Revista Brasileira de Ciências Criminais, São Paulo, v.2, n. 5, p. 5-24, jan./mar. 1994.

BARBOSA MOREIRA, José Carlos. A proteção jurisdicional dos interesses coletivos e difusos. In: GRINOVER, Ada Pellegrini (coord.) A tutela dos Interesses Difusos. São Paulo: Max Limonad, 1999. p. 98-106.

BARREIRO, Agustín Jorge. El bien jurídico protegido en los delitos contra el medio ambiente en el CP de 1995. In: BARREIRO, Agustín Jorge; CANCIO MELIÁ, Manuel. Estudios sobre la protección penal del medio ambiente en el ordenamiento jurídico español. Granada: Comares, 2005. p. 1-72.

BATISTA, Nilo. Introdução Crítica ao Direito Penal Brasileiro. 4. ed. Rio de Janeiro: Revan, 2001.

BECCARIA Cesare Bonesana. Dei delliti e delle pene (1764). Tradução: Lucia Guidicini e Alessandro Berti Contessa. Dos Delitos e das Penas. São Paulo: Martins Fontes, 1997.

BIANCHINI, Alice. Pressupostos Materiais Mínimos da Tutela Penal. São Paulo: Revista dos Tribunais, 2002.

BITENCOURT, Cezar Roberto. Falência da Pena de Prisão: Causas e alternativas. 2. ed. São Paulo: Saraiva, 2001.

BITENCOURT, Cezar Roberto. Juizados especiais criminais e alternativas à pena de prisão. 2. ed. Porto Alegre: Livraria do Advogado, 1996.

BUSTOS RAMÍREZ, Juan. Necesidad de la pena, función simbólica y bien jurídico medio ambiente. Pena Y Estado: La función simbólica del Derecho Penal, Barcelona, n. 1, p.101-110, 1991.

CADERNOS DIREITO GV: Pesquisa em Debate: Aplicação da Lei de Crimes contra o Sistema Financeiro pelos Tribunais Brasileiros. São Paulo: Direito GV, número 33, v. 7, n. 1, jan. 2010. Bimestral. Disponível em: $<$ http://www.direitogv.com.br/interna.aspx?PagId=HTKCNKWI\&IDCategory=4\&IDSubC ategory $=213>$. Acesso em: 21 nov. 2010. 
CALHAU. Lélio Braga. Efetividade da tutela penal do meio ambiente: a busca do "ponto de equilíbrio" em Direito Penal Ambiental. Revista Jus Vigilantibus. 2004. Disponível em: <http://jusvi.com/artigos/2221>. Acesso em: 13 nov. 2010.

CANCIO MELIÁ, Manuel; FEIJOO SÁNCHEZ, Bernardo. ¿Prevenir riesgos o confirmar normas? La teoría funcional de la pena de Günther Jakobs. Estudio Preliminar In: JAKOBS, Günther. La pena estatal: significado y finalidad. Tradução: Manuel Cancio Meliá e Bernardo Feijoo Sánchez. Madrid: Civitas, 2006. p. 15-81.

CARNELUTTI, Francesco. As misérias do processo penal. 2. ed. Campinas: Bookseller, 2002.

CARRARA, Francesco. Programa do curso de direito criminal: Parte geral. São Paulo: Saraiva, 1956.

COMPARATO, Fábio Konder. A afirmação histórica dos Direitos Humanos. 2. ed. São Paulo: Saraiva, 2001.

CORCOY BIDASOLO, Mirentxu. Delitos de peligro y protección de bienes jurídicopenales supraindividuales: Nuevas formas de delincuencia y reinterpretación de tipos penales clásicos. Valencia: Tirant lo Blanch, 1999.

CORCOY BIDASOLO, Mirentxu. Protección penal del Medio ambiente: Legitimidad y alcance. Competencia penal y administrativa en materia de Medio ambiente. In: CORCOY BIDASOLO, Mirentxu. Derecho Penal de la empresa. Navarra: Universidad Pública de Navarra, 2002. p. 615-649.

CORCOY BIDASOLO. Mirentxu. Los delitos relativos a la ordenación del territorio y el medio ambiente: una perspectiva criminológica. In: CORCOY BIDASOLO, Mirentxu y RUIDÍAZ GARCÍA, Carmen (coords.). Problemas criminológicos en las sociedades complejas. Universidad Pública de Navarra: Pamplona, 2000. p. 55-94.

CORRÊA JÚNIOR, Alceu; SHECAIRA, Sérgio Salomão. Teoria da pena: Finalidades, Direito Positivo, Jurisprudência e Outros Estudos de Ciência Criminal. São Paulo: Revista dos Tribunais, 2002.

COSTA JÚNIOR, Paulo José da. Direito penal ecológico. Rio de Janeiro: Forense, 1996.

COSTA, Helena Regina Lobo da. A dignidade humana: teorias de prevenção geral positiva. São Paulo: Revista dos Tribunais, 2008.

COSTA, Helena Regina Lobo da. Proteção Penal Ambiental: Viabilidade. Efetividade. Tutela por outros ramos do direito. São Paulo: Saraiva, 2010.

DELMANTO, Celso; DELMANTO, Roberto; DELMANTO JÚNIOR, Roberto; DELMANTO, Fabio M. de Almeida. Código Penal comentado: acompanhado de comentários, jurisprudência, súmulas em matéria penal e legislação complementar. 8. ed. São Paulo: Saraiva, 2010.

DERANI, Cristiane. Direito Ambiental Econômico. São Paulo: Max Limonad, 1997.

DIAS, Jorge de Figueiredo. Breves Considerações sobre o Fundamento, o Sentido e a Aplicação das Penas em Direito Penal Económico. In: COSTA, José de Faria; SILVA, Marco Antonio Marques da. Direito Penal Especial, Processo Penal e Direitos Fundamentais: Visão Luso-Brasileira. São Paulo: Quartier Latin, 2006. p. 57-72.

DIAS, Jorge de Figueiredo. Questões Fundamentais do Direito Penal revisitadas. São Paulo: Revista dos Tribunais, 1999. 
DÍEZ RIPOLLÉS, José Luis. El Derecho Penal Simbólico y los efectos de la pena. In: ZAPATERO, Luis Arroyo; NEUMANN, Ulfrid; MARTÍN, Adán Nieto (coords). Critica y Justificación del Derecho Penal en el Cambio de Siglo: El análisis crítico de la Escuela de Frankfurt. Cuenca: Ediciones de La Universidad de Castilla-la Mancha, 2003. p. $147-172$.

DOTTI, René Ariel. A tutela penal dos Interesses Coletivos. In: GRINOVER, Ada Pellegrini (coord.) A tutela dos Interesses Difusos. São Paulo: Max Limonad, 1999. p. 54-77.

DOTTI, René Ariel. Bases Alternativas para o Sistema de Penas. 2. ed. São Paulo: Revista dos Tribunais, 1998.

DOTTI, René Ariel. Curso de Direito Penal: Parte Geral. Rio de Janeiro: Forense, 2001.

FALCÓN Y TELLA, María José; FALCÓN Y TELLA, Fernando. Fundamento y Finalidad de la sanción: ¿Un derecho a castigar? Madrid: Marcial Pons, 2005.

FEIJOO SÁNCHEZ, Bernardo José. Sanciones para empresas por delitos contra el medio ambiente: Presupuestos dogmáticos y criterios de imputación para la intervención del Derecho Penal contra las empresas. Madrid: Civitas, 2002.

FERNANDES, Antônio Scarance. O consenso na justiça penal brasileira. 1998. Disponível em: $<$ http://www.direitoprocessual.org.br/dados/File/enciclopedia/artigos/processo_pena1/15\% 20FERNANDES, $\% 20$ Ant $\%$ C3\%B4nio $\% 20$ Scarance $\% 20$ -

$\% 20 \mathrm{O} \% 20$ consenso $\% 20$ na $\% 20 \mathrm{justi} \% \mathrm{C} 3 \% \mathrm{~A} 7 \mathrm{a} \% 20$ penal $\% 20$ brasileira.doc $>$. Acesso em: 25 jan. 2010.

FERRAJOLI, Luigi. Direito e Razão: Teoria do Garantismo Penal. Tradução: Ana Paula Zomer Sica, Fauzi Hassan Choukr, Juarez Tavares e Luiz Flávio Gomes. 2. ed. São Paulo: Revista dos Tribunais, 2006.

FERRARI, Eduardo Reale. A ilegitimidade da criminalização das condutas atentatórias ao meio ambiente. Liber discipulorum para Jorge de Figueiredo Dias, Coimbra, p. 11851203, 2003.

FERRARI, Eduardo Reale. Medidas de segurança e direito penal no estado democrático de direito. São Paulo: Revista dos Tribunais, 2001.

FERRARI, Eduardo Reale. Transcrição do Seminário. Cadernos Direito GV: Pesquisa em Debate. Aplicação da Lei de Crimes contra o Sistema Financeiro pelos Tribunais Brasileiros, São Paulo, número 33, v. 7, n. 1, p.61-66, jan. 2010. Bimestral. Disponível em: $<$ http://www.direitogv.com.br/interna.aspx?PagId=HTKCNKWI\&IDCategory=4\&IDSubC ategory $=213>$. Acesso em: 21 out. 2010.

FERRARI, Eduardo Reale; COSTA, Helena Regina Lobo da. Dos crimes contra o meio ambiente: Seção III - da Poluição e outros crimes ambientais (arts. 54 a 61). In: NETTO, Alamiro Velludo Salvador; SOUZA, Luciano Anderson de. (Coords.) Comentários à Lei de Crimes Ambientais: Lei no 9.605/1998. São Paulo: Quartier Latin, 2009. p. 241-270.

FERREIRA, Ivette Senise. A Lei n ${ }^{\circ}$ 9099/95 e o Direito Penal Ambiental. In: PITOMBO, Antônio Sérgio A. de Moraes. Juizados Especiais Criminais: Interpretação e crítica. São Paulo: Malheiros, 1997. p. 11-24.

FIGUEIREDO, Guilherme Gouvêa de. Crimes Ambientais à Luz do Conceito de Bem Jurídico-Penal: (des)criminalização, redação típica e (in)ofensividade. São Paulo: IBCCRIM, 2008. 
FIORILlO, Celso Antonio Pacheco; RODRIGUES, Marcelo Abelha. Manual de Direito Ambiental e Legislação Aplicável. São Paulo: Max Limonad, 1997.

FRAGOSO, Heleno Cláudio. Lições de Direito Penal: a nova parte geral. 9. ed. Rio de Janeiro: Forense, 1985.

FRANCO, Alberto Silva. Crimes Hediondos: Anotações sistemáticas à lei 8.072/90. 4. ed. São Paulo: Revista dos Tribunais, 2000.

FRANCO, Alberto Silva. Os perigos da dramatização da violência. Juízes para a democracia: Publicação oficial da Associação Juízes para a democracia, São Paulo, ano 1, n. $1, \quad$ p. $4, \quad$ nov. 1993. Disponível em: $<$ http://www.ajd.org.br/arquivos/publicacao/64_democracia01.pdf $>$. Acesso em: $10 \mathrm{abr}$. 2000 .

FREITAS, Gilberto Passos de. Ilícito penal ambiental e reparação do dano. São Paulo: Revista dos Tribunais, 2005.

FREITAS, Vladimir Passos de. Direito Administrativo e Meio Ambiente. 3. ed. Curitiba: Juruá, 2001.

FREITAS, Vladimir Passos de. Sanções administrativas e meio-ambiente. In: BENJAMIN, Antonio Herman. Dano Ambiental: Preservação, Reparação e Repressão. São Paulo: Revista dos Tribunais, 1993. p. 346-356.

FREITAS, Vladimir Passos de.; FREITAS, Gilberto Passos de. Crimes contra a natureza. 7. ed. São Paulo: Revista dos Tribunais, 2001.

GARCÍA DE ENTERRÍA, Eduardo. Curso de Derecho Administrativo. 2. vol. Madrid: Civitas, 1974.

GARCÍA-PABLOS DE MOLINA, Antonio. Criminologia: Introdução a seus Fundamentos Teóricos. São Paulo: Revista dos Tribunais, 1992.

GARCÍA-PABlos DE MOLINA, Antonio. Derecho Penal: Introducción. Madrid: Universidad Complutense. Facultad de Derecho. Servicio de Publicaciones, 1995.

GARLAND, David. A cultura do controle: crime e ordem social na sociedade contemporânea. Tradução: André Nascimento. Rio de Janeiro: Revan, 2008.

GIMBERNAT ORDEIG, Enrique. O futuro do Direito Penal. Tradução: Maurício Antonio Ribeiro Lopes. Barueri: Manole, 2004.

GOMES, Luiz Flávio. Penas e Medidas Alternativas à Prisão. São Paulo: Revista dos Tribunais, 1999.

GRACIA MARTÍN, Luis. Modernización del Derecho penal y Derecho penal del enemigo. Lima: Idemsa, 2007.

GRECO, Luís. A relação entre o direito penal e o direito administrativo no direito penal ambiental: uma introdução aos problemas da acessoriedade administrativa. Revista Brasileira de Ciências Criminais. v. 14, n. 58, p. 152-194, 2006.

GUARDIOLA LAGO, María Jesús. Responsabilidad penal de las personas jurídicas y alcance del art. 129 del Código Penal. Valencia: Tirant lo blanch, 2004.

GÜNTHER, Klaus. Crítica da Pena I. Revista Direito GV: 4, São Paulo, v. 2, n. 2, p.187204, jul-dez. 2006. Disponível em: $<$ http://www.direitogv.com.br/interna.aspx?PagId=HTKCNKWI\&IDCategory=1\&IDSubC ategory $=79>$. Acesso em: 06 jun. 2010. 
GÜNTHER, Klaus. Crítica da Pena II. Revista Direito GV: 5, São Paulo, v. 3, n. 1, p.137150, jan-jun. $2007 . \quad$ Disponível em: $<$ http://www.direitogv.com.br/interna.aspx?PagId=HTKCNKWI\&IDCategory=1\&IDSubC ategory=121>. Acesso em: 06 jun. 2010.

GUIRAO, Rafael Alcácer. Los fines del Derecho Penal: Una aproximación desde la filosofía política. Bogotá: Universidad Externado de Colombia, 2004.

HASSEMER, Winfried e MUÑOZ CONDE, Francisco. Responsabilidad por el producto en Derecho penal. Valencia: Tirant lo Blanch, 1995.

HASSEMER, Winfried. ¿Por qué y con qué fin se aplican las penas?: Sentido y fin de la sanción penal. Revista de derecho penal y criminología. Madrid, n. 3, p. 317-334, 1999.

HASSEMER, Winfried. A preservação do ambiente através do Direito Penal. Revista Brasileira de Ciências Criminais. São Paulo, v. 6, n. 22, p. 27-35, abr./jun. 1998.

HASSEMER, Winfried. Característica e Crises do Moderno Direito Penal. Revista Síntese de Direito Penal e Processual Penal. São Paulo, v. 3, n. 18, p.144-157, fev./mar. 2003.

HASSEMER, Winfried. Derecho Penal simbólico y protección de bienes jurídicos. Pena Y Estado: La función simbólica del Derecho Penal, Barcelona, n. 1, p.23-36, 1991.

HASSEMER, Winfried. Fundamentos del derecho penal. Tradução: Luis Alberto Arroyo Zapatero e Francisco Muñoz Conde. Barcelona: Bosch, 1984.

HASSEMER, Winfried. Introdução aos Fundamentos do Direito Penal. Tradução: Rodrigo Alflen da Silva. Porto Alegre: Sergio Antonio Fabris, 2005.

HASSEMER, Winfried; MUÑOZ CONDE, Francisco. Introducción a la Criminología y al Derecho Penal. Valencia: Tirant lo blanch, 1989.

HEGEL, Georg Wilhelm Friedrich. Princípios de Filosofia do Direito. Tradução: Orlando Vitorino. São Paulo: Martins Fontes, 1997.

JAKOBS, Günther. Derecho penal: Parte general. Fundamentos y teoría de la imputación. Tradução: Joaquin Cuello Contreras e Jose Luiz Serrano Gonzales de Murillo. 2. ed. Madrid: Marcial Pons, 1997.

JAKOBS, Günther. La pena estatal: significado y finalidad. Tradução: Manuel Cancio Meliá e Bernardo Feijoo Sánchez. Madrid: Civitas, 2006.

KANT, Immanuel. La Metafísica de las Costumbres. Madrid: Tecnos, 1989.

KELSEN, Hans. O que é justiça?: A Justiça, o Direito e a Política no espelho da ciência. Tradução: Luiz Carlos Borges. 3. ed. São Paulo: Martins Fontes, 2001.

LUISI, Luiz. Notas sobre a Responsabilidade Penal das Pessoas Jurídicas. In: PRADO, Luiz Regis. (coord.) Responsabilidade Penal da Pessoa Jurídica: Em defesa do princípio da imputação penal subjetiva. São Paulo: Revista dos Tribunais, 2001. p. 79-100

MACHADO, Maíra Rocha. Administrativização do Direito Penal Revisitada: O Exemplo dos Crimes Financeiros no Brasil. Revista Ultima Ratio, Rio de Janeiro, ano 3, n. 3, p. 89100, 2009.

MACHADO, Marta Rodriguez de Assis. Sociedade do Risco e Direito Penal: Uma avaliação de novas tendências político-criminais. São Paulo: Ibccrim, 2005. 
MATA BARRANCO, Norberto J. de la. Protección Penal del ambiente y accesoriedad administrativa: Tratamiento penal de comportamientos perjudiciales para el ambiente amparados en una autorización administrativa ilícita. Barcelona: Cedecs, 1996.

MAZZILli, Hugo Nigro. A Defesa dos Interesses Difusos em Juízo: Meio Ambiente. Consumidor. Patrimônio Cultural. Patrimônio Público e outros interesses. 20. ed. São Paulo: Saraiva, 2007.

MELlO, Celso Antônio Bandeira de. Curso de Direito Administrativo. 22.ed. São Paulo: Malheiros, 2007.

MILARÉ, Edis. Direito do ambiente. 3.ed. São Paulo: Revista dos Tribunais, 2004.

MIR PUIG, Santiago. Derecho penal en el Estado social y democrático de Derecho. Barcelona: Ariel, 1994.

MIR PUIG, Santiago. Derecho Penal: Parte General. 7. ed. Buenos Aires: Reppertor, 2007.

MIR PUIG, Santiago. El principio de proporcionalidad como fundamento constitucional de límites materiales del Derecho penal. In: CARBONELL MATEU, Juan Carlos; GONZÁLEZ CUSSAC, José Luis; BERENGUER, ORTS Enrique; CUERDA ARNAU, María Luisa (coords.) Constitución, derechos fundamentales y sistema penal: semblanzas y estudios con motivo del setenta aniversario del profesor Tomás Salvador Vives Antón. 2. v. Valencia: Tirant lo Blanch, 2009. p. 1357-1382.

MIR PUIG, Santiago. El sistema de Derecho Penal en la Europa actual. In: SILVA SÁNCHEZ, Jesús-María (ed.) Fundamentos de un sistema europeo del Derecho Penal: Libro-Homenaje a Claus Roxin. Barcelona: Bosch, 1995, p. 25-36.

MIR PUIG, Santiago. Función de la Pena y Teoría del Delito en el Estado Social y Democrático de Derecho. Barcelona: Bosch, 1976.

MIR PUIG, Santiago. Una tercera vía en materia de Responsabilidad Penal de las Personas Jurídicas. Revista Electrónica de Ciencia Penal y Criminología, n. 6, 2004. Disponível em: < http://criminet.ugr.es/recpc/06/recpc06-01.pdf >. Acesso em: 03 mar. 2009.

MÜLLER-TUCKFELD, Jens Christian. Ensayo para la abolición del Derecho Penal del Medio Ambiente. Tradução: Elena Iñigo Corroza, Nuria Pastor Muñoz, y Ramon Ragués i Vallès In: SILVA SÁNCHEZ, Jesús-María; ROMERO CASABONA, Carlos María. La Insostenible situación del Derecho Penal. Granada: Área de Derecho Penal de la Universidad Pompeu Fabra, 2000. p. 507-530.

MUÑOZ CONDE, Francisco. Introducción al Derecho Penal. Barcelona: Bosch, 1975.

PAIVA, Luiz Guilherme Mendes de. A Fábrica de penas: Racionalidade legislativa e a lei dos crimes hediondos. Rio de Janeiro: Revan, 2009.

PASCHOAL, Janaína Conceição. Breves apontamentos relativos ao instituto do plea bargaining no direito norte-americano. FMU Direito: Revista do curso de direito do Centro Universitário das Faculdades Metropolitanas Unidas. São Paulo. v. 15, n. 23, p. 115-126, 2001.

PASCHOAL, Janaína Conceição. Constituição, criminalização e direito penal mínimo. São Paulo: Revista dos Tribunais, 2003.

PASCOLATTI JÚNIOR, Ulisses Augusto. Da aplicação da pena: $1^{a}$ parte. Da aplicação da pena às pessoas físicas (arts. $6^{\circ}$ a 20). In: NETTO, Alamiro Velludo Salvador; SOUZA, 
Luciano Anderson de. (coords.) Comentários à Lei de Crimes Ambientais: Lei $\mathrm{n}^{\mathbf{0}}$ 9.605/1998. São Paulo: Quartier Latin, 2009. p. 51-88.

PAUL, Wolf. Megacriminalidad ecológica y Derecho ambiental simbólico. Pena y Estado: La función simbólica del Derecho Penal, Barcelona, n. 1, p.111-122, 1991.

PENA Y ESTADO: La función simbólica del Derecho Penal. Barcelona: PPU, n. 1, 1991.

PERALTA, José Milton. Prevención general positiva como respeto por el orden jurídico. InDret 2/2008: Revista para el Análisis del Derecho, 2008. Disponível em: $<$ http://www.indret.com>. Acesso em: 03 mar. 2009.

PIETRO, Maria Sylvia de. Direito Administrativo. 14. ed. São Paulo: Atlas, 2002.

PINTO, Inês Horta. Os efeitos do "direito penal europeu" nos sistemas sancionatórios dos estados-membros da União Europeia. In: COSTA, José de Faria; SILVA, Marco Antonio Marques da. Direito Penal Especial, Processo Penal e Direitos Fundamentais: Visão Luso-Brasileira. São Paulo: Quartier Latin, 2006. p. 821-852.

PRADO, Luiz Regis (Coord.). Responsabilidade Penal da Pessoa Jurídica: Em defesa do princípio da imputação penal subjetiva. São Paulo: Revista Dos Tribunais, 2001.

PRADO, Luiz Regis. Direito Penal do Ambiente: Meio Ambiente, Patrimônio Cultural, Ordenação do Território, Biossegurança (com análise da Lei 11.105/2005. São Paulo: Revista dos Tribunais, 2005.

PROJETO PRODES. Monitoramento da Floresta Amazônica Brasileira por Satélite. Disponível em: <http://www.obt.inpe.br/prodes/>. Acesso em: 23 set. 2010.

RAMÍREZ, Juan Bustos. Necesidad de la pena, función simbólica y bien jurídico medio ambiente. Pena y Estado: La función simbólica del Derecho Penal, Barcelona, n. 1, p.101$110,1991$.

REALE JÚNIOR, Miguel. A Lei de Crimes Ambientais. Revista Forense, Rio de Janeiro, v. 95, n. 345, p.121-127, 1999a.

REALE JÚNIOR, Miguel. Despenalização no Direito Penal Econômico: terceira via entre o crime e a infração administrativa? Revista Brasileira de Ciências Criminais, São Paulo, v. 7, n. 28, p.116-129, out/dez. 1999b.

REALE JÚNIOR, Miguel. Instituições de Direito Penal. Parte Geral. 1. vol. Rio de Janeiro: Forense, 2002.

REALE JÚNIOR, Miguel. Instituições de Direito Penal. Parte Geral. 3. ed. Rio de Janeiro: Forense, 2009.

REALE JÚNIOR, Miguel. Meio ambiente e direito penal brasileiro. Ciências Penais: Revista da Associação Brasileira de Professores de Ciências Penais, São Paulo, v. 2, ano 2, p.67-83, 2005.

REALE JÚNIOR, Miguel. Pena sem processo. In: PITOMBO, Antônio Sérgio A. de Moraes. Juizados Especiais Criminais: Interpretação e crítica. São Paulo: Malheiros, 1997. p. 25-32.

REALE JÚNIOR, Miguel. Responsabilidade Penal da Pessoa Jurídica. In: PRADO, Luiz Regis. (coord.) Responsabilidade Penal da Pessoa Jurídica: Em defesa do princípio da imputação penal subjetiva. São Paulo: Revista dos Tribunais, 2001. p. 137-139. 
REALE JÚNIOR, Miguel. Simplificação processual e desprezo ao direito penal. Ciências Penais: Revista da Associação Brasileira de Professores de Ciências Penais, São Paulo, v. 9, ano 5, p.289-310, 2008.

REALE JÚNIOR, Miguel; DOTTI, René Ariel; ANDREUCCI, Ricardo Antunes; PITOMBO, Sergio M. de Morais. Penas e Medidas de Segurança no Novo Código. Rio de Janeiro: Forense, 1985.

RODRIGUES, Anabela Maria Pinto de Miranda. Direito Penal do Ambiente: uma Aproximação ao Novo Direito Português. In: Revista de Direito Ambiental. São Paulo, vol.1, n.2, p. 14-24, abr./jun. 1996.

RODRIGUES, Fabíola Emilin. Direito Penal Ambiental e a Sociedade Atual. In: COSTA, José de Faria; SILVA, Marco Antonio Marques da. (coords.) Direito Penal Especial, Processo Penal e Direitos Fundamentais: Visão Luso-Brasileira. São Paulo: Quartier Latin, 2006. p. 962-997.

ROJAS, Ricardo Manuel. Las contradicciones del derecho penal. Buenos Aires: AdHoc, 2000.

ROXIN, Claus. Conclusiones finales. In: ZAPATERO, Luis Arroyo; NEUMANN, Ulfrid; MARTÍN, Adán Nieto. Critica y Justificación del Derecho Penal en el Cambio de Siglo: El análisis crítico de la Escuela de Frankfurt. Cuenca: Universidad de Castilla-la Mancha, 2003. p. 317-330.

ROXIN, Claus. Culpabilidad y Prevención en Derecho Penal. Tradução: Francisco Muñoz Conde. Madrid: Reus, 1981.

ROXIN, Claus. Derecho penal: Parte general. Tomo I. Fundamentos. La estructura de la teoría del delito. Tradução: Diego-Manuel Luzón Peña, Miguel Díaz y García Conlledo e Javier de Vicente Remesal. Madrid: Civitas, 1997.

SÁ, Alvino Augusto de. Crimes Ambientais: Ensaiando Algumas Reflexões ClínicoCriminológicas. In: SÁ, Alvino Augusto de; SHECAIRA, Sérgio Salomão (Orgs.). Criminologia e os Problemas da Atualidade. São Paulo: Atlas, 2008. p. 197215.

SALVADOR NETTO, Alamiro Velludo. Da aplicação da pena: $2^{\mathrm{a}}$ parte. Da aplicação da pena às pessoas jurídicas (arts. 21 a 24). In: NETTO, Alamiro Velludo Salvador; SOUZA, Luciano Anderson de. (coords.) Comentários à Lei de Crimes Ambientais: Lei $\mathrm{n}^{\mathrm{o}}$ 9.605/1998. São Paulo: Quartier Latin, 2009a. p. 89-122.

SALVADOR NETTO, Alamiro Velludo. Finalidades da Pena: Conceito Material de Delito e Sistema Penal Integral. São Paulo: Quartier Latin, 2009b.

SANGUINÉ, Odone. Função simbólica da pena. Revista Portuguesa de Ciência Criminal, Coimbra, v. 5, n. 1, p. 77-89, 1995.

SAYAGUÉS LASO, Enrique. Tratado de Derecho Administrativo. 4. ed. Montevideo: Barreiro Y Ramos, 1974.

SCHÜNEMANN, Bernd. La función del principio de culpabilidad en el Derecho penal preventivo. In: SCHÜNEMANN, Bernd (Org.). EI sistema moderno del Derecho penal: Cuestiones Fundamentales. Tradução: Jesús-María Silva Sánchez. Madrid: Tecnos, 1991. p. 147-178. 
SCHÜNEMANN, Bernd. Sobre la dogmática y la política criminal del Derecho penal del medio ambiente. In: SCHÜNEMANN, Bernd. Temas actuales y permanentes del Derecho penal después del milenio. Madrid: Tecnos, 2002. p. 203-223.

SÉRIE PENSANDO O DIREITO: Pena Mínima. Brasília: Ministério da Justiça, n. 17, 2009a. Disponível em: <http://portal.mj.gov.br/sal/main.asp?View $=\{329 D 6 E B 2-8 A B 0-$ 4606-B054-4CAD3C53EE73 \} >. Acesso em: 20 jan. 2010.

SÉRIE PENSANDO O DIREITO: Penas Alternativas. Brasília: Ministério da Justiça, n. 6 , 2009b. Disponível em: <http://portal.mj.gov.br/sal/main.asp?View=\{329D6EB2-8AB04606-B054-4CAD3C53EE73 \} >. Acesso em: 20 jan. 2010.

SGUBBI, Filippo. EI delito como riesgo social: Investigación sobre las opciones en la asignación de la ilegalidad penal. Tradução: Julio E. S. Virgolini. Buenos Aires: Ábaco, 1998.

SHECAIRA, Sérgio Salomão. Responsabilidade Penal da Pessoa Jurídica. 2. ed. São Paulo: Método, 2003.

SILVA SÁNCHEZ, Jesús-María e ORTIZ DE URBINA GIMENO, Iñigo. El art. 31.2 del Código penal: ¿Responsabilidad penal de las personas jurídicas o mero aseguramiento del pago de la pena de multa? InDret: Revista para el Análisis del Derecho, 2006. Disponível em: <http://www.indret.com>. Acesso em: 03 mar. 2009.

SILVA SÁNCHEZ, Jesús-María. ¿Protección penal del medio ambiente?: Texto y contexto del artículo 325 del Código Penal. La Ley: Tomo de jurisprudencia, Madrid, n. 3, p.1714-1725, 1997.

SILVA SÁNCHEZ, Jesús-María. Delitos contra el medio ambiente. Valencia: Tirant lo Blanch, 1999.

SILVA SÁNCHEZ, Jesús-María. Duras Penas. InDret Editorial: Revista para el Análisis del Derecho, 2008a. Disponível em: $<$ http://www.indret.com/pdf/editorial_indret_penal_2_2008.pdf $>$. Acesso em: 03 mar. 2009.

SILVA SÁNCHEZ, Jesús-María. Eficiência e Direito Penal. Tradução: Maurício Antonio Ribeiro Lopez. Barueri: Manole, 2004.

SILVA SÁNCHEZ, Jesús-María. La aplicación judicial de las consecuencias accesorias para las empresas. InDret 342: Revista para el Análisis del Derecho, 2006. Disponível em: $<$ http://www.indret.com/pdf/342_es2.pdf>. Acesso em: 02 ago. 2009.

SILVA SÁNCHEZ, Jesús-María. La expansión del Derecho penal: Aspectos de la Política criminal en las sociedades postindustriales. 2. ed. Montevideo: B de F, 2008b.

SILVA SÁNCHEZ, Jesús-María. La responsabilidad penal de las personas jurídicas y las consecuencias accesorias del art. 129 del Código penal. Manuales de Formación Continuada: Derecho penal económico, Madrid, n. 14, p.308-312, 2001.

SILVA SÁNCHEZ, Jesús-María. Perspectivas sobre la política criminal moderna. Buenos Aires: Ábaco, 1998.

SILVA SÁNCHEZ, Jesús-María. Aproximación al Derecho penal contemporáneo. 2. ed. Barcelona: Bosch, 2002.

SILVA, José Afonso da. Direito Ambiental Constitucional. 4. ed. São Paulo: Malheiros, 2002. 
SILVA, Virgílio Afonso da. O proporcional e o razoável. Revista dos Tribunais. São Paulo, v. 798, n. 91, p. 23-50, abr. 2002.

SILVEIRA, Renato de M. Jorge. Direito penal supra-individual: interesses difusos. São Paulo: Revista dos Tribunais, 2003.

SIRVInSKAS, Luís Paulo. Tutela Penal do Meio Ambiente. Breves Considerações Atinentes à Lei n. 9.605 de 12-2-1998. São Paulo: Saraiva, 1998.

SISPENAS. Disponível em: < http://portal.mj.gov.br/data/Pages/MJCCFB3C67ITEMID3C94F3D79C204705BC8E84F8 712478D1PTBRIE.htm>. Acesso em: 21 out. 2010.

SOTO NAVARRO, Susana. La protección de los Bienes Colectivos en la Sociedad Moderna. Granada: Comares, 2003.

STRATENWERTH, Günther. ¿Qué aporta la teoría de los fines de la pena? Tradução: Marcelo A. Sancinetti. Bogotá: Universidad Externado de Colombia, Centro de Investigaciones de Derecho Penal y Filosofía del Derecho, 1996.

TIEDEMANN, Klaus. Poder económico y delito: Introducción al derecho penal económico y de la empresa. Tradução: Amelia Mantilla Villegas. Barcelona: Ariel, 1985.

TOBIAS BARRETO. Obras completas: Menores e Loucos e Fundamento do Direito de Punir. v. 5. Rio de Janeiro: EGE, 1926

TORON, Alberto Zacharias. Crimes Hediondos: O Mito da Repressão Penal. São Paulo: Revista dos Tribunais, 1996.

VICENTE MARTÍNEZ, Rosario de. Sanciones y reparación en el Derecho penal económico. In: FERNÁNDEZ, José Ramón Serrano-piedecasas; DEMETRIO CRESPO, Eduardo. Cuestiones actuales de derecho penal económico. Madrid: Colex, 2008. p. 18722

VIEIRA, Ana Carolina Alfinito. As Penas Alternativas e a Lei 7492/86: Um Estudo sobre a Substituição da Pena de prisão em condenações por Crimes Financeiros. Cadernos Direito GV: Pesquisa em Debate. Aplicação da Lei de Crimes contra o Sistema Financeiro pelos Tribunais Brasileiros, São Paulo, número 33, v. 7, n. 1, p.85-92, jan. 2010. Bimestral. Disponível em: $<$ http://www.direitogv.com.br/interna.aspx?PagId=HTKCNKWI\&IDCategory=4\&IDSubC ategory=213>. Acesso em: 21 out. 2010.

VON HIRSCH, Andrew. Retribución y prevención como elementos de justificación de la pena. In: ZAPATERO, Luis Arroyo; NEUMANN, Ulfrid; MARTÍN, Adán Nieto. Critica y Justificación del Derecho Penal en el Cambio de Siglo: El análisis crítico de la Escuela de Frankfurt. Cuenca: Universidad de Castilla-la Mancha, 2003. p. 125-146.

VON LISZT, Franz. La idea del fin en el Derecho Penal: programa de la Universidad de Marburgo. (1882) Tradução: Carlos Pérez del Valle, Granada: Comares, 1995.

WELZEL, Hans. O novo sistema jurídico-penal: uma introdução à doutrina da ação finalista. Tradução: Luiz Régis Prado. São Paulo: Revista dos Tribunais, 2001.

WOLTER, Jürgen; FREUND, Georg. El sistema integral del derecho penal: delito, determinación de la pena y proceso penal. Madrid: Marcial Pons, 2004.

ZAFFARONI, Eugenio Raúl; PIERANGELI, José Henrique. Manual de direito penal brasileiro: parte geral. v. 1. 6. ed. São Paulo: Revista dos Tribunais, 2006. 


\section{Legislação}

BRASIL. Código de Defesa do Consumidor. Lei n. 8.078, de 11 de setembro de 1990. Disponível em: <http://www.planalto.gov.br/ccivil_03/Leis/L8078.htm>.

BRASIL. Código Florestal. Lei n. 4.771, de 15 de setembro de 1965. Disponível em: $<$ http://www.planalto.gov.br/ccivil_03/Leis/L4771.htm >.

BRASIL. Código Penal. Decreto-Lei n. 2.848, de 7 de dezembro de 1940. Disponível em: $<$ http://www.planalto.gov.br/ccivil/Decreto-Lei/Del2848.htm>.

BRASIL. Constituição (1988). Constituição da República Federativa do Brasil. Brasília, DF: Senado Federal, 1988.

BRASIL. Decreto n. 6.514, de 22 de julho de 2008. Disponível em: <http://www.planalto.gov.br/ccivil_03/_Ato2007-2010/2008/Decreto/D6514.htm>.

BRASIL. Emenda Constitucional n. 45, de 30 de dezembro de 2004. Disponível em: $<$ http://www.planalto.gov.br/ccivil_03/constituicao/emendas/emc/emc45.htm>.

BRASIL. Lei de Ação Civil Pública. Lei n. 7.347, de 24 de julho de 1985. Disponível em: $<$ http://www.planalto.gov.br/ccivil_03/Leis/L7347orig.htm>.

BRASIL. Lei de Crimes Ambientais. Lei n. 9.605, de 12 de fevereiro de 1998. Disponível em: <http://www.planalto.gov.br/ccivil_03/Leis/L9605.htm>.

BRASIL. Lei n. 5.197, de 3 de janeiro de 1967. Disponível em: $<$ http://www.planalto.gov.br/ccivil_03/Leis/L5197.htm>.

BRASIL. Lei n. 6.513, de 20 de dezembro de 1977. Disponível em: $<$ http://www.planalto.gov.br/ccivil_03/Leis/L6513.htm>.

BRASIL. Lei n. 6.766, de 19 de dezembro de 1979. Disponível em: $<$ http://www.planalto.gov.br/ccivil_03/Leis/L6766.htm>.

BRASIL. Lei n. 6.894, de 16 de dezembro de 1980. Disponível em: $<$ http://www.planalto.gov.br/ccivil/leis/1980-1988/L6894.htm>.

BRASIL. Lei n. 7.542, de 26 de setembro de 1986. Disponível em: $<$ http://www.planalto.gov.br/ccivil/leis/L7542.htm>.

BRASIL. Lei n. 7.643, de 18 de dezembro de 1987. Disponível em: $<$ http://www.planalto.gov.br/ccivil_03/Leis/L7643.htm>.

BRASIL. Lei n. 7.802, de 11 de julho de 1989. Disponível em: $<$ http://www.planalto.gov.br/ccivil/leis/L7802.htm>.

BRASIL. Lei n. 8.176, de 8 de fevereiro de 1991. Disponível em: $<$ http://www.planalto.gov.br/ccivil/leis/L8176.htm>.

BRASIL. Lei n. 9.099, de 26 de setembro de 1995. Disponível em: $<$ http://www.planalto.gov.br/ccivil/leis/L9099.htm>.

BRASIL. Plano Nacional de Gerenciamento Costeiro. Lei n. 7.661, de 16 de maio de 1988. Disponível em: < http://www.planalto.gov.br/ccivil_03/Leis/L7661.htm>.

BRASIL. Política Nacional do Meio Ambiente. Lei n. 6.938, de 31 de agosto de 1981. Disponível em: <http://www.planalto.gov.br/ccivil_03/Leis/L6938.htm>. 
Código de Hammurabi. Disponível em: <http://distritos.telepolis.com/1395/lib/ebooks/Codigo_de_Hammurabi.pdf>.

ESPANHA. Código Penal. Ley Orgânica n. 10, de 23 de novembro de 1995. Disponível em: <http://www.boe.es/aeboe/consultas/bases_datos/doc.php?id=BOE-A-1995-25444>

FRANÇA. Declaração dos Direitos do Homem e do Cidadão. 26 de agosto de 1789. Disponível em: <http://www.direitoshumanos.usp.br/index.php/Documentos-anteriores$\% \mathrm{C} 3 \% \mathrm{~A} 0$-cria\%C3\%A7\%C3\%A3o-da-Sociedade-das-Na\%C3\%A7\%C3\%B5esat\%C3\%A9-1919/declaracao-de-direitos-do-homem-e-do-cidadao-1789.html>.

ORGANIZAÇÃO DAS NAÇÕES UNIDAS. Declaração de Estocolmo sobre o Meio Ambiente Humano. 1972. Disponível em: http://www.dhnet.org.br/direitos/sip/onu/doc/estoc72.htm.

ORGANIZAÇÃO DAS NAÇÕES UNIDAS. Declaração do Rio sobre Meio Ambiente e Desenvolvimento. $1992 . \quad$ Disponível em: $<$ http://www.mma.gov.br/port/sdi/ea/documentos/convs/decl_rio92.pdf $>$.

ORGANIZAÇÃO DAS NAÇÕES UNIDAS. Declaração Universal dos Direitos Humanos. 10 de dezembro de 1948. Disponível em: $<$ http://www.mj.gov.br/sedh/ct/legis_intern/ddh_bib_inter_universal.htm>.

ORGANIZAÇÃO DAS NAÇÕES UNIDAS. Pacto Internacional de Direitos Civis e Políticos. 19 de dezembro de 1966. Disponível em: $<$ http://www.dhnet.org.br/direitos/sip/onu/doc/pacto2.htm>.

ORGANIZAÇÃO DAS NAÇÕES UNIDAS. Regras Mínimas das Nações Unidas para a Elaboração de Medidas não Privativas de Liberdade (Regras de Tóquio). 14 de dezembro de $1990 . \quad$ Disponível em: $<$ http://www.lgdh.org/Regras\%20Minimas\%20das\%20Nacoes\%20Unidas\%20Regras\%20 de\%20Toquio.htm $>$.

\section{Julgados}

AMAZONAS. Tribunal Regional Federal da $1^{\text {a }}$ Região. Apelação Criminal n. 2000.38.00.018570-6. Relator: Desembargador Federal Cândido Ribeiro. Pendente de julgamento. Disponível em $<$ http://www.trf1.jus.br/Processos/ProcessosTRF/>. Acesso em 02.12.2010.

BRASIL. Superior Tribunal de Justiça. Agravo Regimental em Recurso Especial n. 695463/PA. Relator: Ministro Arnaldo Esteves Lima. J. em 06/09/2005. Disponível em: $<$ http://www.stj.jus.br>. Acesso em: 25 out. 2010.

BRASIL. Superior Tribunal de Justiça. Agravo Regimental no Recurso Especial n. 849417/SP. Relator: Ministro Arnaldo Esteves Lima. J. em 03/09/2009. Disponível em: $<$ http://www.stj.jus.br>. Acesso em: 25 out. 2010.

BRASIL. Superior Tribunal de Justiça. Agravo Regimental no Recurso Especial n. 984569/PA. Relator: Ministro Francisco Falcão. J. em 04/12/2007. Disponível em: $<$ http://www.stj.jus.br>. Acesso em: 25 out. 2010.

BRASIL. Superior Tribunal de Justiça. Agravo Regimental No Recurso Especial n. 939151/MG. Relator: Ministro Humberto Martins. J. em 13/11/2007. Disponível em: <http://www.stj.jus.br>. Acesso em: 25 out. 2010. 
BRASIL. Superior Tribunal de Justiça. Agravo Regimental no Recurso Especial n. 704209/PA. Relator: Ministro Hamilton Carvalhido. J. em 02/02/2006. Disponível em: $<$ http://www.stj.jus.br>. Acesso em: 25 out. 2010.

BRASIL. Superior Tribunal de Justiça. Agravo Regimental no Recurso Especial n. 596716/TO. Relator: Ministro Paulo Medina. J. em 16/12/2004. Disponível em: $<$ http://www.stj.jus.br>. Acesso em: 25 out. 2010.

BRASIL. Superior Tribunal de Justiça. Agravo Regimental no Recurso Especial n. 480166/TO. Relator: Ministro Hamilton Carvalhido. J. em 23/03/2004. Disponível em: $<$ http://www.stj.jus.br>. Acesso em: 25 out. 2010.

BRASIL. Superior Tribunal de Justiça. Agravo Regimental no Recurso Especial n. 998993/RS. Relator: Ministro Paulo Gallotti. J. em 05/03/2009. Disponível em: $<$ http://www.stj.jus.br>. Acesso em: 25 out. 2010.

BRASIL. Superior Tribunal de Justiça. Embargos de Declaração no Recurso Especial n. 622724/SC. Relator: Ministro Felix Fischer. J. em 02/08/2005. Disponível em: $<$ http://www.stj.jus.br>. Acesso em: 25 out. 2010.

BRASIL. Superior Tribunal de Justiça. Habeas Corpus n. 49.607/SP. Relator: Ministro Gilson Dipp. J. em 29/06/2006. Disponível em: <http://www.stj.jus.br>. Acesso em: 25 out. 2010.

BRASIL. Superior Tribunal de Justiça. Habeas Corpus n. 82.911/MG. Relator: Ministro Arnaldo Esteves. J. em 05/05/2009. Disponível em: <http://www.stj.jus.br>. Acesso em: 25 out. 2010.

BRASIL. Superior Tribunal de Justiça. n. 596752/TO. Relator: Ministro Gilson Dipp. J. em 10/02/2004. Disponível em: <http://www.stj.jus.br>. Acesso em: 25 out. 2010.

BRASIL. Superior Tribunal de Justiça. Recurso Especial n. 1006383/PA. Relator: Ministro Felix Fischer. J. em 21/08/2008. Disponível em: <http://www.stj.jus.br>. Acesso em: 25 out. 2010.

BRASIL. Superior Tribunal de Justiça. Recurso Especial n. 1011333/MG. Relatora: Ministra Eliana Calmon. J. em 16/09/2008. Disponível em: $<$ http://www.stj.jus.br>. Acesso em: 25 out. 2010.

BRASIL. Superior Tribunal de Justiça. Recurso Especial n. 1015133/MT. Relator: Eliana Calmon. J. em 02/03/2010. Disponível em: <http://www.stj.jus.br>. Acesso em: 25 out. 2010.

BRASIL. Superior Tribunal de Justiça. Recurso Especial n. 1033958/DF. Relator: Ministro José Delgado. J. em 03/06/2008. Disponível em: <http://www.stj.jus.br>. Acesso em: 25 out. 2010.

BRASIL. Superior Tribunal de Justiça. Recurso Especial n. 1049822/RS. Relator: Ministro Francisco Falcão. J. em 23/04/2009. Disponível em: <http://www.stj.jus.br $>$. Acesso em: 25 out. 2010.

BRASIL. Superior Tribunal de Justiça. Recurso Especial n. 1057292/PR. Relator: Ministro Francisco Falcão. J. em 17/06/2008. Disponível em: <http://www.stj.jus.br>. Acesso em: 25 out. 2010.

BRASIL. Superior Tribunal de Justiça. Recurso Especial n. 1080613/PR. Relatora: Ministra Denise Arruda. J. em 23/06/2009. Disponível em: $<$ http://www.stj.jus.br>. Acesso em: 25 out. 2010. 
BRASIL. Superior Tribunal de Justiça. Recurso Especial n. 1091486/RO. Relatora: Ministra Denise Arruda. J. em 02/04/2009. Disponível em: $<$ http://www.stj.jus.br>. Acesso em: 25 out. 2010.

BRASIL. Superior Tribunal de Justiça. Recurso Especial n. 1102193/RS. Relator: Ministro Mauro Campbell Marques. J. em 16/12/2008. Disponível em: <http://www.stj.jus.br>. Acesso em: 25 out. 2010.

BRASIL. Superior Tribunal de Justiça. Recurso Especial n. 1109333/SC. Relator: Ministro Francisco Falcão. J. em 14/04/2009. Disponível em: <http://www.stj.jus.br>. Acesso em: 25 out. 2010.

BRASIL. Superior Tribunal de Justiça. Recurso Especial n. 1115916/MG. Relator: Ministro Humberto Martins. J. em 01/09/2009. Disponível em: $<$ http://www.stj.jus.br>. Acesso em: 25 out. 2010.

BRASIL. Superior Tribunal de Justiça. Recurso Especial n. 1138591/RJ. Relator: Ministro Castro Meira. J. em 22/09/2009. Disponível em: <http://www.stj.jus.br>. Acesso em: 25 out. 2010.

BRASIL. Superior Tribunal de Justiça. Recurso Especial n. 1154538/SC. Relator: Ministro Felix Fischer. J. em 05/08/2010. Disponível em: <http://www.stj.jus.br>. Acesso em: 25 out. 2010.

BRASIL. Superior Tribunal de Justiça. Recurso Especial n. 130731/SP. Relator: Ministro Francisco Peçanha Martins. J. em 15/04/2004. Disponível em: <http://www.stj.jus.br>. Acesso em: 25 out. 2010.

BRASIL. Superior Tribunal de Justiça. Recurso Especial n. 172516/RS. Relator: Ministro Jorge Scartezzini. J. em 04/11/1999. Disponível em: <http://www.stj.jus.br>. Acesso em: 25 out. 2010.

BRASIL. Superior Tribunal de Justiça. Recurso Especial n. 182847/RS. Relator: Ministro Fernando Gonçalves. J. em 09/03/1999. Disponível em: <http://www.stj.jus.br>. Acesso em: 25 out. 2010 .

BRASIL. Superior Tribunal de Justiça. Recurso Especial n. 261371/SP. Relator: Ministro Fernando Gonçalves. J. em 15/10/2002. Disponível em: <http://www.stj.jus.br>. Acesso em: 25 out. 2010 .

BRASIL. Superior Tribunal de Justiça. Recurso Especial n. 26383/AM. Relator: Ministro Luiz Vicente Cernicchiaro. J. em 13/05/1997. Disponível em: <http://www.stj.jus.br>. Acesso em: 25 out. 2010.

BRASIL. Superior Tribunal de Justiça. Recurso Especial n. 331929/SP. Relator Ministro Felix Fischer. J. em 17/09/2002. Disponível em: <http://www.stj.jus.br>. Acesso em: 25 out. 2010.

BRASIL. Superior Tribunal de Justiça. Recurso Especial n. 404239/PR. Relator: Ministro Ruy Rosado de Aguiar. J. em 26/11/2002. Disponível em: <http://www.stj.jus.br>. Acesso em: 25 out. 2010.

BRASIL. Superior Tribunal de Justiça. Recurso Especial n. 416387/RS. Relator: Ministro Gilson Dipp. J. em 03/09/2002. Disponível em: <http://www.stj.jus.br>. Acesso em: 25 out. 2010. 
BRASIL. Superior Tribunal de Justiça. Recurso Especial n. 420044/RS. Relator: Ministro José Arnaldo da Fonseca. J. em 03/04/2003. Disponível em: <http://www.stj.jus.br>. Acesso em: 25 out. 2010.

BRASIL. Superior Tribunal de Justiça. Recurso Especial n. 427757/SC. Relator: Ministro Hamilton Carvalhido. J. em 29/11/2007. Disponível em: <http://www.stj.jus.br $>$. Acesso em: 25 out. 2010.

BRASIL. Superior Tribunal de Justiça. Recurso Especial n. 433369/RS. Relator: Ministro Fernando Gonçalves. J. em 06/02/2003. Disponível em: <http://www.stj.jus.br>. Acesso em: 25 out. 2010.

BRASIL. Superior Tribunal de Justiça. Recurso Especial n. 437959/TO. Relator: Ministro Paulo Medina. J. em 09/09/2003. Disponível em: <http://www.stj.jus.br>. Acesso em: 25 out. 2010.

BRASIL. Superior Tribunal de Justiça. Recurso Especial n. 439105/TO. Relator: Ministro Arnaldo Esteves Lima. J. em 12/04/2005. Disponível em: <http://www.stj.jus.br>. Acesso em: 25 out. 2010.

BRASIL. Superior Tribunal de Justiça. Recurso Especial n. 440986/SP. Relator: Ministro Felix Fischer. J. em 21/10/2003. Disponível em: <http://www.stj.jus.br>. Acesso em: 25 out. 2010.

BRASIL. Superior Tribunal de Justiça. Recurso Especial n. 446432/RS. Relator: Ministro José Arnaldo da Fonseca. J. em 15/05/2003. Disponível em: <http://www.stj.jus.br>. Acesso em: 25 out. 2010.

BRASIL. Superior Tribunal de Justiça. Recurso Especial n. 447639/PR. Relator: Ministro José Delgado. J. em 07/11/2002. Disponível em: <http://www.stj.jus.br $>$. Acesso em: 25 out. 2010.

BRASIL. Superior Tribunal de Justiça. Recurso Especial n. 480373/TO. Relatora: Ministra Laurita Vaz. J. em 18/12/2003. Disponível em: <http://www.stj.jus.br>. Acesso em: 25 out. 2010.

BRASIL. Superior Tribunal de Justiça. Recurso Especial n. 480406/TO. Relatora: Ministra Laurita Vaz. J. em 18/12/2003. Disponível em: <http://www.stj.jus.br>. Acesso em: 25 out. 2010.

BRASIL. Superior Tribunal de Justiça. Recurso Especial n. 480411/TO. Relator: Ministro José Arnaldo da Fonseca. J. em 04/09/2003. Disponível em: <http://www.stj.jus.br $>$. Acesso em: 25 out. 2010.

BRASIL. Superior Tribunal de Justiça. Recurso Especial n. 480419/TO. Relator: Ministra Laurita Vaz. J. em 11/11/2003. Disponível em: <http://www.stj.jus.br>. Acesso em: 25 out. 2010.

BRASIL. Superior Tribunal de Justiça. Recurso Especial n. 480474/TO. Relator: Ministra Laurita Vaz. J. em 13/05/2003. Disponível em: <http://www.stj.jus.br>. Acesso em: 25 out. 2010 .

BRASIL. Superior Tribunal de Justiça. Recurso Especial n. 480484/TO. Relator: Ministro Hamilton Carvalhido. J. em 18/11/2003. Disponível em: <http://www.stj.jus.br>. Acesso em: 25 out. 2010. 
BRASIL. Superior Tribunal de Justiça. Recurso Especial n. 485740/TO. Relator: Ministro Arnaldo Esteves Lima. J. em 19/04/2005. Disponível em: <http://www.stj.jus.br>. Acesso em: 25 out. 2010 .

BRASIL. Superior Tribunal de Justiça. Recurso Especial n. 499065/RS. Relatora: Ministra Laurita Vaz. J. em 16/09/2003. Disponível em: <http://www.stj.jus.br>. Acesso em: 25 out. 2010 .

BRASIL. Superior Tribunal de Justiça. Recurso Especial n. 50486/RS. Relator: Ministro Luiz Vicente Cernicchiaro. J. em 30/08/1994. Disponível em: <http://www.stj.jus.br>. Acesso em: 25 out. 2010.

BRASIL. Superior Tribunal de Justiça. Recurso Especial n. 505841/AM. Relator: Ministro Gilson Dipp. J. em 26/08/2003. Disponível em: <http://www.stj.jus.br>. Acesso em: 25 out. 2010.

BRASIL. Superior Tribunal de Justiça. Recurso Especial n. 506178/TO. Relator: Ministro Gilson Dipp. J. em 05/08/2003. Disponível em: <http://www.stj.jus.br>. Acesso em: 25 out. 2010.

BRASIL. Superior Tribunal de Justiça. Recurso Especial n. 506180/TO. Relator: Ministro Felix Fischer. J. em 17/06/2003. Disponível em: <http://www.stj.jus.br>. Acesso em: 25 out. 2010.

BRASIL. Superior Tribunal de Justiça. Recurso Especial n. 506181/TO. Relator: Ministro Gilson Dipp. J. em 05/08/2003. Disponível em: <http://www.stj.jus.br>. Acesso em: 25 out. 2010.

BRASIL. Superior Tribunal de Justiça. Recurso Especial n. 512496/MG. Relator: Ministro Felix Fischer. J. em 21/10/2003. Disponível em: <http://www.stj.jus.br>. Acesso em: 25 out. 2010.

BRASIL. Superior Tribunal de Justiça. Recurso Especial n. 539189/SC. Relator: Ministro José Delgado. J. em 11/05/2004. Disponível em: <http://www.stj.jus.br $>$. Acesso em: 25 out. 2010.

BRASIL. Superior Tribunal de Justiça. Recurso Especial n. 547047/SP. Relator: Ministro Gilson Dipp. J. em 07/10/2003. Disponível em: <http://www.stj.jus.br>. Acesso em: 25 out. 2010.

BRASIL. Superior Tribunal de Justiça. Recurso Especial n. 549721/TO. Relator: Ministro Gilson Dipp. J. em 18/11/2003. Disponível em: <http://www.stj.jus.br>. Acesso em: 25 out. 2010.

BRASIL. Superior Tribunal de Justiça. Recurso Especial n. 562375/TO. Relator: Ministro Arnaldo Esteves Lima. J. em 12/04/2005. Disponível em: <http://www.stj.jus.br>. Acesso em: 25 out. 2010 .

BRASIL. Superior Tribunal de Justiça. Recurso Especial n. 564960/SC. Relator: Ministro Gilson Dipp. J. em 02/06/2005. Disponível em: <http://www.stj.jus.br $>$. Acesso em: 25 out. 2010.

BRASIL. Superior Tribunal de Justiça. Recurso Especial n. 565099/TO. Relator: Ministro Felix Fischer. J. em 03/08/2004. Disponível em: <http://www.stj.jus.br>. Acesso em: 25 out. 2010. 
BRASIL. Superior Tribunal de Justiça. Recurso Especial n. 566076/DF. Relator: Ministro Felix Fischer. J. em 04/12/2003. Disponível em: <http://www.stj.jus.br>. Acesso em: 25 out. 2010.

BRASIL. Superior Tribunal de Justiça. Recurso Especial n. 578797/RS. Relator: Ministro Luiz Fux. J. em 05/08/2004. Disponível em: <http://www.stj.jus.br>. Acesso em: 25 out. 2010.

BRASIL. Superior Tribunal de Justiça. Recurso Especial n. 579726/TO. Relator: Ministro Felix Fischer. J. em 09/12/2003. Disponível em: <http://www.stj.jus.br>. Acesso em: 25 out. 2010.

BRASIL. Superior Tribunal de Justiça. Recurso Especial n. 579738/TO. Relator: Ministro Arnaldo Esteves Lima. J. em 12/04/2005. Disponível em: <http://www.stj.jus.br>. Acesso em: 25 out. 2010 .

BRASIL. Superior Tribunal de Justiça. Recurso Especial n. 585680/TO. Relator: Ministro Gilson Dipp. J. em 10/02/2004. Disponível em: <http://www.stj.jus.br>. Acesso em: 25 out. 2010.

BRASIL. Superior Tribunal de Justiça. Recurso Especial n. 588022/SC. Relator: José Delgado. J. em 17/02/2004. Disponível em: <http://www.stj.jus.br>. Acesso em: 25 out. 2010.

BRASIL. Superior Tribunal de Justiça. Recurso Especial n. 591091/TO. Relator: Ministro José Arnaldo da Fonseca. J. em 16/03/2004. Disponível em: <http://www.stj.jus.br>. Acesso em: 25 out. 2010.

BRASIL. Superior Tribunal de Justiça. Recurso Especial n. 591998/TO. Relator: Ministro Felix Fischer. J. em 10/02/2004. Disponível em: <http://www.stj.jus.br>. Acesso em: 25 out. 2010.

BRASIL. Superior Tribunal de Justiça. Recurso Especial n. 592003/TO. Relator: Ministro José Arnaldo da Fonseca. J. em 05/02/2004. Disponível em: <http://www.stj.jus.br>. Acesso em: 25 out. 2010.

BRASIL. Superior Tribunal de Justiça. Recurso Especial n. 592009/TO. Relator: Ministro Arnaldo Esteves Lima. J. em 12/04/2005. Disponível em: <http://www.stj.jus.br>. Acesso em: 25 out. 2010.

BRASIL. Superior Tribunal de Justiça. Recurso Especial n. 592012/TO. Relator: Ministro Arnaldo Esteves Lima. J. em 12/04/2005. Disponível em: <http://www.stj.jus.br>. Acesso em: 25 out. 2010 .

BRASIL. Superior Tribunal de Justiça. Recurso Especial n. 592017/TO. Relator: Ministro Gilson Dipp. J. em 10/02/2004. Disponível em: <http://www.stj.jus.br>. Acesso em: 25 out. 2010.

BRASIL. Superior Tribunal de Justiça. Recurso Especial n. 592932/TO. Relator: Ministro Gilson Dipp. J. em 18/12/2003. Disponível em: <http://www.stj.jus.br>. Acesso em: 25 out. 2010.

BRASIL. Superior Tribunal de Justiça. Recurso Especial n. 599052/TO. Relator: Ministro José Arnaldo da Fonseca. J. em 23/03/2004. Disponível em: <http://www.stj.jus.br>. Acesso em: 25 out. 2010. 
BRASIL. Superior Tribunal de Justiça. Recurso Especial n. 601154/TO. Relator: Ministro Hamilton Carvalhido. J. em 27/04/2004. Disponível em: <http://www.stj.jus.br $>$. Acesso em: 25 out. 2010 .

BRASIL. Superior Tribunal de Justiça. Recurso Especial n. 602373/TO. Relator: Ministro Hamilton Carvalhido. J. em 27/04/2004. Disponível em: <http://www.stj.jus.br $>$. Acesso em: 25 out. 2010.

BRASIL. Superior Tribunal de Justiça. Recurso Especial n. 604186/TO. Relator: Ministro Gilson Dipp. J. em 01/04/2004. Disponível em: <http://www.stj.jus.br>. Acesso em: 25 out. 2010.

BRASIL. Superior Tribunal de Justiça. Recurso Especial n. 605343/PR. Relator: Ministro Felix Fischer. J. em 02/12/2004. Disponível em: <http://www.stj.jus.br>. Acesso em: 25 out. 2010.

BRASIL. Superior Tribunal de Justiça. Recurso Especial n. 607943/DF. Relatora: Ministra Laurita Vaz. J. em 17/11/2005. Disponível em: <http://www.stj.jus.br>. Acesso em: 25 out. 2010 .

BRASIL. Superior Tribunal de Justiça. Recurso Especial n. 610015/TO. Relator: Ministro Felix Fischer. J. em 06/05/2004. Disponível em: $<$ http://www.stj.jus.br $>$. Acesso em: 25 out. 2010.

BRASIL. Superior Tribunal de Justiça. Recurso Especial n. 610220/TO. Relator: Ministro Gilson Dipp. J. em 25/05/2004. Disponível em: <http://www.stj.jus.br>. Acesso em: 25 out. 2010.

BRASIL. Superior Tribunal de Justiça. Recurso Especial n. 611864/SP. Relator: Ministro José Arnaldo da Fonseca. J. em 25/05/2004. Disponível em: <http://www.stj.jus.br>. Acesso em: 25 out. 2010.

BRASIL. Superior Tribunal de Justiça. Recurso Especial n. 620819/TO. Relator: Ministro Gilson Dipp. J. em 17/06/2004. Disponível em: <http://www.stj.jus.br>. Acesso em: 25 out. 2010.

BRASIL. Superior Tribunal de Justiça. Recurso Especial n. 622707/SC. Relatora: Ministra Eliana Calmon. J. em 02/02/2010. Disponível em: <http://www.stj.jus.br>. Acesso em: 25 out. 2010.

BRASIL. Superior Tribunal de Justiça. Recurso Especial n. 622724/SC. Relator: Ministro Felix Fischer. J. em 18/11/2004. Disponível em: <http://www.stj.jus.br>. Acesso em: 25 out. 2010.

BRASIL. Superior Tribunal de Justiça. Recurso Especial n. 62355/RS. Relator: Ministro Adhemar Maciel. J. em 13/06/1995. Disponível em: <http://www.stj.jus.br>. Acesso em: 25 out. 2010.

BRASIL. Superior Tribunal de Justiça. Recurso Especial n. 633250/AM. Relator: Ministra Laurita Vaz. J. em 21/11/2006. Disponível em: <http://www.stj.jus.br>. Acesso em: 25 out. 2010 .

BRASIL. Superior Tribunal de Justiça. Recurso Especial n. 641754/PB. Relator: Ministro Castro Meira. J. em 10/08/2004. Disponível em: <http://www.stj.jus.br>. Acesso em: 25 out. 2010. 
BRASIL. Superior Tribunal de Justiça. Recurso Especial n. 646869/SP. Relator: Ministro José Arnaldo da Fonseca. J. em 18/11/2004. Disponível em: <http://www.stj.jus.br>. Acesso em: 25 out. 2010.

BRASIL. Superior Tribunal de Justiça. Recurso Especial n. 647493/SC. Relator: Ministro João Otávio de Noronha. J. em 22/05/2007. Disponível em: <http://www.stj.jus.br>. Acesso em: 25 out. 2010.

BRASIL. Superior Tribunal de Justiça. Recurso Especial n. 668470/SC. Relator: Ministro Felix Fischer. J. em 07/12/2004. Disponível em: <http://www.stj.jus.br>. Acesso em: 25 out. 2010.

BRASIL. Superior Tribunal de Justiça. Recurso Especial n. 680007/SC. Relator: Ministro GILSON DIPP. J. em 15/02/2005. Disponível em: <http://www.stj.jus.br>. Acesso em: 25 out. 2010.

BRASIL. Superior Tribunal de Justiça. Recurso Especial n. 693261/SC. Relator: Ministra Laurita Vaz. J. em 19/05/2005. Disponível em: <http://www.stj.jus.br>. Acesso em: 25 out. 2010.

BRASIL. Superior Tribunal de Justiça. Recurso Especial n. 697585/TO. Relator: Ministro Gilson Dipp. J. em 22/03/2005. Disponível em: <http://www.stj.jus.br>. Acesso em: 25 out. 2010.

BRASIL. Superior Tribunal de Justiça. Recurso Especial n. 730034/PA. Relator: Ministro Mauro Campbell Marques. J. em 09/03/2010. Disponível em: <http://www.stj.jus.br>. Acesso em: 25 out. 2010.

BRASIL. Superior Tribunal de Justiça. Recurso Especial n. 746765/PA. Relator: Ministra Laurita Vaz. J. em 17/11/2005. Disponível em: <http://www.stj.jus.br>. Acesso em: 25 out. 2010 .

BRASIL. Superior Tribunal de Justiça. Recurso Especial n. 747033/SC. Relator: Ministro Gilson Dipp. J. em 06/12/2005. Disponível em: <http://www.stj.jus.br>. Acesso em: 25 out. 2010.

BRASIL. Superior Tribunal de Justiça. Recurso Especial n. 764054/SP. Relator: Ministro Gilson Dipp. J. em 02/02/2006. Disponível em: <http://www.stj.jus.br>. Acesso em: 25 out. 2010.

BRASIL. Superior Tribunal de Justiça. Recurso Especial n. 779951/DF. Relator: Ministra Laurita Vaz. J. em 15/02/2007. Disponível em: <http://www.stj.jus.br>. Acesso em: 25 out. 2010 .

BRASIL. Superior Tribunal de Justiça. Recurso Especial n. 783652/SP. Relator: Ministro Felix Fischer. J. em 16/05/2006. Disponível em: <http://www.stj.jus.br>. Acesso em: 25 out. 2010.

BRASIL. Superior Tribunal de Justiça. Recurso Especial n. 789481/MT. Relator: Ministro Herman Benjamin. J. em 27/11/2007. Disponível em: <http://www.stj.jus.br>. Acesso em: 25 out. 2010.

BRASIL. Superior Tribunal de Justiça. Recurso Especial n. 800817/SC. Relator: Ministro Celso Limongi (Desembargador Convocado do TJ/SP). J. em 04/02/2010. Disponível em: $<$ http://www.stj.jus.br>. Acesso em: 25 out. 2010. 
BRASIL. Superior Tribunal de Justiça. Recurso Especial n. 802060/RS. Relator: Ministro Luiz Fux. J. em 17/12/2009. Disponível em: <http://www.stj.jus.br>. Acesso em: 25 out. 2010.

BRASIL. Superior Tribunal de Justiça. Recurso Especial n. 804497/SC. Relator: Ministro Paulo Gallotti. J. em 29/06/2009. Disponível em: <http://www.stj.jus.br>. Acesso em: 25 out. 2010.

BRASIL. Superior Tribunal de Justiça. Recurso Especial n. 804918/TO. Relator: Ministra Laurita Vaz. J. em 03/04/2008. Disponível em: <http://www.stj.jus.br>. Acesso em: 25 out. 2010 .

BRASIL. Superior Tribunal de Justiça. Recurso Especial n. 815071/BA. Relator: Ministro Gilson Dipp. J. em 23/05/2006. Disponível em: <http://www.stj.jus.br>. Acesso em: 25 out. 2010.

BRASIL. Superior Tribunal de Justiça. Recurso Especial n. 815079/SP. Relator: Ministro Felix Fischer. J. em 15/03/2007. Disponível em: <http://www.stj.jus.br>. Acesso em: 25 out. 2010.

BRASIL. Superior Tribunal de Justiça. Recurso Especial n. 826409/PB. Relator: Ministro Francisco Falcão. J. em 02/05/2006. Disponível em: <http://www.stj.jus.br>. Acesso em: 25 out. 2010.

BRASIL. Superior Tribunal de Justiça. Recurso Especial n. 838846/MT. Relator: Ministro Gilson Dipp. J. em 17/08/2006. Disponível em: <http://www.stj.jus.br>. Acesso em: 25 out. 2010.

BRASIL. Superior Tribunal de Justiça. Recurso Especial n. 846453/SC. Relator: Ministro Gilson Dipp. J. em 19/04/2007. Disponível em: <http://www.stj.jus.br>. Acesso em: 25 out. 2010.

BRASIL. Superior Tribunal de Justiça. Recurso Especial n. 847476/SC. Relator: Ministro Paulo Gallotti. J. em 08/04/2008. Disponível em: <http://www.stj.jus.br>. Acesso em: 25 out. 2010.

BRASIL. Superior Tribunal de Justiça. Recurso Especial n. 849423/SP. Relator: Ministro Gilson Dipp. J. em 19/09/2006. Disponível em: <http://www.stj.jus.br>. Acesso em: 25 out. 2010.

BRASIL. Superior Tribunal de Justiça. Recurso Especial n. 850110/SP. Relatora: Ministra Laurita Vaz. J. em 22/04/2008. Disponível em: <http://www.stj.jus.br>. Acesso em: 25 out. 2010 .

BRASIL. Superior Tribunal de Justiça. Recurso Especial n. 859914/PB. Relator: Ministro Castro Meira. J. em 25/05/2010. Disponível em: <http://www.stj.jus.br>. Acesso em: 25 out. 2010.

BRASIL. Superior Tribunal de Justiça. Recurso Especial n. 860615/DF. Relatora: Ministra Eliana Calmon. J. em 24/10/2006. Disponível em: <http://www.stj.jus.br>. Acesso em: 25 out. 2010.

BRASIL. Superior Tribunal de Justiça. Recurso Especial n. 867938/PR. Relator: Ministro Felix Fischer. J. em 22/05/2007. Disponível em: <http://www.stj.jus.br>. Acesso em: 25 out. 2010. 
BRASIL. Superior Tribunal de Justiça. Recurso Especial n. 873655/PR. Relator: Ministro Luiz Fux. J. em 19/08/2008. Disponível em: <http://www.stj.jus.br>. Acesso em: 25 out. 2010.

BRASIL. Superior Tribunal de Justiça. Recurso Especial n. 876915/RS. Relator: Ministro Felix Fischer. J. em 07/12/2006. Disponível em: <http://www.stj.jus.br>. Acesso em: 25 out. 2010.

BRASIL. Superior Tribunal de Justiça. Recurso Especial n. 878939/MT. Relator: Ministro Herman Benjamin. J. em 13/11/2007. Disponível em: <http://www.stj.jus.br>. Acesso em: 25 out. 2010.

BRASIL. Superior Tribunal de Justiça. Recurso Especial n. 881944/SP. Relator: Ministro Felix Fischer. J. em 03/02/2009. Disponível em: <http://www.stj.jus.br>. Acesso em: 25 out. 2010.

BRASIL. Superior Tribunal de Justiça. Recurso Especial n. 886137/MG. Relator: Ministro Humberto Martins. J. em 15/04/2008. Disponível em: <http://www.stj.jus.br>. Acesso em: 25 out. 2010.

BRASIL. Superior Tribunal de Justiça. Recurso Especial n. 889528/SC. Relator: Ministro Felix Fischer. J. em 17/04/2007. Disponível em: <http://www.stj.jus.br>. Acesso em: 25 out. 2010.

BRASIL. Superior Tribunal de Justiça. Recurso Especial n. 895530/PR. Relator: Ministro Luiz Fux. J. em 18/11/2008. Disponível em: <http://www.stj.jus.br>. Acesso em: 25 out. 2010.

BRASIL. Superior Tribunal de Justiça. Recurso Especial n. 896312/PA. Relator: Ministro Arnaldo Esteves Lima. J. em 16/08/2007. Disponível em: <http://www.stj.jus.br>. Acesso em: 25 out. 2010.

BRASIL. Superior Tribunal de Justiça. Recurso Especial n. 897426/SP. Relatora: Ministra Laurita Vaz. J. em 27/03/2008. Disponível em: <http://www.stj.jus.br>. Acesso em: 25 out. 2010.

BRASIL. Superior Tribunal de Justiça. Recurso Especial n. 905484/RO. Relator: Ministro Arnaldo Esteves Lima. J. em 04/02/2010. Disponível em: <http://www.stj.jus.br>. Acesso em: 25 out. 2010 .

BRASIL. Superior Tribunal de Justiça. Recurso Especial n. 905783/RO. Relator: Ministro Herman Benjamin. J. em 07/02/2008. Disponível em: <http://www.stj.jus.br>. Acesso em: 25 out. 2010 .

BRASIL. Superior Tribunal de Justiça. Recurso Especial n. 9120/AM. Relator: Ministro Edson Vidigal. J. em 05/06/1991. Disponível em: <http://www.stj.jus.br>. Acesso em: 25 out. 2010.

BRASIL. Superior Tribunal de Justiça. Recurso Especial n. 918025/SP. Relator: Ministro Felix Fischer. J. em 09/10/2007. Disponível em: $<$ http://www.stj.jus.br $>$. Acesso em: 25 out. 2010.

BRASIL. Superior Tribunal de Justiça. Recurso Especial n. 922588/BA. Relator: Ministra Laurita Vaz. J. em 27/09/2007. Disponível em: <http://www.stj.jus.br>. Acesso em: 25 out. 2010. 
BRASIL. Superior Tribunal de Justiça. Recurso Especial n. 930781/DF. Relator: Ministro Arnaldo Esteves Lima. J. em 18/08/2009. Disponível em: <http://www.stj.jus.br>. Acesso em: 25 out. 2010.

BRASIL. Superior Tribunal de Justiça. Recurso Especial n. 933356/MG. Relator: Ministra Maria Thereza de Assis Moura. J. em 18/12/2007. Disponível em: <http://www.stj.jus.br>. Acesso em: 25 out. 2010.

BRASIL. Superior Tribunal de Justiça. Recurso Especial n. 942326/MS. Relator: Ministro Arnaldo Esteves Lima. J. em 10/09/2009. Disponível em: <http://www.stj.jus.br>. Acesso em: 25 out. 2010.

BRASIL. Superior Tribunal de Justiça. Recurso Especial n. 969160/RJ. Relator: Ministro Arnaldo Esteves Lima. J. em 06/08/2009. Disponível em: <http://www.stj.jus.br>. Acesso em: 25 out. 2010 .

BRASIL. Superior Tribunal de Justiça. Recurso Especial n. 972979/MG. Relator: Ministro Humberto Martins. J. em 04/03/2008. Disponível em: <http://www.stj.jus.br>. Acesso em: 25 out. 2010.

BRASIL. Superior Tribunal de Justiça. Recurso Especial n. 980463/PR. Relator: Ministro Arnaldo Esteves Lima. J. em 23/06/2009. Disponível em: <http://www.stj.jus.br>. Acesso em: 25 out. 2010.

BRASIL. Superior Tribunal de Justiça. Recurso Especial n. 985174/MT. Relatora: Ministra Denise Arruda. J. em 05/02/2009. Disponível em: <http://www.stj.jus.br>. Acesso em: 25 out. 2010.

BRASIL. Superior Tribunal de Justiça. Recurso Especial n. 989089/SC. Relator: Ministro Arnaldo Esteves Lima. J. em 18/08/2009. Disponível em: <http://www.stj.jus.br>. Acesso em: 25 out. 2010.

BRASIL. Superior Tribunal de Justiça. Recurso Especial n. 991860/RS. Relator: Ministro Jorge Mussi. J. em 04/09/2008. Disponível em: <http://www.stj.jus.br>. Acesso em: 25 out. 2010.

BRASIL. Superior Tribunal de Justiça. REsp n. 610114/RN. Relator: Ministro Gilson Dipp. J. em 17/11/2005. Disponível em: <http://www.stj.jus.br>. Acesso em: 25 out. 2010.

BRASIL. Supremo Tribunal Federal. Ação Direta de Inconstitucionalidade n. 2.714-0/DF. Relator: Ministro Maurício Corrêa. J. em 13/03/2003. Disponível em: $<$ http://www.stf.jus.br>. Acesso em: 25 out. 2010.

BRASIL. Supremo Tribunal Federal. Ação Direta de Inconstitucionalidade n. 2.083-8/DF. Relator: Ministro Moreira Alves. J. em 03/08/2000. Disponível em: $<$ http://www.stf.jus.br>. Acesso em: 25 out. 2010.

BRASIL. Supremo Tribunal Federal. Ação Penal n. 439-1/SP. Relator: Ministro Marco Aurélio. Revisor: Ministro Gilmar Mendes. J. em 12/06/2008. Disponível em: $<$ http://www.stf.jus.br>. Acesso em: 25 out. 2010.

BRASIL. Supremo Tribunal Federal. Agravo de Instrumento n. 710.392/MG. Relator: Ministro Joaquim Barbosa. Pendente de julgamento. Disponível em: $<$ http://www.stf.jus.br>. Acesso em: 25 out. 2010.

BRASIL. Supremo Tribunal Federal. Agravo Regimental em Recurso Extraordinário n. 593729/SP. Relator: Ministro Cezar Peluso. J. em 25/11/2008. Disponível em: $<$ http://www.stf.jus.br>. Acesso em: 25 out. 2010. 
BRASIL. Supremo Tribunal Federal. Agravo Regimental na Reclamação n. 6.449/RS. Relator: Ministro Eros Grau. J. em 25/11/2009. Disponível em: <http://www.stf.jus.br>. Acesso em: 25 out. 2010.

BRASIL. Supremo Tribunal Federal. Habeas Corpus n. 100.230/SP. Relator: Ministro Ayres Britto. J. em 17/08/2010. Disponível em: <http://www.stf.jus.br>. Acesso em: 25 out. 2010.

BRASIL. Supremo Tribunal Federal. Habeas Corpus n. 101.851/MT. Relator: Ministro Dias Toffoli. J. em 03/08/2010. Disponível em: <http://www.stf.jus.br>. Acesso em: 25 out. 2010.

BRASIL. Supremo Tribunal Federal. Habeas Corpus n. 103.033/SC. Relator: Ministro Ricardo Lewandowski. J. em 01/06/2010. Disponível em: <http://www.stf.jus.br>. Acesso em: 25 out. 2010 .

BRASIL. Supremo Tribunal Federal. Habeas Corpus n. 32.460. Relator: Ministro Rocha Lagoa. J. em 20/05/1953. Disponível em: <http://www.stf.jus.br>. Acesso em: 25 out. 2010 .

BRASIL. Supremo Tribunal Federal. Habeas Corpus n. 81.916-8/PA. Relator: Ministro Gilmar Mendes. J. em 17/09/2002. Disponível em: <http://www.stf.jus.br>. Acesso em: 25 out. 2010.

BRASIL. Supremo Tribunal Federal. Habeas Corpus n. 83.163-0/SP. Relator originário: Ministro Sepúlveda Pertence. Relator para o acórdão: Ministro Joaquim Barbosa J. em 16/04/2009. Disponível em: <http://www.stf.jus.br>. Acesso em: 25 out. 2010.

BRASIL. Supremo Tribunal Federal. Habeas Corpus n. 83.301-2/RS. Relator: Ministro Marco Auréliio. J. em 16/12/2003. Disponível em: <http://www.stf.jus.br>. Acesso em: 25 out. 2010.

BRASIL. Supremo Tribunal Federal. Habeas Corpus n. 83.554-6/PR. Relator: Ministro Gilmar Mendes. J. em 16/08/2005. Disponível em: <http://www.stf.jus.br>. Acesso em: 25 out. 2010.

BRASIL. Supremo Tribunal Federal. Habeas Corpus n. 84.821-4/MG. Relator: Ministro Joaquim Barbosa. J. em 23/08/2005. Disponível em: <http://www.stf.jus.br $>$. Acesso em: 25 out. 2010.

BRASIL. Supremo Tribunal Federal. Habeas Corpus n. 85.066-9/GO. Relator: Ministro Carlos Velloso. J. em 26/04/2005. Disponível em: <http://www.stf.jus.br>. Acesso em: 25 out. 2010.

BRASIL. Supremo Tribunal Federal. Habeas Corpus n. 85.190-8/SC. Relator: Ministro Joaquim Barbosa. J. em 08/11/2005. Disponível em: <http://www.stf.jus.br>. Acesso em: 25 out. 2010.

BRASIL. Supremo Tribunal Federal. Habeas Corpus n. 85.335-8/PA. Relator: Ministro Gilmar Mendes. J. em 13/09/2005. Disponível em: <http://www.stf.jus.br>. Acesso em: 25 out. 2010.

BRASIL. Supremo Tribunal Federal. Habeas Corpus n. 85.496-6/SC. Relator: Ministro Ricardo Lewandowski. J. em 22/08/2006. Disponível em: <http://www.stf.jus.br>. Acesso em: 25 out. 2010. 
BRASIL. Supremo Tribunal Federal. Habeas Corpus n. 85.747-7/SP. Relator: Ministro Marco Aurélio. J. em 21/06/2005. Disponível em: <http://www.stf.jus.br>. Acesso em: 25 out. 2010.

BRASIL. Supremo Tribunal Federal. Habeas Corpus n. 85471/RO. Relator: Ministro Min. Eros Grau. J. em 29/03/2005. Disponível em: <http://www.stf.jus.br>. Acesso em: 25 out. 2010 .

BRASIL. Supremo Tribunal Federal. Habeas Corpus n. 86.249-7/SP. Relator: Ministro Carlos Britto. J. em 29/11/2005. Disponível em: <http://www.stf.jus.br>. Acesso em: 25 out. 2010.

BRASIL. Supremo Tribunal Federal. Habeas Corpus n. 86.361-2/SP. Relator: Ministro Menezes Direito. J. em 16/10/2007. Disponível em: <http://www.stf.jus.br>. Acesso em: 25 out. 2010.

BRASIL. Supremo Tribunal Federal. Habeas Corpus n. 86.645-0/SP. Relator: Ministro Gilmar Mendes. J. em 28/03/2006. Disponível em: <http://www.stf.jus.br>. Acesso em: 25 out. 2010.

BRASIL. Supremo Tribunal Federal. Habeas Corpus n. 87.577-7/MT. Relator: Ministro Gilmar Mendes. J. em 06/06/2006. Disponível em: <http://www.stf.jus.br>. Acesso em: 25 out. 2010.

BRASIL. Supremo Tribunal Federal. Habeas Corpus n. 87.945-4/MT. Relator: Ministro Gilmar Mendes. J. em 06/06/2006. Disponível em: <http://www.stf.jus.br>. Acesso em: 25 out. 2010.

BRASIL. Supremo Tribunal Federal. Habeas Corpus n. 88.392-3/MT. Relator: Ministro Gilmar Mendes. J. em 06/06/2006. Disponível em: <http://www.stf.jus.br>. Acesso em: 25 out. 2010.

BRASIL. Supremo Tribunal Federal. Habeas Corpus n. 89.735-5/SP. Relator: Ministro Menezes Direito. J. em 20/11/2007. Disponível em: <http://www.stf.jus.br>. Acesso em: 25 out. 2010.

BRASIL. Supremo Tribunal Federal. Habeas Corpus n. 89.878/SP. Relator: Ministro Eros Grau. J. em 20/04/2010. Disponível em: <http://www.stf.jus.br>. Acesso em: 25 out. 2010.

BRASIL. Supremo Tribunal Federal. Habeas Corpus n. 90.023-2/SP. Relator: Ministro Menezes Direito. J. em 06/11/2007. Disponível em: <http://www.stf.jus.br>. Acesso em: 25 out. 2010.

BRASIL. Supremo Tribunal Federal. Habeas Corpus n. 90.326-6/RS. Relator: Ministro Menezes Direito. J. em 11/12/2007. Disponível em: <http://www.stf.jus.br>. Acesso em: 25 out. 2010.

BRASIL. Supremo Tribunal Federal. Habeas Corpus n. 91.005-0/DF. Relator: Ministro Carlos Britto. J. em 24/04/2007. Disponível em: <http://www.stf.jus.br>. Acesso em: 25 out. 2010.

BRASIL. Supremo Tribunal Federal. Habeas Corpus n. 92.308-9/RS. Relator: Ministro Marco Aurélio. J. em 04/11/2008. Disponível em: <http://www.stf.jus.br>. Acesso em: 25 out. 2010.

BRASIL. Supremo Tribunal Federal. Habeas Corpus n. 92.921-4/BA. Relator: Ministro Ricardo Lewandowski. J. em 19/08/2008. Disponível em: <http://www.stf.jus.br>. Acesso em: 25 out. 2010. 
BRASIL. Supremo Tribunal Federal. Habeas Corpus n. 93.339-4/SC. Relatora: Ministra Cármen Lúcia. J. em 18/03/2008. Disponível em: <http://www.stf.jus.br>. Acesso em: 25 out. 2010.

BRASIL. Supremo Tribunal Federal. Habeas Corpus n. 93.442-1/SP. Relator: Ministro Menezes Direito. J. em 25/03/2008. Disponível em: <http://www.stf.jus.br>. Acesso em: 25 out. 2010.

BRASIL. Supremo Tribunal Federal. Habeas Corpus n. 94.842-1/RS. Relator: Ministro Eros Grau. J. em 26/05/2009. Disponível em: <http://www.stf.jus.br>. Acesso em: 25 out. 2010 .

BRASIL. Supremo Tribunal Federal. Habeas Corpus n. 97.484-8/SP. Relatora: Ministra Ellen Gracie. J. em 23/06/2009. Disponível em: <http://www.stf.jus.br>. Acesso em: 25 out. 2010.

BRASIL. Supremo Tribunal Federal. HC n. 85.747-7/SP. Relator: Ministro Marco Aurélio. J. em 21/06/2005. Disponível em: <http://www.stf.jus.br>. Acesso em: 25 out. 2010.

BRASIL. Supremo Tribunal Federal. Inquérito n. 1.423-2/MG. Relator: Ministro Sepúlveda Pertence. J. em 18/11/2004. Disponível em: <http://www.stf.jus.br>. Acesso em: 25 out. 2010 .

BRASIL. Supremo Tribunal Federal. Inquérito n. 2.721/DF. Relator: Ministro Joaquim Barbosa. J. em 08/10/2009. Disponível em: <http://www.stf.jus.br>. Acesso em: 25 out. 2010.

BRASIL. Supremo Tribunal Federal. Medida Cautelar em Ação Direta de Inconstitucionalidade n. 2.622-4/RO. Relator: Ministro Sydney Sanches. J. em 08/08/2002. Disponível em: <http://www.stf.jus.br>. Acesso em: 25 out. 2010.

BRASIL. Supremo Tribunal Federal. Questão de Ordem em Recurso Extraordinário n. 430105/RJ. Relator: Ministro Sepúlveda Pertence. J. em 13/02/2007. Disponível em: $<$ http://www.stf.jus.br>. Acesso em: 25 out. 2010.

BRASIL. Supremo Tribunal Federal. Recurso Extraordinário n. 300244/SC. Relator: Ministro Moreira Alves. J. em 20/11/2001. Disponível em: $<$ http://www.stf.jus.br>. Acesso em: 25 out. 2010.

BRASIL. Supremo Tribunal Federal. Recurso Extraordinário n. 349184/TO. Relator: Ministro Moreira Alves. J. em 03/12/2002. Disponível em: $<$ http://www.stf.jus.br>. Acesso em: 25 out. 2010.

BRASIL. Supremo Tribunal Federal. Recurso Extraordinário n. 349186/TO. Relator: Ministro Ilmar Galvão. J. em 22/10/2002. Disponível em: <http://www.stf.jus.br>. Acesso em: 25 out. 2010.

BRASIL. Supremo Tribunal Federal. Recurso Extraordinário n. 349189/TO. Relator: Ministro Moreira Alves. J. em 17/09/2002. Disponível em: $<$ http://www.stf.jus.br>. Acesso em: 25 out. 2010.

BRASIL. Supremo Tribunal Federal. Recurso Extraordinário n. 349191/TO. Relator: Ministro Ilmar Galvão. J. em 17/12/2002. Disponível em: <http://www.stf.jus.br>. Acesso em: 25 out. 2010.

BRASIL. Supremo Tribunal Federal. Recurso Extraordinário n. 349196/TO. Relator: Ministro Moreira Alves. J. em 17/09/2002. Disponível em: $<$ http://www.stf.jus.br>. Acesso em: 25 out. 2010. 
BRASIL. Supremo Tribunal Federal. Recurso Extraordinário n. 349198/TO. Relator: Ministro Ilmar Galvão. J. em 17/12/2002. Disponível em: <http://www.stf.jus.br>. Acesso em: 25 out. 2010.

BRASIL. Supremo Tribunal Federal. Recurso Extraordinário n. 464893/GO. Relator: Ministro Joaquim Barbosa. J. em 20/05/2008. Disponível em: $<$ http://www.stf.jus.br>. Acesso em: 25 out. 2010.

BRASIL. Supremo Tribunal Federal. Recurso Extraordinário n. 498261/SP. Relatora: Ministra. J. Ellen Gracie. J. em 17/06/2008. Disponível em: $<$ http://www.stf.jus.br>. Acesso em: 25 out. 2010.

BRASIL. Supremo Tribunal Federal. Recurso Extraordinário n. 499017/SP. Relatora: Ministra Ellen Gracie. J. em 17/06/2008. Disponível em: <http://www.stf.jus.br>. Acesso em: 25 out. 2010.

BRASIL. Supremo Tribunal Federal. Recurso Extraordinário n. 502372/SP. Relatora: Ministra Ellen Gracie. J. em 17/06/2008. Disponível em: <http://www.stf.jus.br>. Acesso em: 25 out. 2010.

BRASIL. Supremo Tribunal Federal. Recurso Extraordinário n. 502915/SP. Relator: Ministro Sepúlveda Pertence. J. em 13/02/2007. Disponível em: $<$ http://www.stf.jus.br>. Acesso em: 25 out. 2010.

BRASIL. Supremo Tribunal Federal. Recurso Extraordinário n. 502928/SP. Relatora: Ministra Ellen Gracie. J. em 17/06/2008. Disponível em: <http://www.stf.jus.br>. Acesso em: 25 out. 2010.

BRASIL. Supremo Tribunal Federal. Recurso Extraordinário n. 540597/MT. Relatora: Ministra Ellen Gracie. J. em 17/06/2008. Disponível em: <http://www.stf.jus.br>. Acesso em: 25 out. 2010.

BRASIL. Supremo Tribunal Federal. Recurso Extraordinário n. 541627/PA. Relatora: Ministra. J. Ellen Gracie. em 14/10/2008. Disponível em: $<$ http://www.stf.jus.br>. Acesso em: 25 out. 2010.

BRASIL. Supremo Tribunal Federal. Recurso Ordinário em Habeas Corpus n. 97.5984/SC. Relatora: Ministra Ellen Gracie. J. em 04/08/2009. Disponível em: $<$ http://www.stf.jus.br>. Acesso em: 25 out. 2010.

BRASIL. Supremo Tribunal Federal. Recurso Ordinário em Habeas Corpus n. 85.2149/MG. Relator: Ministro Sepúlveda Pertence. J. em 17/05/2005. Disponível em: $<$ http://www.stf.jus.br>. Acesso em: 25 out. 2010.

BRASIL. Supremo Tribunal Federal. Recurso Ordinário em Habeas Corpus n. 83.4370/SP. Relator: Ministro Joaquim Barbosa. J. em 10/02/2004. Disponível em: $<$ http://www.stf.jus.br>. Acesso em: 25 out. 2010.

BRASIL. Supremo Tribunal Federal. Recurso Ordinário em Habeas Corpus n. 83.0714/SC. Relator: Ministro Gilmar Mendes. J. em 09/12/2003. Disponível em: $<$ http://www.stf.jus.br>. Acesso em: 25 out. 2010.

PARANÁ. Tribunal de Justiça do Estado do Paraná. Apelação Criminal n. 279571-5. Relator: Desembargador Laertes Ferreira Gomes. J. em 21/07/2005. Disponível em: < http://www.tjpr.jus.br/ >. Acesso em: 25 out. 2010. 
RIO GRANDE DO SUL. Tribunal Regional Federal da $4^{\mathrm{a}}$ Região. Apelação Criminal n. 2001.72.00.00.7080-3. Relator: Desembargador Federal Luiz Fernando Wowk Penteado. J. em 11/02/2004. Disponível em: <http://www.trf4.jus.br>. Acesso em: 25 out. 2010.

RONDÔNIA. Tribunal de Justiça de Rondônia. Apelação Criminal n. 100668703.2004.822.0501. Relatora: Desembargadora Zelite Andrade Carneiro. J. em 27/04/2006. Disponível em $<$ http://www.tjro.jus.br>. Acesso em 5.12.2010:

SANTA CATARINA. Tribunal de Justiça de Santa Catarina. Apelação Criminal n. 2006.00.2010-3. Relator: Desembargador Irineu João da Silva. J. em 21/02/2006. Disponível em: < http://www.tj.sc.gov.br/ >. Acesso em: 25 out. 2010.

SANTA CATARINA. Tribunal de Justiça de Santa Catarina. Recurso Criminal em Apelação Criminal n. 2006.030339-9. Relator: Desembargador Sérgio Paladino. J. em 27/02/2007. Disponível em <http://www.tj.sc.gov.br>. Acesso em 05.12.2010.

SANTA CATARINA. Vara ambiental federal de Florianópolis. Ação Penal n. 2001.72.00.007080-3. Juiz: Julio Guilherme Berezoski Schattschneider. J. em 05/09/2002. Disponível em: <http://www.trf4.jus.br>. Acesso em: 25 out. 2010.

SÃO PAULO. Tribunal de Justiça de São Paulo. Apelação Criminal n. 990.10.303524-0. Relator: Desembargador Ivan Marques. Pendente de julgamento. Disponível em: $<$ https://www.tjsp.jus.br>. Acesso em: 25 out. 2010.

SÃO PAULO. Tribunal Regional Federal da $3^{\mathrm{a}}$ Região. Apelação Criminal n. 2000.61.10.000124-6. Relator: Desembargador Federal Vesna Kolmar. Pendente de julgamento. Disponível em $<$ http://www.trf3.jus.br>. Acesso em 02.12.2010. 